\author{
UNIVERSIDADE DE SÃO PAULO \\ FACULDADE DE ARQUITETURA E URBANISMO
}

ANDRESSA CELLI

Evolução Urbana de Sorocaba

SÃO PAULO

2012 
ANDRESSA CELLI

\section{Evolução Urbana de Sorocaba}

Dissertação apresentada à Faculdade de Arquitetura e Urbanismo da Universidade de São Paulo para obtenção do título de Mestre em Arquitetura e Urbanismo.

Área de Concentração: Planejamento Urbano e Regional.

Orientadora: Profa. Dra. Marly Namur. 
AUTORIZO A REPRODUÇÃO E DIVULGAÇÃO TOTAL OU PARCIAL DESTE TRABALHO, POR QUALQUER MEIO CONVENCIONAL OU ELETRÔNICO, PARA FINS DE ESTUDO E PESQUISA, DESDE QUE CITADA A FONTE.

E-MAIL AUTORA: andressacelli@gmail.com

\begin{tabular}{|l} 
Celli, Andressa \\
Evolução urbana de Sorocaba / Andressa Celli. --São \\
Paulo, 2012. \\
130 p. : il. \\
Dissertação (Mestrado - Área de Concentração: Planejamento \\
Urbano Regional) - FAUUSP. \\
Orientadora: Marly Namur \\
1.Estruturas urbanas - Sorocaba(SP) 2.Ocupação urbana \\
3.Evolução urbana 4.Sistemas viário urbano I.Título \\
CDU 711.41
\end{tabular}


Dedicatória

A meus queridos pais e irmã, pela força de sempre... 


\section{Folha de Aprovação}

Andressa Celli

Dissertação apresentada à Faculdade de Arquitetura e Urbanismo da Universidade de São Paulo para obtenção do título de Mestre em Arquitetura e Urbanismo.

Área de Concentração: Planejamento Urbano e Regional.

Aprovada em:

Banca examinadora

Profa. Dra. Marly Namur - orientadora

Instituição: Universidade de São Paulo (USP)

Assinatura:

Prof. Dr.

Instituição:

Assinatura:

Prof. Dr.

Instituição:

Assinatura: 


\section{Agradecimentos}

À minha orientadora, Profa. Dra. Marly Namur, pelo incentivo e oportunidade.

Ao Prof. Dr. José Luiz Caruso Ronca e a Profa. Dra. Angélica Aparecida Tanus Benatti Alvim, pelas sugestões dadas no exame de qualificação.

Aos professores que muito me ensinaram ao longo do curso de mestrado.

Aos funcionários do Setor de Pós-Graduação da FAU-USP, pela atenção prestada do início ao fim do mestrado.

À Faculdade de Arquitetura e Urbanismo da Universidade de São Paulo, pela oportunidade de realização desse trabalho.

Aos funcionários da Prefeitura Municipal de Sorocaba, do Museu Ferroviário de Sorocaba, do Museu Histórico Sorocabano e do Museu Republicano que colaboraram com o empréstimo de materiais para a análise de dados.

À ACEC, pelo apoio e compreensão. 


\section{Resumo}

CELLI, A. Evolução Urbana de Sorocaba. 2012. 130p. f. Dissertação (Mestrado) - Faculdade de Arquitetura da Universidade de São Paulo, São Paulo, 2012.

Esse trabalho tem como objetivo compreender como as mudanças socioeconômicas geraram transformações no sistema viário - caminhos, ferrovia, rodovias - e induziram a ocupação urbana - indústrias, loteamentos, condomínios - da cidade de Sorocaba em diferentes períodos - desde a sua fundação em 1661 até o ano de 2000. A partir de características socioeconômicas regionais e urbanas, descrevemos e analisamos o processo de evolução urbana de Sorocaba com o auxílio de croquis-síntese que ilustram o seu crescimento urbano.

Palavras-Chave: Estrutura Urbana, Evolução Urbana, Ocupação Urbana, Viário Urbano. 


\section{Abstract}

CELLI, M. Sorocaba's urban development. 2012. 130p. f. Master's thesis - Faculdade de Arquitetura da Universidade de São Paulo, São Paulo, 2012.

This study aims to understand how the socioeconomic changes have brought out modifications in the road system - paths, railways, roads - and influenced the urban occupation -industries, subdivisions and condominiums - of the city of Sorocaba indifferent periods - since its foundation in 1661 until the year 2000. Taking into account urban and regional socioeconomic characteristics, this work describes and analyzes the process of Sorocaba's urban development based on sketches that illustrate its urban growth.

Keywords: Urban Structure, Urban Development, Urban Occupation, Urban Road System. 


\section{Lista de Croquis}

Croqui 1. Croqui de localização regional de Sorocaba ......................................................... 15

Croqui 2. Croqui de caracterização topográfica e hídrica regional ..................................16

Croqui 3. Croqui dos principais rios e núcleos urbanos da região de Sorocaba .............. 17

Croqui 4. Croqui das Regiões Administrativas do Estado de São Paulo ............................18

Croqui 5. Croqui da Região de Governo de Sorocaba ...................................................... 20

Croqui 6. Croqui do Sistema Viário do Estado de São Paulo ............................................... 21

Croqui 7. Croqui Político e do Sistema Viário Regional de Sorocaba .................................22

Croqui 8. Croqui do Peabiru na América do Sul ................................................................. 24

Croqui 9. Croqui do Peabiru no Estado de São Paulo .........................................................25

Croqui 10. Croqui da Rota para o Oeste e Vilas fundadas por bandeirantes em seu entorno

Croqui 11. Croqui de sobreposição das rotas do Peabiru e das rotas principais dos

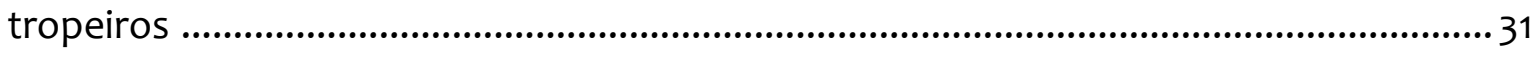

Croqui 12. Croqui da rede ferroviária do Estado de São Paulo .......................................... 36

Croqui 13. Croqui da rede rodoviária do Estado de São Paulo ......................................... 39

Croqui 14. Croqui da Ocupação Indígena e dos Ramais do Peabiru em Sorocaba .......... 43

Croqui 15. Croqui da Ocupação Indígena e dos Ramais do Peabiru, sobreposto ao Viário

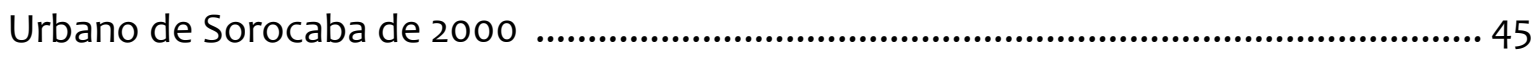

Croqui 16. Croqui Viário e Ocupação Urbana de 1661 ..........................................................51

Croqui 17. Croqui Regional e Urbano de 1661..................................................................52

Croqui 18. Croqui Viário e Ocupação Urbana de 1769 ........................................................5 56

Croqui 19. Croqui Regional e Urbano de 1769 .....................................................................57

Croqui 20. Croqui Viário e Ocupação Urbana de 1839 ........................................................61

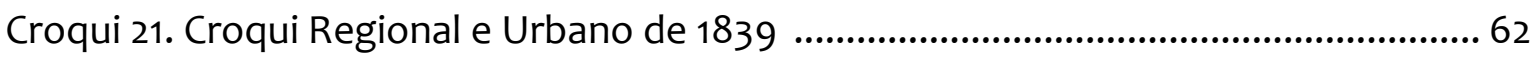

Croqui 22. Croqui Viário e Ocupação Urbana de 1888 .........................................................73

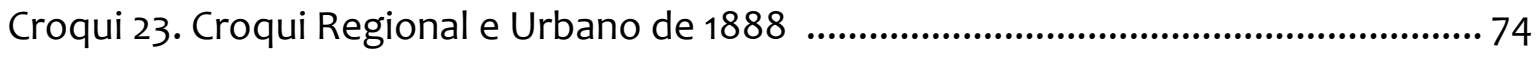

Croqui 24. Croqui Viário e Ocupação Urbana de 1909 .......................................................75

Croqui 25. Croqui Regional e Urbano de 1909 ................................................................... 76

Croqui 26. Croqui Viário e Ocupação Urbana de 1925 ........................................................ 79 
Croqui 27. Croqui Regional e Urbano de 1925 ..................................................................... 80

Croqui 28. Croqui Viário e Ocupação Urbana de 1939 ...................................................... 85

Croqui 29. Croqui Regional e Urbano de 1939 ..................................................................... 86

Croqui 30. Croqui Viário e Ocupação Urbana de 1952 .................................................... 88

Croqui 31. Croqui Regional e Urbano de 1952 ...................................................................89

Croqui 32. Croqui Viário e Ocupação Urbana de 1962 ........................................................99

Croqui 33. Croqui Regional e Urbano de 1962 .................................................................. 95

Croqui 34. Croqui do anel viário implantado pelo PD de 1966 em Sorocaba ..................98 98

Croqui 35. Croqui Viário e Ocupação Urbana de 1981 .......................................................103

Croqui 36. Croqui Regional e Urbano de 1981 ...........................................................104

Croqui 37. Croqui Viário e Ocupação Urbana de 1994 .....................................................108

Croqui 38. Croqui Regional e Urbano de 1994 .................................................................109

Croqui 39. Croqui Viário e Ocupação Urbana de 2000 ......................................................... 111

Croqui 40. Croqui Regional e Urbano de 2000 .................................................................112

Croqui 41. Croqui referente ao período de 1661 a 1839 .................................................... 119

Croqui 42. Croqui referente ao período de 1888 a 1952 .................................................121

Croqui 43. Croqui referente ao período de 1962 a 2000 ................................................ 123

Croqui 44. Croqui referente ao período de 1661 a 2000 .................................................. 125 


\section{Lista de Figuras}

Figura 1. Mapa da Região Administrativa de Sorocaba ..................................................19

Figura 2. Rotas Tropeiras de muares do Sul para Sorocaba ............................................ 28

Figura 3. Área de Influência do Tropeirismo .......................................................................... 33

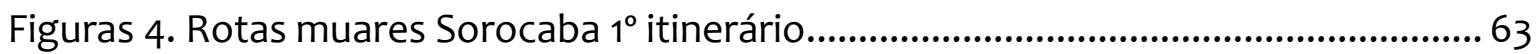

Figuras 5. Rotas muares Sorocaba $2^{\circ}$ itinerário .................................................................63 63

Figuras 6. Rotas muares Sorocaba $3^{\circ}$ itinerário ...............................................................64 64

Figuras 7. Rotas muares Sorocaba $4^{\circ}$ itinerário ............................................................64

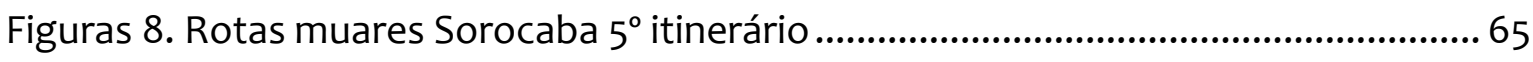

Figuras 9. Rotas muares Sorocaba $6^{\circ}$ itinerário.............................................................6 65

Figura 10. Croquis de 1820 mostrando a influência dos itinerários dos tropeiros no crescimento da malha viária da cidade de Sorocaba .66

Figura 11. Croquis de 1840 mostrando a influência dos itinerários dos tropeiros no crescimento da malha viária da cidade de Sorocaba

Figura 12. Croquis de 1860 mostrando a influência dos itinerários dos tropeiros no crescimento da malha viária da cidade de Sorocaba .........................................................67 67

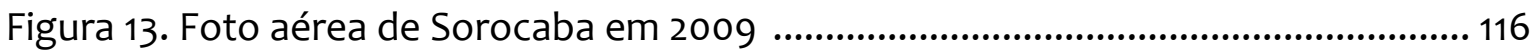




\section{Sumário}

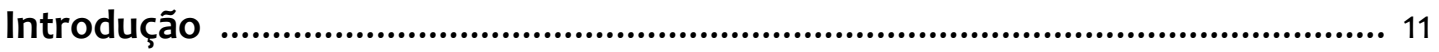

Capítulo 1. Sorocaba: cidade e região

1.1 Localização e situação .............................................................................................. 15

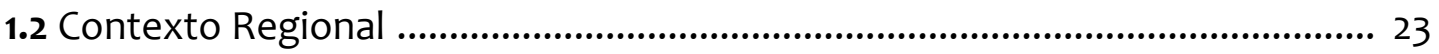

Capítulo 2 Os caminhos como indutores do crescimento urbano de Sorocaba

2.1 Precedentes do povoamento de Sorocaba ...................................................... 42

2.2 Evolução Urbana de 1600 a 1700 ................................................................. 48

2.3 Evolução Urbana de 1700 a 1875 ........................................................................ 54

Capítulo 3 A Ferrovia como indutora do crescimento urbano de Sorocaba

3.1 Evolução Urbana de 1875 a 1930 .......................................................................... 70

3.2 Evolução Urbana de 1930 a 1954 .......................................................................... 83

Capítulo 4 As Rodovias como indutoras do crescimento urbano de Sorocaba

Evolução Urbana de 1954 a 2000 ....................................................................... 92

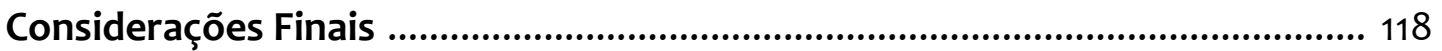

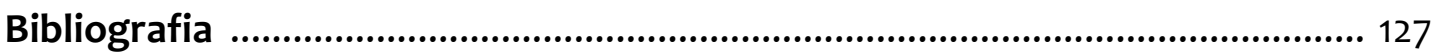




\section{Introdução}

Tendo em vista a necessidade de se compreender mais profundamente alguns aspectos da produção do espaço urbano, apresentamos, nesse trabalho, uma abordagem analítico-descritiva da evolução urbana da cidade de Sorocaba a partir de uma discussão complementada por croquis-síntese que ilustram a estruturação do seu espaço urbano desde a sua fundação em 1661 (Frioli, 2003; Prestes, 2001) até o ano de 2000.

Analisamos o processo de evolução urbana a partir de uma periodização baseada na configuração do sistema viário de Sorocaba. Discutimos como o viário induziu o crescimento urbano de Sorocaba nos seguintes períodos: anterior a 1600 - 1875, referente aos caminhos dos índios, bandeirantes e tropeiros; 1875 - 1954, ao da ferrovia; 1954 - 2000, ao das rodovias.

Estudar a evolução urbana é relevante na medida em que nos auxilia a compreender como se dá a estruturação de um determinado espaço urbano em diferentes períodos. A discussão desse processo é fundamental para que possamos utilizar essa experiência na definição de políticas públicas. Dessa forma, entendemos que esse estudo possa nos ajudar a criar uma legislação mais eficaz no controle do desenvolvimento das cidades, com o objetivo de promover uma boa qualidade ambiental urbana (Campos Filho, 1992).

Podemos dizer, desse modo, que estudamos como as mudanças socioeconômicas determinaram as transformações do sistema viário e induziram a ocupação urbana de Sorocaba. Pretendemos entender como esses elementos da estrutura urbana se articularam e geraram crescimento urbano (Campos Filho, 1992; Castells, 2006; Villaça, 2001).

Analisamos o problema a partir das condicionantes históricas e socioeconômicas regionais estaduais (Cano, 1992; Monbeig, 1984; Reis Filho, 2010; Zimmermann, 1992) e municipais (Baddini, 2002; Prestes, 2001; Straforini, 2001; Zimmermann, 1992).

Para entender o processo de evolução urbana, elegemos uma base concreta para o estudo da problemática apresentada, ou seja, um espaço urbano de referência. 
Definimos, assim, esse espaço urbano sendo o da área urbanizada de Sorocaba, em diferentes períodos.

Localizada a sudoeste do Estado de São Paulo, Sorocaba é o nosso estudo de caso. Notamos que, desde a sua formação, a relação entre o sistema viário e a ocupação urbana é bastante marcante na configuração do seu espaço urbano.

Sorocaba, em função de sua localização geográfica estratégica (Santos, 1999), tem vocação como lugar de passagem e parada. A dinâmica socioeconômica regional característica de Sorocaba valida essa vocação. Sorocaba apresenta, ainda, diversas mudanças na estruturação urbana ao longo do seu crescimento urbano.

Dessa forma, temos como objetivo principal analisar a evolução do processo de estruturação do espaço urbano de Sorocaba ao longo do período compreendido entre a formação do povoado e a configuração da cidade no ano 2000. Para tanto, em cada período estudado, relacionamos a articulação entre os aspectos socioeconômicos aos elementos da estrutura urbana, ilustrados em croquis.

Tendo por referência alguns aspectos da teoria marxista da produção do espaço urbano (Campos Filho, 1992; Castells, 2006; Villaça, 2001), adotamos no estudo da evolução urbana de Sorocaba uma abordagem analítico-descritiva que reflete a metodologia utilizada.

Assim, ao longo do texto, à medida que apresentamos as características socioeconômicas, regionais e urbanas de Sorocaba nos diferentes períodos, descrevemos e analisamos o processo de evolução urbana com o auxílio dos croquis, elaborados por nós.

Em cada croqui apresentamos o crescimento urbano, em forma de mancha, tendo como referência a mancha do ano anterior. Ainda, dimensionamos esse crescimento planimetrando a sua área e comparando à área do ano anterior. Utilizamos para isso ferramentas de desenho do programa AutoCAD 2011, usado para a elaboração dos mapas - elaborados com base em dados da Prefeitura Municipal de Sorocaba e bibliografia específica.

Assim, em função da metodologia utilizada, nosso trabalho divide-se em três capítulos: 
Inicia-se com o Capítulo 1 - Sorocaba: cidade e região - em que apresentamos a localização de Sorocaba e sua situação atual. Além disso, inserimos a evolução urbana de Sorocaba no contexto regional, nacional e estadual.

No Capítulo 2 - Os Caminhos como indutores do crescimento urbano de Sorocaba abordamos a evolução urbana de Sorocaba desde antes de 1600, período que antecedeu a sua formação até 1875 .

No Subcapítulo 2.1 - Precedentes do povoamento de Sorocaba - discutimos a respeito das condicionantes socioespaciais, ou seja, sobre os precedentes do povoamento de Sorocaba antes de 1600.

No Subcapítulo 2.2 - Evolução Urbana de 1600 a 1700 - iniciamos com a análise da constituição da Vila de Nossa Senhora da Ponte. Desde as diversas tentativas de formação não bem sucedidas até a efetiva fundação dela em 1661. Aliado a isso, estudamos como o Bandeirismo influenciou a formação e a constituição da Vila.

Já no Subcapítulo 2.3 - Evolução Urbana de 1700 a 1875 - estudamos o período da mercantilização e da constituição da cidade de Sorocaba. Discutimos como os caminhos dos tropeiros e o Tropeirismo contribuíram para o crescimento urbano de Sorocaba.

No Capítulo 3 - A Ferrovia como indutora do crescimento urbano de Sorocaba analisamos a evolução urbana de Sorocaba de 1875 a 1954.

No Subcapítulo 3.1 - Evolução Urbana de 1875 a 1930 - analisamos como se formaram as bases da industrialização de Sorocaba, ou seja, quais as condicionantes socioeconômicas e espaciais que levaram Sorocaba a desenvolver mais tarde seu parque industrial. Principalmente, estudamos a influência desse processo no desenvolvimento da estrutura urbana de Sorocaba.

No Subcapítulo 3.2 - Evolução Urbana de 1930 a 1954 - falamos sobre o desenvolvimento socioeconômico de Sorocaba e, sobretudo, sobre o estabelecimento de indústrias como as de cimento e metalurgia. A diversificação industrial e o aumento das atividades urbanas propiciaram um significativo crescimento do espaço urbano.

No Capítulo 4 - As Rodovias como indutoras do crescimento urbano de Sorocaba analisamos a evolução urbana de Sorocaba de 1954 a 2000. Discorremos sobre o incentivo 
estadual e municipal ao transporte rodoviário, o qual substituiu aos poucos o transporte sobre trilhos que, no final do século XX, já apresentava sinais de decadência.

Em função disso, a estrutura urbana passou a ter a expansão urbana direcionada para as rodovias, o que culminou em outro modo de ocupação urbana. Falamos também sobre o incentivo municipal para a implantação de indústrias e sobre os planos diretores de Sorocaba.

Posteriormente, finalizamos com as Considerações Finais, nas quais apresentamos as conclusões das análises realizadas no decorrer dos capítulos anteriores.

Vemos que os caminhos dos índios, bandeirantes e tropeiros foram responsáveis por induzir o crescimento urbano de Sorocaba. Depois, o crescimento foi induzido pela construção da ferrovia e, por fim, induzido pela construção das rodovias e dos acessos urbanos de ligação a essas rodovias. Ainda, apresentamos croquis-síntese da evolução urbana de Sorocaba, divididos em períodos, que condizem com a divisão dos capítulos apresentados nesse trabalho. 


\section{Capítulo 1. Sorocaba: cidade e região}

\subsection{Localização e situação atual}

Sorocaba está localizada a sudoeste do Estado de São Paulo a cerca de noventa e sete quilômetros da cidade de São Paulo, a capital paulista.

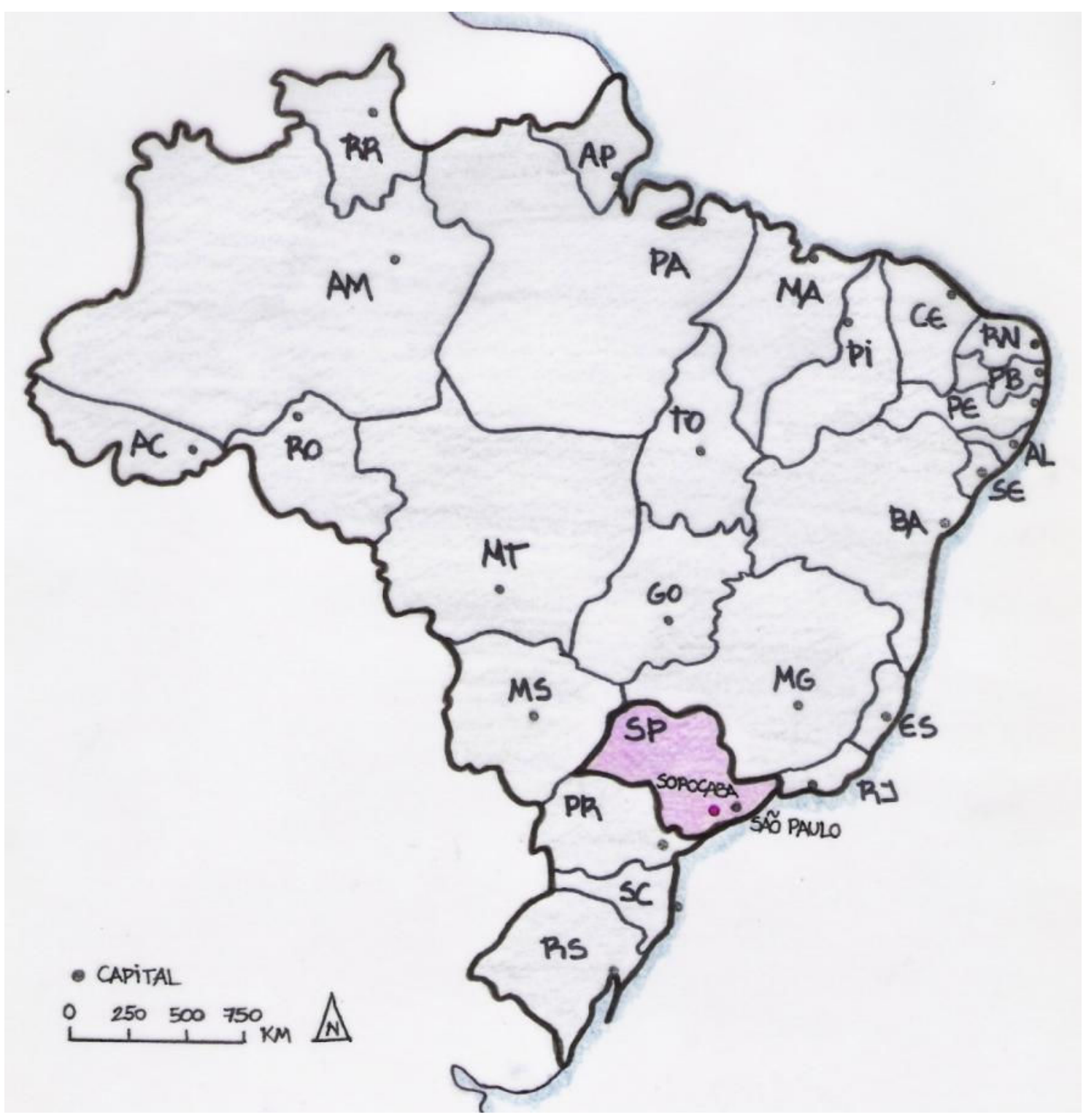

Croqui 1. Croqui de localização regional de Sorocaba.

Baseado em: Simielli, 1997. Crédito: Andressa Celli. 
Segundo Santos (1999), Sorocaba situa-se na região geomorfológica da depressão periférica do Estado de São Paulo, possuindo, assim, uma variação de altitude entre 500 e $750 \mathrm{~m}$.

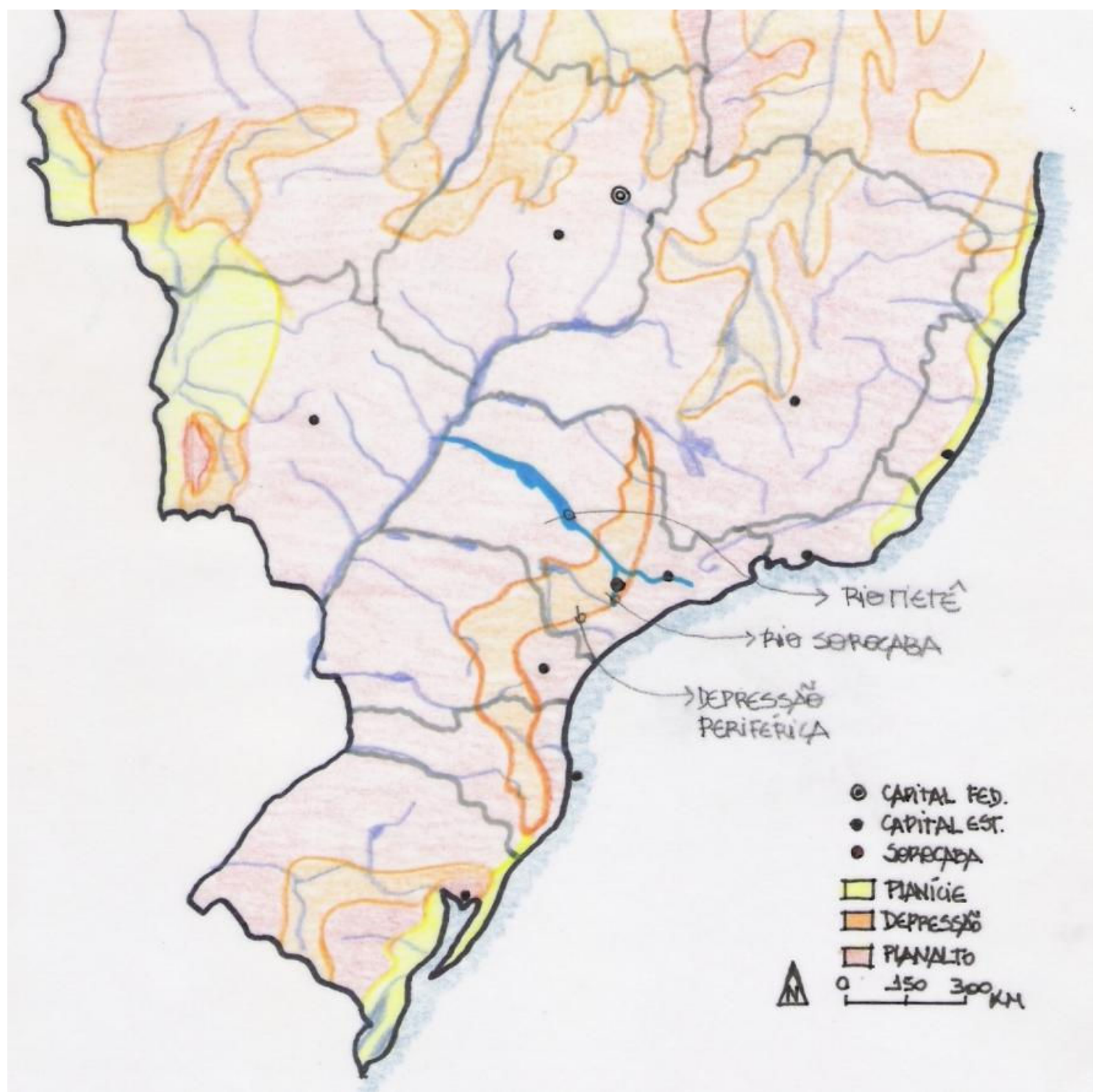

Croqui 2. Croqui de caracterização topográfica e hídrica regional.

Baseado em: Ross, 1985. Crédito: Andressa Celli. 
A cidade é cortada pelo rio Sorocaba, que nasce da junção dos rios Sorocamirim, Sorocabaçu e Una; desaguando no rio Tietê ao norte, na cidade de Laranjal Paulista.

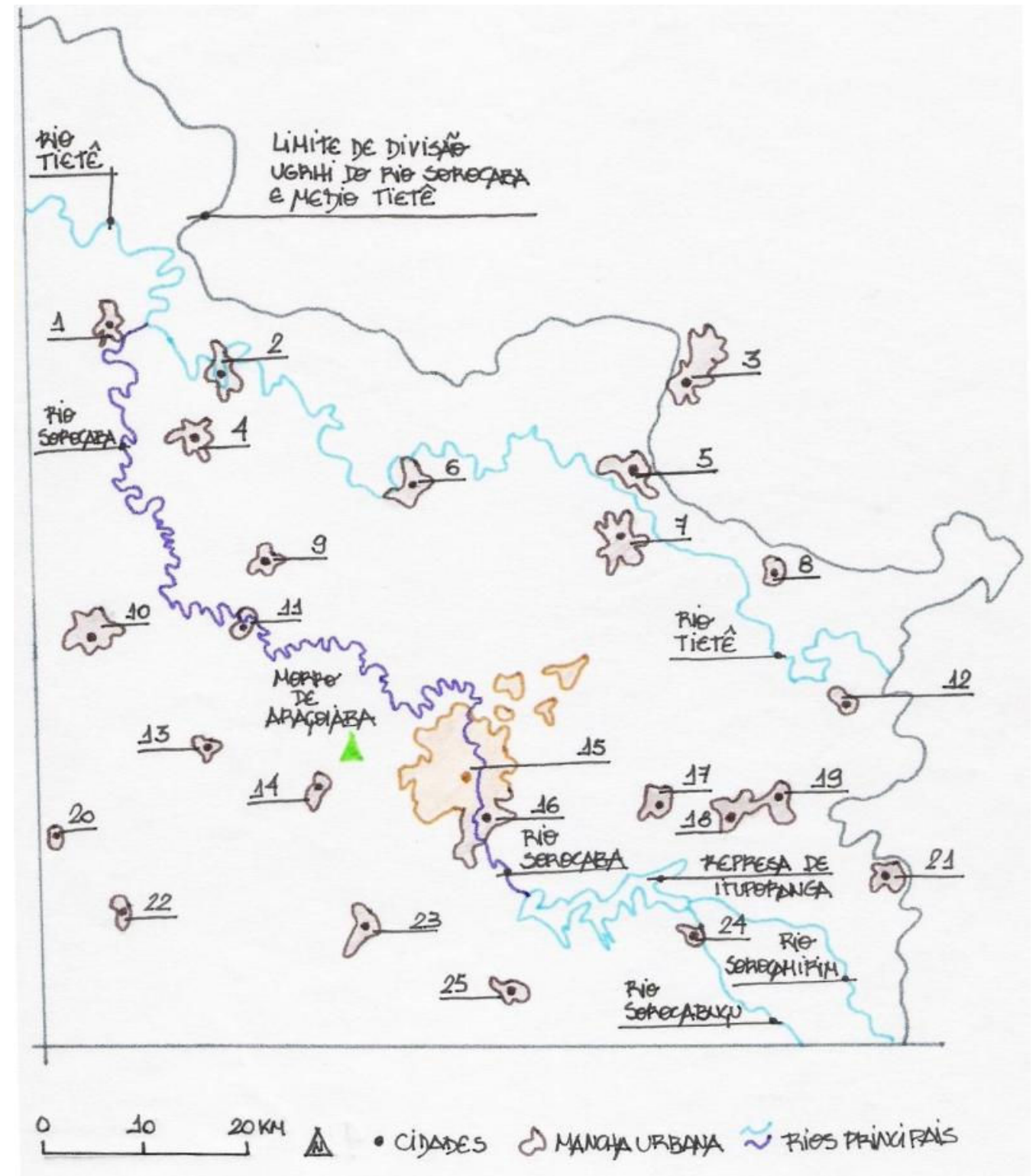
1. Laranjal Paulista
2. Tietê
3. Indaiatuba
4. Cerquilho
5. Salto
6. Porto Feliz
7. Itu
8. Cabreúva
9. Boituva

10. Tatuí

11. Iperó

12. Araçariguama

13. Capela do Alto

14. Araçoiaba da Serra

15. Sorocaba

16. Votorantim

17. Alumínio

18. Mairinque

19. São Roque

20. Alambari

21. Vargem Grande Paulista

22. Sarapurí

23. Salto de Pirapora

24. Ibiúna

25. Piedade

Croqui 3. Croqui dos principais rios e núcleos urbanos da região de Sorocaba.

Baseado em: Mapa de Demandas da URGHI CBH-SMT, 2011. Crédito: Andressa Celli. 


\section{Juntamente com}

(...) Campinas, São José dos Campos e Santos, o município de Sorocaba é uns principais polos urbanos do entorno imediato da região metropolitana da Grande São Paulo. Nas últimas duas décadas estes polos tiveram seu parque produtivo significativamente ampliado pelo movimento de expulsão/extravasamento de atividades produtivas - especialmente as industriais - da metrópole paulistana. Dotados de excelente acessibilidade rodoviária aos principais mercados brasileiros - com destaque para a própria região metropolitana de São Paulo, os polos urbanos e as regiões agrícolas do interior - tornou-se uma boa alternativa para a implantação de muitas empresas que passaram a não ter na Grande São Paulo condições operacionais adequadas. (Relatório de Caracterização, 1999, p.5)

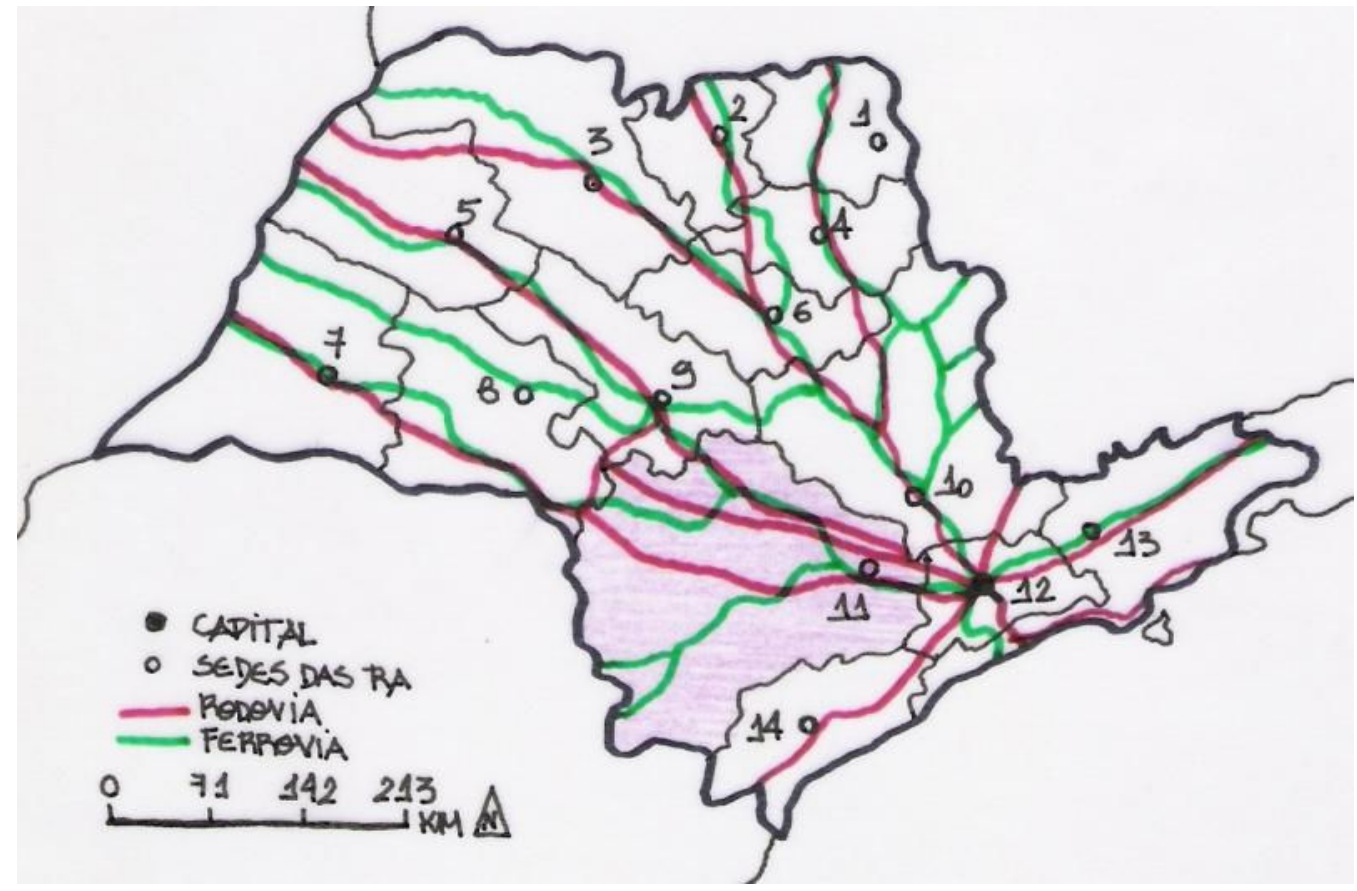
1. Franca
2. Barretos
3. São José do Rio Preto
4. Ribeirão Preto
5. Central

6. Presidente Prudente

7. Araçatuba

8. Marília

9. Bauru

10. Campinas
11. Sorocaba

12. São Paulo

13. São José dos Campos

14. Registro

Croqui 4. Croqui das Regiões Administrativas do Estado de São Paulo.

Baseado em: Simielli, 1997; Buganza, 2005. Crédito: Andressa Celli. 
De acordo com a Prefeitura Municipal de Sorocaba e, "segundo o Instituto Brasileiro de Geografia e Estatística (IBGE)" Sorocaba “tem 586.625 habitantes, conforme o Censo 2010." A cidade de Sorocaba é sede de uma das Regiões Administrativas mais prósperas do Estado de São Paulo. "Polo de uma região com mais de 2 milhões de habitantes, Sorocaba conta com uma grande diversidade econômica." (Prefeitura Municipal de Sorocaba)

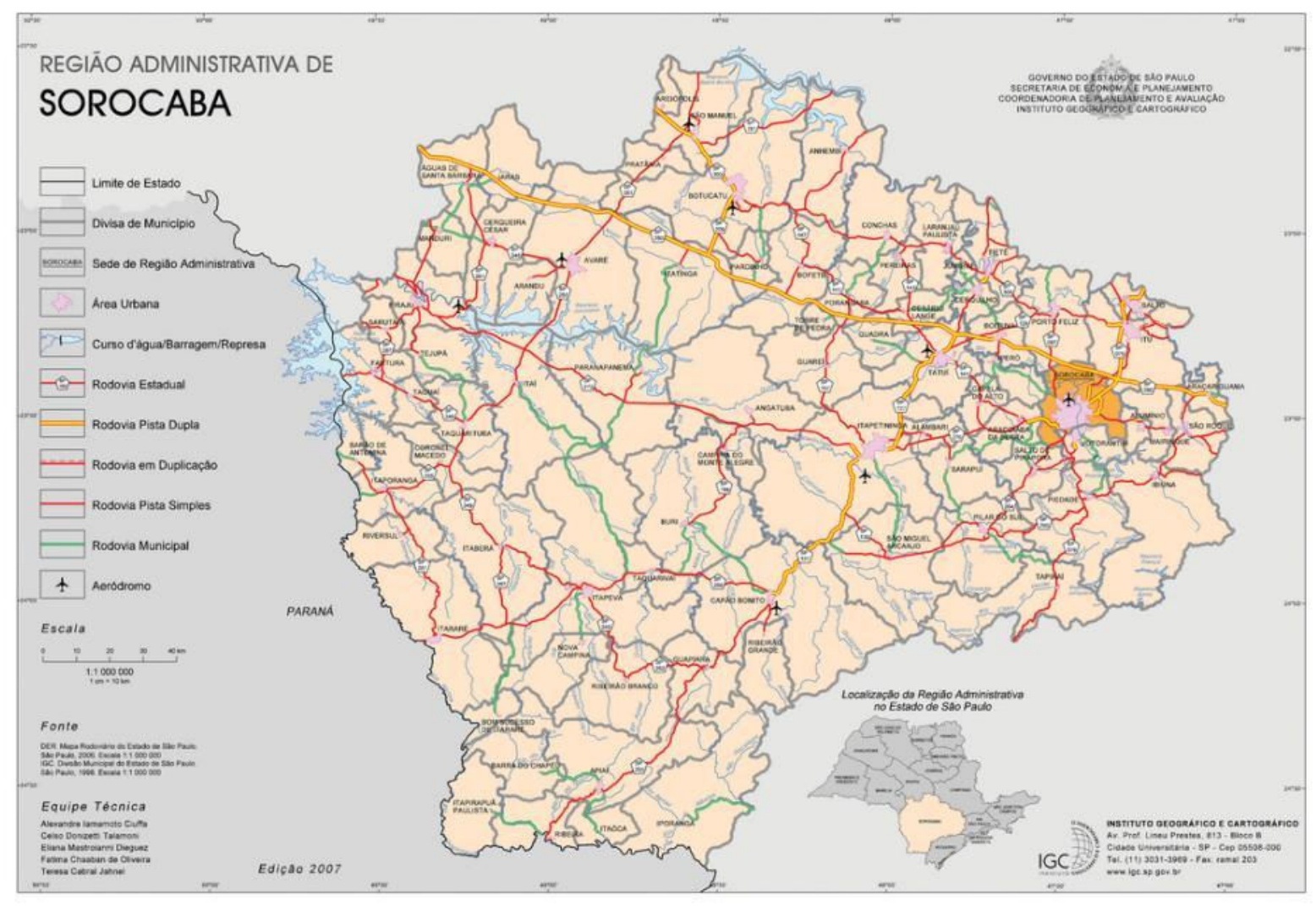

Figura 1. Mapa da Região Administrativa de Sorocaba.

IGC, 2007. 
De acordo com Buganza (2005, p. 58), "a Região Administrativa de Sorocaba é a maior do Estado de São Paulo em extensão territorial” e “está próxima das duas regiões economicamente mais importantes do Estado", São Paulo e Campinas. A Região Administrativa de Sorocaba, segundo dados do Governo do Estado de São Paulo (1981),

(...) está dividida em 5 Regiões de Governo (RG), totalizando 79 municípios. São elas: RG de Avaré; RG de Botucatu; RG de Itapeva; RG de Itapetininga; e a RG de Sorocaba. A RG de Sorocaba (RGS) é formada por 18 municípios: Alumínio, Araçariguama, Araçoiaba da Serra, Ibiúna, Iperó, Itu, Jumirim, Mairinque, Piedade, Pilar do Sul, Porto Feliz, Salto de Pirapora, Salto, São Roque, Sorocaba, Tapiraí, Tietê e Votorantim. (Buganza, 2005, p. 58)

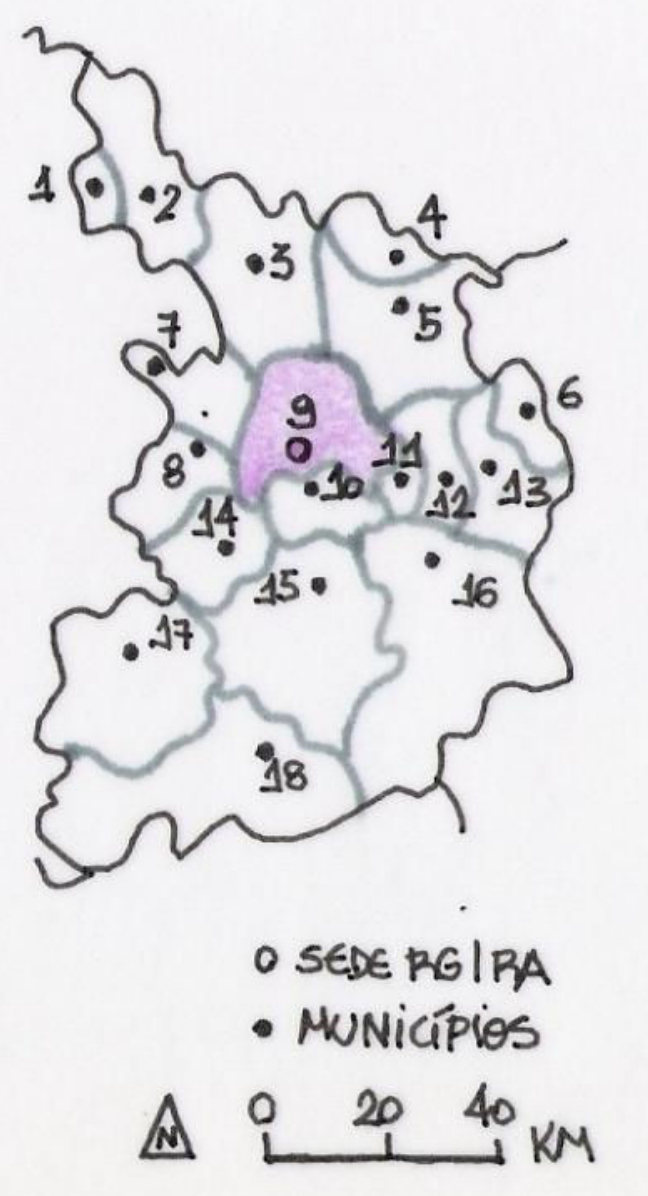
1. Jurumim
2. Tietê
3. Porto Feliz
4. Salto
5. Itu
6. Araçariguama
7. Iperó
8. Araçoiaba da Serra
9. Sorocaba
10. Votorantim
11. Alumínio
12. Mairinque
13. São Roque
14. Salto de Pirapora
15. Piedade
16. Ibiúna
17. Pilar do Sul
18. Tapiraí

Croqui 5. Croqui da Região de Governo de Sorocaba. Baseado em: Simielli, 1997; Buganza, 2005. Crédito: Andressa Celli. 
Sorocaba está ligada ao restante do Estado de São Paulo por uma ferrovia que é administrada, atualmente, pela ALL (América Latina Logística), segundo dados da Prefeitura Municipal de Sorocaba. Além disso, Sorocaba localiza-se em um importante

(...) entroncamento de rotas para o interior desde os tempos coloniais, Sorocaba hoje se articula por uma rede rodoviária em que se destacam: as Rodovias Castelo Branco e Raposo Tavares para a Capital e oeste paulista; a SP-75 para Campinas, norte paulista e triângulo mineiro; SP-79 para o Vale do Ribeira e litoral sul paulista; SP-270/SP-258 para o nordeste paranaense. (Relatório de Caracterização, 1999, p.5)

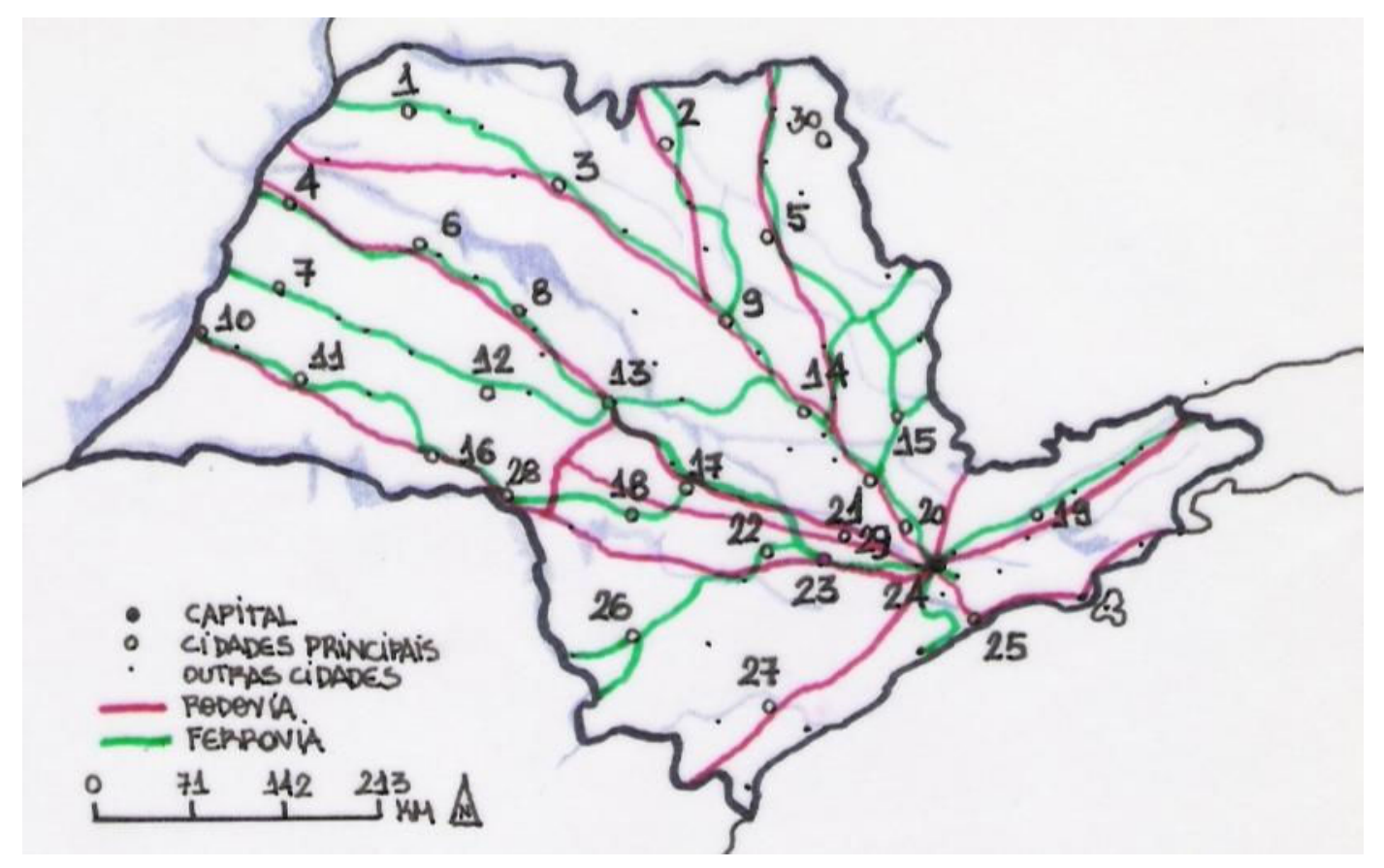
1. Jales
2. Barretos
3. São José do Rio Preto
4. Andradina
5. Ribeirão Preto
6. Araçatuba
7. Dracena
8. Lins
9. Araraquara
10. Presidente Epitácio

11. Presidente Prudente

12. Marília

13. Bauru

14. Rio Claro

15. Mogi Mirim

16. Assis

17. Botucatu

18. Avaré

19. São José dos Campos

20. Jundiaí

21. Campinas
22. Tatuí
23. Sorocaba
24. São Paulo
25. Santos
26. Itapeva
27. Registro
28. Ourinhos
29. Itu
30. Franca

Croqui 6. Croqui do Sistema Viário do Estado de São Paulo.

Baseado em: Simielli, 1997. Crédito: Andressa Celli. 
Finalmente, o município de Sorocaba faz divisa com as cidades de Porto Feliz e Itu ao norte, Votorantim ao sul, Alumínio e Mairinque a leste e com Araçoiaba da Serra e Iperó a oeste. Vemos que a cidade apresenta ligações urbanas de acesso a essas cidades vizinhas, que configuraram a estrutura urbana de Sorocaba.

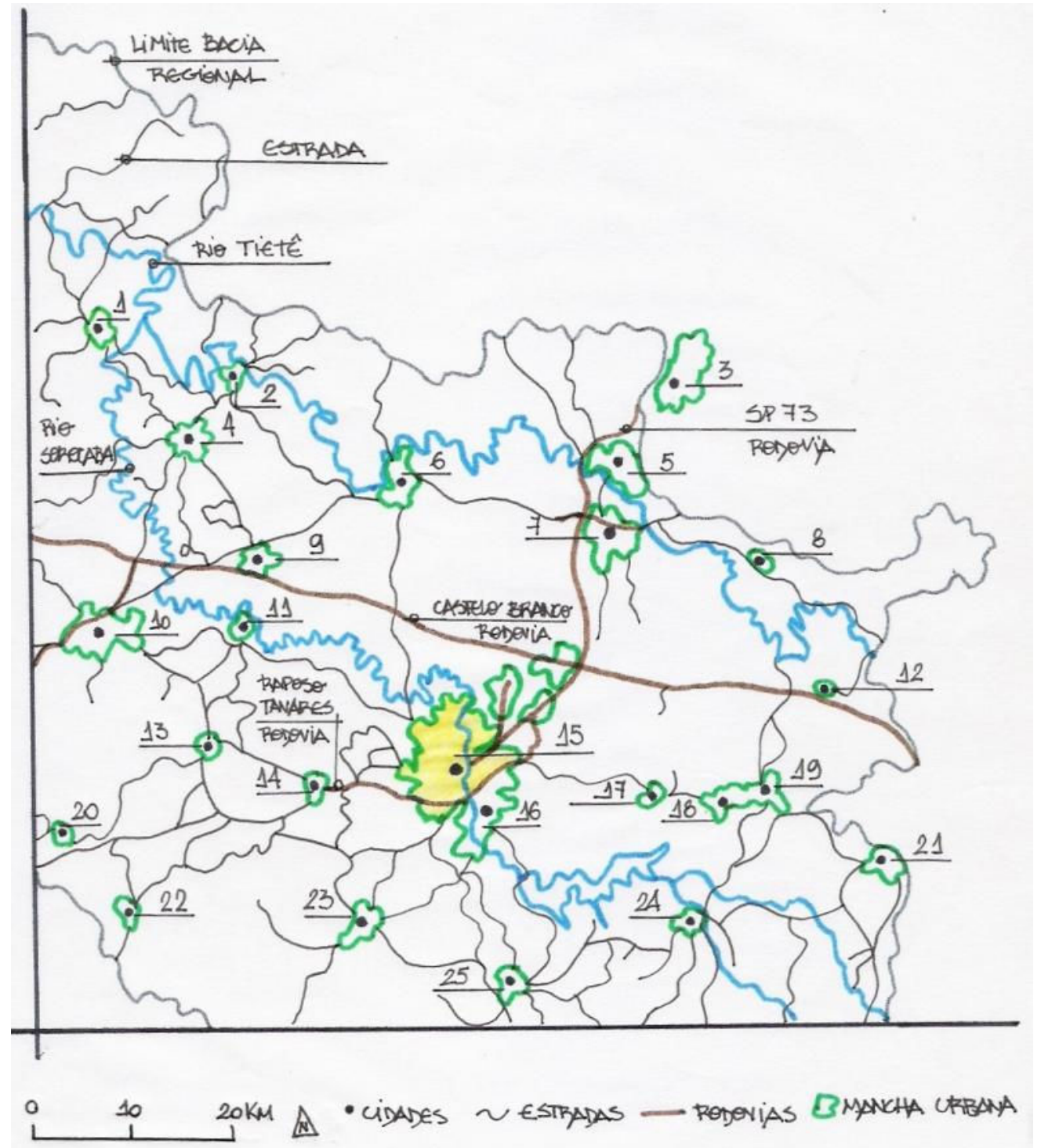
1. Laranjal Paulista
2. Tietê
3. Indaiatuba
4. Cerquilho
5. Salto
6. Porto Feliz
8. Cabreúva
9. Boituva

10. Tatuí

11. Iperó

12. Araçariguama

13. Capela do Alto

14. Araçoiaba da Serra

15. Sorocaba

16. Votorantim

17. Alumínio

18. Mairinque

19. São Roque

20. Alambari

21. Vargem Grande Paulista

22. Sarapurí

23. Salto de Pirapora

24. Ibiúna

25. Piedade

Croqui 7. Croqui Político e do Sistema Viário Regional de Sorocaba.

Baseado em: Mapa de Demandas da URGHI CBH-SMT, 2011. Crédito: Andressa Celli. 


\subsection{Contexto Regional}

De acordo com Santos (1999), as características do relevo e da rede hídrica no eixo Brasil-Peru estabeleceram a formação de um importante eixo de ligação entre os territórios nacional e internacional. Esse eixo de ligação era uma rota indígena destinada à troca de produtos e ligação entre grupos indígenas estabelecidos ao longo e nas proximidades desse eixo. Conhecida como Peabiru, essa rota constituía um "caminho transul-amerciano, que ligava os oceanos Atlântico e Pacífico" (Jornal Cruzeiro do Sul, 2004, p. 4).

De acordo com Bond (2011) a rota do Peabiru era composta por um ramal principal e outros secundários, seguidos de ramificações, que ligavam as diversas ocupações indígenas. Nomeadas também como caminhos do Sol, esses ramais

partiam de pontos próximos às atuais cidades de São Vicente, Iguape, Cananéia e Paranaguá, entre outras, unificando-se no interior do Estado do Paraná. Atravessavam o Paraguai, atingiam a região habitada pelos Incas, nos Andes e daí seguiam até o Pacífico. (Jornal Cruzeiro do Sul, 2004, p. 19)

Podemos dizer, então, que a rede de caminhos do Peabiru era formada por vários ramais. Conforme demonstrado no croqui da página a seguir,

o tronco principal corresponderia à trilha que passava por São Vicente, Piratininga [São Paulo], Sorocaba, Itapetininga, Itapeva e Itararé, com um importante ramal que ia de '[Sorocaba] a Botucatu, de onde descia ao Paranapanema'. (...) A partir de Itararé, ela seguia (...) pelos rios Tibagi, Ivaí e Piqueri, até o salto no rio Paraná e atravessava o Paraguai e Bolívia até atingir o Peru. (Caminho descrito pelos pesquisadores Aurélio M. G. Abreu e Luiz Galdino, apud Jornal Cruzeiro do Sul, 2004, p. 19). 


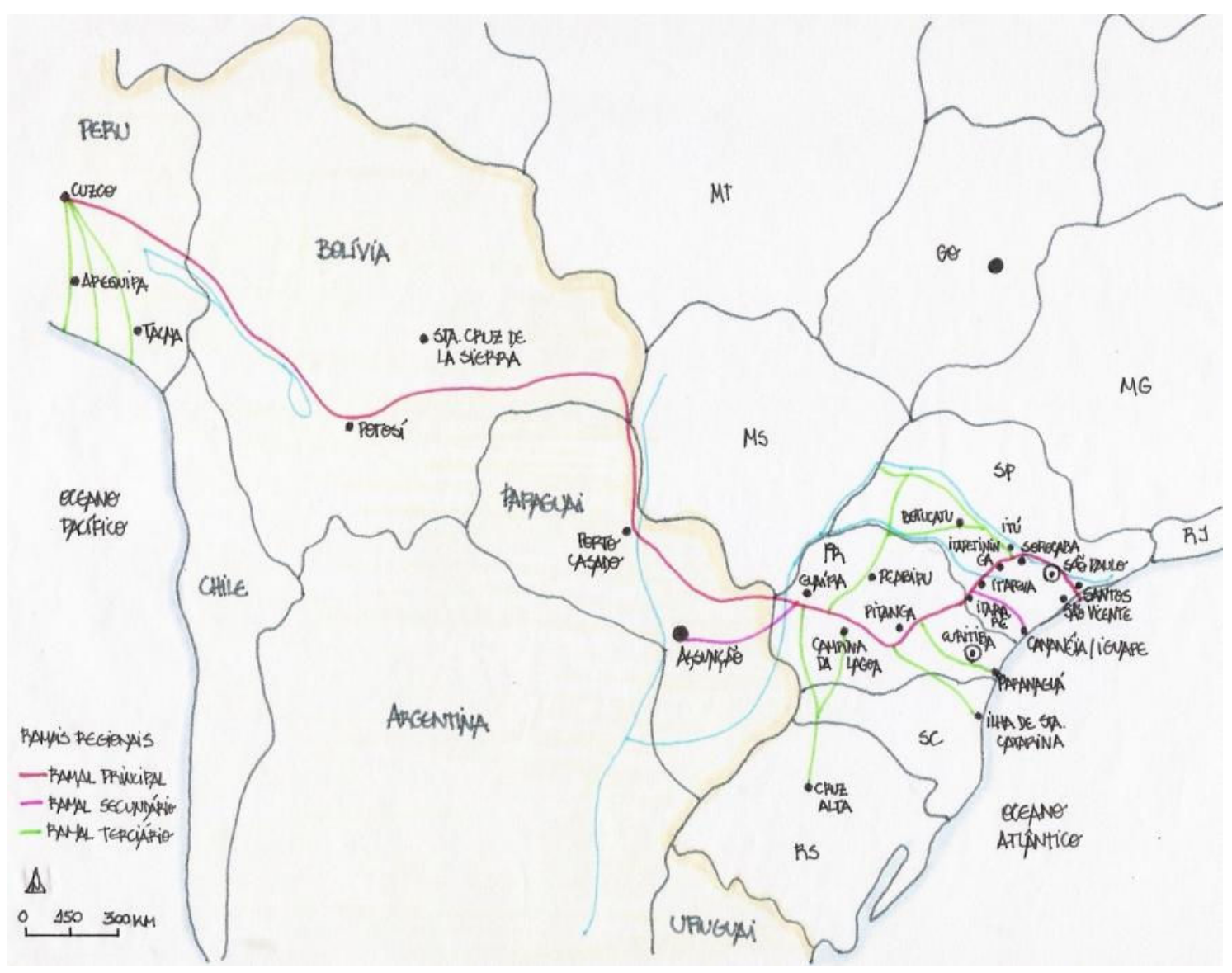

Croqui 8. Croqui do Peabiru na América do Sul.

Baseado em: Bond, 2011. Crédito: Andressa Celli. 
A partir da leitura do croqui anterior, constatamos que havia uma intrínseca relação entre os eixos de ligação formados pelas milenares rotas indígenas e os espaços de assentamento constituídos pela ocupação humana formada ao longo dos ramais do Peabiru. Esse fato confirma o caráter de ligação que as rotas exerciam ao longo do seu percurso.

Tais características induziram a formação de povoados no interior do Estado de São Paulo, como Sorocaba. Segundo Reis Filho (1968), esses povoados foram fundados por bandeirantes (1600 a 1700), desbravadores do sertão paulista.

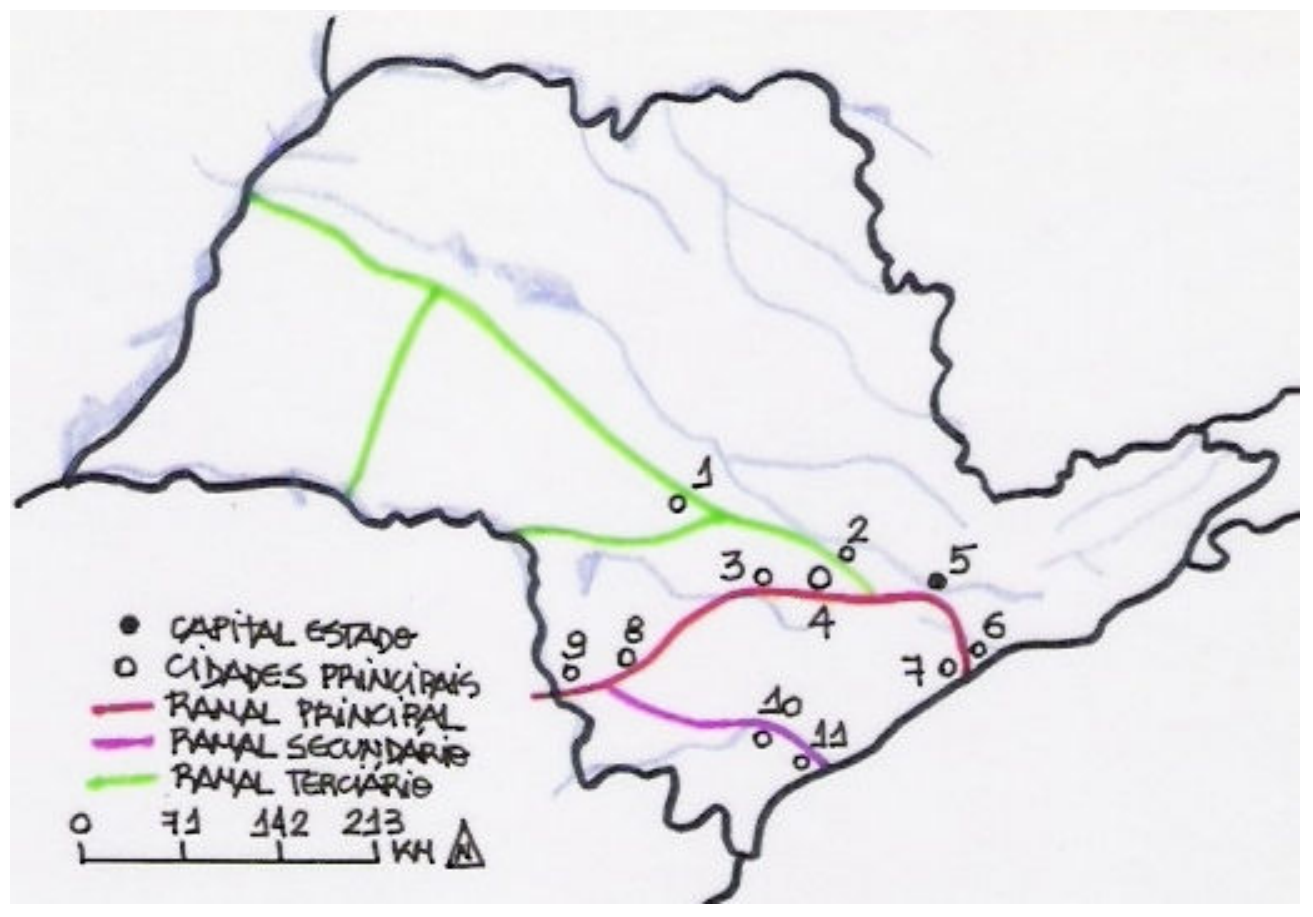
1. Botucatu
5. São Paulo
6. Santos
9. Itararé
2. Itu
7. São Vicente
10. Registro
3. Itapetininga
8. Itapeva
11. Cananéia
4. Sorocaba

Croqui 9. Croqui do Peabiru no Estado de São Paulo.

Baseado em: Simielli, 1997; Bond, 2011. Crédito: Andressa Celli. 
A distribuição de terras em sesmarias ${ }^{1}$, feita pela Coroa, contribuiu para a formação desses povoados, especialmente a das vilas do planalto paulista. Os donatários, os homens responsáveis pelas sesmarias, foram os primeiros desbravadores das terras do interior paulista, os primeiros bandeirantes.

Eles eram incumbidos de criar vilas nas terras de suas posses: "[a] Coroa procurava deixar aos donatários as principais tarefas de urbanização, outorgandoIhes o poder de criação de vila" (Reis Filho, 1968, p. 60).

Segundo Reis Filho (1968), as vilas eram dirigidas por seus fundadores, os quais estabeleciam suas sedes administrativas e religiosas, ou seja, a Câmara e a Igreja. Nessas vilas, em razão do isolamento dos povoados, a Câmara tinha um papel muito atuante e independente em relação à Coroa.

Sorocaba, que estava na região de posse dos Fernandes e de suas sesmarias, foi fundada na mesma época que outras vilas, como Itu e Santana de Parnaíba. O interesse nas rotas dos bandeirantes de exploração de metais preciosos e de povoamento influenciou diretamente o desenvolvimento destas, além de permitir a fundação de outras vilas.

Verificamos, assim, com base em Prestes (2001), que Sorocaba foi uma importante paragem das bandeiras, especialmente na época da busca por metais preciosos. Além disso, foi também o berço de muitos exploradores: muitos sorocabanos descobriram ouro e outros minérios no Oeste.

Em decorrência das expedições, esses exploradores tiveram efetiva participação na fundação de várias cidades no Oeste do Brasil. Um exemplo disso foi a criação da cidade de Cuiabá (Jornal Cruzeiro do Sul, 2004).

\footnotetext{
1 "Durante todo o período colonial, o fundamento da propriedade da terra no Brasil era o sistema de sesmarias, com a terra outorgada pelo Governo Imperial. Toda terra não doada em sesmarias era teoricamente, de domínio público ou terra devoluta. Nesse sistema, o sesmeiro [ou donatário] tinha somente a posse da terra e não o domínio [propriedade] sobre ela" (Pessoa, 2003, p. 53).

"Com as mudanças, tanto de ordem política como de ordem econômica que ocorreram e com a necessidade de uma solução para a situação dos migrantes que, não dispondo de títulos de posse, se estabeleciam em terras que conquistavam, vivendo à margem da administração colonial, em 18220 sistema de sesmarias foi extinto. Com isso, o Brasil ficou vinte e oito anos sem qualquer lei específica que regulamentasse a aquisição de terras, quando somente era dado o direito de posse da terra; ou seja, as terras eram doadas a quem tivesse disposição e disponibilidade de cultivá-la" (Pessoa, 2003, p. 54).
} 


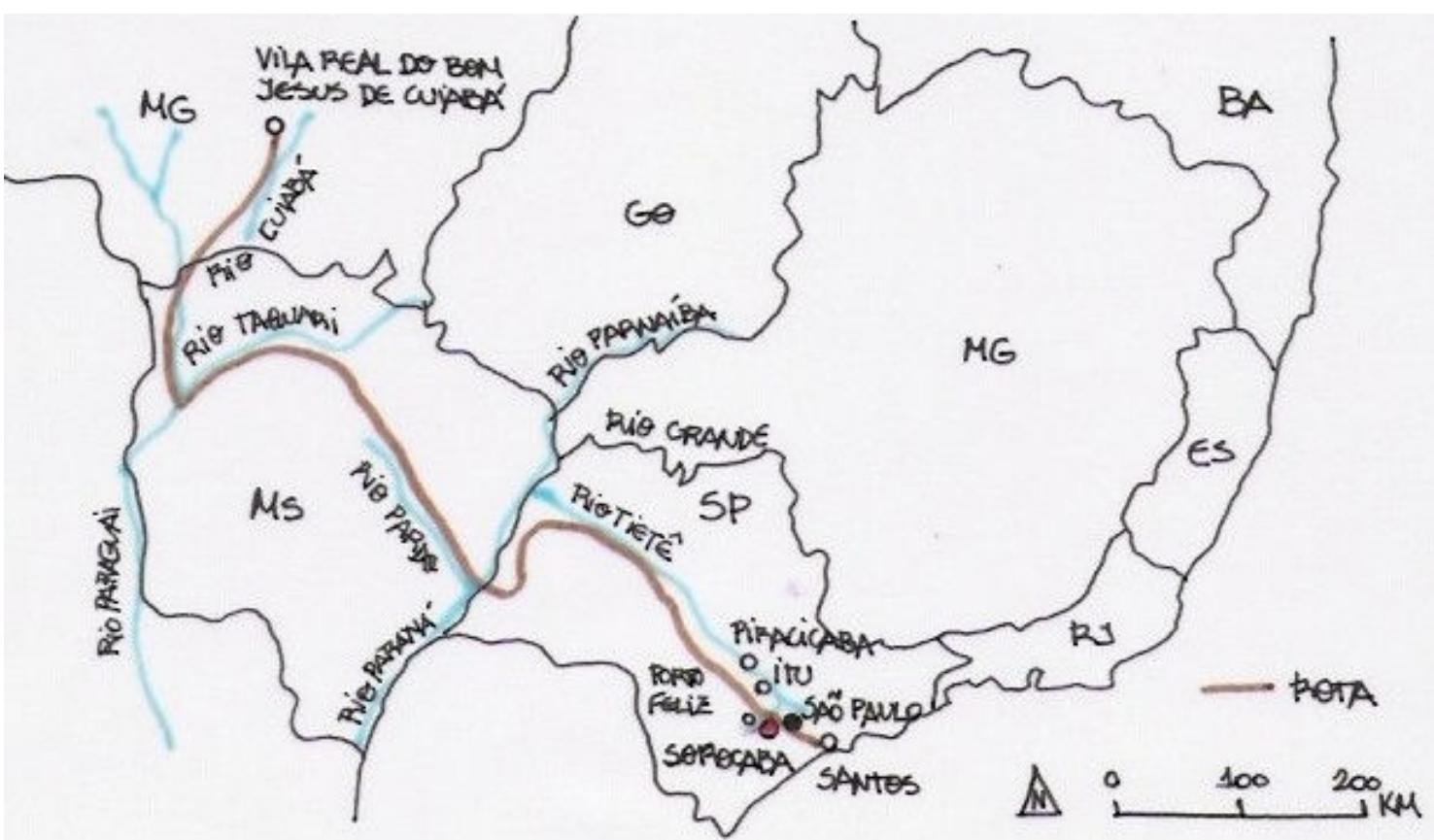

Croqui 10. Croqui da Rota para o Oeste e Vilas fundadas por bandeirantes em seu entorno.

Baseado em: Jornal Cruzeiro do Sul, 2004. Crédito: Andressa Celli.

A partir do século XVIII, o ciclo do ouro², a produção de cana-de-açúcar e a criação da rede de cidades novas no Oeste e Sul do país foram importantes processos que determinaram uma nova etapa no desenvolvimento socioeconômico nacional.

Esses processos, por sua vez, foram articulados e incentivados pela Coroa portuguesa. Podemos dizer que, a partir disso, foi dado início ao período do Tropeirismo $^{3}$ (1700 a 1875).

Do ponto de vista econômico, o Tropeirismo marcou o desenvolvimento do mercantilismo no país e, aliado a isso, uma nova forma de se produzir o espaço. $\mathrm{O}$ comércio exigia, dessa forma, a ampliação do mercado consumidor e, com isso, maior facilidade de comunicação com a nova rede de cidades.

\footnotetext{
2 "Vimos que a busca por metais preciosos no bandeirismo resultou na descoberta de ouro e diamantes. É preciso salientar que o tropeirismo somente foi iniciado depois disso, com o desenvolvimento da mineração e o comércio associado a ela" (Prestes, 2001).

3 "O ouro foi o consumidor forçado do muar sulino. Depois, com o fim do ouro, o açúcar planaltino, a Baixada Fluminense e depois de tudo isso o café, foram os grandes alimentadores do ciclo econômico do muar, o qual teve grande vigência ate o terceiro quartel do século XIX" (Ellis Júnior, 1950, p. 76; apud Santos, 1999, p. 77).
} 
As rotas de muares, então, fariam esse papel de ligação entre as cidades. Elas seriam responsáveis pela interligação da rede urbana que se formava, tornando-se assim essenciais para o desenvolvimento do Tropeirismo.

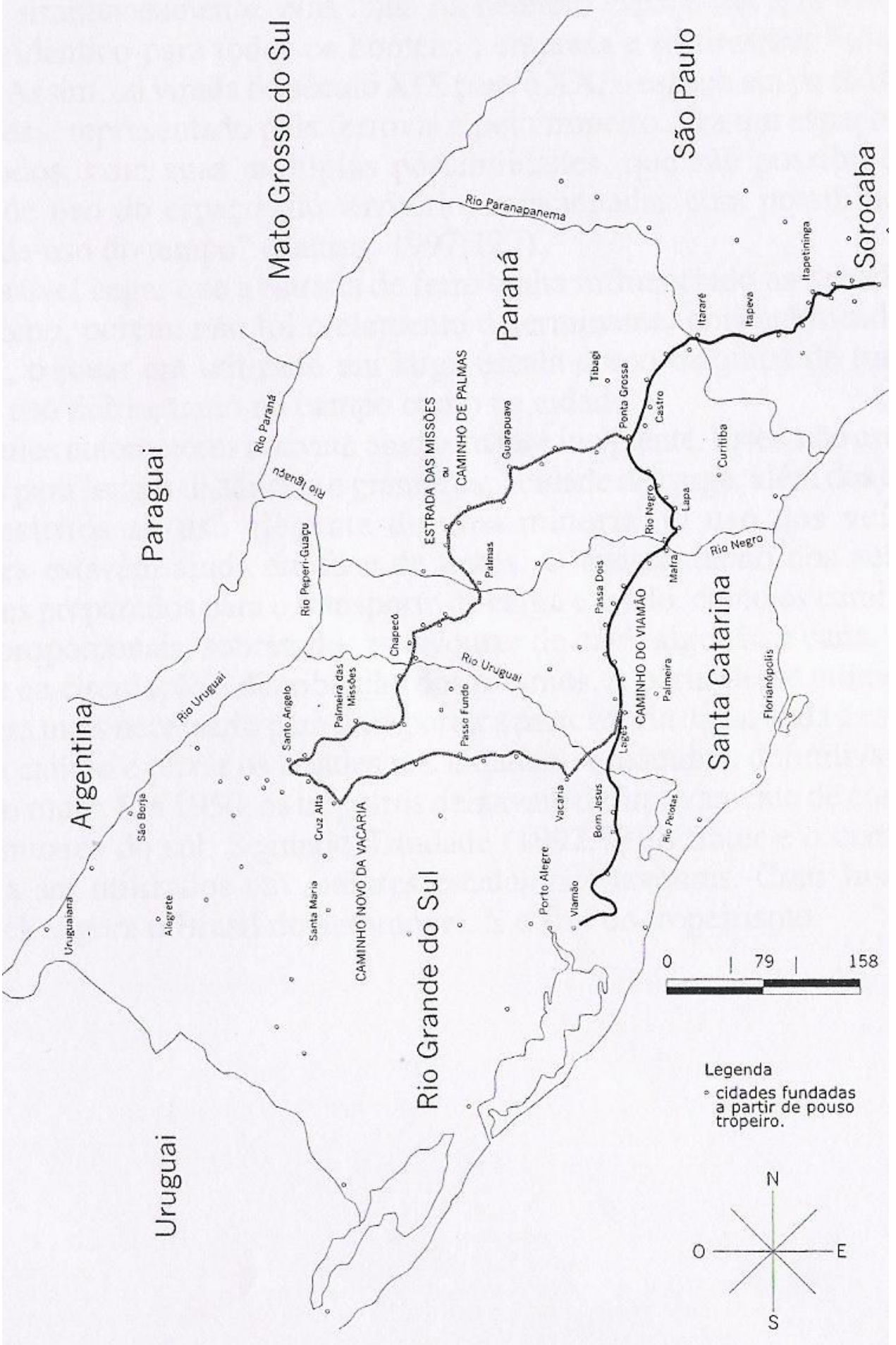

Figura 2. Rotas Tropeiras de muares do Sul para Sorocaba.

Trindade, 1992; apud Straforini, 2001. 
Fazia-se necessário, então, estabelecer uma política de transporte de mercadorias que se ajustasse à dinâmica do processo mercantilista. Como podemos observar,

[o] Brasil necessitava de meio de transporte para carregar o ouro das minas ao porto de embarque e trazer os produtos indispensáveis ao sustento da população que vivia da exploração das minas. (Santos, 1999, p. 74)

Assim, em função do consequente desenvolvimento do mercantilismo e das riquezas geradas nesse período, podemos afirmar a importância dessa política de transporte no âmbito socioeconômico nacional.

Uma vez estabelecida essa política, notamos que o "comércio de muares tornou-se uma das principais fontes de receita da capitania e, depois, da Província de São Paulo" (Jornal Cruzeiro do Sul, 2004, p. 90). Além disso, estimulou o contato e comércio entre regiões distantes de todo o país.

O Tropeirismo, isto é, o comércio de muares, foi incentivado diretamente pelo Estado. Esse transporte terrestre teve grande importância nacional à medida que tinha, como função principal, subsidiar a economia mercantilista da Coroa, seu real interesse.

É preciso destacar também o papel do tropeiro, uma vez que se torna o novo agente transformador do espaço urbano, substituindo a ação do bandeirante explorador.

O tropeiro, influenciado pela característica desbravadora do bandeirante, era talhado para o serviço de comércio de muares. Aliava o conhecimento indígena do meio ambiente ao da técnica trazida pelos portugueses (Straforini, 2001, p. 26).

Dessa forma, não podemos considerar o tropeiro apenas um condutor de mercadoria. Mais do que isso, ele era o responsável pelo funcionamento de toda a estrutura do comércio de muares. Sua posição social e profissional fazia dele uma pessoa importante e, assim, dava condições para que ele interferisse no desenvolvimento socioeconômico da rede de cidades. Ele, na verdade, 
(...) pertencia à gente melhor da província; para a compra das tropas, para registros e direção de sua indústria, era conveniente possuir certa instrução e algum capital, exigência que limitava o recrutamento dos membros de sua categoria e a fixava na classe dos mais abastados. Seleção profissional e social, portanto. (Taunay, 1939, tomo II p. 370, 371; apud Santos, 1999, p. 76)

Precisamos lembrar, no entanto, que o tropeiro não desempenhava sozinho todo esse percurso e atividades. Havia, ao contrário, uma comitiva que o acompanhava, ele era o dono da tropa. Assim, o tropeiro era

(...) patrão, homem rico que ganhava porcentagens em dinheiro ou mercadorias como forma de pagamento pelo serviço prestado. Contratava os camaradas, o cozinheiro e os aprendizes. (Straforini, 2001, p. 26)

Com base nos relatos e nas descrições apresentadas, é possível dizer que o ciclo do muar

foi um sistema social de extrema importância para a exploração e ocupação do território brasileiro nos séculos XVIII e XIX. (...) Uma complexa divisão social e territorial do trabalho se formou, comandada pelos interesses de criar, vender e negociar e tanger esses animais, proporcionando assim, o surgimento de inúmeras vilas que, mais tarde, se tornariam cidades. (Straforini, 2001, p. 21)

Desse modo "o sistema de viação interna do país represent[ou] um grande papel na vida e na economia da colônia" (Prado Júnior, 1956, p. 115). De acordo com Prado Júnior,

[o] que realmente merece destaque neste terreno é o comércio de gado. Este sim tem certo vulto no intercambio interno da colônia. E seu papel na formação do Brasil é considerável, pois estendendo-se sobre uma área muito extensa, como vimos, contribuiu grandemente para ligar entre si as diferentes partes do território brasileiro e seus núcleos de povoamento, que de outra forma se teriam conservado em segmentos estanques e sem possibilidades talvez de se unirem num bloco coeso, num único país como se deu. (Prado Júnior, 1956, p. 119) 
Nesse sentido, Sorocaba teve papel significativo na articulação da comunicação e do comércio de gado de caráter regional. Sua localização geográfica estratégica, por exemplo, fortaleceu a articulação entre as cidades.

Dessa forma, sua contribuição foi fundamental para esse processo de ligação entre as várias regiões brasileiras, o que culminou na constituição do território nacional unificado.

Sorocaba teve efetiva participação nesse processo, pois estava

(...) situada no ponto de encontro de antigos caminhos indígenas adotado pelos portugueses e da economia do muar no século XVIII e $\mathrm{XIX}$, com a grande lavoura da cana-de-açúcar implantada em suas portas pelo amplo oeste paulista. (Prestes, 2001, p. 50)

Mais uma vez, notamos que os caminhos indígenas foram responsáveis pelos principais eixos de ligação entre as regiões Sul e Sudeste do Brasil. Tanto os bandeirantes quanto os tropeiros souberam utilizar-se desses eixos para o desenvolvimento de suas atividades.

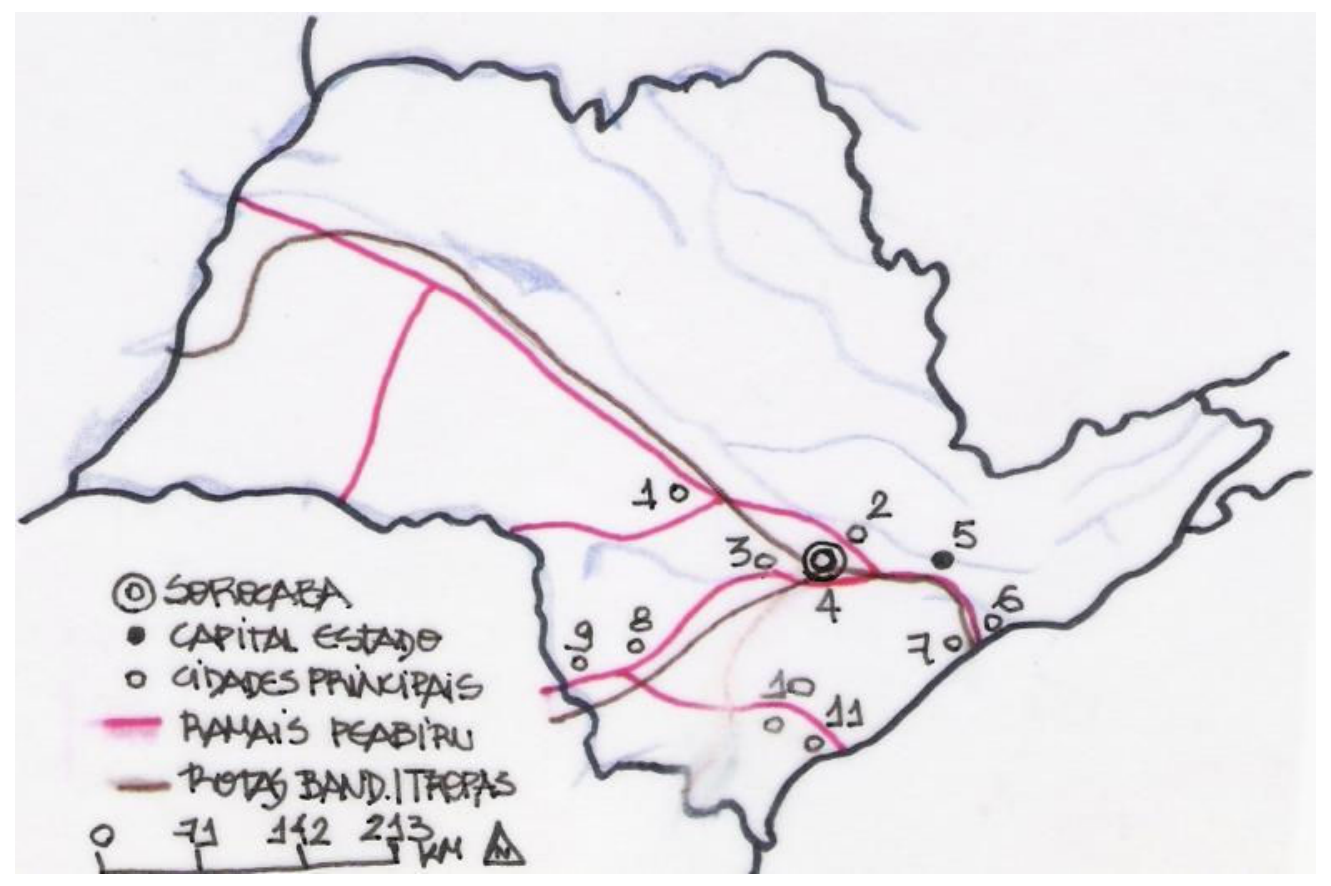

Croqui 11. Croqui de sobreposição das rotas do Peabiru e das rotas principais dos tropeiros.

Baseado em: Simielli,1997; Bond, 2005; Straforini, 2001. Crédito: Andressa Celli. 
Além de percorrerem os trajetos antigos, já formados pelos índios, criaram novos trajetos a partir desses eixos de ligação. Esses novos trajetos interligavam a nova rede de cidades que se formava no sul e sudeste do Brasil. E é nesse contexto que Sorocaba estava inserida. Mais uma vez, em função de sua localização estratégica. Afinal, a

via de transporte que interligava a zona de criação com o resto do país, tinha seu ponto terminal em Sorocaba, onde havia importante feira anual de bestas. (Singer, 2004, p. 153)

Ainda, de acordo com Caio Prado Jr.,

as transações [comerciais], nos meados do século passado, nas feiras de burros de Sorocaba, eram bastante vultuosas. (Prado Jr., 1953, p. 253; apud Singer, 2004, p. 153)

Sendo assim, podemos dizer que Sorocaba ganhou destaque tanto no comércio das mercadorias transportadas quanto no comércio dos próprios muares. Segundo Saint Hilaire,

[n]ão é, de resto, a agricultura que constitui a riqueza de Sorocaba e sim o comercio de muares não domesticados, comercio de que a cidade é, verdadeiramente, o entreposto. (Saint Hilaire 1940, trad. P. 251; apud Santos, 1999, p. 75)

Os Sorocabanos faziam a compra dos muares xucros produzidos no Sul e os vendiam treinados aos tropeiros do ouro, estabelecendo, assim, uma importante rede de caminhos entre essas regiões.

Esse comércio foi uma enorme fonte de renda para os Sorocabanos, que viam a cidade tomar importância econômica e territorial em função dessas condicionantes estabelecidas pelo mercantilismo. 


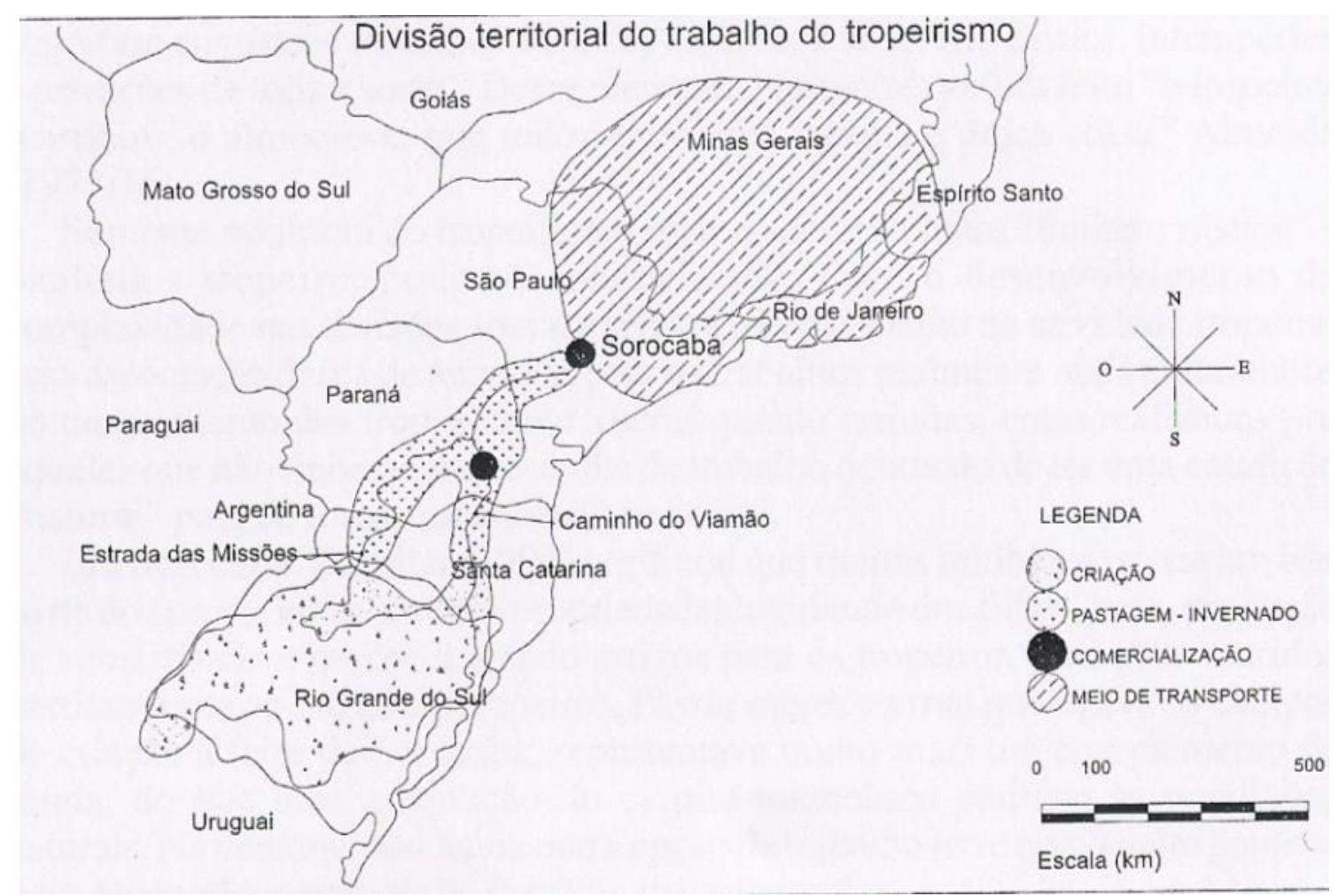

Figura 3. Área de Influência do Tropeirismo.

Straforini, 2001.

A criação de muares no Sul criou condições para a definição de diversas rotas de ligação. A rede de caminhos, estabelecida a partir do Peabiru, foi responsável pela consolidação do caminho entre São Paulo e Viamão, consolidada por Cristóvão Pereira, assim como o trecho entre Sorocaba e Curitiba. A estrada das missões ou caminho das Palmas também fazia parte dessa mesma rede. Assim,

Sorocaba era a "cidade eixo" entre o Sul, produtor de muares, e o Oeste, consumidor de muares (...) por isso tornou-se centro das feiras de animais. (Deffontaines, 1939, trans. 1947, p. 1591; apud Santos, 1999, p. 74)

A instituição das feiras ${ }^{4}$ de muares foi resultado de tais negociações que, com o tempo, foram se tornando abundantes e conhecidas em todo o Brasil e na região do Prata. De acordo com Klein (1989),

\footnotetext{
${ }^{4}$ As feiras de muares, em Sorocaba, duraram de 1733 a 1897 (Baddini, 2002, p. 92).
} 
(...) o tropeirismo era um sistema de produção, com nítida divisão territorial do trabalho. Cabia aos gaúchos a criação dos animais, aos paranaenses o aluguel de campos para as invernadas, além de terem também campos criatórios e, aos paulistas, a comercialização nas feiras realizadas em Sorocaba, pois era a partir delas que esses animais eram distribuídos para todas as regiões articuladas na economia mercantil colonial. Enquanto no Sul a divisão territorial do trabalho gerou um espaço predominantemente criatório, no Brasil central, o espaço era articulado em infinitas redes de rotas, possibilitando a comunicação e a inserção de lugares "perdidos" na economia brasileira e mundial. (Straforini, 2001, p. 24)

Segundo Prestes (2001), a partir de 1850, a transformação da vida urbana, antes incipiente e subordinada totalmente às atividades do campo e do comércio de gado, tornou-se aos poucos independente, uma vez que passou a se introduzir em algumas cidades paulistas atividades de produção tipicamente urbanas, como as de pequenas manufaturas e beneficiamento de matérias-primas.

Tais atividades foram primeiramente estimuladas pela presença de comerciantes, que proporcionaram o desenvolvimento de serviços que atendessem à dinâmica do comércio em cidades do interior paulista como Campinas e Sorocaba. Esta última, como vimos, teve papel significativo no comércio de muares e de atividades urbanas relacionadas ao Tropeirismo.

Essas cidades, em função do crescimento das atividades urbanas, desenvolveram de forma significativa sua ocupação urbana. Ao mesmo tempo, esse desenvolvimento foi estimulado pelo Estado, que promoveu o estabelecimento das pessoas nas cidades através da promulgação de uma legislação 5 em 1850, a 'Lei de Terras',

(...) que aprovava o acesso à propriedade somente pelo sistema de compra e venda. A todos que tivessem começado a cultivar o solo e pudessem justificar o seu direito de primeiro ocupante, permitia esta lei que registrassem os seus títulos de posse, num prazo de quatro anos. Essa lei veio revalidar as porções de terra relativas às sesmarias concedidas em 1822, ratificar ocupações e legitimar diretamente as aquisições por compra de terras. (Pessoa, 2003, p. 54)

5 “(...) o Brasil aprovou uma Lei de Terras que instituía um novo regime de propriedade em que a condição de proprietário não dependia apenas da condição de homem livre, mas também de pecúlio para a compra de terra, ainda que ao próprio Estado" (Martins, 2010, p. 09). 
O desenvolvimento dessas cidades foi estimulado também pelo cultivo de produtos agrícolas, que gerou riqueza e crescimento tal qual o ciclo do muar. Esse capital foi importante para a formação das bases da indústria paulista.

De acordo com Prestes (2001), o cultivo de café no Estado de São Paulo proporcionou um elevado nível de acumulação de capital que, por sua vez, foi responsável pela criação das bases da industrialização do Estado de São Paulo entre 1850 a 1930. As culturas do algodão e da cana-de-açúcar, guardadas as devidas proporções, também contribuíram para a formação das bases do processo industrial. As cidades as quais estavam ligadas a essas atividades de cultivo foram as mesmas que desenvolveram, no futuro, um parque industrial de dimensões consideráveis.

Em função da grande produção de café, algodão e cana-de-açúcar foi necessário o desenvolvimento de um sistema de transporte capaz de escoar a produção dessas matérias-primas agrícolas de forma mais eficiente que o sistema de tropas.

Os "homens e negócio, que agora são os fazendeiros e loteadores de terras, compreenderam rapidamente que a estrada era o prolongamento do trilho" (Monbeig, 1984, p. 199). E, assim, foram construídas algumas linhas férreas que atenderiam o interior e litoral do Estado de São Paulo. Houve então,

(...) a inauguração da Estrada de Ferro Santos - Jundiaí (...) se deu em 1868. A ela se seguiram a Mogiana, inaugurada em 1872 e a Sorocabana, inaugurada em 1875 . Esta última não se vinculou [primeiramente] ao café, mas sim à produção algodoeira que se desenvolveu na década de 1860, na área de Sorocaba. (Pessoa, 2003, p. 78) 


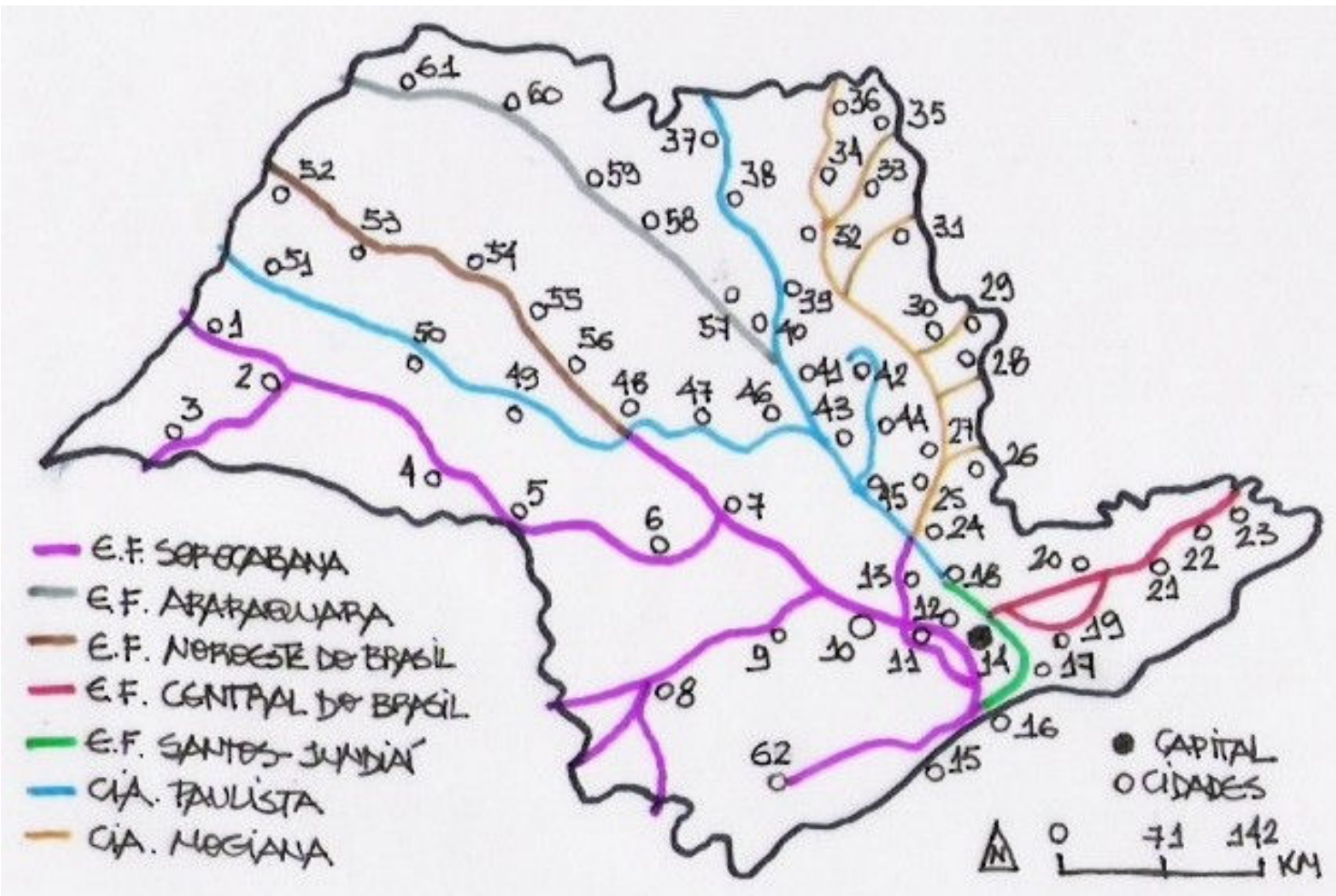

1. Presidente Venceslau

2. Presidente Prudente

3. Teodoro Sampaio

4. Assis

5. Ourinhos

6. Avaré

7. Botucatu

8. Itapeva

9. Itapetininga

10. Sorocaba

11. Mairinque

12. São Roque

13. Itu

14. São Paulo

15. Peruíbe

16. Santos

17. Paranapiacaba

18. Jundiaí

19. Mogi das Cruzes

20. São José dos Campos

21. Taubaté
22. Guaratinguetá

23. Cruzeiro

24. Campinas

25. Jaguariúna

26. Itapira

27. Mogi Mirim

28. São João da Boa Vista

29. São José do Rio Pardo

30. Casa Branca

31. Altinópolis

32. Ribeirão Preto

33. Batatais

34. Orlândia

35. Franca

36. Ituverava

37. Barretos

38. Bebedouro

39. Guatapará

40. Araraquara

41. São Carlos

42. Porto Ferreira
43. Rio Claro

44. Araras

45. Limeira

46. Brotas

47. Jaú

48. Bauru

49. Marília

50. Tupã

51. Dracena

52. Andradina

53. Araçatuba

54. Penápolis

55. Lins

56. Pirajú

57. Matão

58. Catanduva

59. São José do Rio Preto

60. Votuporanga

61. Jales

62. Registro

Croqui 12. Croqui da rede ferroviária do Estado de São Paulo.

Baseado em: Simielli, 1997; Setubal, 2004. Crédito: Andressa Celli. 
Ao mesmo tempo em que a ferrovia permitia a expansão da produção do café e da cana-de-açúcar, possibilitava o transporte de produtos manufaturados pelas primeiras indústrias, especialmente as de beneficiamento de algodão.

Podemos dizer, então, que o transporte por muar tinha sua capacidade limitada para o transporte. A “implantação das ferrovias passou a ser indispensável ao contínuo deslocamento do café [e de outras mercadorias, como o algodão]" (Pessoa, 2003, p. 65).

\section{De acordo com Monbeig,}

[o] traçado das ferrovias brasileiras não reflete em nada uma adaptação aos interesses coletivos. Ele foi dirigido por preocupações locais e políticas nas zonas de povoamento antigo. (Monbeig, 1985, p. 84)

Assim, foi fundamental para desempenhar esse papel do transporte a implantação das ferrovias paulistas, responsáveis por estruturar a nova rede de produção agrícola e industrial que se instalara no Estado de São Paulo. Segundo Schiffer,

[f]oi o traçado e a abrangência da rede ferroviária que induziram uma ocupação territorial contínua do interior paulista, possibilitando uma rede de cidades interligadas entre si e a capital e um escoamento sem entraves para a produção interiorana. (Schiffer, 1992, p. 34; apud Pessoa, 2003, p. 65)

De acordo com Prestes (2001), a Estrada de Ferro Sorocabana desempenhou o papel de distribuir a produção do algodão de Sorocaba que, "após esgotar o ciclo tropeiro (...) encontrou na transformação têxtil de sua produção algodoeira um novo caminho para o desenvolvimento" (Zimmermann, 1992, p. 148).

Segundo Zimmermann (1992), em 1920 a região de Sorocaba apresentava significativo desenvolvimento das suas bases industriais. Esse desenvolvimento estava apoiado na cultura do algodão que permitira a instalação de fábricas de tecidos no final de 1800 e início de 1900. Em 1920, Sorocaba apresentava mais 
estabelecimentos industriais que a região de Campinas, a qual estava ligada principalmente ao cultivo do café.

Porém, essa situação modificou-se mais tarde, pois, "apesar do alto ritmo de crescimento de sua indústria, a região de Sorocaba foi superada em 1940 pela de Campinas, região melhor situada nas transformações industriais pós-30". (Zimmermann, 1992, p. 149)

Na década de 1940, como veremos adiante, a região de Campinas foi atendida por uma rede de rodovias. Esse fato também estimulou ainda mais o crescimento dessa região em relação à de Sorocaba, que recebeu esse tipo de investimento somente com a construção das rodovias Raposo Tavares em 1954 e da Castelo Branco em 1967.

Assim, houve mais uma vez uma modificação no sistema de transportes, apoiado pelas necessidades da indústria e pela interferência de investimentos estrangeiros, agora norte-americanos. O tempo de sucesso do transporte ferroviário foi relativamente curto e logo

(...) quando os investimentos em infraestrutura no país passaram a ser financiados pelos Estados Unidos, por interesses políticos e econômicos, o transporte rodoviário passou a ser o foco no país. Surgiram os caminhões e começaram a se instalar, no Brasil, as primeiras estradas de rodagem, dando início à era rodoviária. (Pessoa, 2003, p. 104)

O Estado, com apoio mais uma vez do capital privado, incentivou a criação de uma rede regional de rodovias que atenderia principalmente o Estado de São Paulo. "O Governo implementou uma série de medidas de apoio a esse transporte, impulsionando acentuadamente o seu desenvolvimento" (Pessoa, 2003, p. 115).

Assim, de acordo com Pessoa (2003) e Zimmermann (1992), foram inauguradas nesse período as seguintes rodovias:

Rodovia Anhanguera - 1948 (liga São Paulo a Campinas e Igarapava)

Rodovia Presidente Dutra - 1951 (liga São Paulo ao Rio de Janeiro)

Rodovia Fernão Dias - 1954 (liga São Paulo a Belo Horizonte) 
Rodovia Raposo Tavares - 1954 (liga São Paulo a Presidente Epitácio)

Rodovia Castelo Branco - 1967 (liga São Paulo a Ourinhos)

Rodovia dos Bandeirantes - 1978 (liga São Paulo a Campinas e Cordeirópolis)

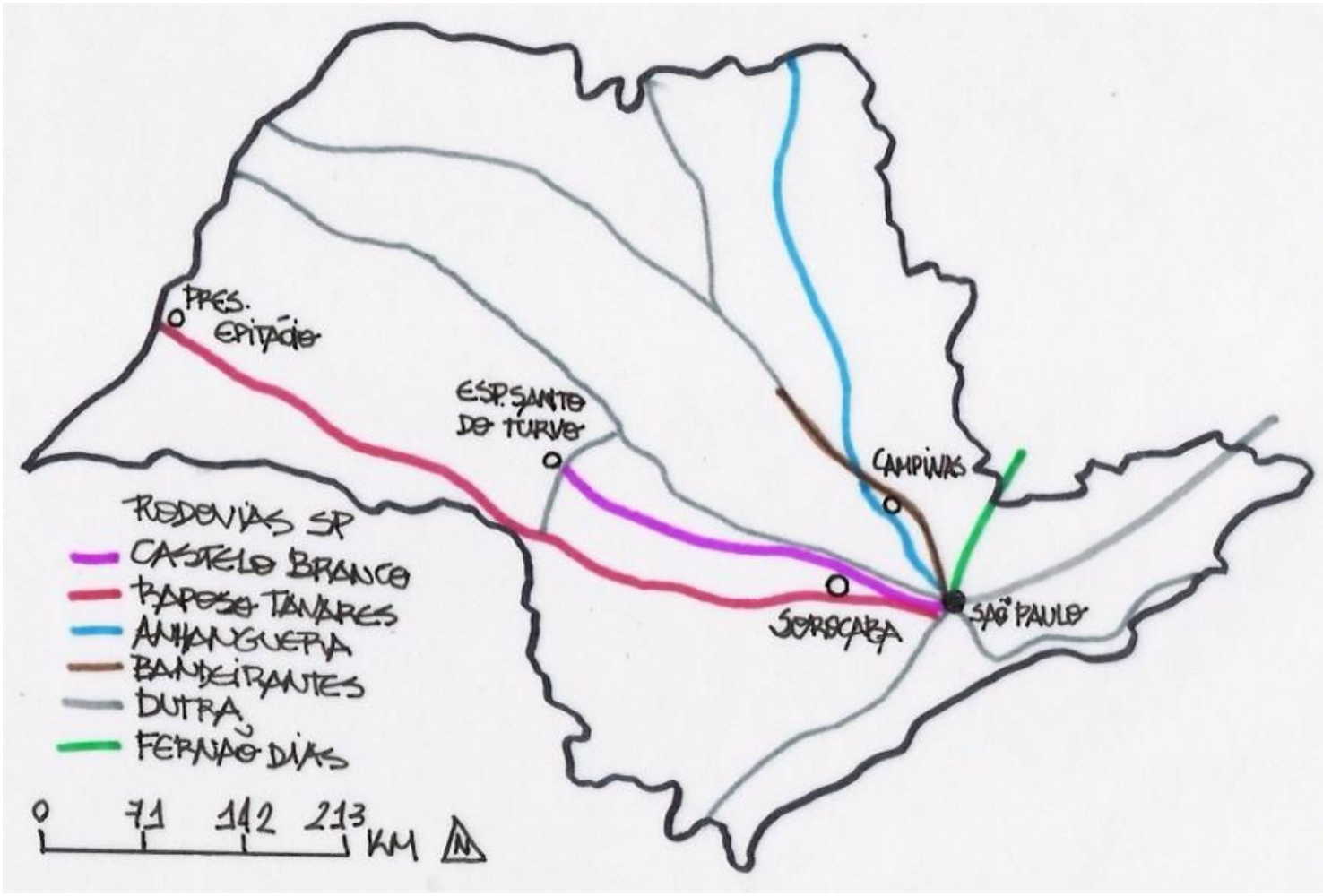

Croqui 13. Croqui da rede rodoviária do Estado de São Paulo.

Baseado em: Simielli, 1997. Crédito: Andressa Celli.

Segundo Pessoa (2003), com o objetivo de articular a comunicação das cidades produtoras de bens industrializados, as rodovias passaram a concorrer com os trilhos e a substituir a função das ferrovias como meio de transporte regional.

As características do transporte sobre rodas, assim como a acessibilidade diferencial criada pelas rodovias, foram aspectos importantes para a modificação verificada na estrutura regional e urbana do Estado de São Paulo. As estradas

(...) de rodagem articularam, de modo mais consistente, as regiões do país, ou seja, elas funcionaram mais eficientemente nas ligações entre regiões e até entre cidades, pois se organizaram em rede, ao contrário das ferrovias que tinham um sistema independente, somente ligando a região produtora a um porto exportador. (Pessoa, 2003, p. 106) 
Assim, com o fim do ciclo da ferrovia e a ascensão da era rodoviária, podemos dizer que

(...) o transporte não só seguiu o caminho de indutor do crescimento urbano e econômico, mas também passou a dar o suporte necessário ao crescimento (...) [ao proporcionar] um melhor atendimento público à população levando a uma maior qualidade de vida, e, consequentemente, ao aumento da população [urbana] e à formação de um mercado consumidor unificado, de proporções nacionais. (Pessoa, 2003, p. 124, 125)

De acordo com Pessoa (2003), o crescimento da malha rodoviária paulista foi concomitante ao crescimento industrial das cidades paulistas, este impulsionado pelo processo de interiorização do desenvolvimento industrial no Estado de São Paulo, estimulado pelo II PND ${ }^{6}$ (1974-1978).

Segundo Rocha Filho (1986), na região do Estado de São Paulo, foi concebido em 1977 e implantado em 1979 o Programa Especial de Cidades Médias, que desenvolveu políticas específicas para cada grupo de cidades, organizadas por áreas de influência e que obedeciam a diretrizes condizentes com um planejamento urbano territorial, a nível de interesses estaduais. O Governo estadual estabeleceu um plano específico com o intuito de incentivar a desconcentração industrial existente na capital e estimular o desenvolvimento industrial do interior paulista. Esse plano ficou conhecido como o processo da interiorização da industrialização, que acarretou em um grande desenvolvimento socioeconômico e urbano, nos anos 80, no Estado de São Paulo em cidades como Campinas, Ribeirão Preto e Sorocaba.

Dessa forma, em função desse programa estadual que estimulou significativamente o desenvolvimento das cidades do interior paulista, "os sistemas viários, de transportes e comunicações que se estabeleceram no Estado entre 1950 e 1980 continuaram a se expandir e a se aperfeiçoar até o final do século" (Reis Filho, V. 3, 2010, p. 28).

No âmbito das cidades paulistas, como resultado de um processo incentivado pelo Estado, porém, subsidiado pelo privado,

\footnotetext{
${ }^{6}$ De acordo com Rocha Filho (1986), o II PND - Segundo Plano Nacional de Desenvolvimento estabeleceu diretrizes para o desenvolvimento urbano nacional e industrial dos Estados de São Paulo e Rio de Janeiro. Foi aprovado pela Lei nº.151, de 4 de dezembro de 1974.
} 
[o] processo de industrialização também influenciou na evolução urbana, pois contribuiu para o aumento no ritmo de crescimento da população urbana, formando aglomerações mais complexas e agigantadas; transformando os velhos núcleos urbanos ou de localidades que anteriormente tinham outra função, em centros industriais; contribuindo para o aprimoramento de novos centros urbanos de atividade industrial e para a maior hierarquização dos centros. (Pessoa, 2003, p. 112)

O crescimento proporcionado pelo processo de industrialização foi tão significativo ao ponto das regiões de Campinas, Ribeirão Preto e Sorocaba destacarem-se em pouco tempo como grandes centros urbanos. Segundo Bacellar (1999; apud Pessoa, 2003, p. 105),

[e]ssa nova atividade [a indústria] desenvolveu-se em torno de quatro núcleos principais. O primeiro, e de longe o mais relevante, correspondia à atual Grande São Paulo, seguindo-se em ordem de importância, as regiões de Campinas, Sorocaba e Ribeirão Preto.

Como áreas metropolitanas, essas cidades tendem a continuar crescendo. Com base em nossa observação empírica, acreditamos que possa ser possível sua conurbação futura a partir das vias regionais que as interligam. Afinal,

[a]s alterações na estrutura industrial impuseram novo significado à urbanização. De um lado porque as transformações da própria estrutura produtiva, com a grande empresa e produção em escala, trouxeram consigo o crescimento do emprego industrial e a diversificação da estrutura social. De outro porque repercutiram sobre toda vida econômica, exigindo mudanças correlatas no mundo rural e no terciário das cidades. (...) Cresceram e modernizaram os serviços de transporte, de comunicações. (Cano, 1988 , ps. 57, 58) 


\section{Capítulo 2. Os caminhos como indutores do crescimento urbano de Sorocaba}

\subsection{Precedentes da formação de Sorocaba}

Segundo Frioli (2003) o espaço de assentamento de Sorocaba originou-se a partir de primitiva ocupação indígena tupiniquim, próximo ao morro de Araçoiaba, às margens do rio Sorocaba, no entroncamento da rota do Peabiru.

Apesar de estar cercada por outros espaços de assentamento em formação, a primitiva ocupação indígena de Sorocaba destacou-se em função de sua posição geográfica, condicionada pelas características do meio físico e de ligação em que se encontrava.

Sorocaba, em especial, encontrava-se no centro da rota que ligava a região sul e o litoral do Brasil. A "presença desse caminho levou à fundação do povoado de Sorocaba" (Taunay, 1939; apud Santos, 1999, p. 71).

De acordo com Santos (1999) tal característica, associada aos aspectos físicos relativos à sua posição geográfica, justificava a localização estratégica de Sorocaba a nível regional.

A ocupação primitiva de Sorocaba, constituída por tribos indígenas tupiniquins, localizava-se à margem desse ramal principal do Peabiru. Este, por sua vez, desmembrou-se em outros ramais menores, os quais interligavam as tribos que constituíam o primitivo espaço de assentamento de Sorocaba.

No croqui apresentado a seguir verificamos com maior clareza a relação existente entre a ocupação indígena e o viário constituído pelos ramais do Peabiru que passavam dentro do espaço de assentamento de Sorocaba. 


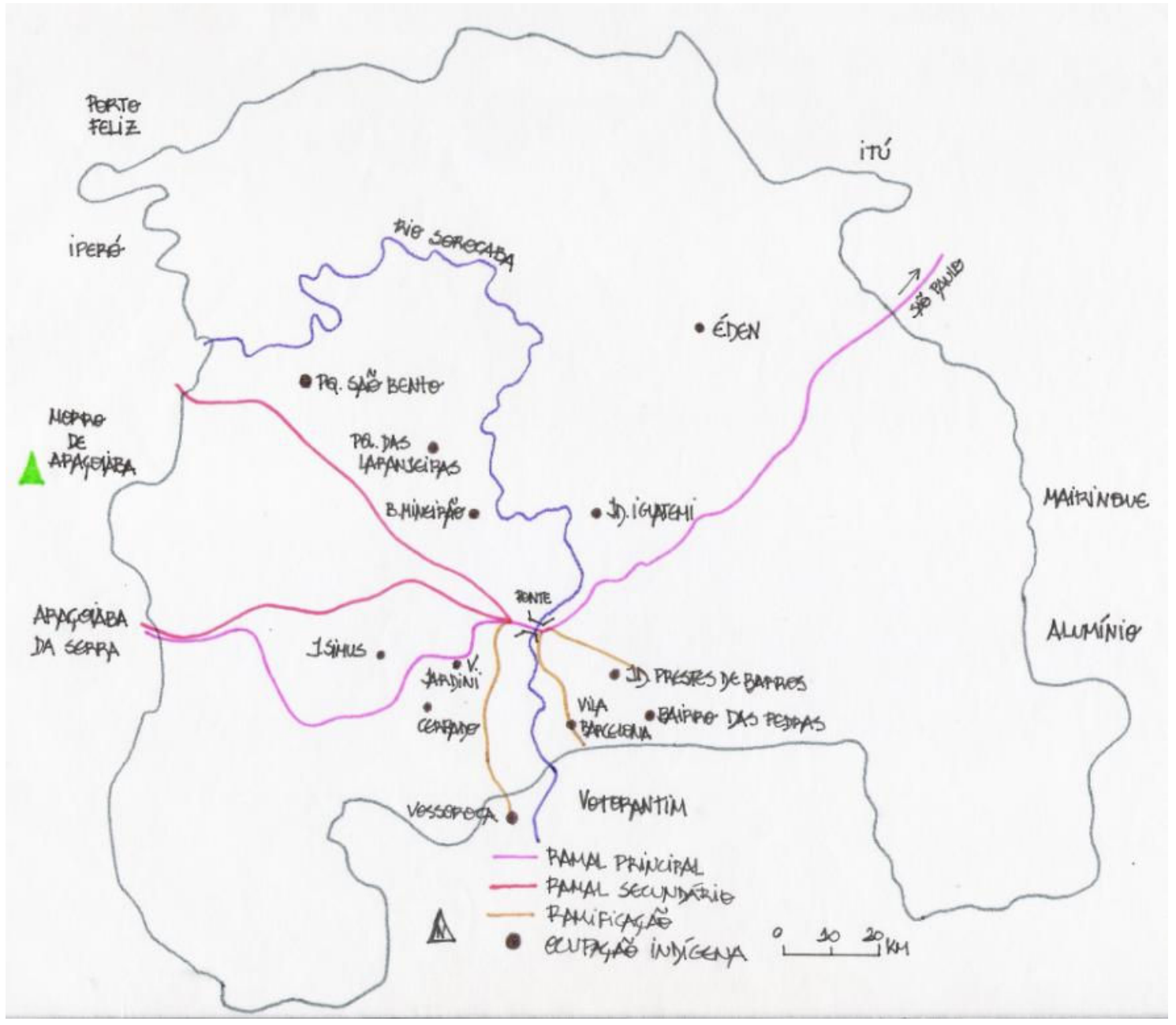

Croqui 14. Croqui da Ocupação Indígena e dos Ramais do Peabiru em Sorocaba.

Baseado em: Frioli, 2004 e Esquerdo, 1996, Apud Cruzeiro do Sul, 2004; Prefeitura Municipal de Sorocaba. Crédito: Andressa Celli.

Constatamos assim a importância dos caminhos do Peabiru na produção do espaço de assentamento de Sorocaba. (Jornal Cruzeiro do Sul, 2004, ps. 20, 21) Podemos dizer que Sorocaba foi marcada, desde o início do povoamento do seu território pela ligação, pela circulação de pessoas e de mercadorias, pelo comércio. Favorecida por essas condicionantes sócioespaciais regionais desenvolveu-se o núcleo urbano de Sorocaba.

Assim, no que concerne ao conjunto das relações de produção do espaço urbano, ou seja, do ponto de vista econômico e sócioespacial urbano, esses elementos tiveram papel significativo na formação e no desenvolvimento da 
estrutura urbana de Sorocaba. Essa configuração espacial determinou a constituição da malha viária e da ocupação do espaço urbano da cidade até os dias de hoje.

Ao analisar o desenho atual da área urbana de Sorocaba, constatamos muitas semelhanças com relação ao seu antigo desenho, no que concerne à ocupação e ao sistema viário. Notamos que a ocupação formada por algumas das tribos deram origem a núcleos urbanos dispersos os quais, ainda hoje, constituem bairros periféricos de Sorocaba. O Éden é um exemplo disso.

Em relação à malha viária de Sorocaba, vimos que o traçado das ramificações da trilha principal do Peabiru foi absorvido pelo espaço de assentamento, ou seja, esses caminhos permaneceram inseridos no atual desenho da cidade. Dessa forma, observamos que essas ramificações se transformaram em ruas e, mais tarde, em avenidas. Essa afirmação pode ser corroborada a partir da leitura da descrição e do croqui que seguem, respectivamente:

A trilha principal passava pela Aparecidinha, em direção a Sorocaba, seguindo a margem do rio Sorocaba até a rua Padre Madureira; desembocava na Avenida São Paulo e, depois de cruzá-lo, seguia pelas atuais ruas 15 de Novembro e de São Bento, praça Carlos de Campos, ruas 13 de Maio, da Penha e Moreira César, praça 9 de Julho, avenidas General Carneiro e Dr. Luiz Mendes de Almeida e daí em diante pela Estrada do Ipatinga. Ainda no traçado urbano atual, ocorriam trilhas secundárias em direção a diferentes pontos de Sorocaba e região: a estrada da Caputera (rua Pedro José Senger), Salto do Votorantim (início da rua Coronel Nogueira Padilha, ruas Newton Prado e Campos Sales) e Vossoroca (rua Artur Gomes, avenidas barão de Tatuí e Antonio Carlos Comitre) Havia dois caminhos, quase paralelos, em direção ao morro do Araçoiaba: um pelas ruas Souza Pereira, Hermelino Matarazzo e avenida Ipanema, bifurcando-se em direção ao morro e ao Itavuvu; outro pela praça Coronel Fernando Prestes, ruas Cel. Benedito Pires e Francisco Scarpa, praça da Bandeira e avenida General Osório. (Jornal Cruzeiro do Sul, 2004, p. 20) 


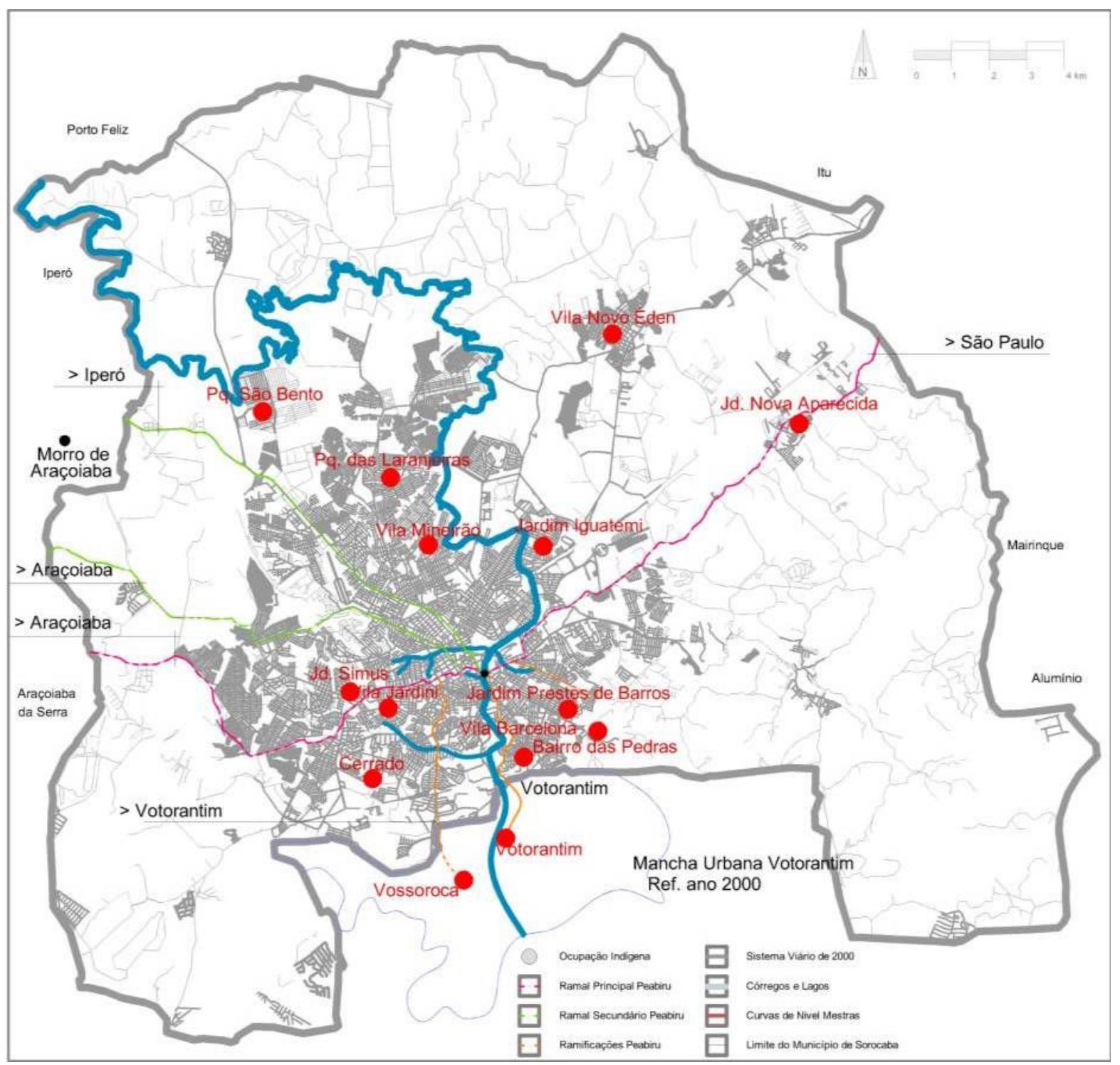

Croqui 15. Croqui da Ocupação Indígena e dos Ramais do Peabiru, sobreposto ao Viário Urbano de Sorocaba de 2000.

Baseado em: Frioli, 2004 e Esquerdo, 1996, Apud Cruzeiro do Sul, 2004; Prefeitura Municipal de Sorocaba. Crédito: Andressa Celli.

No entanto, antes de prosseguirmos nossa análise, é preciso esclarecer que, além da ocupação indígena, tiveram outras tentativas de povoamento na região que influenciaram diretamente a formação do espaço de assentamento de Sorocaba. Nesse caso, falaremos do início do povoamento branco na região, feito pelos colonos. 
Antes da constituição do povoado de Sorocaba formaram-se outros povoados ao seu redor, mais antigos, que não cresceram. Esse fato favoreceu em muito o desenvolvimento de Sorocaba.

Na verdade, “[o] povoamento [por colonos] da região de Sorocaba iniciou-se no final do século XVI, no morro do Araçoiaba, com as pesquisas e primeiras experiências siderúrgicas do continente americano, ali realizadas pelos dois Afonso Sardinha (pai e filho)" (Jornal Cruzeiro do Sul, 2004, p. 4).

Afonso Sardinha, em 1589, fez a primeira tentativa de produção de ferro no Brasil, com a construção de uma pequena fundição na região. A partir disso, formou um pequeno povoado, em 1599, chamado Nossa Senhora de Monte Serrat (Santos, 1999).

[A presença de minério no morro de Araçoiaba] deu origem, a partir de 1597, às primeiras atividades de industrialização do ferro nas Américas, desenvolvidas por Afonso Sardinha e gerou o primeiro povoado de pessoas de origem portuguesa na região do rio Sorocaba. (Jornal Cruzeiro do Sul, 2004, p. 13)

Essa investida ${ }^{7}$ na indústria de ferro, porém, não foi bem sucedida, culminando, consequentemente, na extinção gradual do povoado associado a essa indústria. Sendo assim, podemos dizer que o primeiro espaço de assentamento formado pelos Sardinha não prosperou, uma vez que era totalmente dependente da indústria de ferro.

No entanto, em seguida, houve mais uma tentativa de se constituir um povoado na região. "[E]m 1611 esse povoado [Monte Serrat] foi transferido para a beira do rio Sorocaba com o nome de São Felipe" (Santos, 1999, p. 71).

Porém, mesmo o povoado de São Felipe, conhecido também como Itavuvu, não prosperou. A localização desse segundo espaço de assentamento também não era adequada para o desenvolvimento do povoado.

\footnotetext{
7 Diferentemente desta, a segunda investida deu bons resultados - em uma época bem posterior, no século XIX, e com o apoio do rei D. João, quando foi criada a Real Fábrica de Ferro São João de Ipanema.
} 
Era preciso, para tanto, que o espaço de assentamento estivesse em uma posição mais estratégica, que favorecesse o desenvolvimento de uma função administrativa.

Baltasar Fernandes, fundador do povoado de Sorocaba (1654), tinha conhecimento dessa premissa. Tanto que, "embora tivesse conhecimento da existência do povoado de São Felipe [Itavuvu], escolheu um novo sítio na margem esquerda do rio Sorocaba" para a fundação da vila.

Esse sítio transformou-se no núcleo central do povoado de Baltasar Fernandes (Santos, 1999, p. 72). Além disso, as

\section{(...) sesmarias a ele [Baltasar Fernandes] doadas, ficavam exatamente no caminho percorrido pelos bandeirantes vindos de São Paulo, em suas viagens de caça aos índios nas missões jesuíticas. (Jornal Cruzeiro do Sul, 2004, p. 53)}

Sendo assim, podemos dizer que o fator que justificou o deslocamento do povoado para a outra margem do rio, apesar da sua difícil transposição, foi o de localização. Esse novo lugar permitiu que o povoado estivesse mais próximo da rota dos bandeirantes. Essa escolha de Baltasar Fernandes garantiu não só a sobrevivência do povoado, mas também - e principalmente - o seu desenvolvimento.

A partir dessas premissas é que Baltasar Fernandes fundou o povoado de Nossa Senhora da Ponte de Sorocaba (1654). Esta, por sua vez, demonstrou-se ideal para o desenvolvimento do espaço de assentamento que, em pouco tempo, constituiu-se Vila (1661). 


\subsection{Evolução Urbana de 1600 a 1700}

Como vimos, o ramal principal do Peabiru teve significativa influência na produção do espaço de assentamento de Sorocaba. Esse caminho, assim como suas ramificações, foi posteriormente utilizado como rota.

Tal como os índios, os bandeirantes souberam explorar a importante função comercial e de comunicação exercida pelas milenares rotas indígenas, as quais foram por eles mantidas e utilizadas ao longo de grande parte do território nacional.

Associado a esse fator, os bandeirantes souberam ainda aproveitar-se da estratégica localização de Sorocaba a nível regional. Como vimos no capítulo anterior, há semelhança entre o traçado das rotas do Peabiru e o das bandeiras.

Da mesma forma que os indígenas, os bandeirantes também utilizaram o rio Sorocaba como rota de penetração para o interior do Brasil. Por desaguar no rio Tietê, esse rio foi também um importante eixo de ligação e de transporte entre o sertão paulista e o Oeste do Brasil.

$\mathrm{Na}$ época das bandeiras, em função das necessidades de povoamento e exploração, essa ligação era feita principalmente com a região do Estado do Mato Grosso. Assim como as trilhas do Peabiru, o leito do rio Sorocaba foi também muito utilizado pelos bandeirantes como rota de comércio.

Notamos então que Sorocaba apresentou-se, nesse momento, como o centro desses eixos de ligação (trilhas e rio) e, com isso, transformou-se em uma paragem ${ }^{8}$ bandeirista. Esse caráter de centralidade que Sorocaba exercia perante as atividades das bandeiras é corroborado através da leitura do trecho seguinte:

[P]or quase um século de sua formação, Sorocaba foi um ponto de passagem das bandeiras, funcionando como uma espécie de posto avançado, base para incursões nos sertões. (Plano Diretor De Sorocaba, 1990, p. 24)

Sorocaba tornou-se, assim, uma importante paragem da rota de penetração e expansão bandeirista. Como assinala Prestes,

\footnotetext{
${ }^{8}$ Função essa que justificará, mais tarde, a fundação da Vila de Nossa Senhora de Sorocaba.
} 
Sorocaba (...) [fez] parte das rotas de penetração e expansão bandeiristas (...) da busca de metais preciosos, e da posse efetiva da terra do sertão paulista e ao longo dos caminhos do sul. (Prestes, 2001, p. 37)

Entendemos, dessa forma, que a afirmação de Sorocaba enquanto povoado deu-se, principalmente, em função da influência exercida pelas rotas das bandeiras e pelo comércio entre o Brasil e a região do Prata (Prestes, 2001).

Podemos dizer, então, que o caráter mercantilista de Sorocaba foi sempre característica predominante de sua ocupação.

Ao se transformar na Vila de Nossa Senhora da Ponte em 1661, logo após a fundação do povoado por Baltasar Fernandes em 1654, o espaço de assentamento de Sorocaba afirmou sua vocação para o comércio urbano transformando-se em uma importante paragem bandeirista.

Mas foi Baltasar Fernandes quem realmente instituiu a Vila de Nossa Senhora da Ponte de Sorocaba, ou seja, que fez levantar as construções essenciais para a criação desta.

A partir de 1654, quando Baltasar Fernandes se estabeleceu definitivamente em suas terras, concentrou a população dispersa da região ao redor do sítio onde fundou, em 1660, a capela de Nossa Senhora da Ponte.

Nessa época, Baltasar Fernandes trouxe para o povoado a ordem dos beneditinos e doou, "para garantir o futuro desenvolvimento do pequeno embrião urbano, (...) aos clérigos da Ordem de São Bento, a Igreja [capela] de Nossa Senhora da Ponte" (Santos, 1999, p. 73).

Além disso, doou uma vasta porção de terra próxima à capela "em troca da assistência espiritual e ensino aos moradores" da futura vila de Sorocaba (Jornal Cruzeiro do Sul, 2004, p. 54).

No ano seguinte ao da fundação da capela, efetivou-se a doação aos Beneditinos: o Mosteiro de São Bento foi erguido contíguo à capela de Nossa Senhora da Ponte. 
Dessa forma, verificamos que a partir dos croquis de 1661, apresentados na página a seguir, a estrutura urbana inicial de Sorocaba estava constituída. Como podemos notar, a partir da leitura de Baddini, nessa época

foi aberta a rua Boa Vista, ligando a residência de Baltasar Fernandes à Igreja. Também foi construída a ponte de madeira sobre o rio Sorocaba, abaixo da foz do Ribeirão do Moinho e na direção da capela, a fim de estabelecer a comunicação com as vilas do planalto, como Parnaíba e São Paulo. Em 1750, ela serviria para definir a localização do Registro de Animais, que seria instalado na sua embocadura, na margem direita do rio, em direção da saída para São Paulo. (...) Da capela até a ponte foi aberto um caminho, cujo trecho inicial seguia em linha reta na direção do rio Sorocaba, desviando-se levemente à direita para compor um outro trecho que, também em linha reta, iria alcançar a ponte. Na parte alta, próximo ao Mosteiro, passou a ser conhecido como rua São Bento; a partir de seu desvio para a direita, em direção à ponte, como rua da Ponte. Desde os primórdios da ocupação local, essas duas ruas representaram o [início do] núcleo urbano, a partir do qual se estruturou o traçado da cidade. (Baddini, 2002, ps. 99, 100) 
16. Croqui Viário e Ocupação Urbana de 1661 
17. Croqui Regional e Urbano de 1661 
Sendo assim, podemos dizer que não só as rotas das bandeiras tiveram relevância na constituição da vila de Sorocaba, mas também a ação de seu fundador, Baltasar Fernandes, responsável por planejar o desenvolvimento do povoado, transformando-o em vila.

Baltasar Fernandes planejou o desenvolvimento do povoado na medida em que instituiu o traçado viário e o modo de ocupação da vila. Quanto ao viário, utilizou-se dos antigos caminhos indígenas e da influência da rota bandeirista. Quanto à ocupação, estabeleceu sua configuração a partir do viário, concentrando os habitantes do povoado, as edificações e terras religiosas nas imediações dos caminhos principais.

De tal modo, o desenho do viário permitiu a centralização da ocupação, isto é, a concentração da ocupação urbana no centro da cidade, caracterizada pelo estabelecimento da população ativa e pela presença da Igreja. Esse caráter administrativo da vila permitiu o desenvolvimento do espaço intraurbano de Sorocaba, até agora incipiente.

Assim, podemos dizer que Sorocaba desenvolveu-se primeiramente a partir da influência regional de sua localização estratégica para, somente depois, desenvolver de fato o seu espaço interno, o intraurbano. Ou seja, sua importância regional é anterior à local. Sorocaba desenvolveu-se de fora para dentro e não de dentro para fora.

A forma administrativa que a vila ganhou, aos poucos atraiu mais moradores da região, antes dispersos, para ocupar o centro de Sorocaba ao redor da capela. Podemos dizer então que a instituição dos aparelhos ideológicos (educação) e políticos (Igreja e Estado), proporcionados por Baltasar Fernandes, fortaleceu o caráter administrativo da vila, garantindo, dessa forma, a afirmação da vila e de sua continuidade.

Assim, constituiu-se em definitivo a Vila de Nossa Senhora da Ponte, a consolidação da paragem. Nessa época a população era formada ainda por índios e bandeirantes. (Jornal Cruzeiro do Sul, 2004) 


\subsection{Evolução Urbana de 1700 a 1875}

Como vimos, de acordo com Prado Júnior (1956), o processo da mineração culminou com o desenvolvimento de toda a região centro-sul do Brasil. Ao mesmo tempo, desenvolveu uma rede de cidades ligadas a esse ciclo econômico com a ajuda dos tropeiros.

O meio de transporte, feito por muares, foi fundamental para otimizar a articulação desse processo, "contribuindo ativamente para a formação de um mercado urbano, de cujo desenvolvimento, ao mesmo tempo dependia" (Reis Filho, 1968, p. 50).

O ciclo do muar foi determinado pela necessidade de transporte de produtos entre duas regiões de destaque econômico - sul e oeste -, tendo sido Sorocaba a cidade articuladora desse comércio em função de sua posição central, entre essas duas regiões.

Essa característica de ponto de paragem e de sede da feira de muares proporcionou a Sorocaba um grande desenvolvimento socioeconômico. Podemos dizer que a sua produção socioeconômica estava associada, mais uma vez, à sua posição no mercado de âmbito regional.

$\mathrm{Na}$ época das feiras, especificamente, a população flutuante da cidade aumentava ainda mais. Segundo Santos (1999), vinha gente de todo o lugar, juntamente dos vendedores do Sul e dos compradores do Oeste, era a oportunidade para outros tipos de comércio, como os efetuados pelos relojoeiros, dentistas, artistas. Havia também muitas hospedarias na cidade, fato esse ocasionado pela dinâmica da feira.

Essas feiras, que aconteciam anualmente, também foram responsáveis pelo desenvolvimento de outras atividades, manufatureiras e de agricultura, voltadas ao abastecimento das tropas e dos estrangeiros que vinham realizar a negociação dos muares. De acordo com Bacellar (1994), por exemplo, 
[e]m Sorocaba, (...) muitas mulheres passavam boa parte do ano sozinhas em suas propriedades, cuidando dos filhos, casa, produção de subsistência e confeccionando artigos para os tropeiros, pois seus maridos partiam rumo ao Sul como tropeiros. (apud Straforini, 2001, p.27)

Esse fato, assim como outros, produziu um novo tipo de ocupação da cidade ao determinar novos estabelecimentos voltados ao urbano. Deu-se, também por esse motivo, a fixação de moradores urbanos em Sorocaba, interferindo na configuração socioespacial e na infraestrutura urbana ${ }^{9}$, com a criação de moradias para essa população.

Constatamos, dessa maneira, que o Tropeirismo e as pequenas culturas de Sorocaba incentivaram a manutenção e o desenvolvimento do comercio e, com isso, o trabalho livre e uma melhor distribuição de renda da população (Straforini, 2001, p. 91).

As atividades urbanas eram predominantemente executadas por pessoas qualificadas, as quais contribuíram em muito para o desenvolvimento de diversas técnicas novas, sobretudo nas oficinas.

Assim, podemos dizer que a influência regional da produção socioeconômica do tropeirismo permitiu o desenvolvimento de um tímido mercado interno em Sorocaba. Mesmo estando este associado ao mercado regional, observamos o surgimento de diversas atividades urbanas.

Mais uma vez, notamos o alcance dos deslocamentos regionais na formação do viário intraurbano, e este, na produção da ocupação urbana. Observamos, portanto, um notável crescimento da malha urbana de Sorocaba nesse período, em comparação com o anterior (Ver croquis de 1769).

\footnotetext{
9 "Outro mercado emergente era o dos serviços urbanos, como as linhas de bonde e a coleta de lixo, que começavam a surgir em nossas maiores cidades. Os primeiros coletivos usavam as mulas para movimentá-los e o mesmo faziam os carroções de coleta de detritos usados pelas prefeituras" (Baddini, 2002, p. 98).
} 
18. Croqui Viário e Ocupação Urbana de 1769 
19. Croqui Regional e Urbano de 1769 
Outro fato relevante para o entendimento da produção desse espaço urbano foi a disputa ocorrida entre a Câmara e o Mosteiro, por terras à margem do Rio Sorocaba, localizadas próximas ao núcleo urbano.

Como já foi dito, Baltasar Fernandes havia doado certa parte de suas terras aos beneditinos. A Câmara, porém, em função de seu interesse especulativo, tentou reaver para a cidade tais terras. Para termos uma ideia da importância desse fato, a rua da Constituição, ligando a margem do rio Sorocaba à rua Boa Vista, serviu para limitar os domínios desses terras, ou seja, as partes que cabiam à Câmara e ao Mosteiro. (Baddini, 2002, p. 113) Ainda, como assinala Baddini,

[e]ssa longa disputa de terras mostra que as margens do rio Sorocaba e do Ribeirão do Moinho orientaram o sentido de ocupação. Após a abertura da Estrada Geral, e principalmente depois da instalação do Registro de Animais em 1750, é que a ocupação se estendeu em direção às margens do Supiriri e para o Sul, por onde seguiam as tropas. (Baddini, 2002, p. 113)

Assim, a forte presença do Estado, centralizadora, utilizou-se das Câmaras para controlar a arrecadação de impostos e, consequentemente, regular o desenvolvimento das vilas e das cidades. Com a instituição do Rossio ${ }^{10}$, a administração da posse de terras passou a ser feita pela Câmara.

Dessa forma, constatamos que as condições de ocupação da vila eram influenciadas pela Coroa, porém, definidas pela Câmara ${ }^{11}$. Elas eram responsáveis pela elaboração de posturas municipais, as quais legislavam sobre diretrizes urbanas básicas que tinham como objetivo a orientação do crescimento urbano (viário e ocupação).

Nesse momento, em Sorocaba, a Câmara definia que "[o]s moradores ocupariam os terrenos em torno da Igreja e deveriam pagar um foro pelo lote, um aluguel, no arrendamento muito longo ou por perpetuidade" (Prestes, 2001, p. 43).

\footnotetext{
10 "Uma vez solicitadas as doações, as terras eram distribuídas pelas Câmaras, sob a forma de lotes na parte urbana propriamente dita, isto é, na parte central, e nas áreas extramuros ou mais afastadas, sob a forma de pequenas sesmarias, que iriam dar origem à formação de chácaras e pelas quais teriam especial interesse os conventos" (Reis Filho, 1968, p. 114).

${ }^{11}$ De acordo com Reis Filho (1968), a Câmara passou a ser responsável por novas atribuições: o desenvolvimento da rede urbana regional e da dinâmica das atividades do espaço urbano nessa época condicionou à Câmara o aperfeiçoamento de suas funções.
} 
Essas terras, que eram de patrimônio público, tinham como premissa serem destinadas apenas para o usufruto público e para fins de expansão urbana (Prestes, 2001, p. 44). No entanto, a Câmara utilizava-se de seu poder de Estado a favor da especulação imobiliária, desde a promulgação do Rossio.

Afinal, o interesse de alguns poucos prevalecia em detrimento de outros muitos. Desse modo, as terras que tinham melhor localização eram destinadas à elite da época. As terras da Igreja, assim como as do filho de Baltasar Fernandes, por exemplo, ficavam no centro de Sorocaba próximas à ponte do rio Sorocaba.

Assim, deu-se em Sorocaba o início da ocupação e divisão do terreno urbano, assim como a determinação do viário por posturas de arruamento instituídas pela Câmara. Ou seja, com o início do parcelamento do solo a partir do interesse da Igreja e do Estado, notamos a consolidação do espaço urbano de Sorocaba.

Nesse momento, cresceu também a importância da Câmara de Sorocaba que, incumbida de nortear o crescimento da cidade e, especificamente, o direcionamento do comércio, encontrou uma maneira de aumentar a arrecadação de impostos para a Coroa e aliados.

A Câmara foi responsável pela criação de uma rua destinada ao comércio de produtos de origem animal e vegetal, a rua da Quitanda. Nela, diversas "casinhas" foram construídas para abrigar esse tipo de comércio, o qual corresponde ao primeiro mercado municipal da cidade. Dessa forma, era possível o controle do comércio e, decerto, da arrecadação de impostos sobre as negociações efetuadas.

Além disso, a Câmara era responsável por gerir o Registro ${ }^{12}$ da ponte que, afora as taxas de rotina, exigia taxas extras aos seus usuários como justificativa de manutenção das feiras. Era necessário o investimento na infraestrutura desse comercio, ou seja, na manutenção da ponte e dos arruamentos.

Vale ressaltarmos esse fato uma vez que a localização e função do Registro influenciou de modo determinante a ocupação urbana, assim como o

\footnotetext{
${ }^{12}$ A Coroa, mais uma vez interessada na arrecadação de taxas e, da mesma forma pela pujança econômica de Sorocaba, institui na cidade uma espécie de pedágio pelo qual as tropas eram obrigadas a passar e pagar impostos. Esse pedágio era denominado Registro, o qual se localizava junto à ponte do rio Sorocaba, a primeira da cidade. (nota da autora)
} 
direcionamento do crescimento da cidade e de sua malha viária (Ver croquis de 1839). É possível observarmos isso também a partir da leitura do trecho abaixo:

Após a venda, as tropas precisavam cruzar a cidade para chegar ao Registro localizado logo após a passagem da ponte do rio Sorocaba. Como o núcleo urbano era tomado pelos comerciantes ambulantes, (...), as tropas não podiam passar pelas ruas já existentes. (Straforini, 2001, p. 85) 
20. Croqui Viário e Ocupação Urbana de 1839 
21. Croqui Regional e Urbano de 1839 
Assim, com o crescimento da cidade, os itinerários feitos pelas tropas tiveram que mudar de rota para desviar do centro do núcleo urbano (Frioli, 1983, p. 12; apud Straforini, 2001, p. 85). Mantinham, porém, a passagem pelo pedágio, que era obrigatória.

$1^{\circ}$ Itinerário

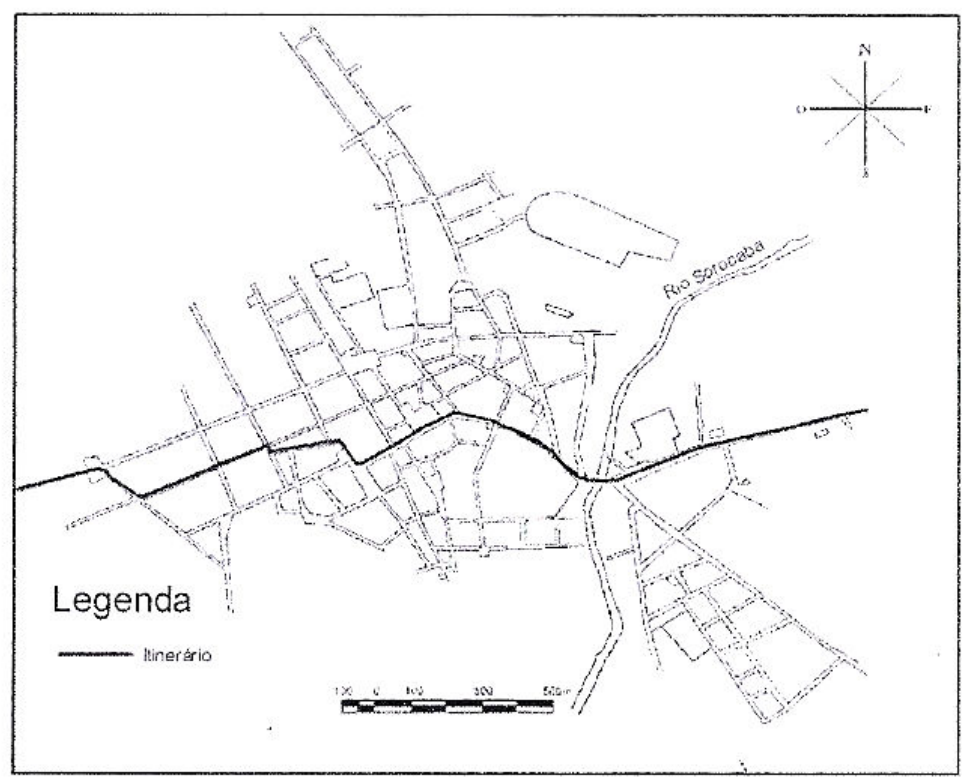

$2^{\circ}$ Itinerário

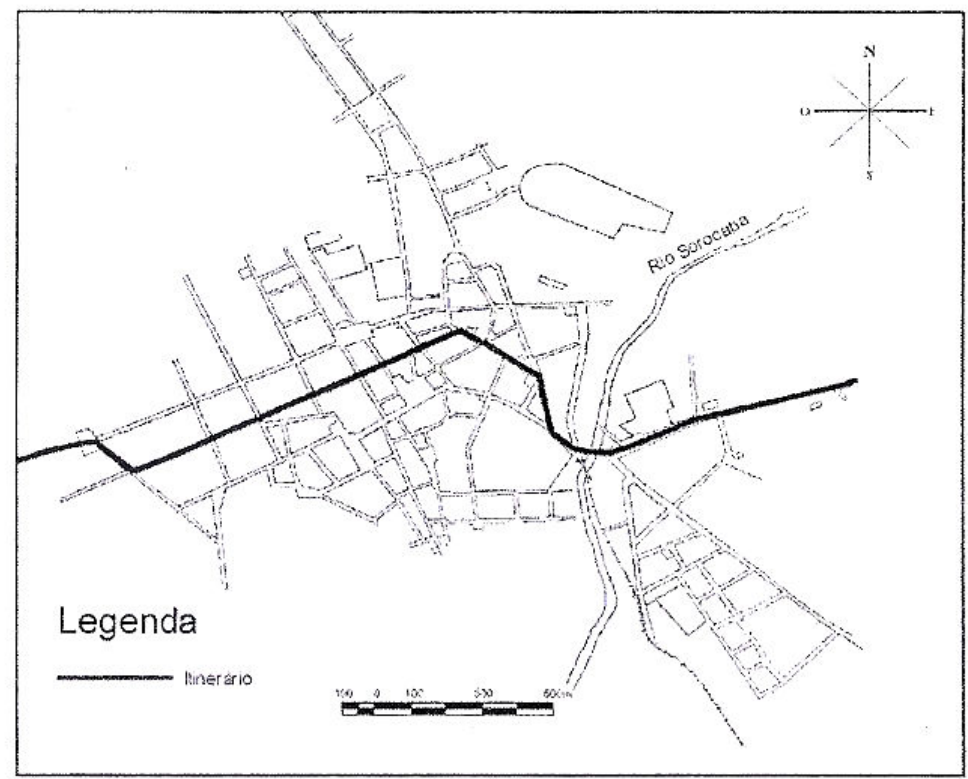

Figuras 4 e 5. Rotas muares Sorocaba. Adolfo Frioli, 1983; apud Straforini, 2001, p. 88. 


\section{$3^{\circ}$ Itinerário}

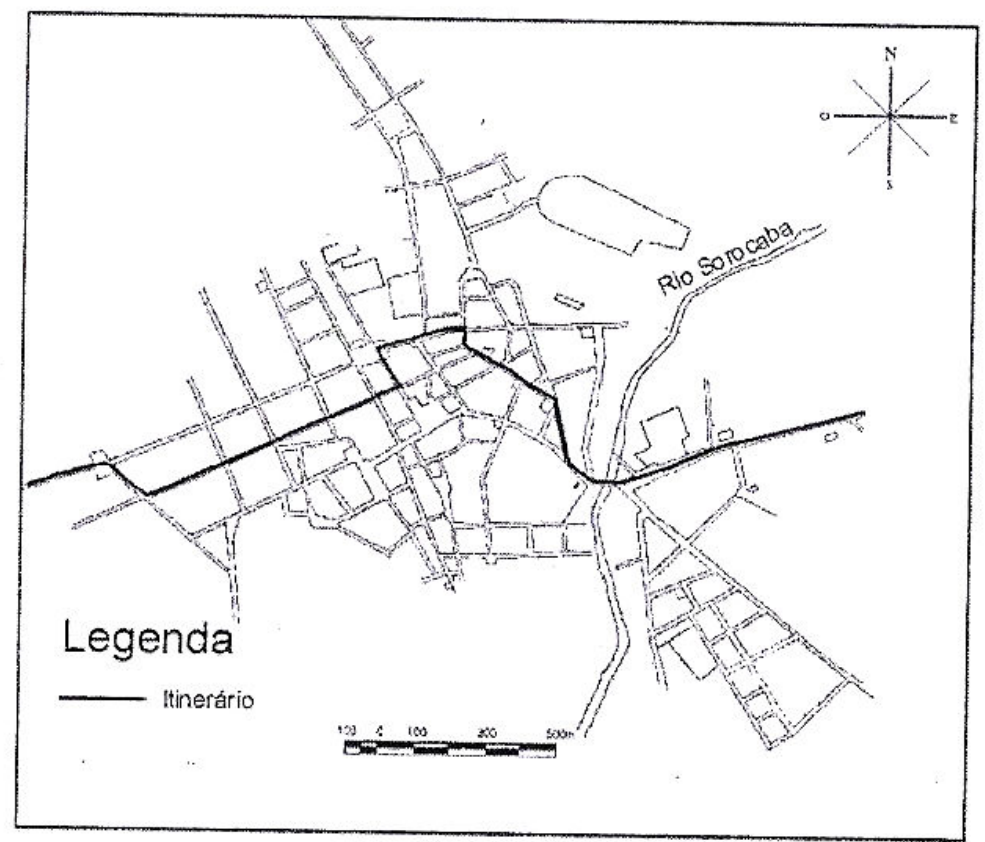

\section{$4^{\circ}$ Itinerário}

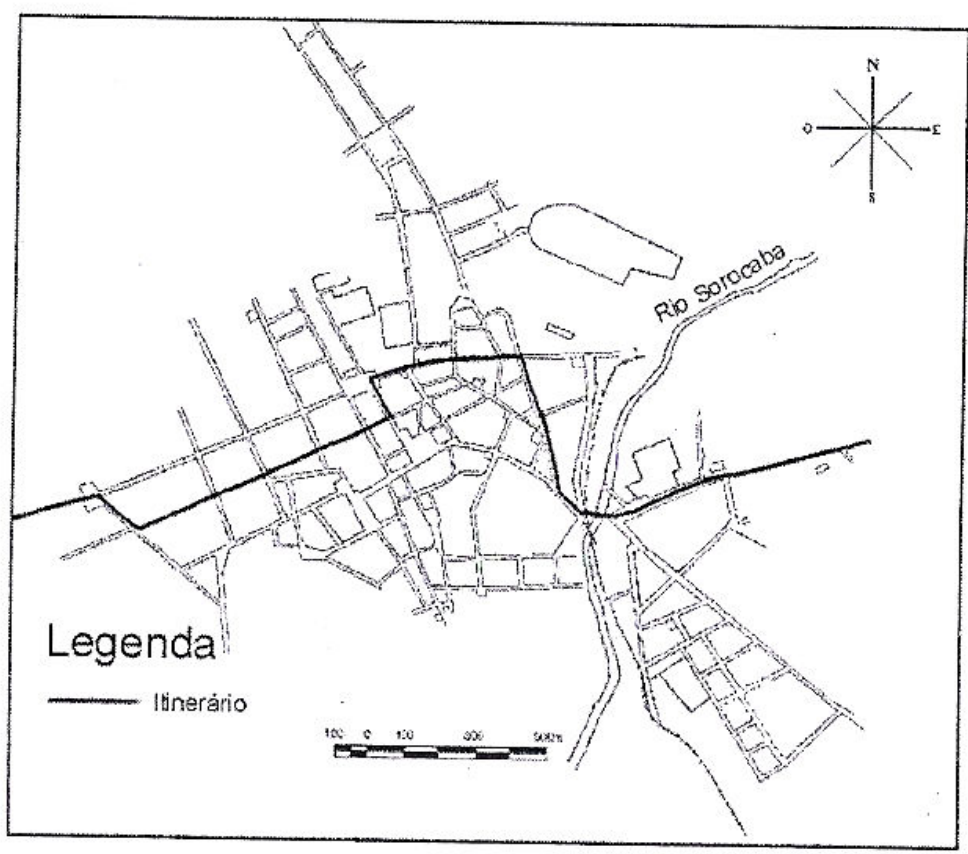

Figuras 6 e 7. Rotas muares Sorocaba. Adolfo Frioli, 1983; apud Straforini, 2001, p. 89. 


\section{$5^{\circ}$ Itinerário}

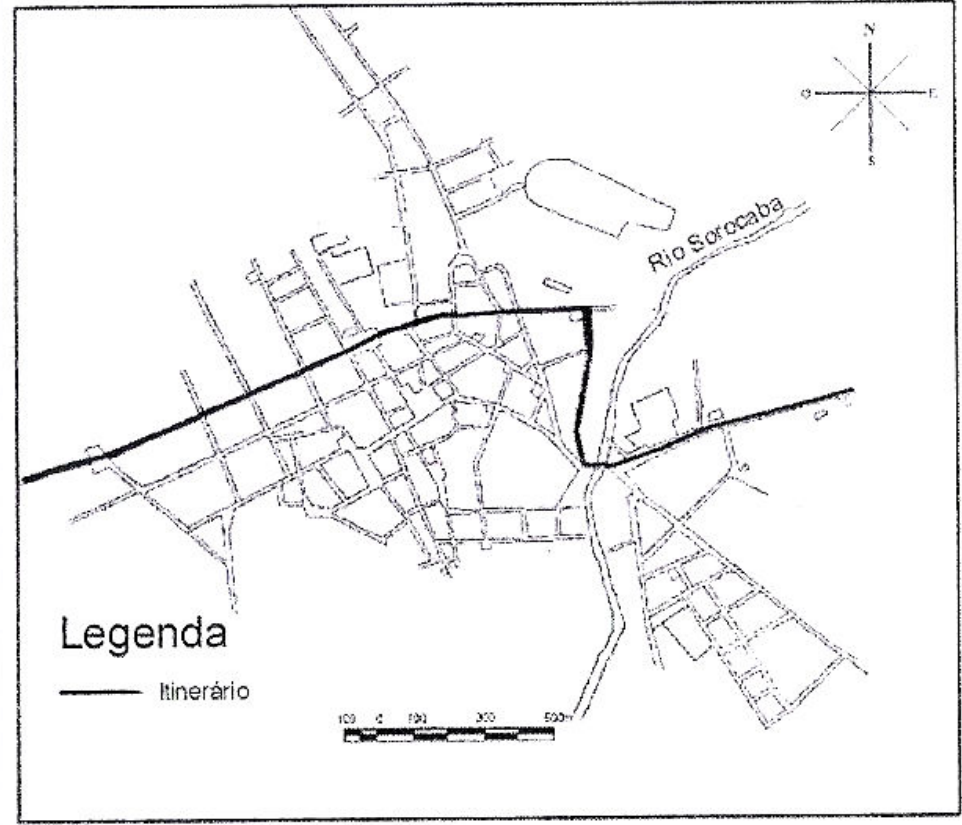

\section{$6^{\circ}$ Itinerário}

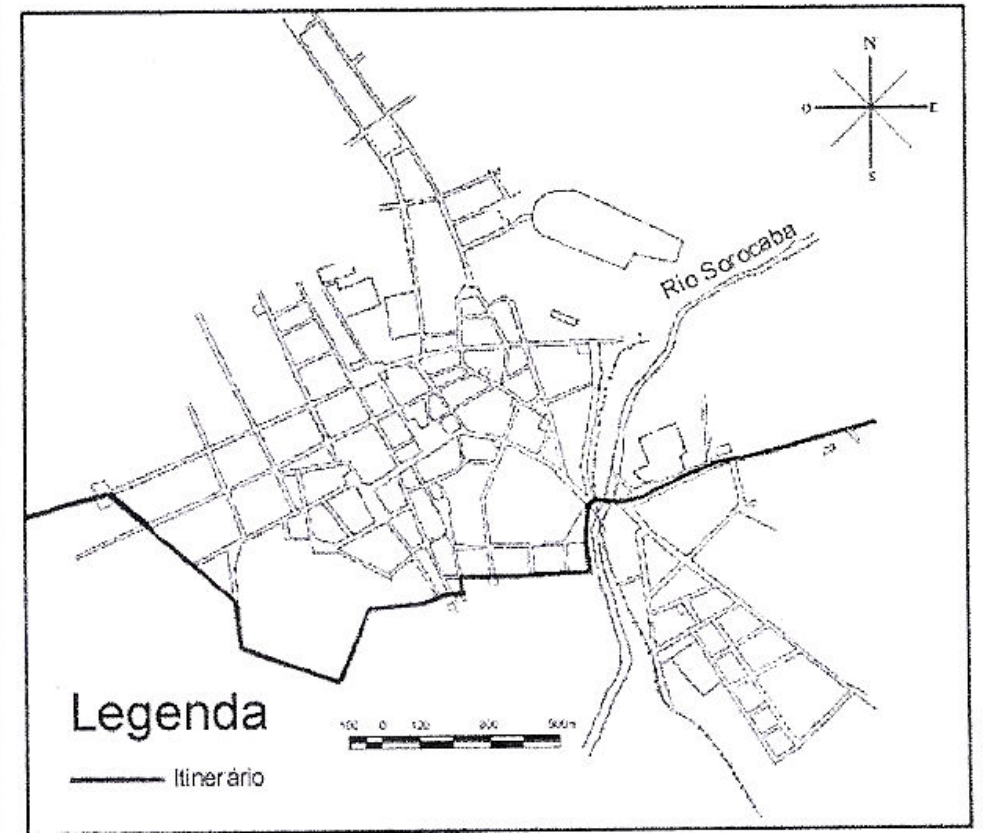

Figura 8 e 9. Rotas muares Sorocaba. Adolfo Frioli, 1983; apud Straforini, 2001, p. 88. 
Podemos dizer, então, que o desenvolvimento da estrutura urbana foi influenciado pela necessidade de mudança desses itinerários, uma vez que à medida que se estabeleciam novos caminhos, ruas eram abertas e, com elas, o comércio era estabelecido. Com base em Straforini,

[a]s alterações [do espaço urbano de Sorocaba] foram produzidas pelo e para o tropeirismo. Não apenas os animais se deslocavam para a periferia imediata, mas também todas as atividades urbanas. A abertura de novas ruas estimulava o acréscimo de novas ruas entre o novo e o velho itinerário, e nestas, novos estabelecimentos residenciais, comerciais e manufatureiros se instalaram. (Straforini, 2001, p. 86)

Novos caminhos eram formados ao redor do núcleo, no "subúrbio" da cidade e, consequentemente, novas ruas surgiram. Eram designados por itinerários planejados, não ao acaso.

Assim, em função dessa nova dinâmica instituída na cidade pelo tropeirismo, verificamos que a produção do espaço intraurbano foi direcionada pelo desenvolvimento do comércio e deslocamentos das tropas, pelas atividades urbanas e pela permanência de moradores na área urbana da cidade.

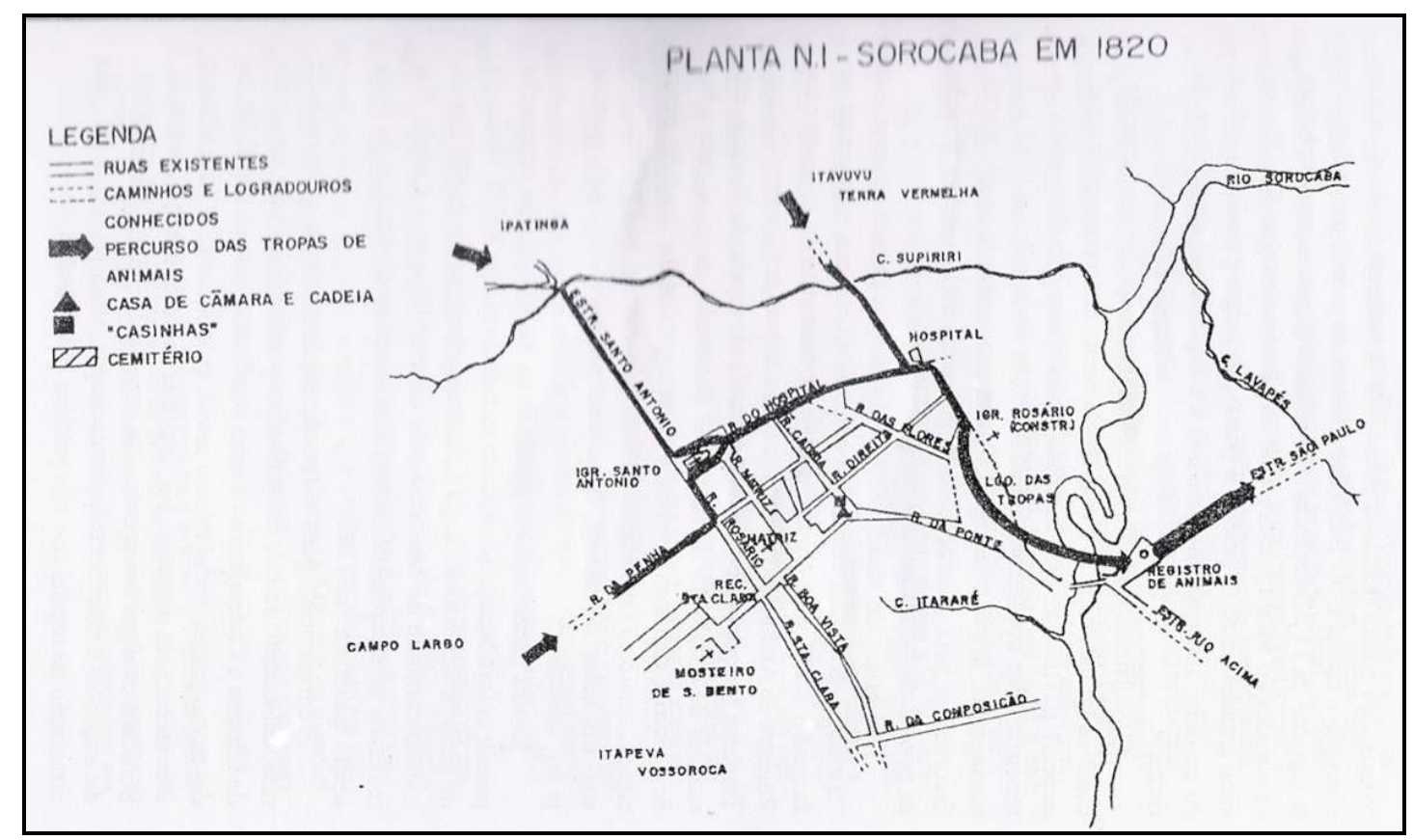

Figura 10. Croquis de 1820 mostrando a influência dos itinerários dos tropeiros no crescimento da malha viária da cidade de Sorocaba. Baddini, 2002. 


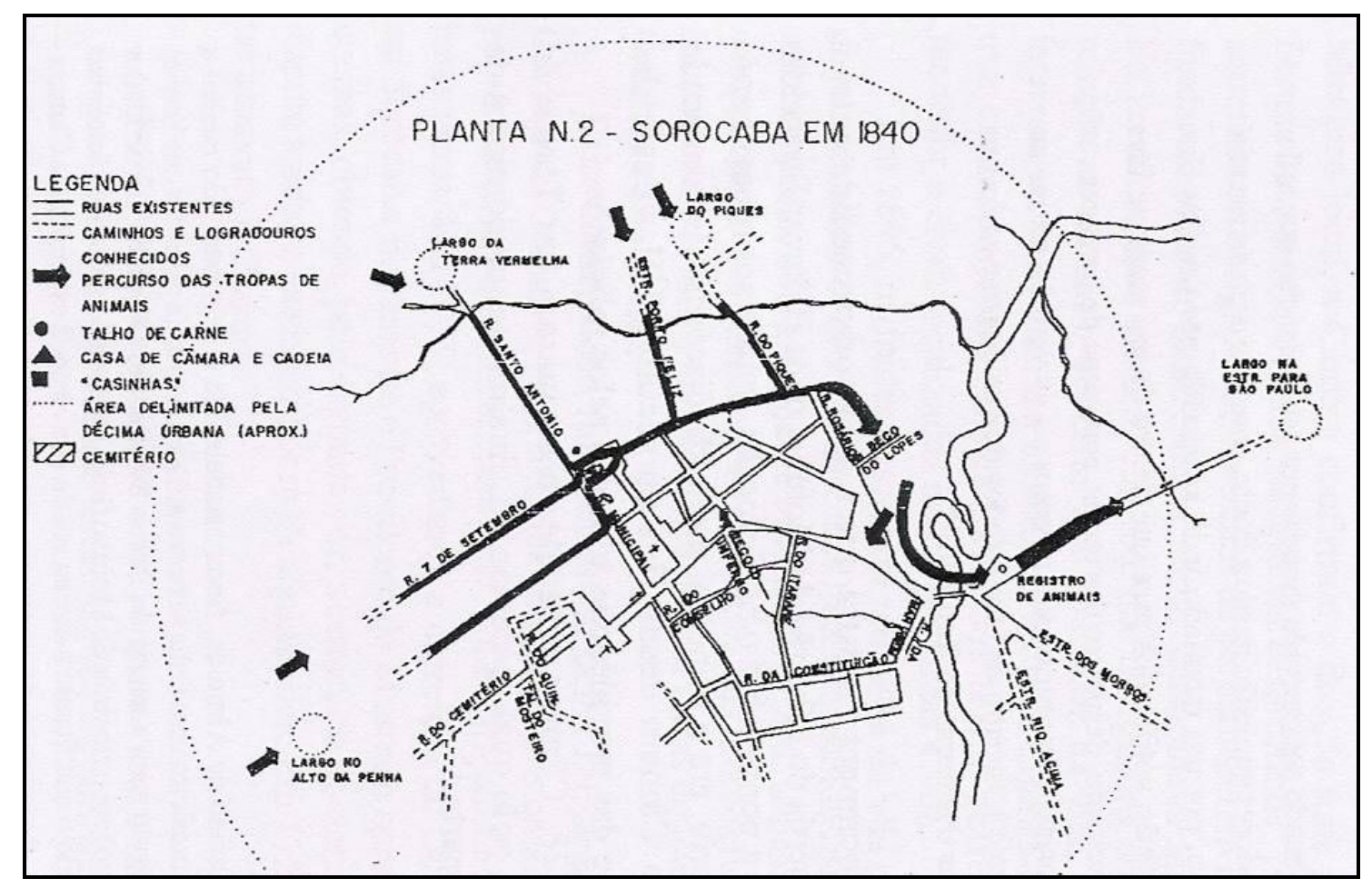

Figura 11. Croquis de 1840 mostrando a influência dos itinerários dos tropeiros no crescimento da malha viária da cidade de Sorocaba. Baddini, 2002.

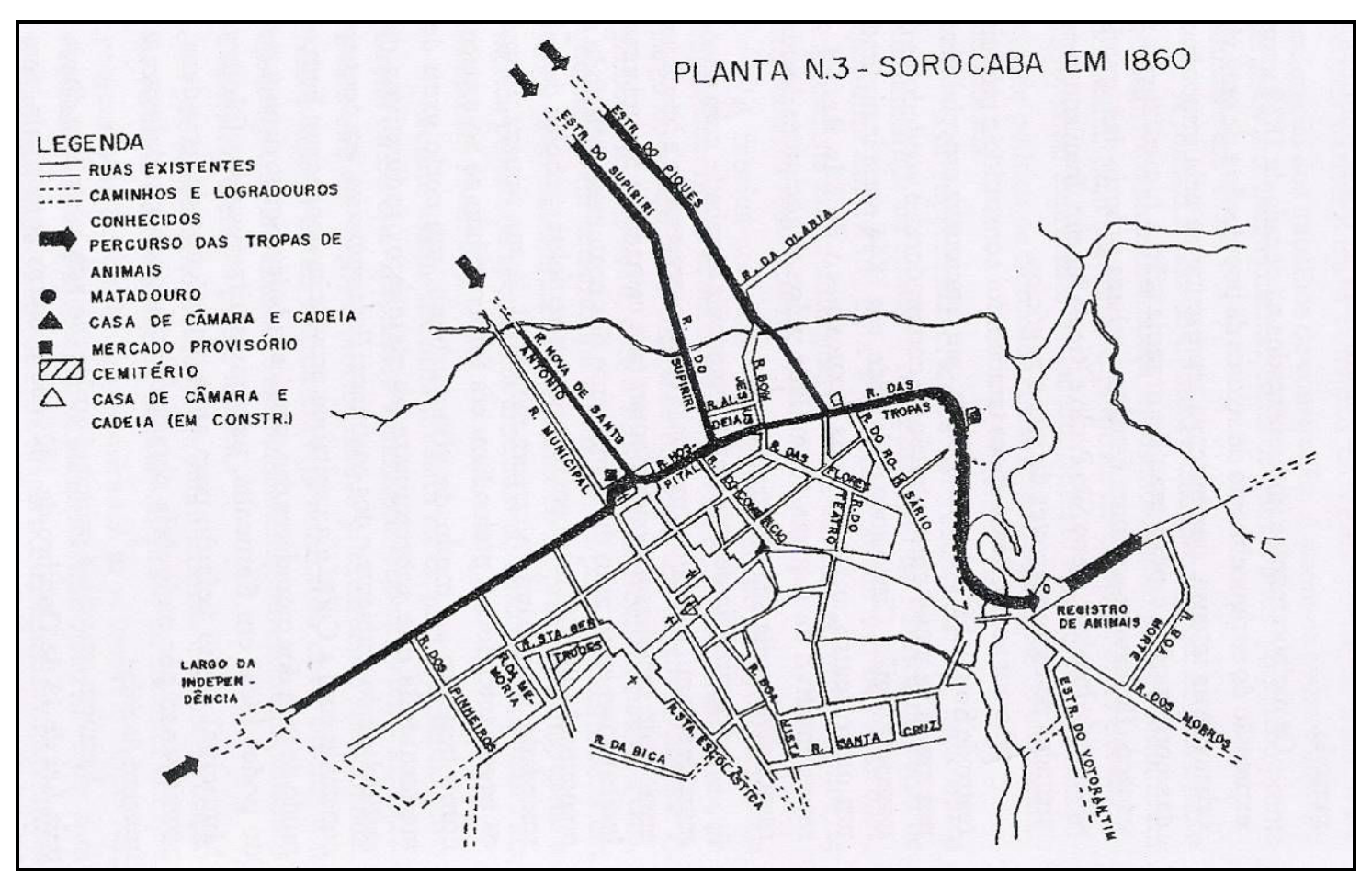

Figura 12. Croquis de 1860 mostrando a influência dos itinerários dos tropeiros no crescimento da malha viária da cidade de Sorocaba. Baddini, 2002. 
As feiras foram,

(...) a base econômica da vila de Sorocaba; no auge do ciclo do muar, Sorocaba foi elevada à categoria de cidade (1842). O muar havia participado no início do século XVIII no transporte de metais e produtos para sobrevivência dos mineiros; no princípio do século XIX, no surto cafeeiro, será o meio de transporte para alcançar os portos; no ciclo do açúcar e depois, do café em São Paulo, Minas Gerais e Rio de Janeiro, o muar transportará aos portos os produtos e trará sal e 'fazendas do mar em fora' (o que incluía também produtos importados diversos); serviu de correio e de meio de transporte para viajantes em geral; estabeleceu uma ligação entre o sul do nordeste do país.

O ciclo do muar em Sorocaba não se restringiu apenas ao ciclo do ouro. A última edição da feira de Sorocaba será em 1897, porém já um ciclo econômico decadente que desde aproximadamente 1860, estava sendo superado pela cultura do algodão e depois pela industrialização que se iniciaria em 1882. (Silva, 1995, p. 17)

De acordo com Prestes (2001), o Tropeirismo favoreceu o desenvolvimento do comércio no âmbito nacional e permitiu considerável acumulação de capital, gerando riqueza significativa tanto para a Coroa quanto para a rede de cidades conectadas ao processo mercantilista instaurado. O Tropeirismo proporcionou uma significativa modificação socioeconômica e espacial e, de acordo com Prestes,

(...) possibilitou, no Estado de São Paulo, o riquíssimo desenvolvimento da cultura do café [e de algodão em Sorocaba] (...) [possibilitando, mais tarde, o inicio da] industrialização da Província. Essa ocorrência, [é resultado do] capital acumulado pelo comércio das tropas. (Prestes, 2001, p. 73)

O Tropeirismo foi, então, responsável por formar uma base econômica forte capaz de propiciar o desenvolvimento de culturas agrícolas, como as do café e do algodão, que se espalharam por todo o Estado de São Paulo. O processo de produção dessas duas culturas fortaleceu ainda mais a dinâmica comercial desenvolvida pelo Tropeirismo.

Sorocaba, por sua vez, foi diretamente influenciada por esses fatores. Afinal, a cidade foi no Tropeirismo sede da feira de muares e um importante centro comercial. No campo, a criação de gado e muares, a produção de algodão arbóreo ${ }^{13}$,

\footnotetext{
${ }^{13}$ De acordo com Prestes (2001), o algodão arbóreo era utilizado para a fabricação de tecidos
} grosseiros em teares. Ele não era próprio para as fábricas de tecidos que viriam a se instalar em 
apoiavam as atividades urbanas. Em termos de sua manufatura, Sorocaba apoiavase na oficina de couro e na fabricação de acessórios de montaria, além da confecção de tecidos grosseiros feitos principalmente pelas mulheres dos tropeiros.

A iniciativa privada sorocabana teve papel fundamental nesse processo. Induziu a ampliação e qualificação da cultura de algodão e do seu beneficiamento, tinha como objetivo a instalação de fábricas de tecido em Sorocaba.

Manuel Lopes de Oliveira, que "foi o primeiro industrial do interior paulista e grande propagador da cultura do algodão", além de importante empreendedor de negócios em Sorocaba, instalou "em sua propriedade rural, uma pequena fábrica [de beneficiamento de algodão] em 1852, a Chácara Amarela, onde residia e cultivava as plantações de algodão [arbóreo]" (Prestes, 2001, p. 152).

Matheus Maylasky, assim como Manuel Lopes de Oliveira, também fazia parte de uma classe de empresários, representantes da iniciativa privada sorocabana. Maylasky sabia que, para desenvolver a produção de tecidos, era necessário melhorar a qualidade do algodão. Era preciso plantar o algodão herbáceo, próprio para a fabricação de tecidos de melhor qualidade, destinados à exportação.

Maylasky conhecia bem a técnica do cultivo de algodão herbáceo e da indústria têxtil. Desse modo, orientou os agricultores e industriais, através da imprensa, sobre o cultivo e preparo da matéria-prima para a produção de tecidos (Jornal Cruzeiro do Sul, 2004, p. 119). Afinal,

acostumados ao plantio e colheita de produtos destinados ao consumo interno, os lavradores encontravam dificuldade em se ajustar a um esquema de produção voltado para a exportação e o atendimento de indústrias situadas em outros países, exigentes em relação à qualidade. (Jornal Cruzeiro do Sul, 2004, p. 120)

Em 1870, "Sorocaba foi o centro de expansão da cultura de algodão herbáceo na Província e importante produtor de sementes" (Prestes, 2001, p. 151).

Sorocaba. Assim, a produção desse tipo de algodão foi aos poucos substituída pela do tipo herbáceo, introduzida por Matheus Maylasky. 


\section{Capítulo 3 A Ferrovia como indutora do crescimento urbano de Sorocaba}

3.1 Evolução Urbana de 1875 a 1930

Como vimos, segundo Prestes (2001), o cultivo, o transporte e a comercialização do café e do algodão, assim como o beneficiamento do algodão, gerou significativo desenvolvimento socioeconômico e espacial em algumas cidades paulistas, ligadas a essas duas culturas. Significa dizer que o processo de produção do café e do algodão gerou o desenvolvimento de atividades urbanas próprias desse processo. Esse fato favoreceu, posteriormente, a formação das bases industriais do Estado de São Paulo.

A condição ímpar de Sorocaba no Tropeirismo permitiu grande acúmulo de capital o que induziu o desenvolvimento da cultura de algodão. Com isso, houve a instalação de atividades urbanas, de comércio e de serviços, além de técnicas e manufaturas, ligadas à produção de algodão.

Diante desse panorama, Maylasky e Manuel Lopes de Oliveira, entre outros empresários sorocabanos, viram a necessidade de se desenvolver a produção de algodão em Sorocaba. Para isso, era necessário otimizar o transporte dessa produção, ainda feita pelos tropeiros. O transporte sobre trilhos era, para tanto, ideal para exercer essa função.

Segundo Gaspar (1930), por volta de 1870, criar-se-ia em Itu, próximo à Sorocaba, uma estrada de ferro. Alguns empresários sorocabanos tentaram participar dessa sociedade, porém, não houve acordo entre sorocabanos e ituanos.

Esses empresários sorocabanos (Luís Matheus Maylasky, Ubaldino do Amaral, Francisco Ferreira Leitão, Roberto Dias Baptista, Antonio Lopes de Oliveira), no entanto, não desistiram do objetivo de criar uma ferrovia que atendesse a cidade de Sorocaba. E, em 1871, criaram a Companhia Sorocabana, responsável pela construção da Estrada de Ferro Sorocabana, inaugurada em 1875. Tinham como objetivo

(...) baratear o transporte dos fardos de algodão e tecidos. Completamente livre de obrigações compulsórias para com o Governo 
e com meios financeiros próprios, pôde a iniciativa particular garantir seus trabalhos em Sorocaba e a continuidade indispensável para o estabelecimento de qualquer empresa. (Prestes, 2001, p. 152)

De acordo com Gaspar (1930) a Companhia Sorocabana era constituída de capital privado e recebeu incentivos por parte de acionistas da capital da Província, o Rio de janeiro, e do Governo da Província, que garantiu à Companhia Sorocabana $7 \%$ de juros sobre o capital investido.

Assim, podemos dizer que

a Sorocabana surgiu em função de uma dissidência de interesses entre grupos econômicos locais, que alijados de um ramal ferroviário que ligasse Sorocaba a Itu e Jundiaí e consequentemente ao Porto através da Santos - Jundiaí, desenvolveram esforços para a construção de uma ferrovia que atendesse aqueles interesses. A ideia era chegar ao porto de Santos, viabilizar uma economia de exportação e garantir o mercado inglês ressentido da falta do algodão por causa da guerra civil americana. (Silva, 1995, p. 35)

Ao mesmo tempo em que se instalava o transporte sobre trilhos em Sorocaba, diminuía-se a necessidade do transporte feito por muares, até então fundamental para a cidade de Sorocaba.

Podemos dizer dessa forma que, "com a modificação do meio de transporte (...), toda a vida comercial intensa [tropeira de Sorocaba] então existente foi desaparecendo" (Santos, 1999, p. 77). Consequentemente, a feira ${ }^{14}$ de muares foi sendo substituída aos poucos por outra atividade econômica - a produção de algodão, associada à nova dinâmica instaurada pela ferrovia.

Desse modo, impulsionada pela implantação da Estrada de Ferro Sorocabana e pela presença de capitais empreendedores, Sorocaba assumiu de fato "a atividade que já lhe era tradicional, a feitura de fios e tecidos de algodão" (Prestes, 2001, p.157). A cidade recebeu muitos estrangeiros nesse período, contribuindo assim para a qualificação da mão de obra local (Straforini, 2001, p. 117). Esse fato favoreceu a criação de uma classe de operários que atenderiam às futuras demandas das indústrias instaladas.

\footnotetext{
14 "Note-se também que o ano de 1897 marca o fim das feiras de muares em Sorocaba" (Silva, 1995, p. 24).
} 
Assim, podemos dizer que Sorocaba apresentava no final do século XIX características específicas às quais favoreciam a formação de bases para a implantação do processo industrial na cidade: a produção e beneficiamento do algodão, voltados principalmente para a exportação, uma ferrovia que ligava Sorocaba a São Paulo e, depois, ao porto de Santos e, finalmente, mão de obra qualificada, proveniente da grande quantidade de estrangeiros residentes em Sorocaba.

Tais bases, estabelecidas em Sorocaba, impulsionaram a implantação de fábricas têxteis por empresários sorocabanos, na cidade e na região. Sorocaba tornara-se

(...) um lugar ideal para a instalação das primeiras indústrias têxteis de São Paulo, não apenas por toda a infraestrutura física produzida pelas atividades ligadas ao Tropeirismo, mas principalmente, pela racionalidade técnica da sociedade. (Straforini, 2001, p. 117)

Assim, entre 1882 a 1913, como vemos nos croquis de 1888 e 1909, instalaram-se algumas fábricas de tecidos $^{15}$ nas proximidades da Estrada de Ferro Sorocabana.

\footnotetext{
15 "As grandes fábricas do período implantadas na cidade foram: Fábrica de Tecidos Nossa Senhora da Ponte, a 'Fonseca', em 1882, a Santa Rosália, em 189o, Santa Maria, em 1896, São Paulo, em 1909, Santo Antonio em 1913 e a Votorantim, em 1893" (Prestes, 2001, p. 156).
} 
22. Croqui Viário e Ocupação Urbana de 1888 
23. Croqui Regional e Urbano de 1888 
24. Croqui Viário e Ocupação Urbana de 1909 
25. Croqui Regional e Urbano de 1909 
O transporte por muares, apesar de ter sido suplantado pelo ferroviário, ainda era necessário para o transporte de mercadorias a nível local. Enquanto a ferrovia transportava as mercadorias produzidas pelas fábricas de tecido, a nível regional (o transporte da cidade até o porto de Santos), os muares eram responsáveis pelo transporte de outras mercadorias produzidas em Sorocaba e região até a estação ferroviária.

Esse fato fez com que a malha viária da cidade se desenvolvesse em função desses dois tipos de transporte. Notamos isso ao compararmos o crescimento da mancha urbana de 1839 com o de 1888.

Houve crescimento do viário nas proximidades da Estação Central da Estrada de Ferro de Sorocaba e em direção ao leito ferroviário, a noroeste da ponte de Sorocaba.

A mancha urbana também se desenvolveu ao longo dos caminhos regionais dos tropeiros: a oeste, na direção de Araçoiaba, a noroeste, perto da Fábrica de Tecidos Nossa Senhora da Ponte (de 1882) e a sudeste, nas proximidades da Chácara Amarela. Assim, além de reforçar os caminhos já existentes nessas direções, constituídos pelos tropeiros, novas ruas foram formadas; induzindo o crescimento do viário e da ocupação urbana.

Constatamos, ao analisarmos os croquis de 1888 e de 1909, que as fábricas de tecidos localizavam-se nas proximidades da linha férrea e da estação ferroviária central, já que facilitaria o transporte local das mercadorias até os vagões de trem.

Podemos afirmar que a ocupação de caráter industrial ocorreu nas proximidades da estação ferroviária central e dos ramais constituídos pelo leito da ferrovia. Vemos nos croquis de 1909 que ao lado das fábricas formaram-se loteamentos urbanos. A instalação das fábricas têxteis induziu a formação de vilas operárias em seu entorno, a norte e noroeste. Tal ocupação favoreceu a expansão urbana da cidade nas imediações das fábricas de tecidos, principalmente no entorno da estação ferroviária central e da linha férrea.

É preciso salientar que, entre os anos de 1888 e 1909, o trajeto da linha férrea sofreu algumas modificações. Os croquis de 1888 apresentam somente um leito que parte da estação ferroviária central em direção a São Paulo. Já nos croquis de 1909 
vemos que foi criado um novo trajeto na direção oeste, que parte da estação ferroviária central e que se liga ao trajeto que vem de São Paulo. Além disso, criouse um caminho na direção sul para atender a instalação da Fábrica de Tecidos de Votorantim, que data de 1893.

Assim, em função da localização das indústrias e das vilas operárias, notamos nos croquis de 1909 que a expansão urbana consolidou-se na direção das terras do outro lado da linha férrea e do rio Sorocaba: caracterizaram a ocupação e a formação dos bairros do Além Linha e do Além Ponte (Ver croquis 1909).

Com base nos croquis de 1909 vemos que o início da industrialização proporcionou à Sorocaba um forte impulso econômico e, consequentemente, significativa expansão urbana. Surgiram novos bairros espraiados no Além Ponte, Além Linha e Cerrado. A estrutura urbana tornou-se cada vez mais complexa e, assim, já em 1925, notamos um grande crescimento da mancha urbana. 
26. Croqui Viário e Ocupação Urbana de 1925 
27. Croqui Regional e Urbano de 1925 
Podemos dizer então, de acordo com Santos (1999, p. 86), que a industrialização levou crescimento à cidade. E, com isso, acarretou em transformações na ocupação do solo e na distribuição da população na cidade. Ainda, de acordo com Hardman,

(...) se historicamente, as cidades preexistiram às indústrias, ocorreria que a partir do momento em que o capital industrial chegou a dominar todas as demais atividades econômicas, ele passou também a determinar toda a expansão urbana. (Hardman, Francisco Foot. Trabalho Urbano e vida operária. In: Mendes Jr., Antonio \& Maranhão, Ricardo (org.) Brasil História, texto e consulta: Hucitec, p. 276, cap. LXXV; apud Silva, 1995, p. 66)

Ainda, de acordo com Silva, a industrialização "será a responsável pela ampliação da cidade, não apenas ampliando ruas, mas criando [e consolidando] bairros operários para a massa de proletários que movimentam a futura Manchester Paulista" (Silva, 1995, p. 54).

Assim, ao analisarmos os croquis de 1925 em comparação aos de 1909, vemos a consolidação e crescimento das vilas operárias: Vila Carvalho, Vila Angélica, Vila Santana, Vila Rosália, ao norte e noroeste; Vila Hortência, Vila Santa Maria, a sudeste; Vila Independência, Vila Fonseca, a oeste.

O crescimento urbano deu-se ao norte e noroeste (Além Linha), a sudeste e leste (Além Ponte), em função das atividades ligadas à industrialização. Houve também um significativo crescimento na direção oeste e sudoeste (Cerrado), para além do Centro.

Ainda, comparando-se os croquis de 1909 e 1925, notamos uma nova modificação $^{16}$ no trajeto da linha férrea, em parte do leito que corre da estação ferroviária central em direção a São Paulo. Em 1909, o leito do trem estava localizado do lado esquerdo do rio Sorocaba. Já em 1925, foi feito um novo traçado do lado direito do rio Sorocaba.

\footnotetext{
${ }^{16}$ Acreditamos que a mudança do leito ferroviário no sentido de São Paulo tenha sido feita em função de alguma necessidade técnica, relativa ao próprio funcionamento do trem. Não encontramos registros que justifiquem essa mudança no percurso.
} 
Notamos que foi mantida uma pequena ramificação do leito ferroviário que atendia a Fábrica Santa Rosália. Vale salientar também que a ponte ferroviária de travessia do rio também se deslocou na direção sul.

Apesar da modificação da posição do leito ferroviário em relação ao rio Sorocaba, notamos que as vilas operárias ao norte continuaram a se expandir na mesma direção de antes. Da mesma forma, a região agora atendida pelo novo leito ferroviário apresentou a mesma direção de crescimento, a sudeste e a leste, no ano seguinte de nossa análise (Ver croquis de 1939). Em ambas as regiões já haviam fábricas de tecidos instaladas que, ao nosso ver, foram indutoras do crescimento das vilas operárias em seu entorno e, consequentemente, da mancha urbana. 


\subsection{Evolução Urbana de 1930 a 1954}

No fim do século XIX, em função da significativa produção de algodão em Sorocaba, ocorreu o desenvolvimento da economia industrial no município de Sorocaba. O "surto algodoeiro na cidade poderia ter dado outro desenvolvimento às atividades manufatureiras [mas], ao contrário[,] facilitou a fixação industrial em Sorocaba" (Silva, 1995, p. 26). De acordo com Silva, a economia

(...) mercantil sorocabana 'expande-se', de um mercado interno (nacional) com os negócios nas feiras de muares, para a exportação do algodão, conseguindo assim, a ascendência de uma burguesia comercial ou mesmo agrário-comercial que não havia se destacado anteriormente dentro do tropeirismo. (Silva, 1995, p. 39)

Da mesma forma, criaram-se condições para a ampliação do mercado interno, que já havia sido constituído na época do tropeirismo, mas que ainda não era consumidor de bens industrializados: Afinal, a

(...) preponderância do capital comercial é, em primeiro lugar, o resultado do desenvolvimento ainda fraco das relações de produção capitalistas do Brasil. (Silva, Sérgio. Expansão cafeeira e origens da

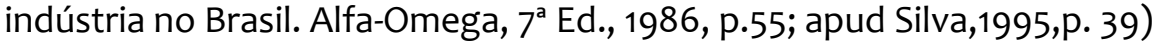

Podemos dizer, assim, que "Sorocaba representava essa (...) sociedade baseada em atividades urbanas, produzindo uma nova racionalidade preparada para receber o capital industrial" (Straforini, 2001, p. 109).

A partir de 1930, além de novas fábricas associadas à indústria têxtil, surgiram em Sorocaba outras fábricas de beneficiamento de matérias-primas de extração, como o caso do calcário, abundante no solo da região. Iniciou-se então o processo do calcário, transformado em cimento e outros derivados como a cal, feito pela fábrica Votoran em 1936 (Santos, 1999, p.83).

É preciso ressaltar, desse modo, que não foi somente a indústria têxtil que se aproveitou da conjuntura socioeconômica que dispunha Sorocaba. "Outros ramos 
da indústria, pouco a pouco, vieram ampliar esse parque fabril” (Santos, 1999, p. 84). Assim, com o surgimento em Sorocaba dessas novas fábricas, houve, a partir de 1930, a consolidação das indústrias de caráter agroexportador na cidade. De acordo com Santos, sobressaíram-se

as indústrias Votorantim, por agruparem fábricas de natureza variada e algumas delas complementares entre si, com tendência a concentração vertical: além de cimento e cal, fábricas de fiação, tecelagem, estamparia, papel celofane, óleos vegetais, sabão. Visando racionalizar a produção, a grande empresa procurou ampliar suas atividades com o aproveitamento total da matéria-prima. Assim, trabalhando com algodão, aproveita os resíduos para produzir óleos vegetais e sabão; possuindo grandes áreas rurais ricas em calcário, passou a explorar a indústria de cal e cimento. (Santos, 1999, p. 84)

Em função do crescimento industrial da indústria de cimento em Votorantim, foram inauguradas duas usinas hidrelétricas próximas a essa indústria, construídas "em trechos encachoeirados do rio Sorocaba". Uma em 1937, na Fazenda Santa Helena, e outra em 1940, no município de Piedade (Santos, 1999, p. 85). Assim,

(...) a fácil obtenção de energia hidráulica, aliada a outros fatores (...) mão de obra abundante e barata, tradição têxtil e fácil comunicação entre os centros abastecedor, produtor e distribuidor - garantiram a sobrevivência, continuidade, e mesmo o desenvolvimento da indústria têxtil em Sorocaba, a despeito do extraordinário crescimento de outros centros industriais no interior do Estado, bem como daqueles que vieram a se estabelecer na capital paulista. (Santos, 1999, p. 85)

É preciso enfatizar também o papel da indústria metalúrgica. Essa indústria teve destaque nesse período "quando alguns técnicos e operários alemães recémchegados resolveram dedicar-se a esse ramo de atividade. Fundaram então a Fábrica Metalúrgica Nossa Senhora da Aparecida" (Santos, 1999, p. 83) (Ver croquis de 1939). 
28. Croqui Viário e Ocupação Urbana de 1939 
29. Croqui Regional e Urbano de 1939 
Além dessa investida no ramo da metalurgia, houve a exploração de jazidas no morro de Araçoiaba. “Em 1937, a Serrana S.A. de Mineração conseguiu concessão dessas minas para produzir adubos fosfatados. Assim estabeleceu-se a indústria de fertilizantes, aproveitando-se de algumas instalações da antiga Fábrica de Ferro Ipanema" (Santos, 1999, p. 83).

Em função dessas alterações na economia e na dinâmica da cidade ocasionadas pelo crescente incentivo do município e do Estado de São Paulo à produção das indústrias agroexportadoras, verificamos grandes transformações nas direções do crescimento urbano de Sorocaba. Notamos isso ao compararmos os croquis de 1939 e 1952. 
30. Croqui Viário e Ocupação Urbana de 1952 
31. Croqui Regional e Urbano de 1952 
Assim como em 1925, as mesmas direções de crescimento da mancha urbana de Sorocaba continuam a existir. Porém, a expansão de algumas dessas regiões, como nas direções norte e sudeste, foi bastante intensa. Verificamos ainda que em função do desenvolvimento das atividades industriais na cidade, havia outras direções de crescimento da mancha urbana, também significativas para a nossa análise.

O crescimento na direção da região noroeste tornou-se notável nos croquis de 1939 e de 1952. Essa expansão urbana foi provocada pela criação nessa direção de oficinas da Sorocabana. Criou-se, assim, um loteamento em seu entorno, a Vila Barão.

Observamos, também, um significativo crescimento urbano na direção da região sul e sudoeste do município, no sentido de Votorantim. Nesse distrito de Sorocaba, como vimos, estavam instaladas uma fábrica de tecidos, uma de calcário, duas usinas hidrelétricas, além de e, também, uma vila operária.

A proximidade dessa área com o centro de Sorocaba, aliada a um eixo de ligação estabelecido desde os tropeiros, fortalecido agora por um ramal ferroviário que se ligava à estação central de Sorocaba, foram fatores que também contribuíram para o crescimento da mancha urbana de Votorantim, na direção norte, e a do centro de Sorocaba, na direção sul.

Notamos, desse modo, que a expansão urbana de Sorocaba está intrinsecamente relacionada à localização da estação central de ferro que, próxima ao centro da cidade, direciona o estabelecimento das indústrias e das atividades urbanas ao seu redor. Podemos dizer, assim, que a estação ferroviária central de Sorocaba foi responsável pela polarização das atividades urbanas nas suas imediações. A descrição desse processo em Sorocaba pode ser ilustrada a partir da análise feita por Marx, reproduzida no trecho abaixo.

E a locomotiva representou, também, uma nova etapa no desenvolvimento das cidades que alcançou. Tanto pela porta que abriu a estação ferroviária - como pelo impacto desta no tecido urbano pré-existente. Atingindo uma povoação, a estrada de ferro não dispensava suas exigências de trajeto; o seu leito buscava acompanhar as curvas de nível, impunha igualmente um determinado terreno para a estação. E se convertia num obstáculo difícil de transpor, num atrativo para as instalações fabris e para os 
grandes armazéns ao longo de seus trilhos, num pólo de gravitação a partir das plataformas de embarque. Esse pólo, muitas vezes periférico e distante, passou a competir com o centro urbano, complementando-se ou mesmo suplantando-o. Deixou marca indelével na evolução urbana brasileira, de pouco mais de um século para cá. A nova porta aberta trouxe o sucesso, o crescimento e a riqueza para algumas concentrações urbanas do país em detrimento de outras. (...) Os poucos pontos de cruzamento dessas ferrovias com as ruas tronaram as suas porteiras congestionadas pelo tráfego local e viram florescer nas suas proximidades o comércio e os serviços. (Marx, 1980, p. 114)

Ao mesmo tempo, ao longo da estrada de ferro, verificamos que "a ocupação urbana como um todo seguiu, concomitantemente, à implantação da ferrovia" (Pessoa, 2003, p. 86). Principalmente, a ocupação pelas indústrias, as quais, como vemos em Sorocaba, localizavam-se ao lado do eixo do transporte ferroviário.

Essa "constante" da paisagem urbana, e que também se aplica à de Sorocaba, foi ilustrada por Monbeig:

(...) as primeiras indústrias [contribuem] para a criação de uma paisagem urbana, favorecendo uma primeira tendência à formação de bairros. Colocam-se nos lugares mais favoráveis, nas entradas da cidade, para quem vem das zonas de desbravamento, e sobretudo perto da estação, ao longo da estrada de ferro. Como procuram os terrenos menos valorizados, os seus edifícios são construídos de frente para a aglomeração inicial, do outro lado da ferrovia, até então poupado pelo crescimento urbano (...) As Vilas, que se abrem em torno dos estabelecimentos industriais, atraem os operários, por estarem próximos dos seus locais de trabalho e pelo custo de terrenos e dos aluguéis, menos altos que na cidade. (Monbeig, 1984, p. 360) 


\section{As Rodovias como indutoras do crescimento urbano de Sorocaba}

Evolução urbana de 1954 a 2000

Segundo dados do SEADE analisados por Zimmermann (1992), Sorocaba foi um dos municípios que mais se destacaram no processo de industrialização do Estado de São Paulo. Com índices que competem com Campinas, Ribeirão Preto e Vale do Paraíba e que variam de acordo com o período analisado, podemos afirmar que Sorocaba tornou-se de fato uma das sedes da interiorização da indústria paulista.

De acordo com Zimmermann, nos anos de 1920, o capital produzido pela indústria sorocabana já era bastante significativo em comparação com o capital gerado por outras cidades do Estado de São Paulo. A região de Sorocaba era mais desenvolvida, por exemplo, do que a região de Campinas. Sorocaba ficava apenas atrás da capital São Paulo (1992, p. 148).

“Entretanto, apesar do alto ritmo de crescimento de sua indústria, a região de Sorocaba foi superada em 1940 pela de Campinas, região melhor situada nas transformações industriais pós-[19]30" (Zimmermann, 1992, p. 149). Esse quadro prosseguiu até meados de 1950: “por todo o período da industrialização restringida, o crescimento econômico e urbano de Sorocaba e região foi positivo (...), porém com menor intensidade que o das outras regiões interioranas" [Campinas, Ribeirão Preto, Vale do Paraíba] (Zimmermann, 1992, p. 150).

No período seguinte, que se iniciou em 1954 e que se estende até os dias atuais, instalou-se "a grande indústria de bens de consumo duráveis no país" (Cano, 1992, p. 129). E de acordo com Zimmermann (1992, p. 169), junto com ela, implantou-se uma política nacional de transporte sobre pneus, substituindo, paulatinamente, o transporte sobre trilhos. Assim, em Sorocaba,

(...) a partir de 1956 e por toda a década de [19]70, sob a influência da nova dinâmica econômica, a indústria [de Sorocaba e] da região se diversifica, estimulada pela implementação do Plano de Metas e pela inauguração da Rodovia Raposo Tavares (1954) [e da Castelo 
Branco (1967)]. Nessa etapa, a indústria regional ingressa num novo estágio marcado pela produção de bens intermediários, de capital e de consumo duráveis, em parte fruto da diversificação de grandes grupos locais na exploração mineral da região. (Zimmermann, 1992, p. 151)

Podemos dizer desse modo que, esse desenvolvimento industrial estimulou o crescimento urbano de Sorocaba. A intensa dinâmica socioeconômica e espacial em que se encontrava a cidade nessa época resultou na criação de leis municipais que tinham o objetivo de regulamentar o desenvolvimento urbano de Sorocaba.

Em função disso, em $1961^{17}$ (Lei $n^{\circ} 837$ ) o município promulgou uma lei que dispunha sobre a instituição de uma comissão para a criação do plano diretor de Sorocaba - embora já houvesse uma regulação do crescimento urbano da cidade datada de $1949^{18}$ (Lei $n^{\circ}$ 129). Em seguida, em $1962^{19}$ (Lei $n^{\circ}$ 907), criou-se um escritório técnico para a comissão do plano diretor com o intuito de desenvolver o primeiro plano diretor da cidade. Essa comissão tinha por objetivo coordenar o planejamento territorial do município.

Não é difícil entender a importância da composição dessas leis, nesse momento. Afinal, como podemos verificar na análise dos croquis de 1962, a mancha urbana de Sorocaba dessa época apresenta um significativo crescimento em comparação com a mancha urbana de 1952. Vemos ainda que esse crescimento se dá em todas as direções. Nota-se um grande desenvolvimento da estrutura urbana.

\footnotetext{
${ }^{17}$ Lei $n^{\circ} 837$, de 1961 (revogada pela lei no 1885/1976), que dispõe sobre instituição da comissão do plano diretor do município (Prefeitura Municipal de Sorocaba).

${ }^{18}$ Lei no ${ }^{129}$, de 1949 (revogada pela lei nº 869/1961), Código de Obras e Zoneamento, que fixa pontos centrais para delimitação do círculo das terras devolutas municipais (Prefeitura Municipal de Sorocaba).

${ }^{19}$ Lei no 907, de 1962 (regulamentada pela Lei no 1043/1963), que Dispõe sobre criação do escritório técnico da comissão do plano diretor do município, e dá outras providências (Prefeitura Municipal de Sorocaba).
} 
32. Croqui Viário e Ocupação Urbana de 1962 
33. Croqui Regional e Urbano de 1962 
Em 1963, deu-se continuidade à elaboração do plano diretor. A equipe técnica concluiu o Relatório SAGMACS nessa data. Esse documento discorria sobre as bases do plano piloto, aprovado também em $1963^{20}$ (Lei $n^{\circ} 1194$ ). Em 1964, foi apresentado o primeiro plano diretor de Sorocaba à Câmara. Esse relatório foi recusado pelos vereadores da época.

A partir do projeto de lei de 1964, foi elaborado um novo texto, cuja aprovação foi efetuada em $1966^{21}$ (Lei $n^{\circ}$ 1.438). Na sequência, o plano diretor foi complementado pelo Código de Obras (Lei $n^{\circ} 1437$ ), Código de Zoneamento (Lei $\mathrm{n}^{\circ}$ 1541) e Lei de Arruamento de $1966^{22}$, “com a delimitação de zonas de uso, cada uma delas acompanhada de uma lista de atividades permitidas e com uma considerável Zona de Expansão Urbana23", (Santoro e Cymbalista e Nakahima, 2005, p. 6).

A partir da década de 1960 verificamos, então, o destaque do papel do Estado, representado agora pelo município, na estruturação urbana de Sorocaba.

A legislação instituída pelo município através de planos diretores que regulamentavam o crescimento urbano da cidade, com base em normas de arruamentos e zoneamentos influenciará, como veremos na sequência, na configuração do sistema viário de Sorocaba.

(...) Artigo 35 - Junto às estradas de ferro e rodovias de $1^{\mathrm{a}}$ categoria ou especiais (Especificações do Departamento Estadual de Estradas de Rodagem) e ainda junto aos cemitérios, é obrigatória a abertura de vias públicas nos lados, com largura não inferior a $14 \mathrm{~m}$ (catorze metros), exceto quando se tratar de topografia que não o permita, a critério da Prefeitura.

Artigo 36 - Junto as linhas de transmissão de energia elétrica, é obrigatória a abertura de vias públicas em um dos lados, com largura não inferior a $14 \mathrm{~m}$ (catorze metros), exceto quando se tratar de topografia que não o permita, a critério da Prefeitura.

\footnotetext{
${ }^{20}$ Lei n ${ }^{\circ} 1194$, de 1963, que dispõe sobre aprovação do plano piloto do desenvolvimento do município de Sorocaba, e dá outras providências (Prefeitura Municipal de Sorocaba).

${ }^{21}$ Lei $n^{\circ} 1438$, de 1966 (vide leis $n^{\circ}$ 2008/1979, $n^{\circ}$ 2211/1983 e $n^{\circ} 2324 / 1984$ ), que dispõe sobre a aprovação do plano diretor do município de Sorocaba e dá outras providências (Prefeitura Municipal de Sorocaba).

${ }^{22}$ Lei $\mathrm{n}^{\circ} 1417$, de 1966, aprova o código de arruamento e loteamento (Prefeitura Municipal de Sorocaba).

${ }^{23}$ Zona de Expansão Urbana é a parte da zona rural fixada como limite para o desenvolvimento das zonas urbanas (PMS, 1966, Lei $\mathrm{n}^{\circ}$ 1417).
} 
Artigo 37 - As áreas destinadas ao cruzamento de rodovias e passagens de nível sobre leito de estradas de ferro, exigidas pela Prefeitura, serão consideradas como vias de comunicação.

Artigo 38 - Nos arruamentos de terrenos marginais a cursos d'água, será exigida uma faixa longitudinal no sentido do curso d'água, a saber: I - Nas margens do Rio Sorocaba, 30 m (trinta metros) de cada lado, a partir da margem do rio retificado.

(PMS, 1966, Lei $n^{\circ} 1417$ )

Notamos, assim, na leitura da lei de arruamento de 1966, a importância dada pelo município aos automóveis com a criação do viário intraurbano e com a geração de acessibilidade às rodovias estaduais. Isso contribuiu futuramente para a expansão urbana ao longo dos eixos urbanos de ligação com as rodovias e, também, às margens da ferrovia.

Dessa forma, podemos dizer que alguns dispositivos existentes nas leis municipais induziram o crescimento da mancha urbana de Sorocaba. Porém, ao mesmo tempo, outros dispositivos tentavam controlar o espraiamento da mancha urbana, uma vez que procuravam adensar a ocupação urbana no entorno da área infraestruturada. De acordo com Zimmermann, havia

(...) um dispositivo legal do município que obrigava aos novos loteamentos situarem-se num raio de 500 metros no máximo das áreas infraestruturadas. Tal dispositivo é claramente cercador de especulação geograficamente aberta e reforçador da rentabilidade dos capitais aplicados em infraestrutura. (Zimmermann, 1992, p. 169)

Resultado disso foi a criação de um sistema viário em anéis, radioconcêntrico, como podemos ver no croqui apresentado na sequência, que limitava a área de expansão urbana de Sorocaba. A construção do $1^{\circ}$ anel viário, proposto pelo Plano Diretor de 1966 em torno da área central,

(...) contribui muito para aliviar a área central do tráfego de passagem, porém como os dois outros anéis propostos $\left(2^{\circ}\right.$ e $\left.3^{\circ}\right)$ não se mostraram totalmente viáveis (na maioria por problemas topográficos) é necessária a adoção de novas propostas de ligações entre as diferentes regiões da cidade [com a criação de vias arteriais e coletoras]. O centro principal ficou envolvido pelo $1^{\circ}$ Anel Viário, porém várias vias acabaram se transformando em corredores comerciais, fazendo com que as atividades comerciais se expandissem para além dos limites da área central. (Plano Diretor PMS, 1990, ps. 39, 40) 


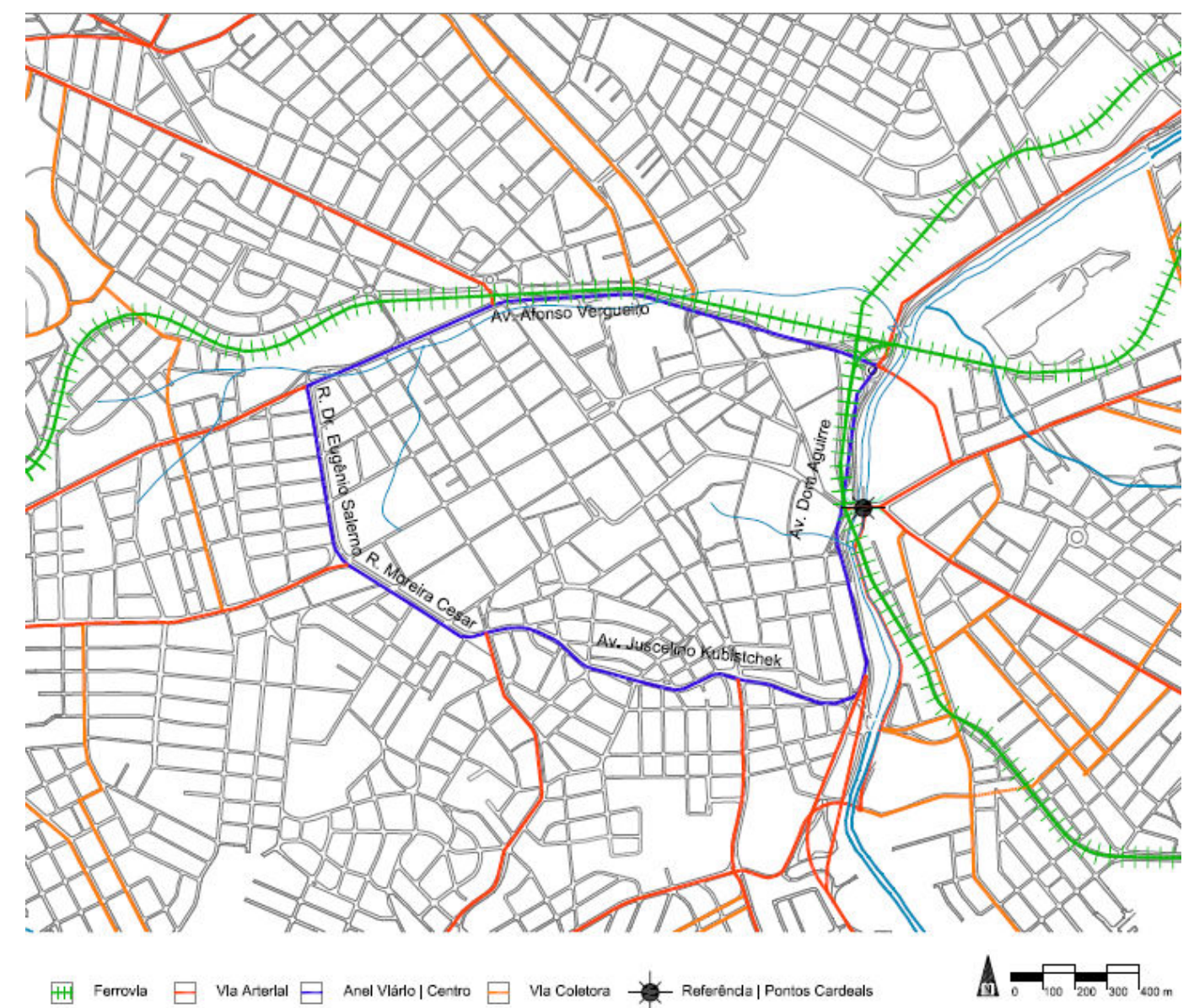

Croqui 34. Croqui do anel viário implantado pelo PD de 1966 em Sorocaba.

Baseado em: Prefeitura Municipal de Sorocaba. Crédito: Andressa Celli.

Sorocaba, favorecida pela localização e acessibilidade à rede de transportes regionais, principalmente após a década de 1960 com a construção da Rodovia Castelo Branco, de acordo com Zimmermann (1992), absorveu grande parte da produção industrial do Estado de São Paulo. Com isso, impulsionou significativamente o crescimento de outras regiões da cidade, mais distantes do centro de Sorocaba. Os bairros do Éden e Aparecidinha são exemplos disso. A rodovia Raposo Tavares, por sua vez, estimulou o crescimento de Votorantim.

O caso de Votorantim, no entanto, merece destaque. A característica 'industrial' de Votorantim, vista no capítulo anterior, propiciou que a sua mancha urbana se desenvolvesse quase que exclusivamente em função da dinâmica industrial ali instalada, desde os primórdios da fábrica de tecidos no final do século XIX. 
Votorantim merece atenção especial pois, embora sempre ligada ao centro de Sorocaba, desenvolveu ao longo dos anos seu parque industrial de forma bastante intensa. Esse município, de acordo com Zimmermann (1992), deixou de ser distrito de Sorocaba e passou a ser um município independente em 1965, transformando "em município uma parte integrante da malha viária urbana de Sorocaba".

Essa separação, meramente 'administrativa', "seccionou a mesma malha viária, cuja expansão já apresentava sinais de superação das barreiras físicas e rodoviárias" (Zimmermann, 1992, p. 161) e que, mais tarde, apresentaria um inevitável processo de conurbação ${ }^{24}$ com a região sul do município de Sorocaba.

De acordo com Meira (2006), em função da dinâmica industrial em que Sorocaba se encontrava, o município procurou organizar o crescimento industrial na cidade e, com o auxílio de instrumentos do seu plano diretor criou, a partir dos anos de 1970, zonas industriais no município, próximas aos acessos às rodovias.

Em termos territoriais, o município privilegiou, desde seus primeiros planos e zoneamentos a existência de zonas restritas ao uso industrial, ou seja, criou uma reserva de terra para esse uso. Em 1970 foram aprovados os Distritos Industriais, destinados exclusivamente à implantação de indústrias e outros investimentos afins que lhes dessem suporte, com uma área inicial de 25 bilhões de $\mathrm{m}^{2}$. (Santoro e Cymbalista e Nakahima, 2005, p. 4)

Assim, em $1971^{25}$, um novo plano foi aprovado, o Plano Diretor de Desenvolvimento Integrado (Lei $n^{\circ} 1672$ ). Tratava-se

(...) de um plano principalmente de diretrizes: para compatibilizar o adensamento e disponibilidade de serviços públicos e equipamentos sociais; estímulo à concentração de atividades

\footnotetext{
24 "O processo de conurbação ocorre quando uma cidade passa a absorver núcleos urbanos localizados à sua volta, pertençam eles ou não a outros municípios. Uma cidade absorve outra quando passa a desenvolver com ela 'intensa vinculação socioeconômica'. Esse processo envolve uma série de transformações tanto no núcleo urbano absorvido como no que absorve" (Villaça, 2001, p. 51).

${ }^{25}$ Lei $n^{\circ} 1672$, de 1971, que dispõe sobre a instituição do plano diretor de desenvolvimento integrado do município de Sorocaba para ordenar e disciplinar o seu desenvolvimento físico, econômico, social e administrativo de forma a propiciar o bem-estar da comunidade (Prefeitura Municipal de Sorocaba).
} 
comerciais, de prestação, estímulos às atividades industriais, propostas de acessibilidade, melhoria do acesso ferroviário e rodoviário. Do ponto de vista dos instrumentos urbanísticos, o Plano reitera a validade das leis urbanísticas até então. (Santoro e Cymbalista e Nakahima, 2005, p. 7)

Na sequência, foram aprovadas leis que alteravam partes do PDDI de 1971. Em $1976^{26}$ (Lei $n^{\circ} 1882$ ), o município reduziu os índices urbanísticos da ZR1 (zona residencial 1) e redimensionou os lotes urbanos. Em $1978^{27}$ (Lei $n^{\circ} 1962$ ) o município inovou ao incorporar a ZI (zona industrial) ao perímetro urbano, condicionando, assim, novos limites à área urbana da cidade. Dessa forma, a Zona industrial foi se reconfigurando

(...) em virtude de várias alterações de zoneamento feitas em um processo aleatório, visando principalmente à abertura de loteamentos residenciais que disputam [espaço] com as indústrias. (Santoro e Cymbalista e Nakahima, 2005, ps. 4, 5)

Esse fato foi corroborado com a instituição da Lei $n^{\circ} 1985^{28}$ no mesmo ano, responsável por transformar a ZIU (zona industrial urbana) - constituída pelos bairros do Éden, Aparecidinha e Jardim Saira - em ZRM (zona residencial de média densidade). Essa lei legitimou e orientou a ocupação dessa área, antes restrita às indústrias, por residências de classe média e baixa renda. Em relação

(...) ao uso de comércio e serviços, a legislação e as propostas de legislação já mostravam, desde a década de 60, um claro incentivo para esse uso ao longo dos corredores de tráfego de maior e média intensidade; além da concentração [da ocupação urbana] na área central. (Santoro e Cymbalista e Nakahima, 2005, ps. 4, 5)

Foi assim que, a partir de 1970, houve um grande incentivo à ocupação e expansão urbanas de Sorocaba. O crescimento de ambas foi influenciado por um

\footnotetext{
${ }^{26}$ Lei $\mathrm{n}^{\circ}$ 1882, de 1976, sobre a alteração no PDDI e a redução dos índices urbanísticos da ZR1 (Prefeitura Municipal de Sorocaba).

${ }^{27}$ Lei $n^{\circ} 1962$, de 1978 , sobre a alteração no PDDI e a incorporação da ZI ao perímetro urbano. (Prefeitura Municipal de Sorocaba).

28 Lei n ${ }^{\circ} 1985$, de 1978, sobre a alteração do PDDI e a transformação da ZIU em ZRM (Prefeitura Municipal de Sorocaba).
} 
investimento público direcionado para a constituição de um sistema viário intraurbano voltado à alimentação de uma importante rede regional de transportes.

Dessa forma, notamos que as características da ocupação e expansão urbanas, no que concerne à relação existente entre a densidade da ocupação urbana e o espraiamento da mesma, proporcionado pela expansão urbana, diferem um pouco no período pré e pós 70.

A ocupação recente, ao contrário da anterior, possui (...) baixa densidade populacional e ausência de equipamentos comerciais e de serviços de atendimento à população local.

A mancha urbana pós-70 caracteriza-se por concentrar nos corredores radiais de tráfego os equipamentos comerciais e de serviços, por vazios dentro de sua malha viária e parcelamentos urbanos de solo completamente desligados da área infraestruturada.

Os corredores radiais de tráfego que ligam a região central às regiões oeste e noroeste da cidade concentraram significativa parcela das unidades médias e pequenas produtoras de bens de consumo não duráveis (com destaque para as confecções), os maiores conjuntos habitacionais do município e os maiores núcleos de favelados. (Zimmermann, 1992, p. 172)

Assim, no período pré 70, a maior parte de comércio, serviços e residências encontrava-se na região central de Sorocaba. As novas áreas de ocupação, proporcionadas pelo sistema viário implantado, apresentavam densidade baixa, ainda muito incipientes. Já as

(...) fronteiras da ocupação urbana pós-70 seguiram ao sul com a expansão do município de Votorantim, ao sudoeste em direção à rodovia Raposo Tavares e a noroeste (...) Em que pese não ter havido no período a dominação nítida de um rumo para a ocupação urbana, a expansão das regiões do Além-Linha e do Além-Ponte destacam-se pelo acréscimo relativo do solo parcelado. (Zimmermann, 1992, ps. 170)

Com isso, foi modificado mais uma vez o perímetro urbano da cidade, agora pela Lei $\mathrm{n}^{\circ} 2026$ em $1979^{29}$.

Sendo assim, a acessibilidade dessa cidade à ferrovia e, mais tarde, à malha rodoviária estadual que se formava a fim de atender a interiorização da indústria, foi

\footnotetext{
${ }^{29}$ Lei n 2026, de 1979, sobre a alteração do perímetro urbano (Prefeitura Municipal de Sorocaba).
} 
fundamental para que Sorocaba se tornasse uma das sedes do interior paulista a abrigar a industrialização. Afinal,

[a] simples observação indica que as grandes zonas industriais se desenvolveram ao longo das grandes vias regionais, inicialmente ao longo das ferrovias, depois também ao longo de rodovias. (...) [E que] as principais zonas industriais se desenvolveram junto às vias regionais mais movimentadas, ou seja, aquelas que estabeleciam as ligações regionais mais importantes. (Villaça, 2001, p. 135)

De acordo com dados da Prefeitura Municipal de Sorocaba, a concentração industrial da cidade

(...) deve-se muito à construção da Rodovia Castelo Branco nos anos [de 1967], que proporcionou a acessibilidade necessária à área metropolitana, região que paralelamente vem apresentando um processo espontâneo de desconcentração industrial.

Além disso, outros fatores que também podem ser citados são: o crescimento econômico verificado no país na década de [19] 70, a [elaboração] do Plano de desenvolvimento Industrial de Sorocaba no final da década anterior, a facilidade de ligação rodoviária e ferroviária com todo o Estado e os incentivos fiscais dados por Administrações Municipais anteriores. (Plano Diretor PMS, 1990, p. 36)

A constituição da malha rodoviária estadual, que atendia a região e o município de Sorocaba, especificamente as Rodovias Raposo Tavares e a Castelo Branco, criou e fortaleceu acessos intraurbanos na cidade de Sorocaba na direção dos caminhos estabelecidos ou fortalecidos pelas rodovias e cidades vizinhas. Verificamos isso ao lermos o trecho abaixo e também nos croquis apresentados a seguir.

A inauguração da Rodovia Raposo Tavares SP-270 (1954) e, posteriormente, da Rodovia Castelo Branco SP-280 (1967) foram elementos indutores e consolidadores de um novo momento para sua economia, a indústria se concentrou na produção de bens de consumo. $O$ território também passou por uma nova estruturação, as indústrias passam a ladear as rodovias, privilegiando a acessibilidade rodoviária e desligando-se do eixo ferroviário. (Santoro e Cymbalista e Nakahima, 2005, p. 2) 
35. Croqui Viário e Ocupação Urbana de 1981 
36. Croqui Regional e Urbano de 1981 
Com a constituição da malha rodoviária e também dos novos acessos intraurbanos criados na direção dos caminhos estabelecidos pelas rodovias, ocorreu um notável crescimento urbano. Mais do que isso, o desenvolvimento econômico proporcionou um repentino aumento da população urbana de Sorocaba nas direções norte, noroeste, oeste e sul.

Esse fato culminou em um considerável crescimento da ocupação urbana depois de 1980, pois já a partir de 1970 "a desconcentração industrial da cidade de São Paulo impulsionou a consolidação de Sorocaba como polo industrial do Estado nesta nova fase, acompanhado de um grande fluxo migratório e grande ampliação da área urbanizada" (Santoro e Cymbalista e Nakahima, 2005, p. 2).

De acordo com Zimmermann, nos anos 80,

(...) o crescimento seguiu espalhando-se de maneira semelhante à da década anterior, aprofundando as modificações do perímetro recém-operadas. Acelerou-se a ocupação na direção dos espaços abertos entre 1974-80, preenchendo parte dos espaços vazios deixados pela expansão precedente. Mas, com destaque nos anos 80, a 'lei dos 500' foi generalizadamente descumprida, e Sorocaba apresenta atualmente [1990] o mesmo processo de criação de espaços vazios intersticiais comuns às urbanizações mais recentes. Cabe ainda sublinhar que na expansão dos anos 80 o corredor de ligação Sorocaba-Votorantim foi expandido e confundem-se perfeitamente as malhas urbanas dos dois municípios. A malha urbana seguiu, nesse aspecto, a tendência delineada à época do desmembramento de Votorantim e sua elevação à categoria de município.

Por último, cabe destacar a expansão para o leste, notadamente em direção à rodovia Ermírio de Moraes (ligação Sorocaba - Castelo Branco), região que abriga os distritos industriais do Éden, Aparecidinha e Cajuru e as áreas urbanas circundadas pelos eixos rodoviários (rodovias Ermírio de Moraes, Raposo Tavares e Castelo Branco). (Zimmermann, 1992, ps. 170, 171)

Assim, na direção das rodovias, notamos, ao analisar os croquis de 1981, o crescimento da ocupação urbana, estimulada não só pela acessibilidade do sistema viário, mas também pela localização das novas indústrias nas proximidades desses percursos.

As indústrias antes localizadas mais próximas ao centro de Sorocaba, nas proximidades da estação central ferroviária e também do leito do trem, no período 
após a década de 1970, mudam de lugar, passam a localizar-se próximas aos acessos às rodovias e não mais no entorno da ferrovia. Podemos afirmar isso ao compararmos os croquis de 1939 com os de 1981.

Notamos ainda, ao analisar os croquis de 1981, que a ocupação gerada no entorno dessas indústrias caracteriza-se por loteamentos urbanos de baixa renda. São as novas vilas operárias de Sorocaba que se constituem nas proximidades das novas zonas industriais, localizadas nos subúrbios de Sorocaba.

Apesar disso, outras indústrias, de pequeno porte, deslocaram-se para o oeste do município. Notamos nos croquis de 1981 a localização de conjuntos habitacionais populares, principalmente ao norte, como o Parque São Bento, Jardim Santa Marina e Jardim São Guilherme. Os novos loteamentos populares situaram-se,

(...) preferencialmente na zona oeste, nas cercanias dos núcleos de favelas e das pequenas e médias indústrias (confecções notadamente) em sua maioria constituídas por capitais Sorocabanos. O privilegiamento do oeste, quando já se havia definido o norte com área para recepção das novas indústrias, provavelmente reflete interferência do capital proprietário de terras. É na região oeste que, segundo análise visual do sistema viário, se localizam os maiores vazios urbanos da parte interior da mancha urbana. É na região norte, na área do último conjunto habitacional construído, que o parcelamento do solo e consequente expansão da mancha urbana foram precedidos pela construção das moradias populares e do novo Paço Municipal, às margens da ligação Sorocaba - Castelo Branco. (...) Em resumo, a expansão recente evidencia também em Sorocaba a periferização da pobreza e a criação de vazios urbanos em áreas concentradas. (Zimmermann, 1992, p. 173)

Em $1990^{30}$, o município estabeleceu novos parâmetros reguladores do crescimento da cidade. Elaborou-se, então, o Novo Plano Diretor do Município de Sorocaba, que foi aprovado pela Câmara em 1991.

Já havia se passado mais de vinte anos sem uma única revisão do plano diretor precedente (1971). Nesse período, de acordo com o Plano Diretor de 1990, permitiu-se que

\footnotetext{
301990 - Novo Plano Diretor, Zoneamento e Plano Viário do Município de Sorocaba (Prefeitura Municipal de Sorocaba).
} 
(...) novos espaços fossem ocupados sem macro-diretrizes para o sistema viário. A cidade sofreu uma grande expansão para além da área abrangida pelo Plano Diretor de 1964, sem a previsão de áreas para novas vias de ligação dessas regiões entre si e com a região central. (Plano Diretor PMS, 1990, p. 78)

O plano de 1990 alterou perímetro urbano e modificou o zoneamento da cidade. Com o intuito de estimular o crescimento urbano, a lei corroborou com a dinâmica urbana. A essa altura, a expansão urbana ao longo das vias intraurbanas de acesso às zonas industriais e às rodovias já estava constituída. (Ver croquis de 1994) A conurbação de Sorocaba com o município de Votorantim é exemplo desse processo. 
37. Croqui Viário e Ocupação Urbana de 1994 
38. Croqui Regional e Urbano de 1994 
Vemos mais uma vez, nos croquis de 1994, a configuração da ocupação urbana ao longo dos eixos viários de ligação com as rodovias. Ao mesmo tempo, há significativo crescimento na direção oeste.

Mais tarde, em $1999^{31}$, foi necessário rever mais uma vez o planejamento de Sorocaba, quando se deu início à preparação de outro plano diretor. Inicialmente, com a ajuda de uma equipe técnica especializada no desenvolvimento de planos diretores, o município elaborou um diagnóstico da estrutura urbana de Sorocaba. Com isso, a prefeitura municipal e a empresa Ambiente Urbano Planejamento e Projetos S/C Ltda. desenvolveram o Relatório de Caracterização Urbana (da estrutura urbana de Sorocaba) de 1999. Esse relatório foi construído

(...) com informações que já existiam em Sorocaba, elaboradas continuamente desde a década de 80, a partir dos diversos levantamentos construídos nas tentativas de planos elaborados com outras consultorias. Já havia inclusive uma vasta cartografia digitalizada. Nessa etapa de construção do diagnóstico, aconteceram reuniões técnicas e não aconteceram reuniões públicas com a população. (Santoro e Cymbalista e Nakahima, 2005, ps. 6, 7)

Com base nesse estudo de 1999, podemos dizer que o município estabeleceu, desde a década de 1970, a criação de zonas industriais e loteamentos urbanos próximos a essas zonas. Como vemos nos croquis de 2000, essas zonas industriais e os loteamentos urbanos associados a elas, desenvolveram-se preferencialmente na direção norte do município.

\footnotetext{
${ }^{31} 1999$ - Relatório de Caracterização do Município de Sorocaba; Lei n 5878 , de 1999; suprime os parágrafos e dá nova redação ao artigo 49 da lei $n^{\circ} 1.417$ de 30 de junho de 1966, que aprovou o código de arruamento e loteamento (Prefeitura Municipal de Sorocaba).
} 
39. Croqui Viário e Ocupação Urbana de 2000 
40. Croqui Regional e Urbano de 2000 
Segundo Meira (2006), concomitante à implantação dessas zonas industriais, havia incentivos fiscais dados pela prefeitura para a instalação de indústrias nesses locais. Houve, assim, políticas municipais de incentivos fiscais para atrair essas indústrias, "como os do período de 1991 a 2001, que incentivavam empresas de tecnologia de ponta (que atendessem às exigências legais da Lei Municipal $\mathrm{n}^{\circ}$ 3.691/91 e Lei Municipal n 4.256/94)" (Santoro e Cymbalista e Nakahima, 2005, p. 4).

Essa determinação teve o propósito de estabelecer uma maior concentração de capitais e de mão de obra especializada, com o foco de estimular o crescimento das rendas médias do município e, com isso, o poder aquisitivo da população (Plano Diretor PMS, 1990, p. 37).

Ao compararmos os croquis de 1994 e de 2000, notamos que o crescimento da mancha urbana ao norte e oeste é bastante significativo. A expansão urbana se delineia ao longo e nas proximidades dos eixos de ligação arteriais urbanos, que se conectam com a cidade de Porto Feliz e a Rodovia Castelo Branco.

O crescimento a leste e a nordeste não apresenta, da mesma forma, significativo crescimento da mancha urbana. Porém, é preciso salientar o surgimento de condomínios fechados nessa direção. O Jardim Granja Olga e o Jardim Village Saint Claire são dois exemplos de condomínios fechados voltados à classe média e alta (Ver croquis de 1994 e de 2000).

Incrustados em uma antiga área rural e cercados por muros, cada um situa-se em margens opostas à linha férrea. O acesso a esses condomínios é feito por meio de vias artérias, de ligação com a Rodovia Castelo Branco. Ao redor desses condomínios, encontram-se pequenas indústrias e chácaras.

Essa nova configuração de bairro, que se apresenta na estrutura urbana de Sorocaba a partir do final do século XX, originou-se em função de um

(...) novo padrão de mobilidade espacial decorrente da difusão no uso do automóvel, com as novas frentes de acessibilidade que ele criou e com o novo espaço urbano que foi para ele produzido e para as camadas de mais alta renda. Essa nova mobilidade territorial, juntamente com o empenho do capital imobiliário em tornar obsoletos os centros existentes e promover novos centros e novas frentes imobiliárias, fez com que um novo padrão de deslocamento se estabelecesse em nossas metrópoles. (Villaça, 2001, p. 281) 
Posteriormente, com base nesse relatório de 1999, instituiu-se o plano diretor de desenvolvimento físico territorial do município de Sorocaba em $2004^{32}$ (Lei $\mathrm{n}^{\circ}$ 7122). Reiterou-se, portanto, a ênfase dada pelo município ao desenvolvimento industrial especializado.

A inovação mais significativa do plano de 2004, em relação aos planos anteriores, foi a compatibilização de sua redação à regulamentação federal instituída em 2001 pelo Estatuto da Cidade (Lei $n^{\circ}$ 10257). De acordo com Olívio Dutra,

[a]s inovações contidas no Estatuto situam-se em três campos: um conjunto de instrumentos de natureza urbanística, voltados para induzir - mais do que normatizar - as formas de uso e ocupação do solo; uma concepção de gestão democrática das cidades que incorpora a ideia de participação direta do cidadão(ã) nos processos decisórios sobre seus destinos; e a ampliação das possibilidades de regularização das posses urbanas, até hoje situadas na ambígua fronteira entre o legal e o ilegal. (Estatuto da Cidade, 2005)

Em $2007^{33}$, o plano diretor de 2004 foi revisado pela Lei $n^{\circ} 8181$, instituindose, com isso, um novo plano diretor para a cidade de Sorocaba. Esse é o plano diretor atual, em vigor nesse ano de 2010.

Em comparação com o plano diretor de 2004, o plano atual apresenta maior apuro técnico, no que concerne ao detalhamento apresentado em alguns dos artigos do plano. Notamos, por exemplo, uma descrição mais detalhada a respeito da restrição da ocupação das áreas de zonas de conservação ambiental, constando dados como os de recuos aos cursos d'água, onde não pode haver construção e loteamentos urbanos. Verificamos isso também na regulamentação sobre os Polos Geradores de Tráfego e no próprio zoneamento, esse mais restritivo quanto aos índices de taxa de ocupação e coeficiente de aproveitamento.

\footnotetext{
32 Lei $n^{\circ}$ 7122, de 2004, (revisada pela lei $n^{\circ}$ 8181/2007), que institui o plano diretor de desenvolvimento físico territorial do município de Sorocaba e dá outras providências (Prefeitura Municipal de Sorocaba).

${ }^{33}$ Lei n 8181, de 2007, revisão da lei 7.122 de 04/6/2004 (Prefeitura Municipal de Sorocaba).
} 
Podemos dizer, enfim, que existe um ponto em comum a todos esses planos diretores: o incentivo dado pelo município ao desenvolvimento do seu parque industrial, principalmente o de tecnologia de ponta. De acordo com Meira,

[a] principal característica do planejamento urbano de Sorocaba sempre foi a correspondência do crescimento urbano aos anseios dos investimentos industriais que foram marcantes na cidade durante o século XX. (...) as prioridades desde a elaboração do Plano Diretor de desenvolvimento Integrado - PDDI de 1971 até a elaboração do atual [2004] Plano Diretor de Desenvolvimento Físico - Territorial do Município de Sorocaba (PDDFTS) foram o ordenamento do crescimento urbano com segurança para a manutenção do crescimento econômico, principalmente o industrial. A transformação do distrito de Votorantim em município na década de 1960 e a consequente perda de arrecadação das atividades industriais concentradas nessa localidade fizeram com que o Plano Diretor de Desenvolvimento Integrado de 1971 revisse a possibilidade de instalação de uma nova zona industrial em Sorocaba que não fosse tão próxima da área urbana, mas também não muito distante dela. (Meira, 2006, p. 64)

A política viária instaurada ao longo dos planos diretores orientou 0 direcionamento do crescimento urbano ao longo das vias intraurbanas que se ligavam às rodovias estaduais. Verificamos, ao mesmo tempo, que a ocupação urbana acompanhou a implantação e o fortalecimento desse viário, culminando em uma grande expansão da mancha urbana da cidade de Sorocaba (ver foto aérea de 2009). 


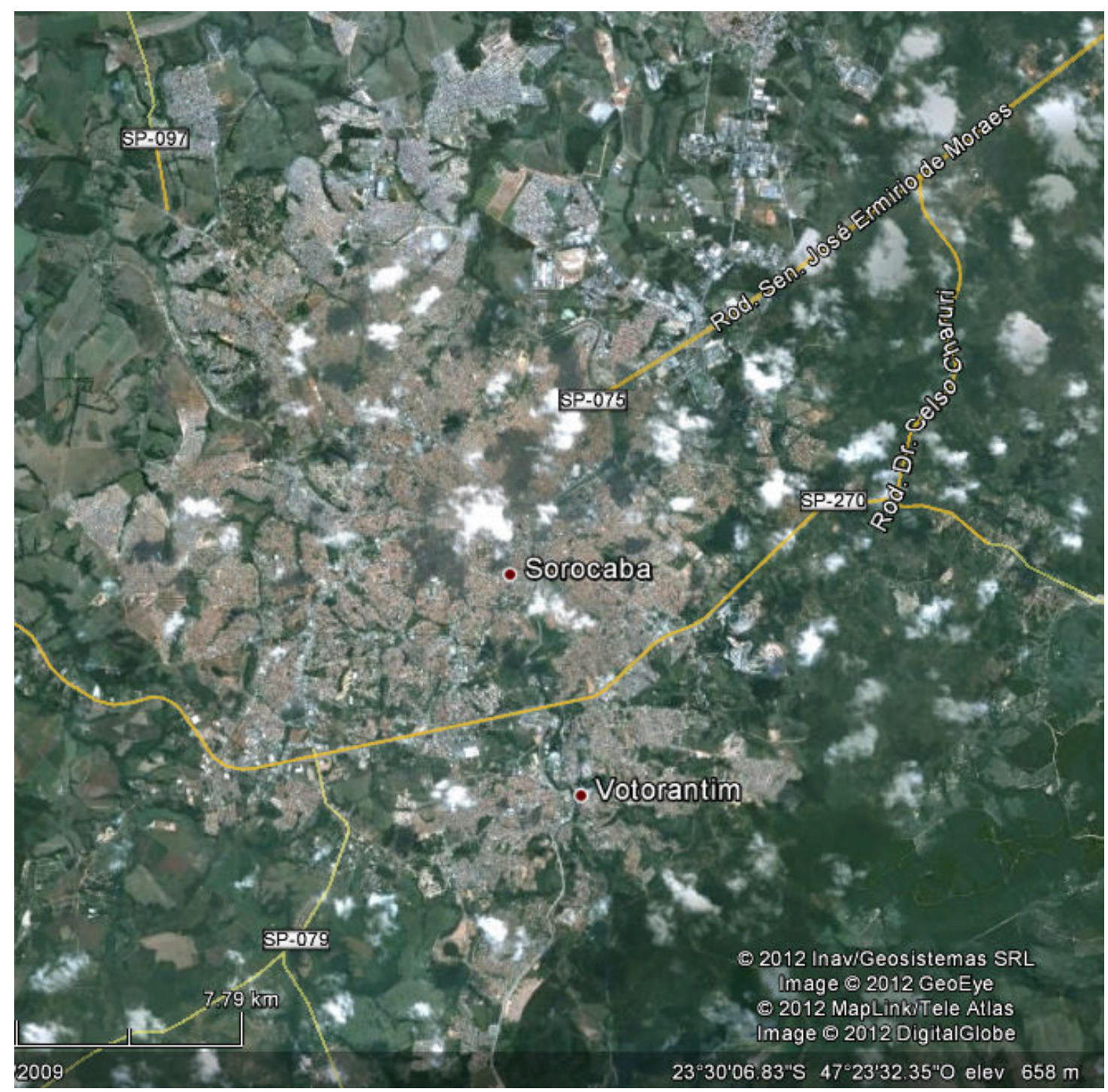

Figura 13. Foto aérea de Sorocaba em 2009.

Google Earth, Acessado em 2012.

Tal política, que, como vimos, foi mantida até hoje, resultou na criação de um grande parque industrial na periferia da cidade, desenvolvido ao longo das vias regionais de transporte. A Rodovia

(...) Raposo Tavares SP-270 (1954) e, posteriormente, [a] Rodovia Castelo Branco SP-280 (1967) foram elementos indutores e consolidadores de um novo momento para [a] economia [de Sorocaba], [cuja] indústria se concentrou na produção de bens de consumo. $O$ território também passou por uma nova estruturação, as indústrias passam a ladear as rodovias, privilegiando a acessibilidade rodoviária e desligando-se do eixo ferroviário. 
Nos anos 70, a desconcentração industrial da cidade de São Paulo impulsionou a consolidação de Sorocaba como polo industrial do Estado nesta nova fase, acompanhado de um grande fluxo migratório e grande ampliação da área urbanizada. Houve um aumento na taxa de crescimento populacional de 4,3\% entre 1970 e 1980 , maior taxa até hoje (em 200, estimou-se $2,9 \%$. O campo passou também por reestruturação produtiva no período. (Santoro e Cymbalista e Nakahima, 2005, p. 2)

Assim, vimos que as novas indústrias do período pós Raposo Tavares e Castelo Branco passaram a se instalar na periferia da cidade, ao longo desses caminhos. Ao mesmo tempo, as vilas operárias ou mesmo os loteamentos urbanos de baixa renda seguiram também esses mesmos caminhos e a se instalaram próximos às fábricas novas.

Podemos dizer, então, que a industrialização foi responsável por proporcionar um grande impulso na expansão urbana da cidade. Mesmo com a existência de barreiras físicas, como a ferrovia e o rio Sorocaba, os bairros do Além Linha e Ponte se desenvolveram significativamente.

Orientados pelo ritmo das mudanças socioeconômicas e pelos parâmetros estabelecidos pelos planos diretores municipais; o sistema viário e a ocupação urbana configuraram a Sorocaba dos dias atuais. 


\section{Considerações Finais}

Sorocaba constitui-se hoje em uma cidade paulista de médio porte desenvolvida e de grande importância no processo de produção industrial nacional. A cidade está localizada regionalmente em um ponto estratégico, não somente em termos geográficos, mas também em relação aos eixos viários e de ligação que a atendem. Essa característica de ligação está presente em Sorocaba desde o período que antecedeu a sua formação até os dias de hoje.

A característica de ligação regional existente em Sorocaba foi estabelecida primeiramente pelo ramal principal do Peabiru - caminho indígena que ligava a região sul à oeste do Brasil. Esse caminho induziu o estabelecimento de ocupações indígenas na região de Sorocaba e, mais tarde, à formação do povoado fundado por Baltazar Fernandes, em 1654. Afinal, a ligação regional estabelecida pelo Peabiru, foi utilizada também pelas bandeiras em suas expedições para o sertão paulista.

O povoado de Sorocaba estabeleceu-se na margem esquerda do rio Sorocaba em um ponto elevado do relevo. E, em 1661, o povoado foi elevado à Vila de Nossa Senhora da Ponte. Nessa data, como podemos verificar no croqui apresentado a seguir referente ao período de 1661 a 1839, a estrutura urbana de Sorocaba era formada por poucas ruas e por uma população de índios e bandeirantes. Havia também algumas construções, como Capelas e a Casa de Câmara e Cadeia. 
41. Croqui referente ao período de 1661 a 1839 
O viário existente em 1661 constituiu-se ao longo do antigo traçado do ramal principal do Peabiru, rota bandeirante, nas proximidades do entroncamento dos ramais secundários e das ramificações do Peabiru, isto é, dos caminhos regionais. $\mathrm{O}$ núcleo da vila foi formado nas imediações desses caminhos regionais, percorridos pelos bandeirantes.

Esses mesmos caminhos foram utilizados mais tarde pelos tropeiros para o transporte de mercadorias e comércio de muares, entre o sul e o oeste do Brasil, entre 1700 e 1800, o que estimulou o crescimento de Sorocaba também ao longo dos mesmos caminhos regionais de outrora.

Sorocaba foi sede da feira de muares e importante referencia do comércio instituído pelo Tropeirismo, a partir de 1733. Esse fato contribuiu para que se formasse em Sorocaba um mercado urbano e, com esse desenvolvimento socioeconômico, Sorocaba foi elevada à categoria de cidade em 1842.

Os itinerários dos tropeiros também foram responsáveis por induzir o crescimento urbano de Sorocaba. As tropas passavam por dentro da cidade para comercializar seus produtos e, com isso, estimularam a formação de novas ruas que, por sua vez, levaram à ocupação de novas áreas ao noroeste, leste e sudoeste de Sorocaba.

A partir de meados de 1800, concomitante ao comércio de muares estabeleceu-se em Sorocaba a produção de algodão e, em 1870, a cidade já era grande produtora dessa matéria-prima. A cultura do algodão foi estimulada por alguns empresários sorocabanos, os quais tinham como objetivo a exportação desse produto.

Em função disso, esses mesmos empresários construíram, posteriormente, uma ferrovia capaz de escoar a produção de algodão até o porto de Santos. Fundou-se, então, em 1875, a Estrada de Ferro sorocabana, que substituiria aos poucos o transporte regional efetuado pelos tropeiros.

Assim, a partir de 1888, verificamos que o crescimento urbano de Sorocaba foi direcionado pela implantação da ferrovia. Esse fato é corroborado pelo croqui apresentado a seguir, referente ao período de 1888 a 1925. 
42. Croqui referente ao período de 1888 a 1952 
Como vimos, a instalação da ferrovia favoreceu primeiramente a criação do viário na direção da estação central da Estrada de Ferro Sorocabana, localizada no centro de Sorocaba, em função do transporte local de mercadorias.

Posteriormente, com o desenvolvimento da cultura de algodão e de seu beneficiamento, surgiram em Sorocaba fábricas de tecido. Essas, por sua vez, instalaram-se nas imediações da estação e ao longo dos leitos ferroviários e, ao mesmo tempo, induziram a formação de ruas que ligavam essas fábricas ao viário já existente.

Desse modo, a construção das fábricas de tecidos favoreceu a formação de vilas operárias em seu entorno e, mais tarde, a formação de loteamentos além dos limites das vilas, constituindo-se assim novos bairros de Sorocaba.

A partir de meados de 1950, em função de mudanças socioeconômicas regionais, o Estado de São Paulo construiu na região de Sorocaba duas rodovias: a Raposo Tavares, em 1954, e a Castelo Branco, em 1967. As rodovias substituiriam, aos poucos, o transporte regional efetuado antes pela ferrovia.

Essas rodovias que ligavam Sorocaba a São Paulo, e também a outras cidades do interior paulista, encontravam-se próximas ao núcleo urbano de Sorocaba. As rodovias geraram transformações no sistema viário de Sorocaba, uma vez que induziram a criação de acessos urbanos nas direções das rodovias.

Podemos verificar isso ao observarmos o croqui-síntese do período de 1962 a 2000, apresentado na sequência. 
43. Croqui referente ao período de 1962 a 2000 
A estrutura urbana de Sorocaba, nesse período, desenvolveu-se na direção dessas rodovias: foi estimulada pelo município a criação de um viário urbano que ligava o centro e bairros da cidade às rodovias Raposo Tavares e Castelo Branco.

O crescimento do viário e da ocupação urbana foi influenciado pelos planos diretores municipais, instituídos a partir de 1966, os quais estabeleceram normas de arruamento e zonas industriais nas direções desses caminhos.

Assim, as novas indústrias que se estabeleceram em Sorocaba, principalmente a partir de meados de 1970, estimuladas pelo II PND, localizaram-se nas proximidades dos acessos a essas rodovias, a sudeste e nordeste.

Em consequência disso, induziram a ocupação urbana nas imediações das vias arteriais, formada por loteamentos de baixa renda e conjuntos habitacionais, estabelecidos a sudeste, nordeste e noroeste.

Por fim, podemos dizer que o sistema viário que se desenvolveu em Sorocaba tem conexões com o sistema viário regional, estabelecidas desde os tempos mais remotos. Notamos isso ao analisarmos o croqui-síntese do período de 1661 a 2000, apresentado a seguir. 
44. Croqui referente ao período de 1661 a 2000 
Sendo assim, concluímos que a evolução urbana de Sorocaba deu-se inicialmente através dos caminhos estabelecidos pelos índios, bandeirantes e tropeiros. Posteriormente, o crescimento urbano de Sorocaba foi estimulado pela construção da ferrovia Sorocabana e, mais tarde, pela ação do Estado de São Paulo na construção das rodovias Raposo Tavares e Castelo Branco, e pela ação do município, com a construção de vias arteriais de ligação com essas rodovias.

Enfim, concluímos que tais transformações da estrutura urbana de Sorocaba, no que concerne ao sistema viário e à ocupação urbana, foram estimuladas por mudanças socioeconômicas regionais estaduais e municipais.

Configurou-se, assim, a evolução urbana de Sorocaba em diferentes períodos de seu crescimento urbano, de 1661 a 2000. 


\section{Bibliografia}

BADDINI, Cássia Maria. Sorocaba no Império: comércio de animais e desenvolvimento urbano. São Paulo: Annablume/Fapesp, 2002.

BOND, Rosana. O Caminho do Peabiru. Fundação Campo Mourão, 1996. Disponível em: $\quad$ http://portotibirica.blogspot.com/2007/11/peabiru-mais-antiga-estradabrasileira.html. Acesso em: 20.03.2011 às 14h50min.

BRASIL. Estatuto da Cidade: guia para implementação pelos municípios e cidadãos: Lei n. 10.257, de 10 de julho de 2001, que estabelece diretrizes gerais da política urbana. $3^{\text {a }}$ edição. Brasília: Câmara dos Deputados, Ministério das Cidades, Coordenação de Publicações, 2005.

BUGANZA, Cintia Peres. Estudo da situação pré-metropolitana de Sorocaba: características e perspectivas. Dissertação de Mestrado. Universidade de São Paulo, São Paulo, 2010.

CAMPOS FILHO, Cândido Malta. Cidades Brasileiras: seu controle ou o caos: o que os cidadãos devem fazer para a humanização das cidades no Brasil. São Paulo: Studio Nobel, $1992,2^{\mathrm{a}}$ ed.

CASTELLS, Manuel. A Questão Urbana. São Paulo: Paz e Terra, 2006 [1975], $3^{\mathrm{a}}$ ed.

CANO, Wilson (coord.). A Interiorização do Desenvolvimento Econômico no Estado de São Paulo (1920 - 1980). São Paulo: Fundação SEADE, v. 1, nº 01, 1988 (Coleção Economia Paulista).

- A Industrialização do Capitalismo Retardatário no Brasil (1880-1980). In Cenários e Diagnósticos, A Economia no Brasil e no Mundo. Governo do Estado de São Paulo, Secretaria de Planejamento e Gestão e Fundação SEADE, v. 1, 1992 (Coleção São Paulo no Limiar do Século XXI). 
FRIOLI, Adolfo. Sorocaba: registros históricos e iconográficos. São Paulo: Laserprint, 2003.

GASPAR, Antonio Francisco. Histórico do Início, Fundação, Construção e Inauguração da Estrada de Ferro Sorocabana - 1870 a 1875. São Paulo: Eugenio Cupolo, 1930.

Mapa de Demandas da URGHI CBH-SMT. Fonte: IPT / Comitê das Bacias Hidrográficas do Rio Sorocaba e Médio Tietê. Disponível em: <http://www.rededasaguas.org.br/comite/MapaDeDemandas.jpg>. Acesso em: 27.03.2011 às $11 \mathrm{~h} 30 \mathrm{~min}$.

Mapas de Sorocaba. Prefeitura Municipal de Sorocaba, Secretaria de Edificações e Urbanismo, Divisão de Planejamento Físico e Territorial.

MARTINS, José de Souza. O cativeiro da terra. $9^{\circ}$ ed. revista e ampliada. São Paulo: Contexto, 2010.

MARX, Murillo. Cidade Brasileira. São Paulo: Melhoramentos/Edusp, 1980.

MEIRA, Sandro Ivo de. Planejamento e gestão urbanos em Sorocaba-SP: análise das políticas públicas de habitação popular. RA'E GA, n. 12. Curitiba: Editora UFPR, 2006, p. 59-72.

MONBEIG, Pierre. O Brasil. Tradução e coordenação editorial de Antonio Christofoletti; revisão de Sueli Bastos.. São Paulo: DIFEL, 1985, 6ª ed. - Pioneiros e Fazendeiros de São Paulo. Tradução de Ary França e Raul de Andrade e Silva. Editora Hucitec e Editora Pólis. São Paulo: 1984.

Planos Diretores Municipais de Sorocaba. Prefeitura Municipal de Sorocaba, Secretaria de Edificações e Urbanismo, Divisão de Planejamento Físico e Territorial. Sorocaba: 1990. 
PRADO JR., Caio. História Econômica do Brasil. Editora Brasilense. São Paulo, Editora Brasiliense, 1956, $4^{\mathrm{a}}$ ed.

PESSOA, Laura Cristina Ribeiro. O Impacto do sistema viário no processo de formação do espaço paulista de 1700 a 1980: o Vale do Paraíba Paulista. Tese de Doutorado. Universidade de São Paulo, São Paulo, 2003.

PRESTES, Lucinda Ferreira. Sorocaba, o tempo e o espaço séculos XVIII-XX. Tese de Doutorado. Universidade de São Paulo, São Paulo, 2001.

REIS FILHO, Nestor Goulart. Evolução Urbana do Brasil. Biblioteca Pioneira, São Paulo, 1968.

. Dois séculos de projetos no Estado de São Paulo: grandes obras e urbanização; colaboradora Mônica Silveira Brito. São Paulo: Editora da Universidade de São Paulo/Imprensa Oficial, 2010.

Relatório de Caracterização. Prefeitura Municipal de Sorocaba, Secretaria de Edificações e Urbanismo, Divisão de Planejamento Físico e Territorial. Sorocaba: 1999.

ROCHA FILHO, Gustavo Neves da. O município e a política urbana no Brasil. Tese de Doutorado. Universidade de São Paulo, São Paulo, 1986.

ROSS, Jurandyr Luciano Sanches. Relevo Brasileiro: uma nova proposta de classificação. Revista do Departamento de Geografia da USP. São Paulo, v. 04, 1985, p. 25-39.

SANTORO, Paula Freire; CYMBALISTA, Renato; NAKAHIMA, Rosemeire. Plano Diretor de Sorocaba: um olhar sobre os autores e a auto-aplicabilidade dos investimentos urbanísticos. São Paulo: Instituto Polis, 2005.

SANTOS, Elina O. A industrialização de Sorocaba: bases geográficas. São Paulo: Humanitas FFLCH/USP, 1999 [1951]. 
IGC,2007.Em:http://www.google.com.br/imgres?q=regiao+administrativa+de+soroc aba. Acessado em 25.02.2012 às 20h10min.

SETUBAL, Maria Alice (coord.). Coleção Terra Paulista: histórias, arte, costumes. São Paulo: Centro de Estudos e Pesquisas em Educação, Cultura e Ação Comunitária/ CENPEC, Imprensa Oficial do Estado de São Paulo, 2004, 3v.

SILVA, Paulo Celso da. Do Novelo de Linha a Manchester Paulista - fábrica têxtil e cotidiano no início do século XX em Sorocaba. Dissertação de Mestrado. Universidade de São Paulo, São Paulo, 1995.

SIMIELLI, Maria Elena. Geoatlas. São Paulo: Ática, 1997, $22^{\text {a }}$ ed.

SINGER, Paul. Desenvolvimento econômico e evolução urbana - análise da evolução econômica de São Paulo, Blumenau, Porto Alegre, Belo Horizonte, Recife. (1968) In: SZMRECSÁNYI, Tamás. (org.) História Econômica da cidade de São Paulo. São Paulo: Globo, 2004.

Sorocaba - Uma História ilustrada 350 anos. Jornal Cruzeiro do Sul. Sorocaba: Fundação Ubaldino do Amaral, 2004.

STRAFORINI, Rafael. No caminho das tropas. Sorocaba, SP: TCM, 2001.

TEIXEIRA, Aloísio. Vinte Anos de Política Econômica - Evolução e desempenho da economia brasileira de 1970 a 1989. In Cenários e Diagnósticos, A Economia no Brasil e no Mundo. Governo do Estado de São Paulo, Secretaria de Planejamento e Gestão e Fundação SEADE, v. 1, 1992 (Coleção São Paulo no Limiar do Século XXI).

VILLAÇA, Flávio. Espaço intra-urbano no Brasil. São Paulo: Studio Nobel/Fapesp, 2001.

ZIMMERMANN, Gustavo. A Região Administrativa de Sorocaba. In Cenários e Diagnósticos, A Economia no Brasil e no Mundo. Governo do Estado de São Paulo, Secretaria de Planejamento e Gestão e Fundação SEADE, v. 8, 1992 (Coleção São Paulo no Limiar do Século XXI). 

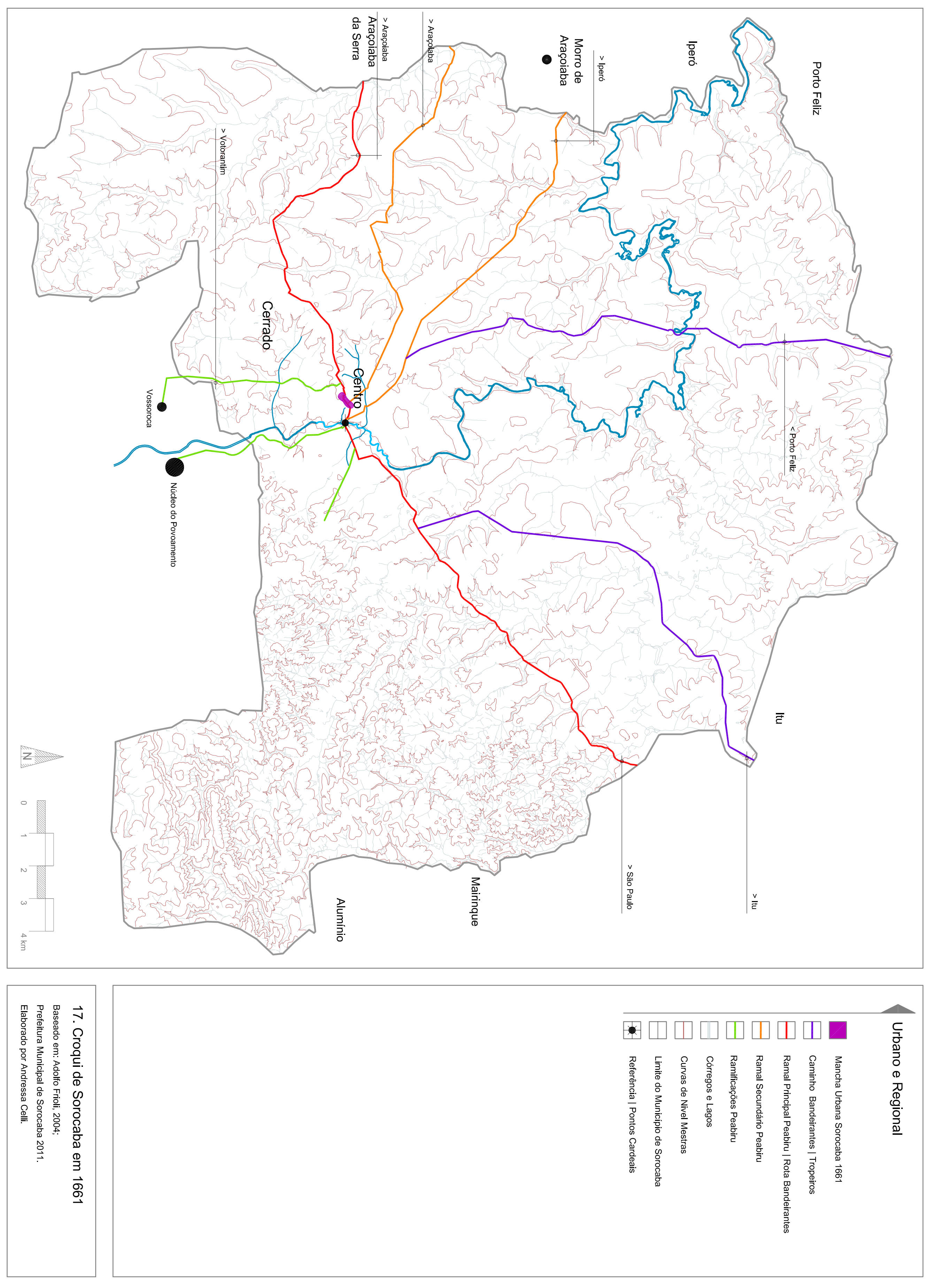


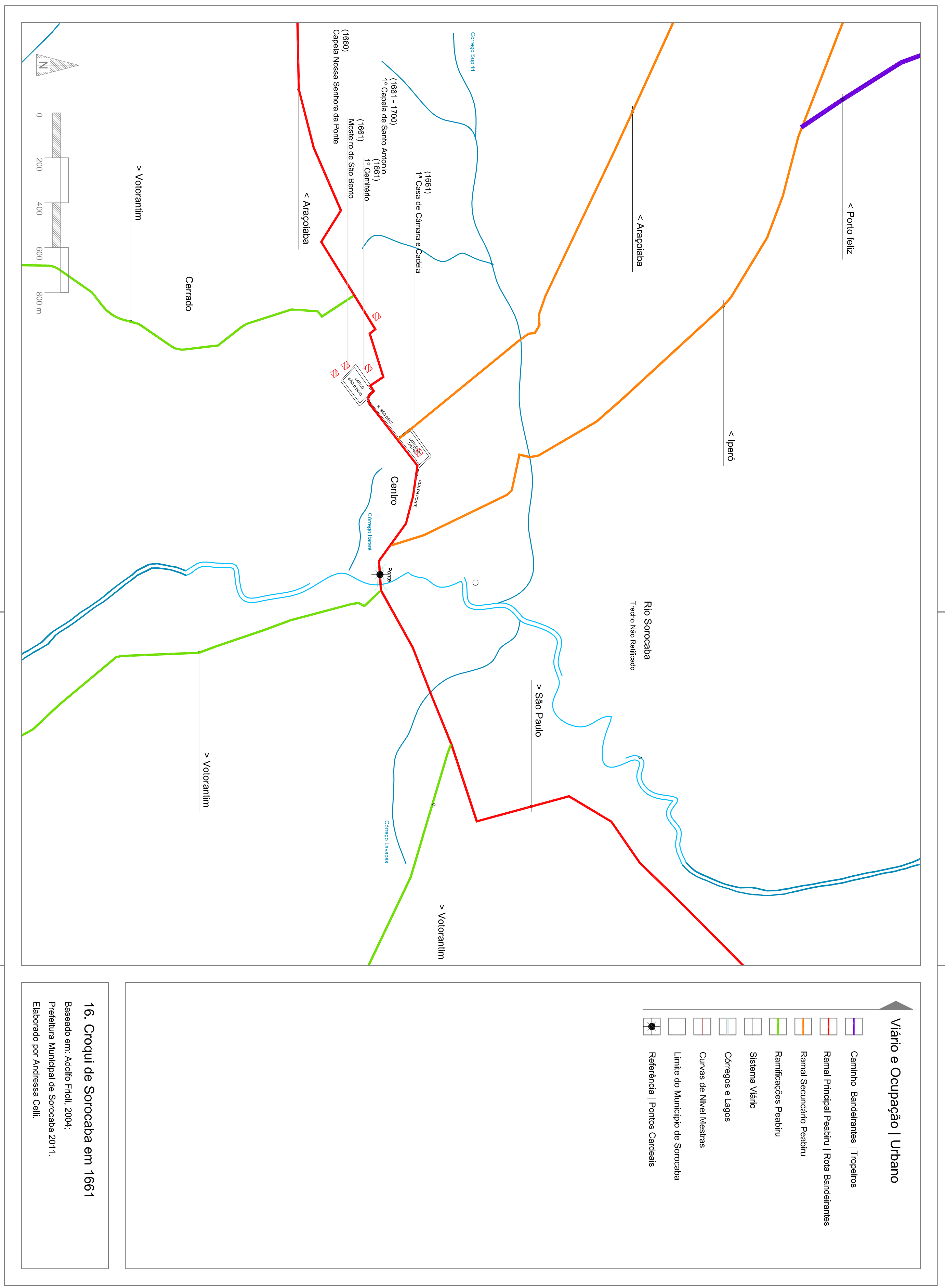



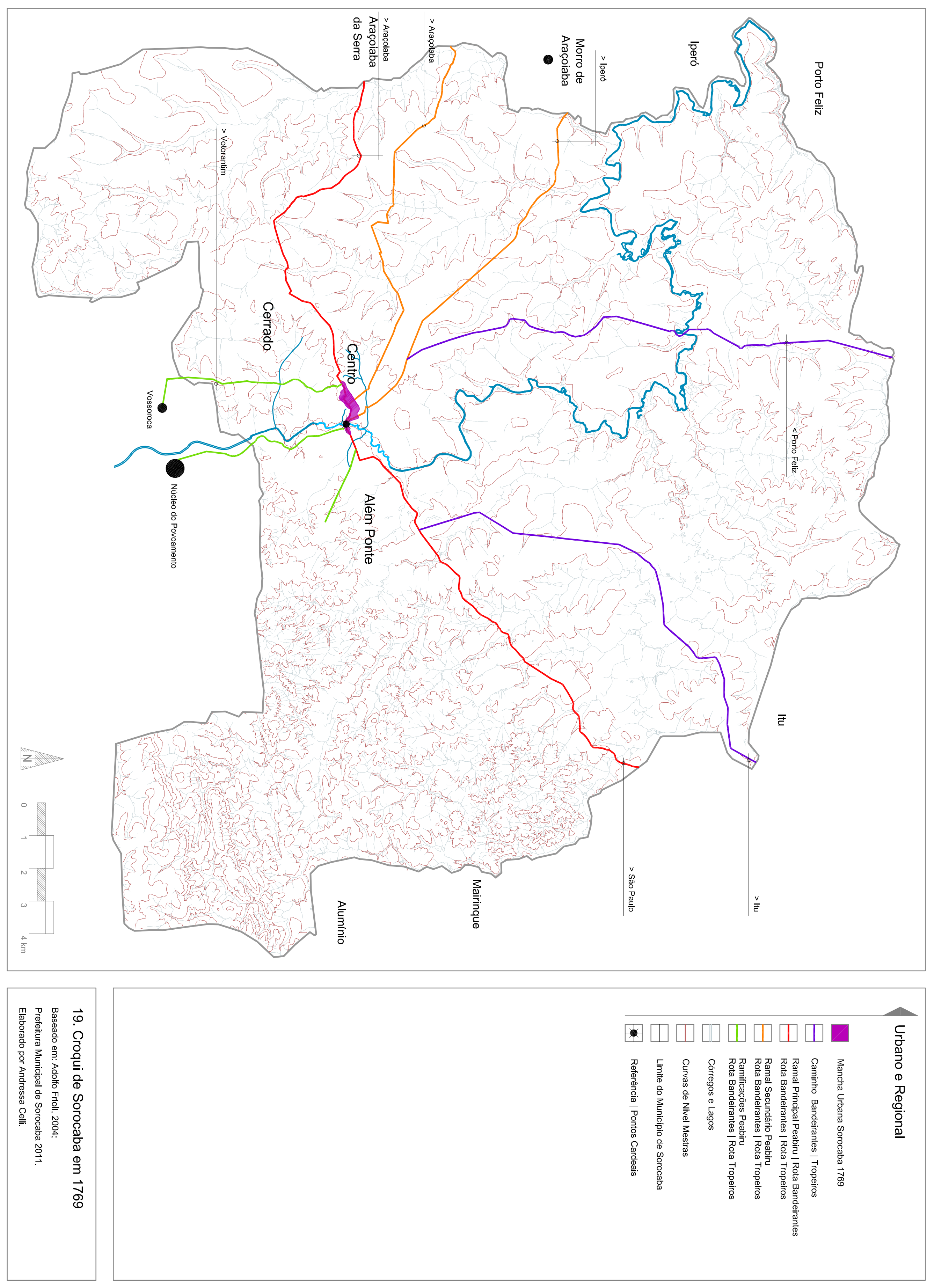


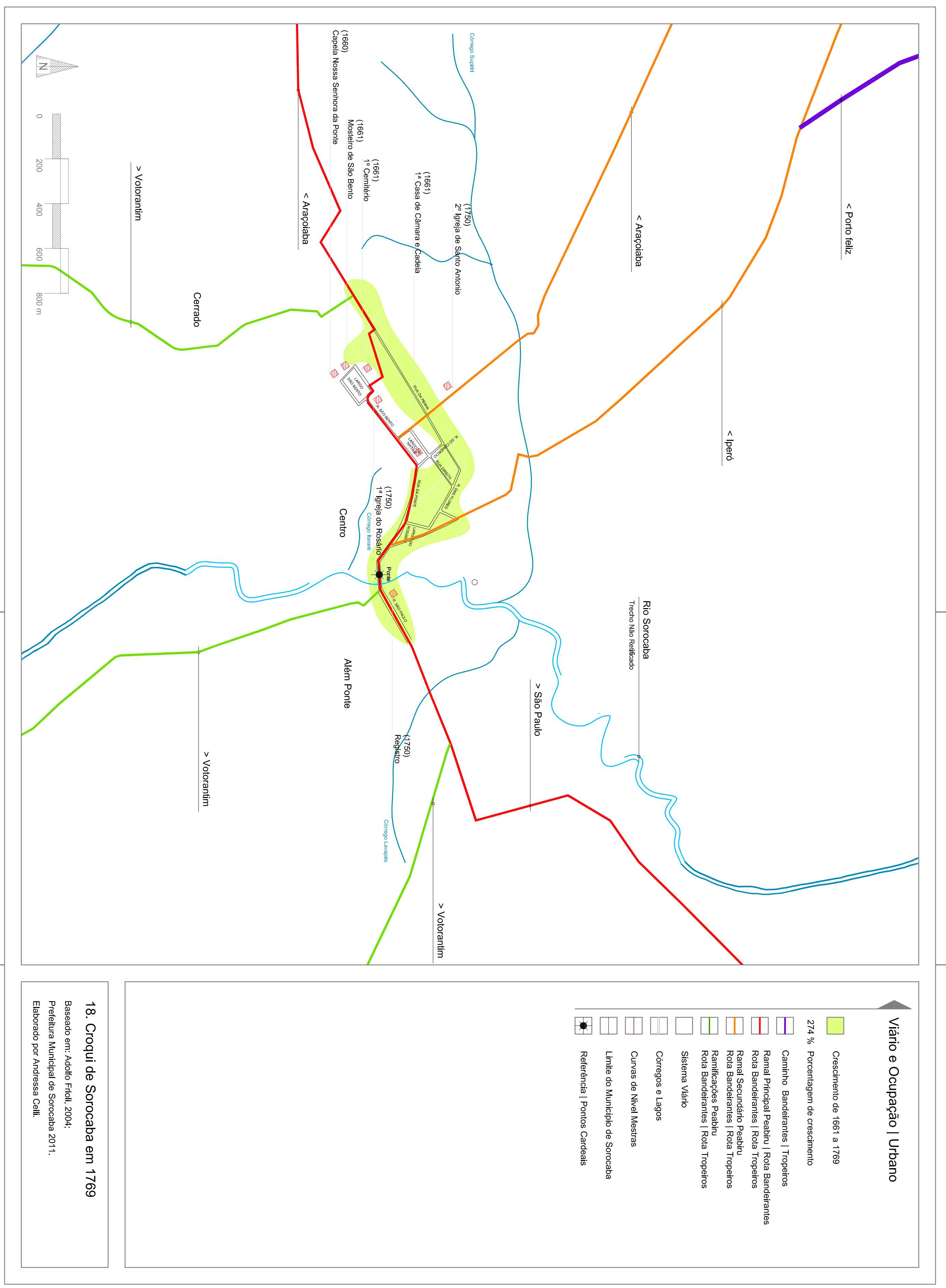



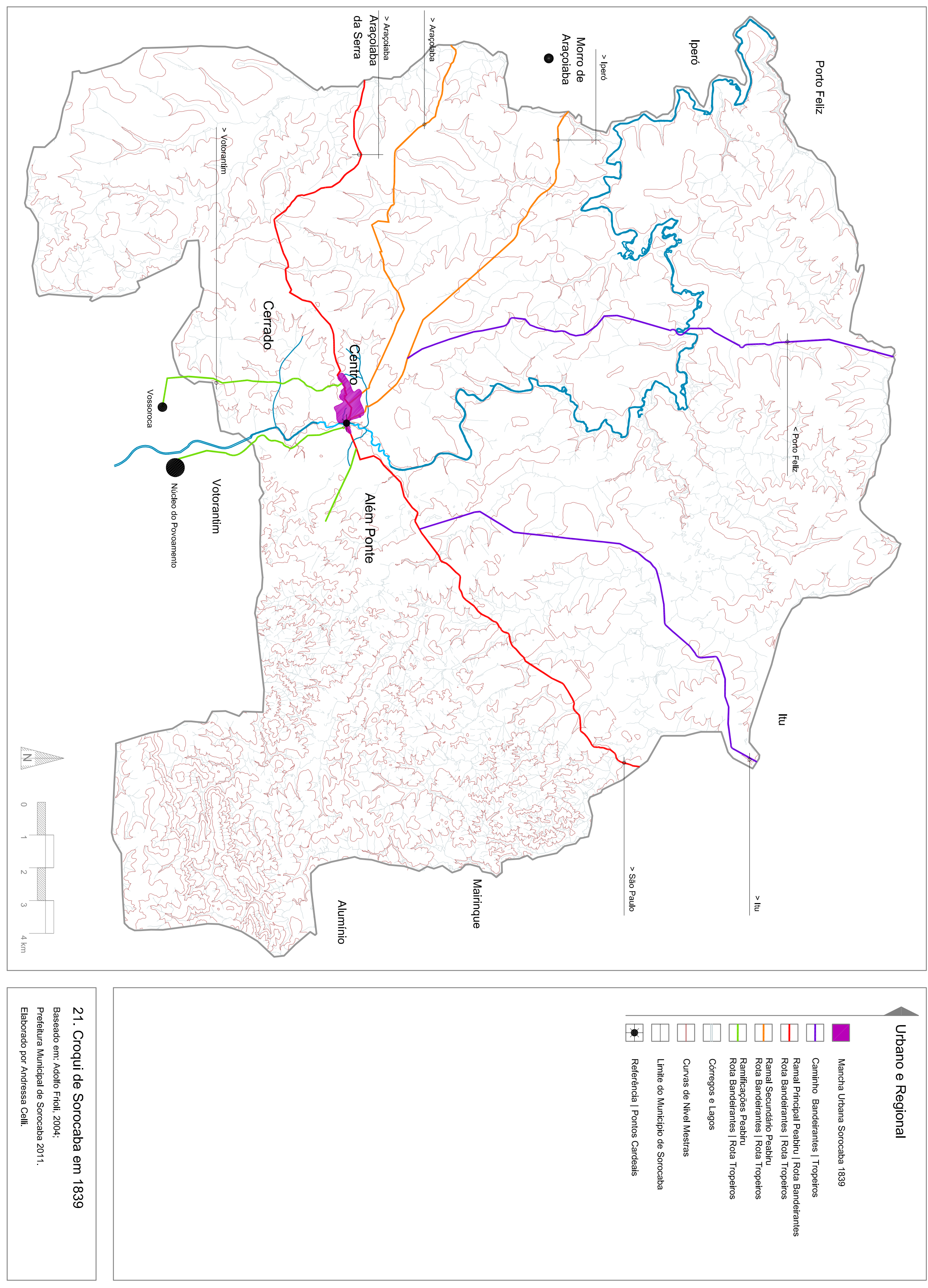


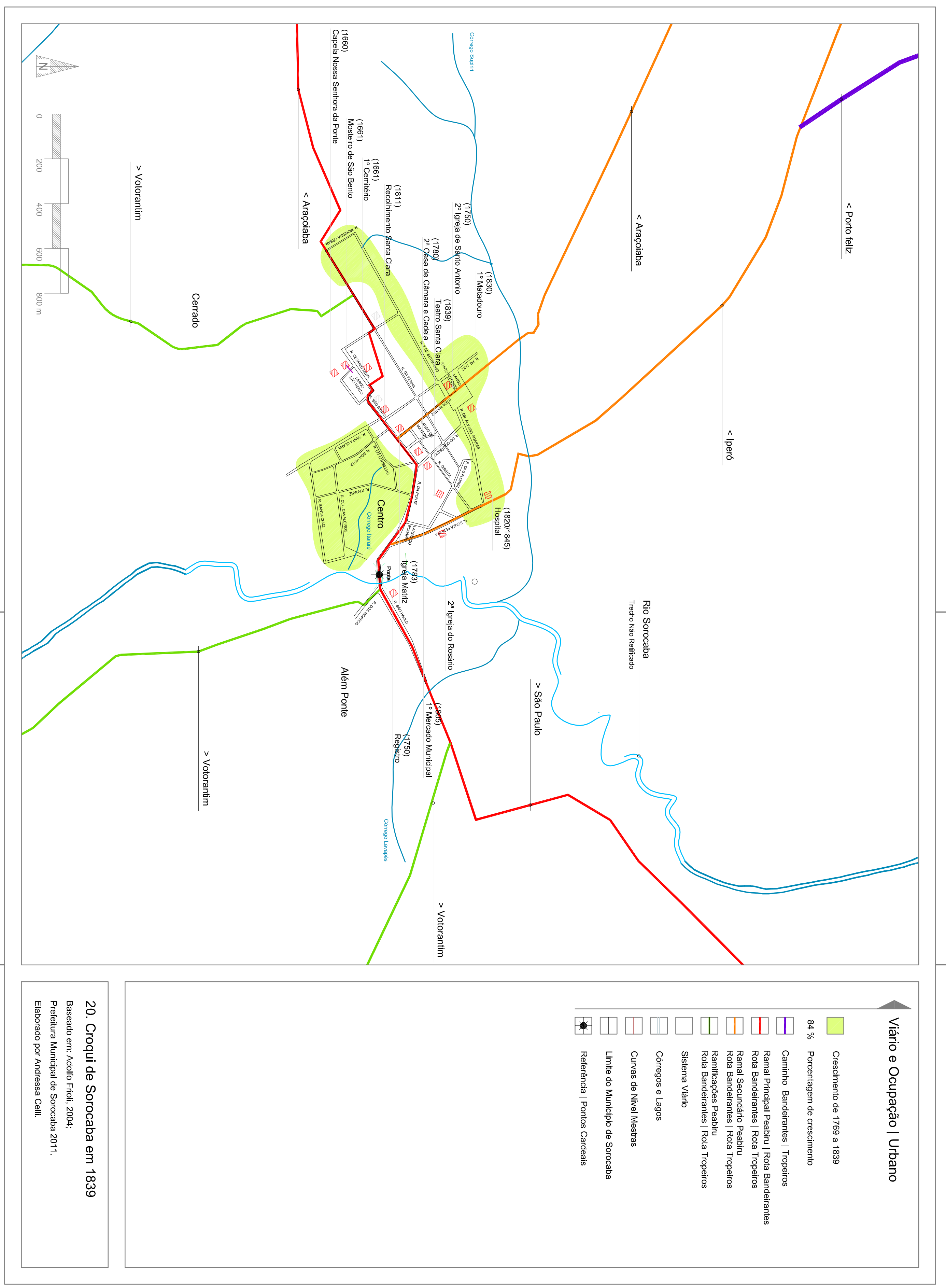



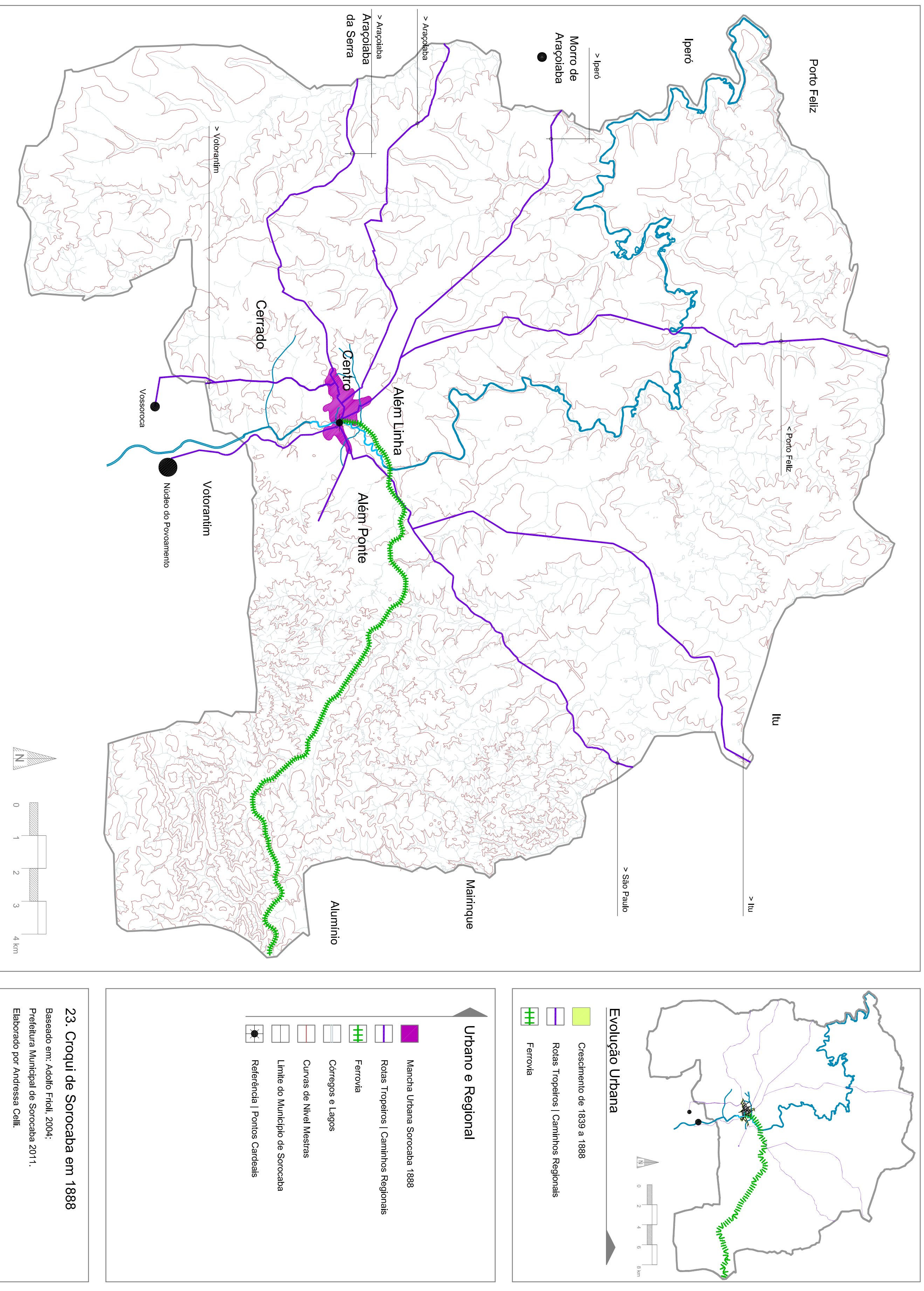


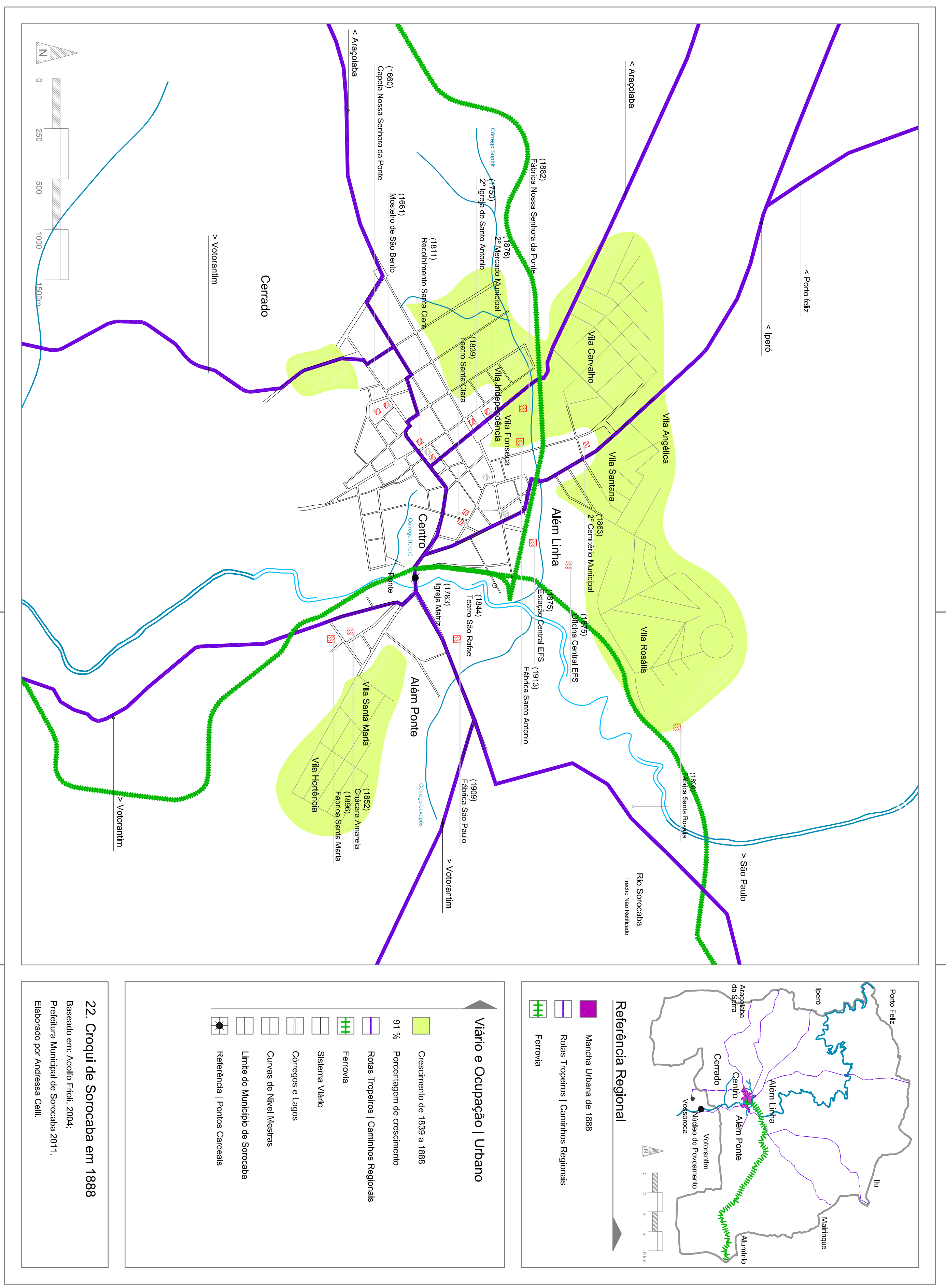



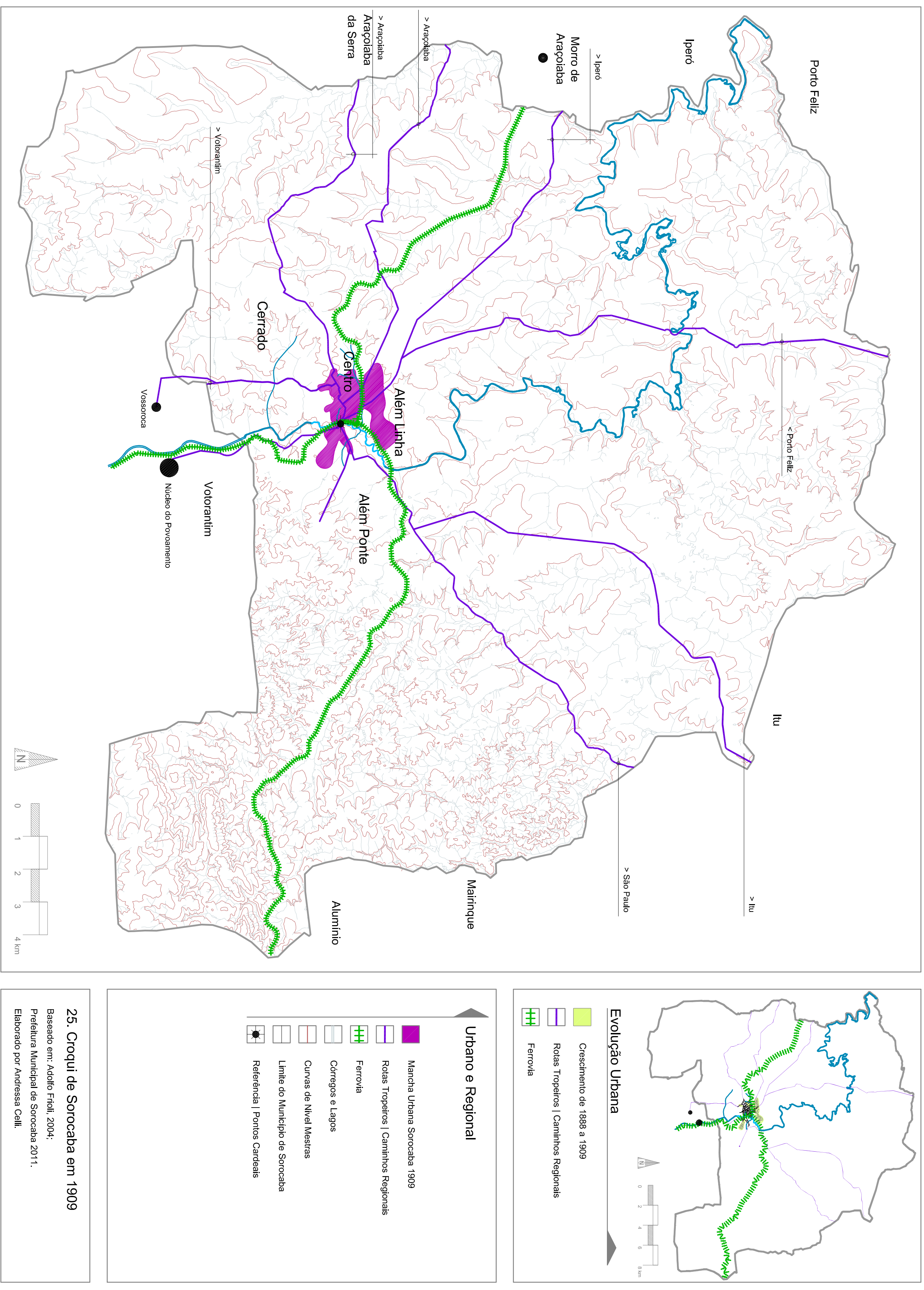


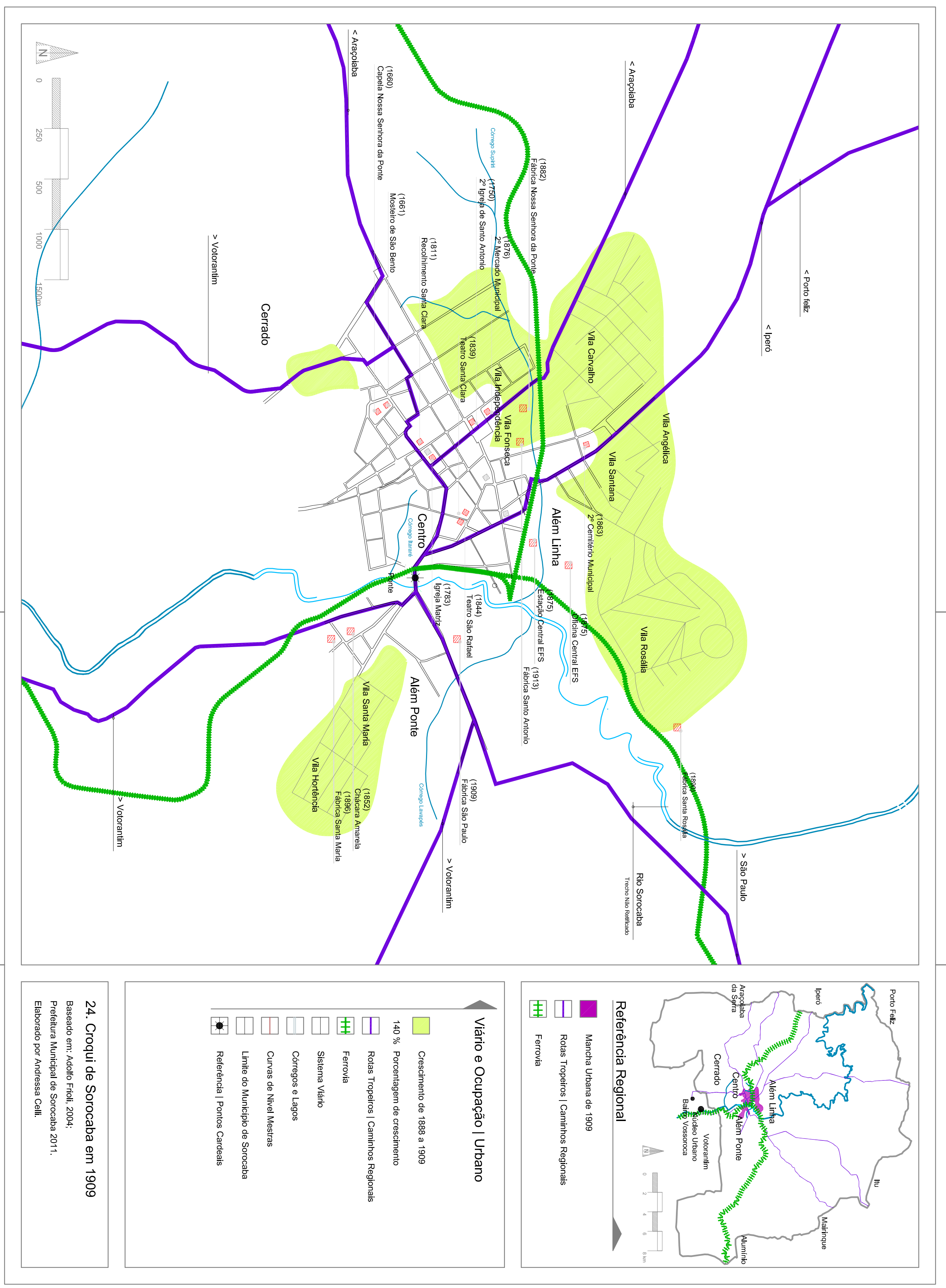



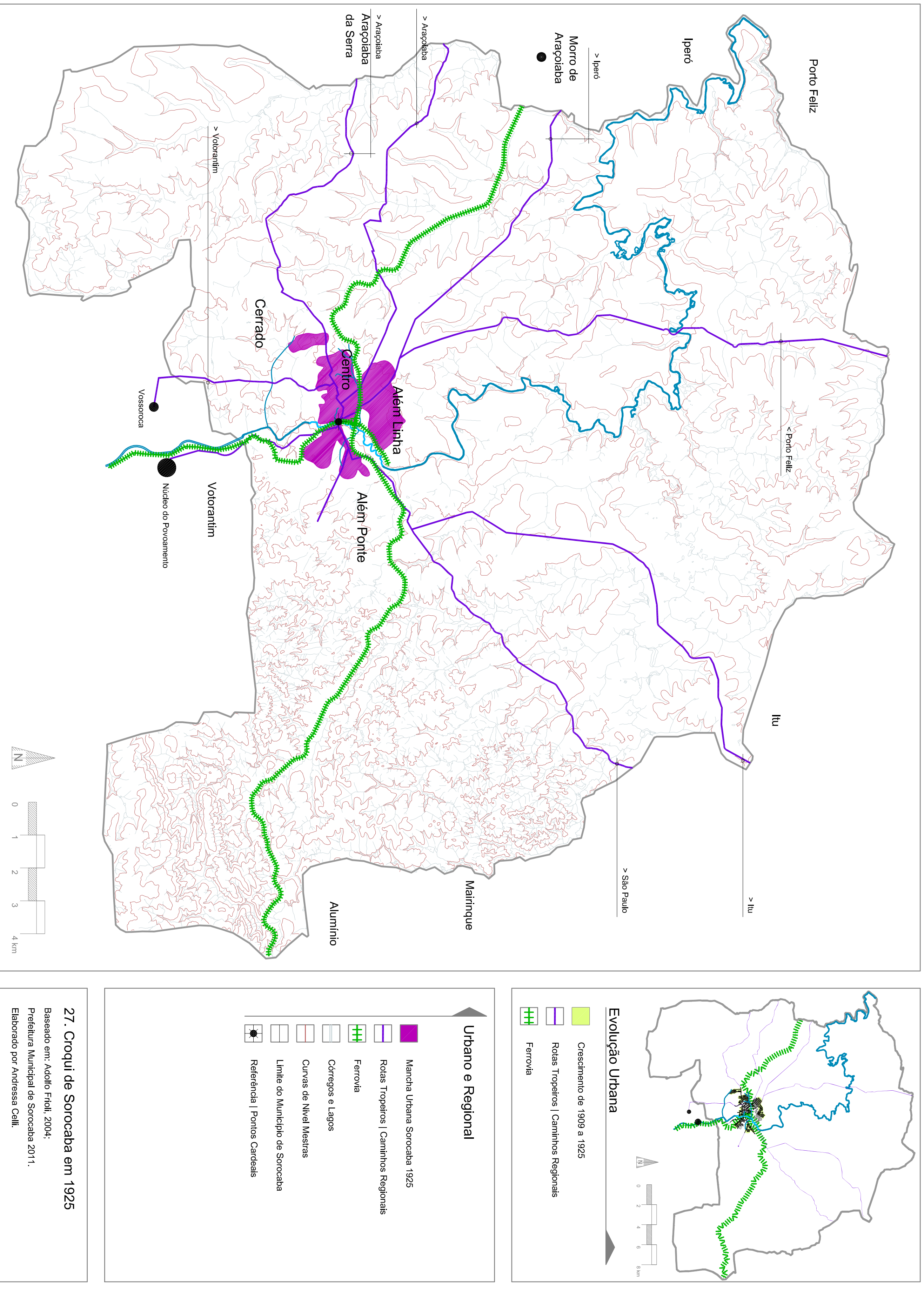


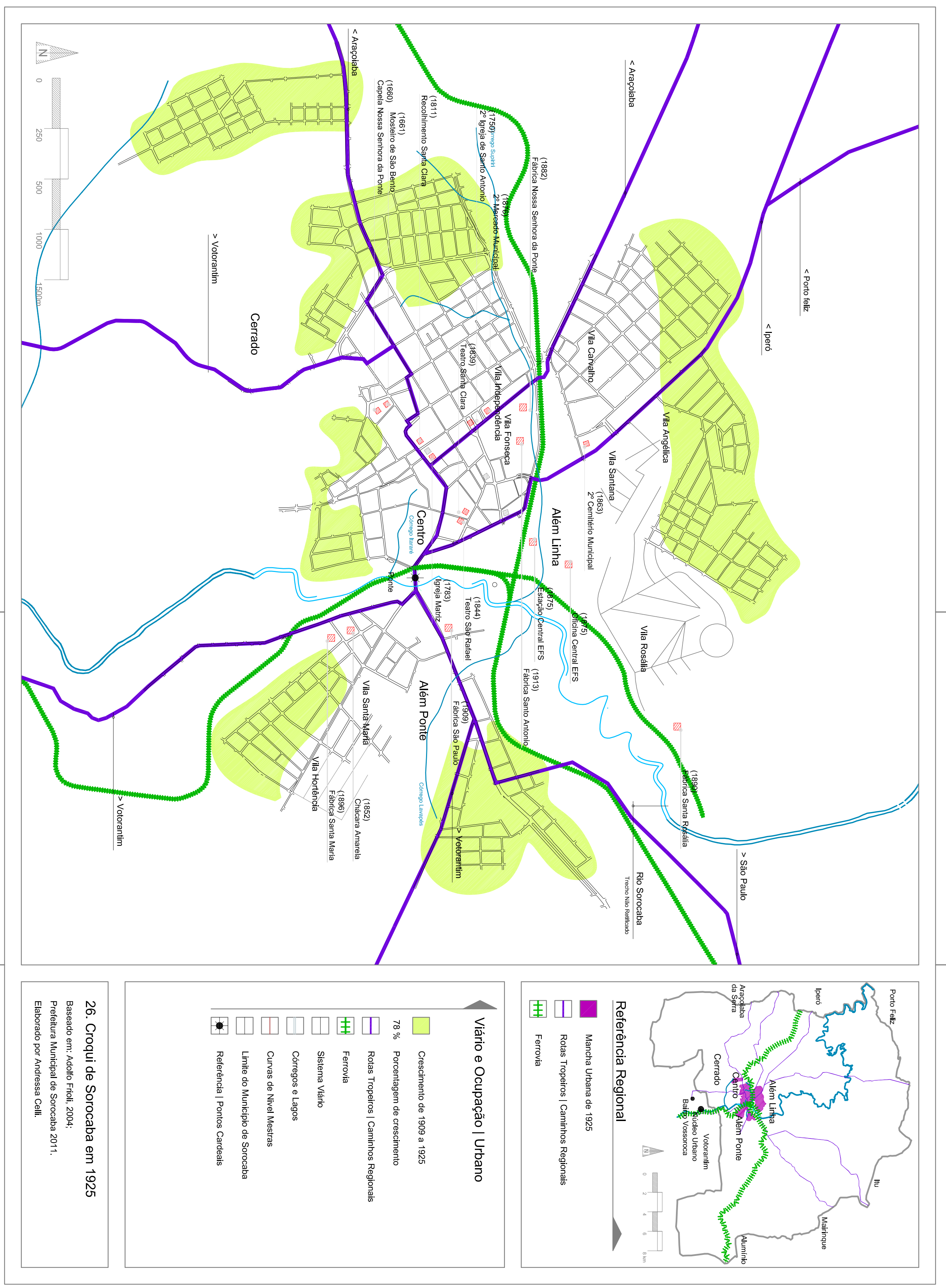



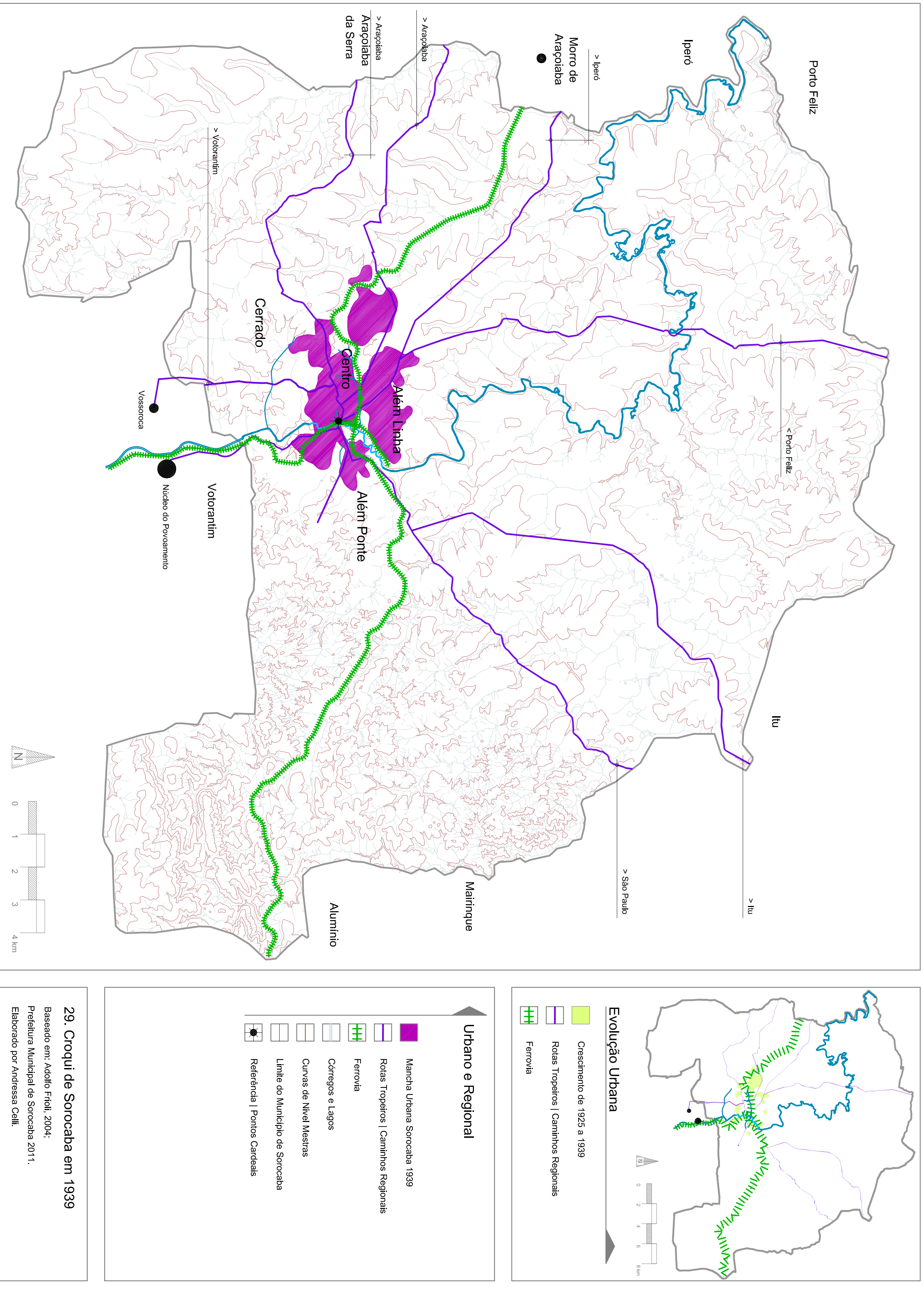

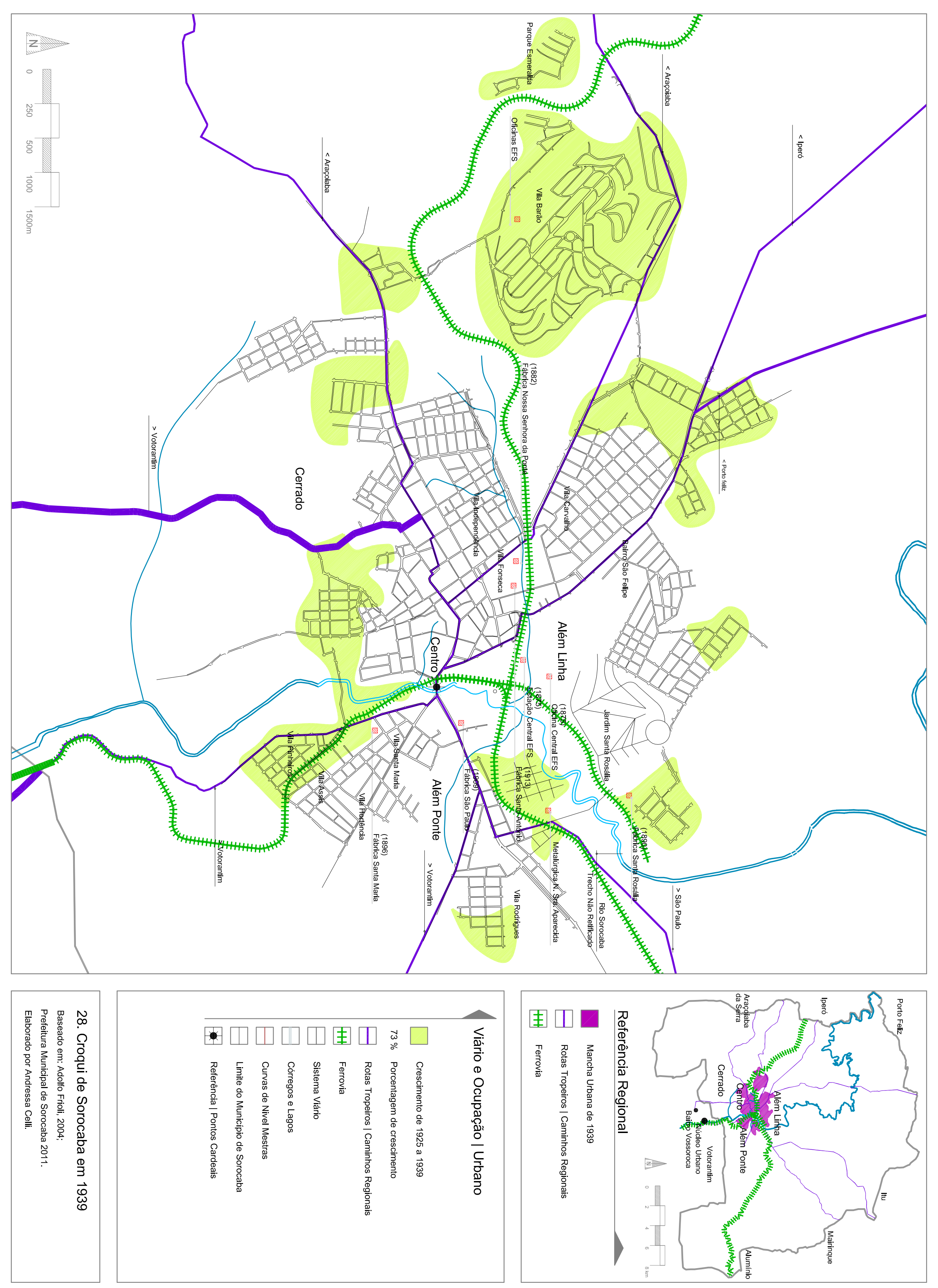

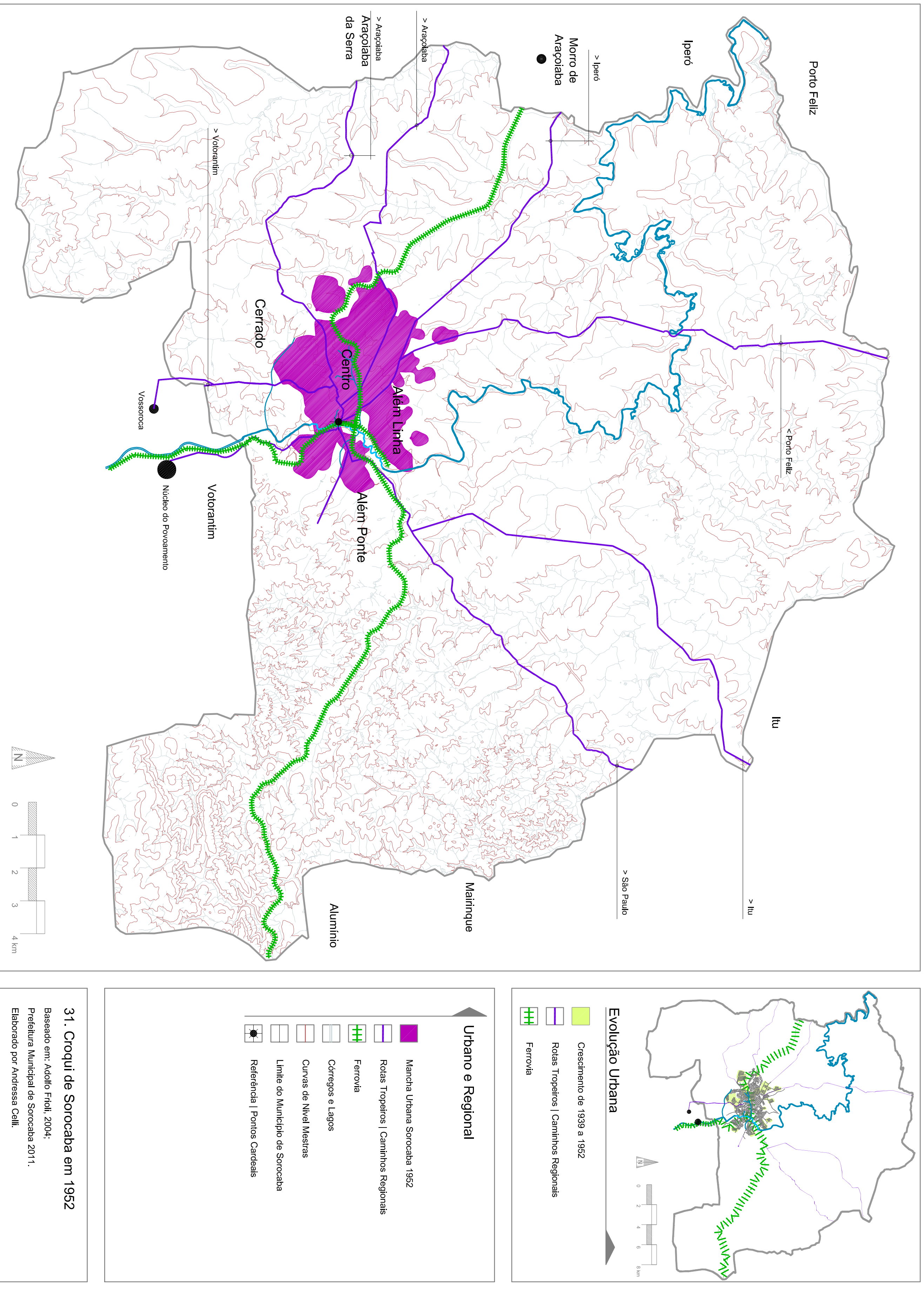

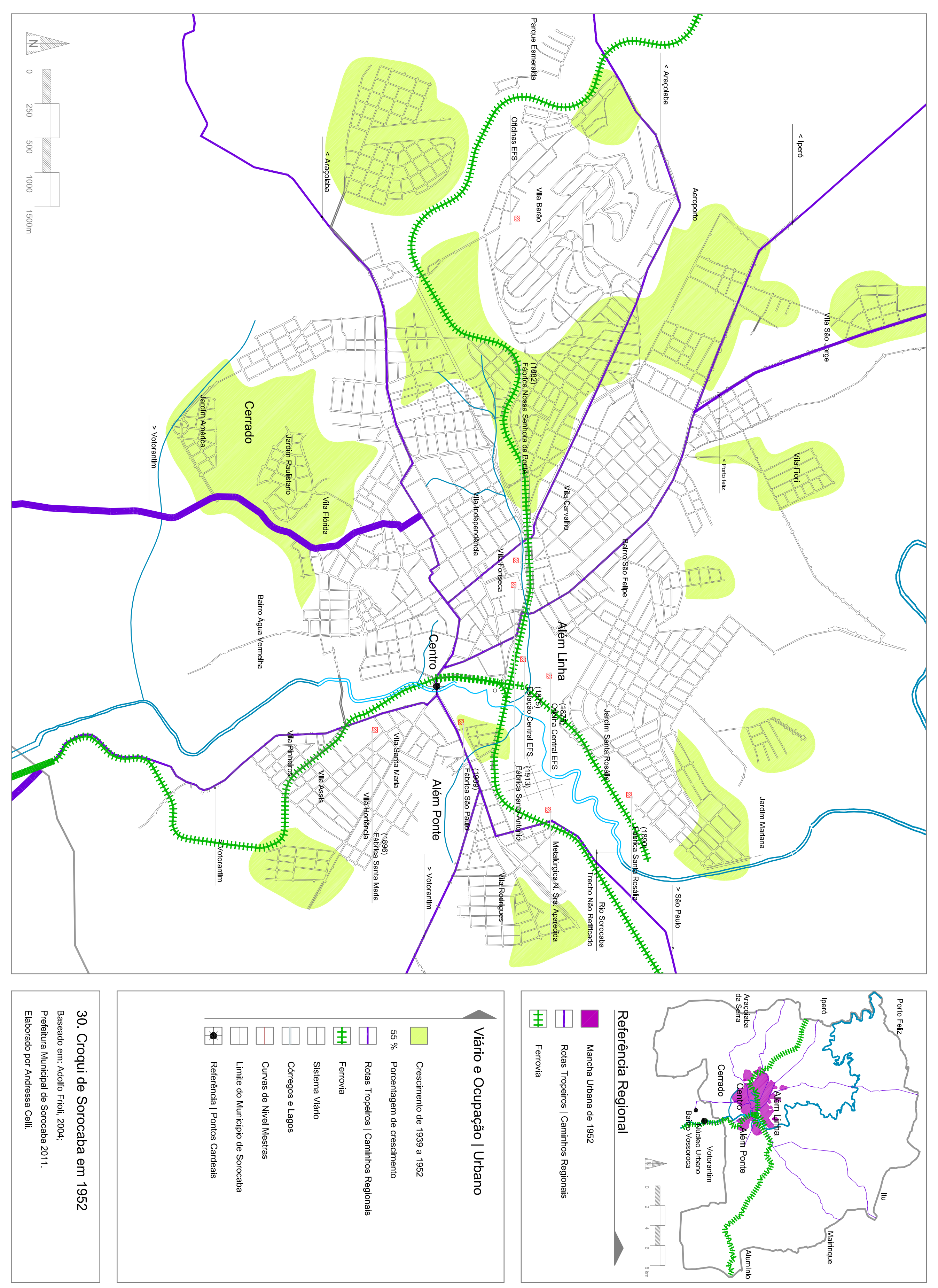

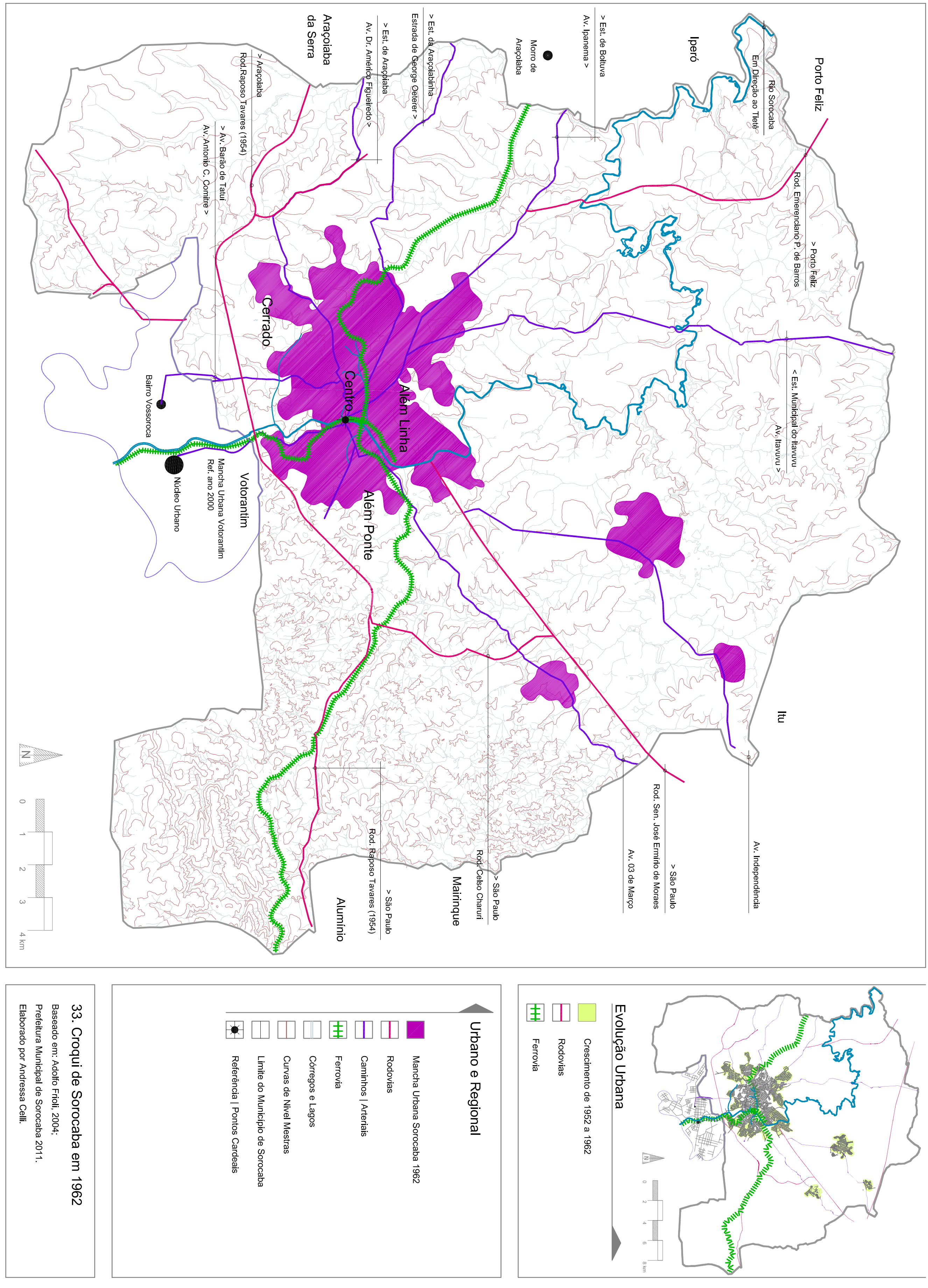


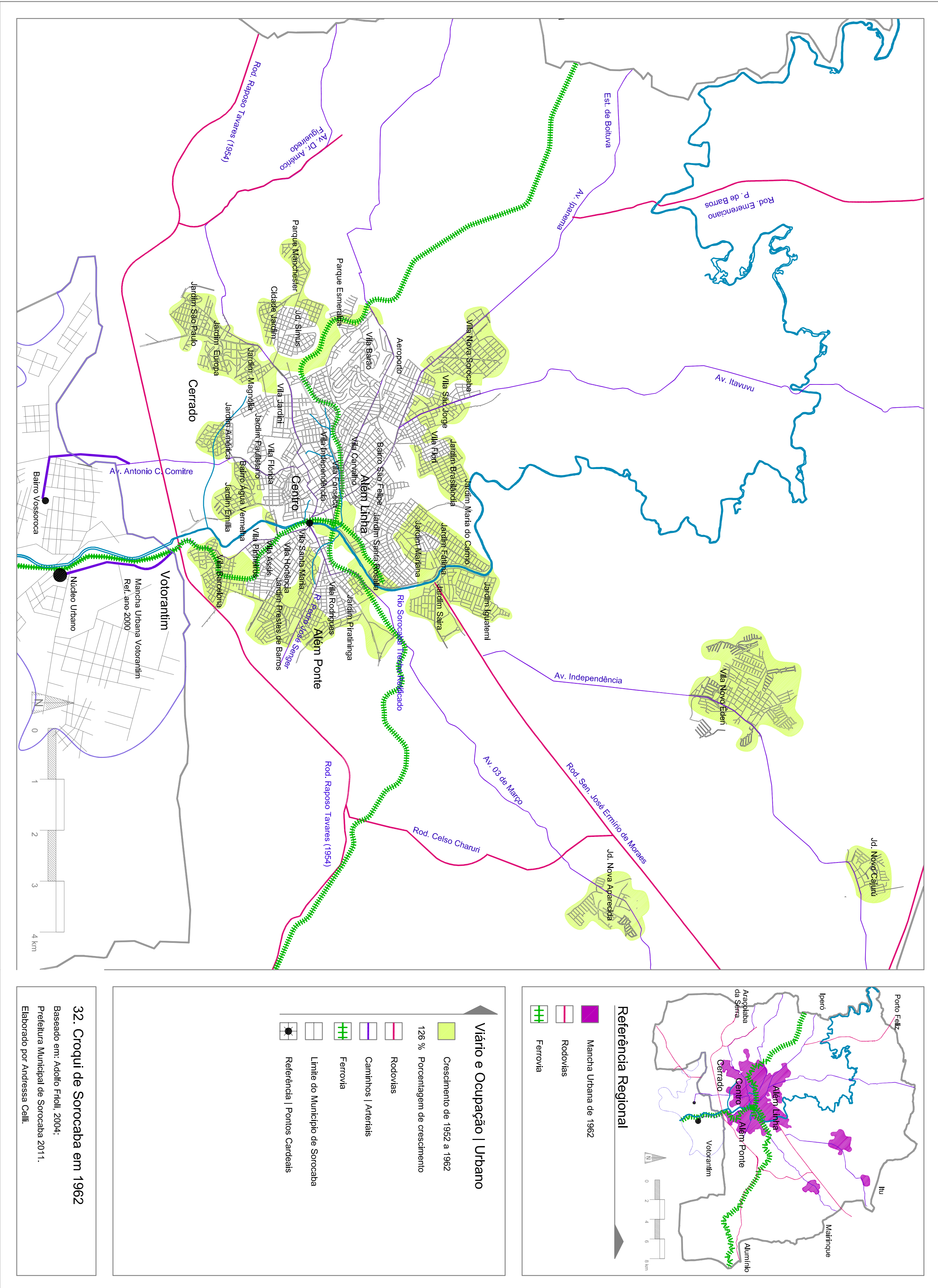



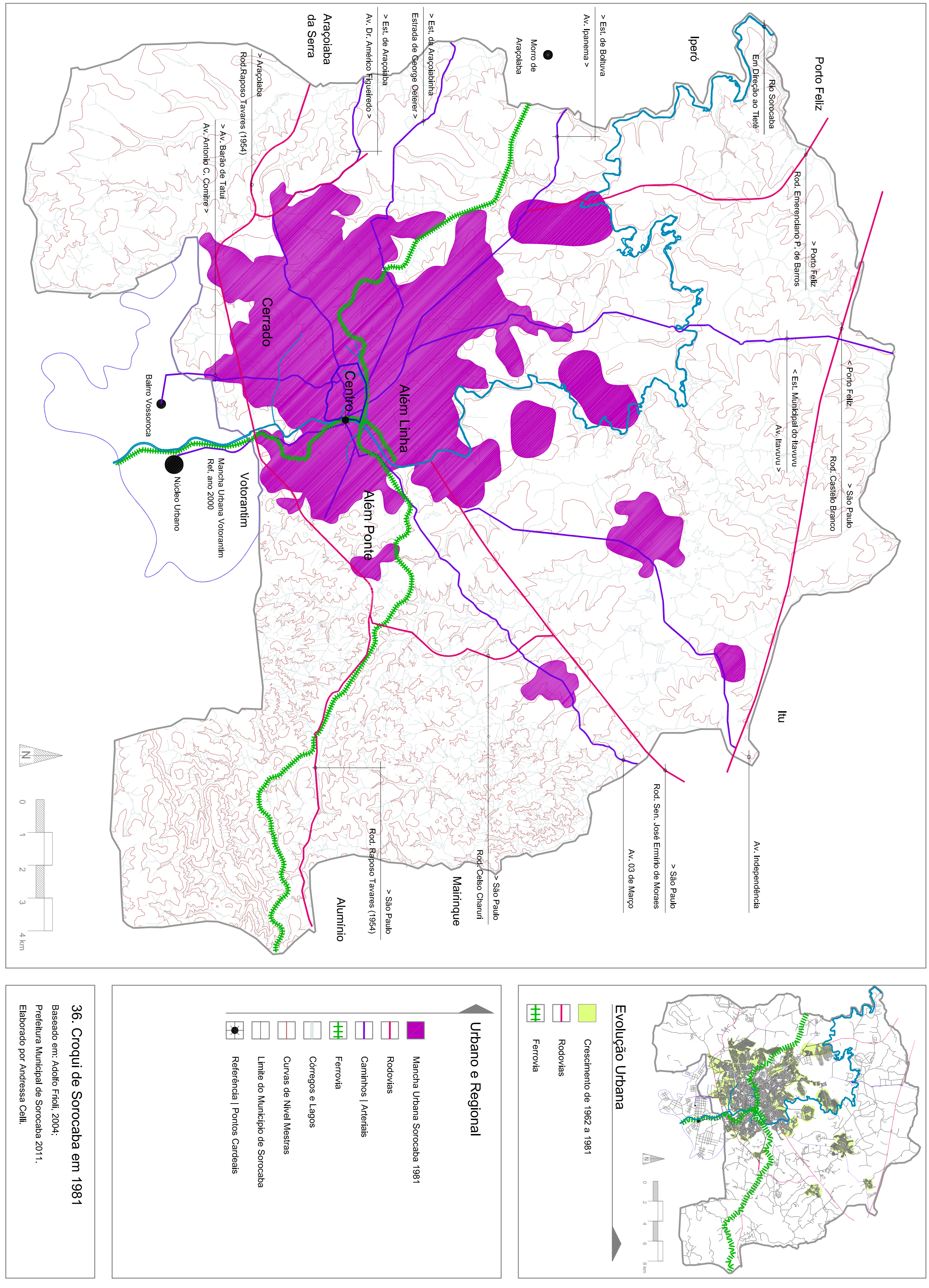


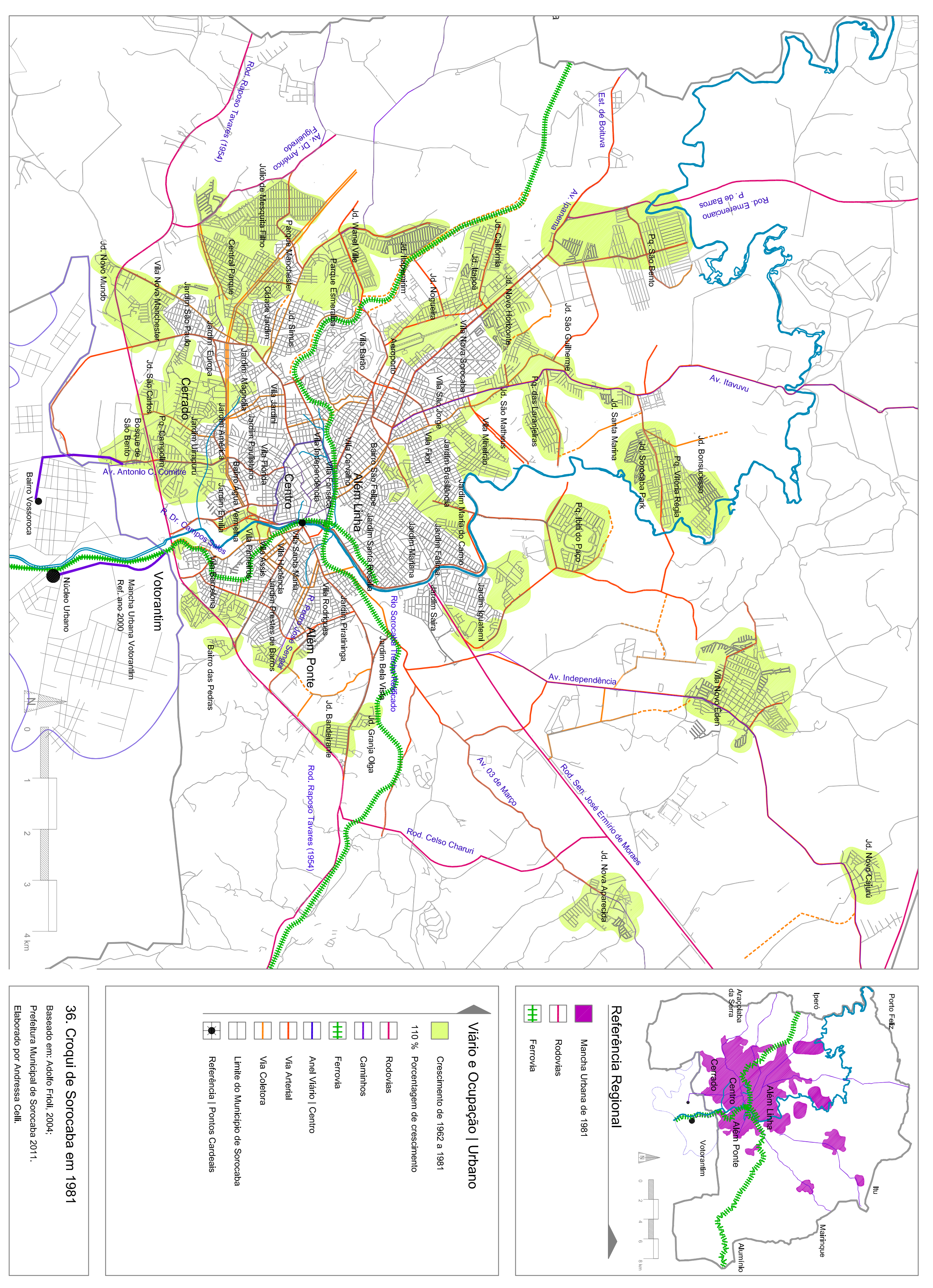



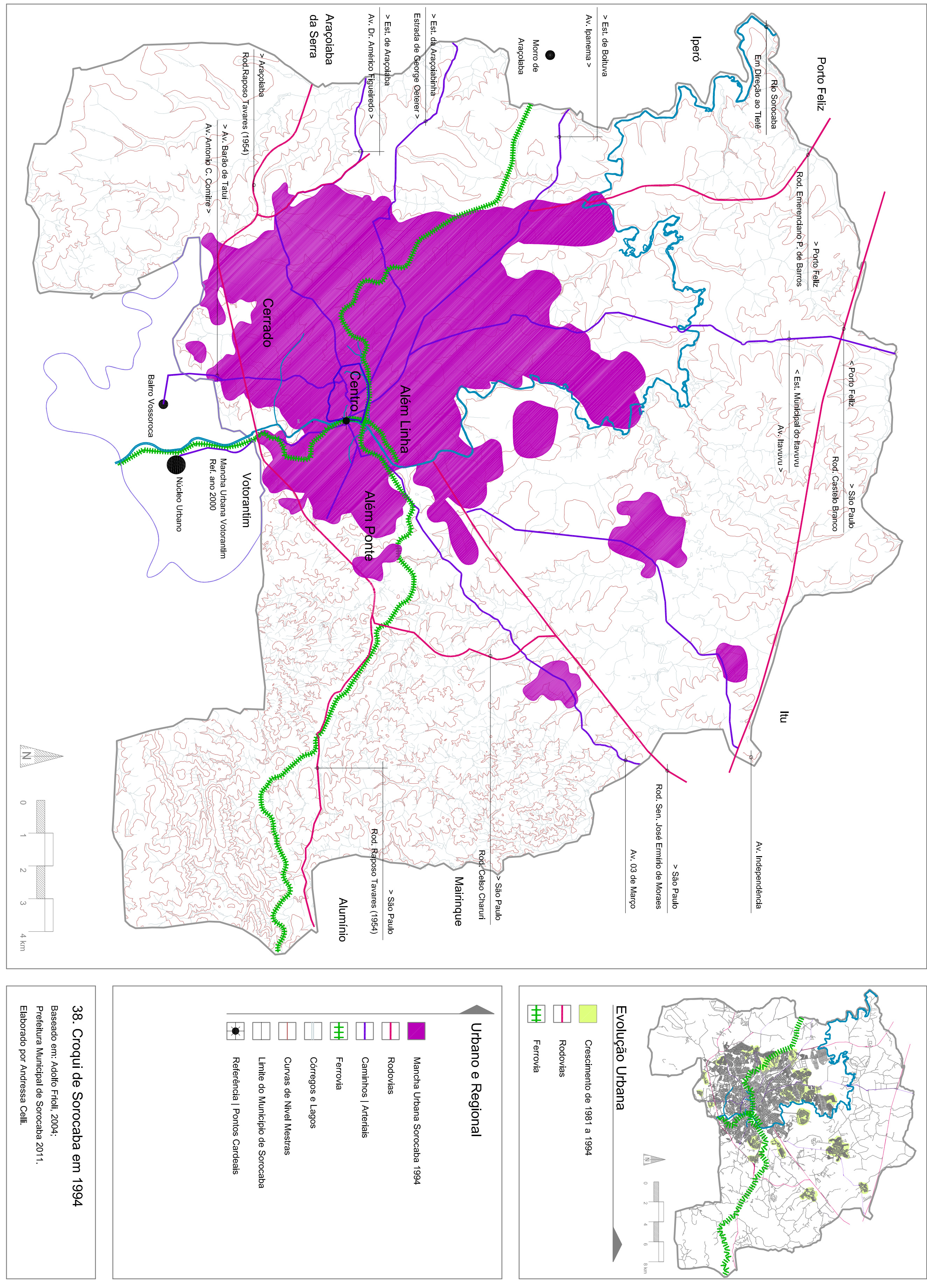


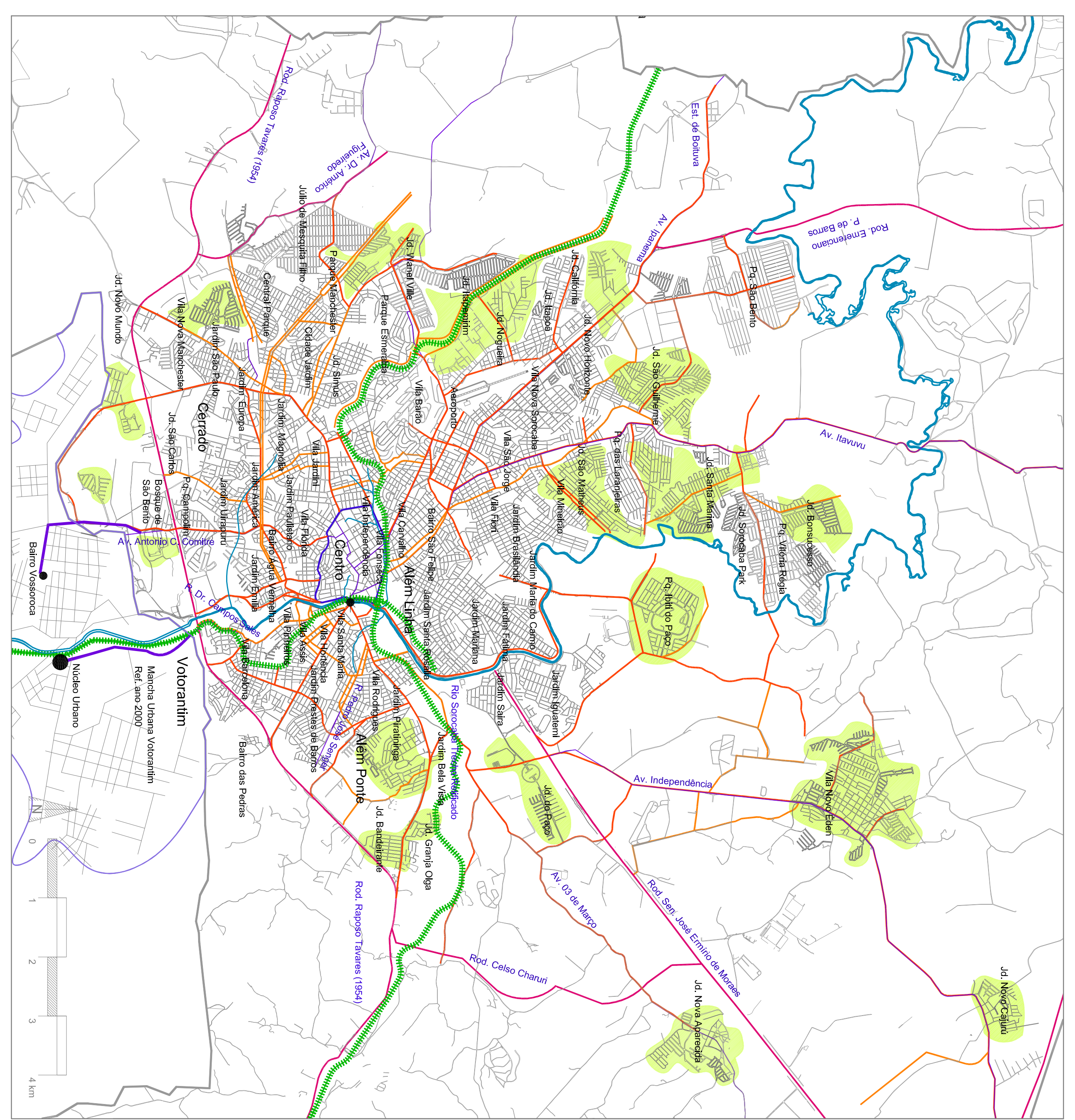

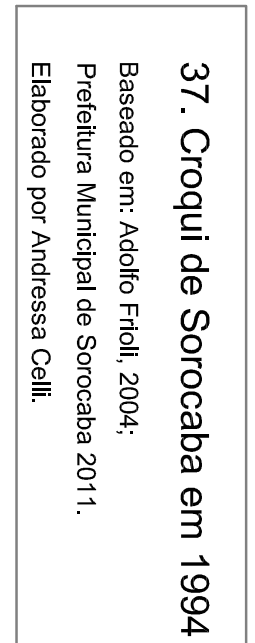
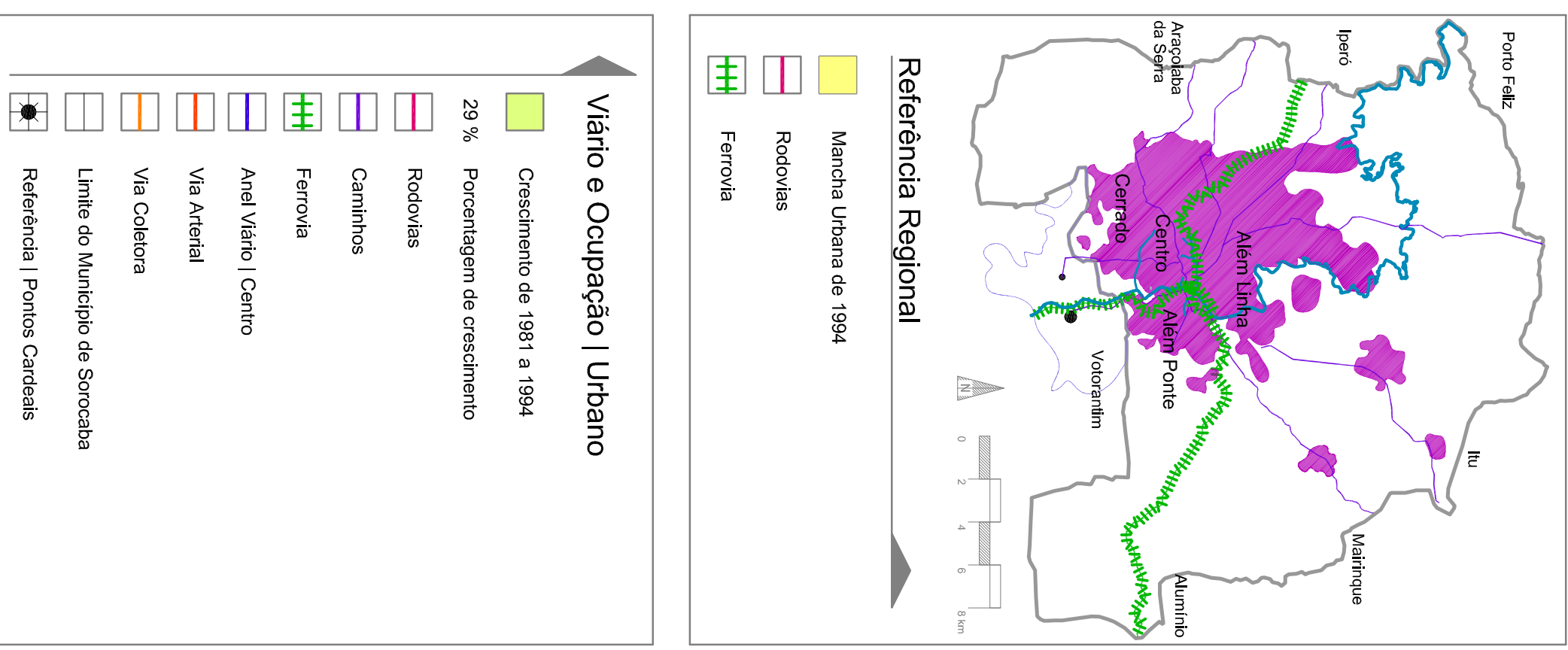

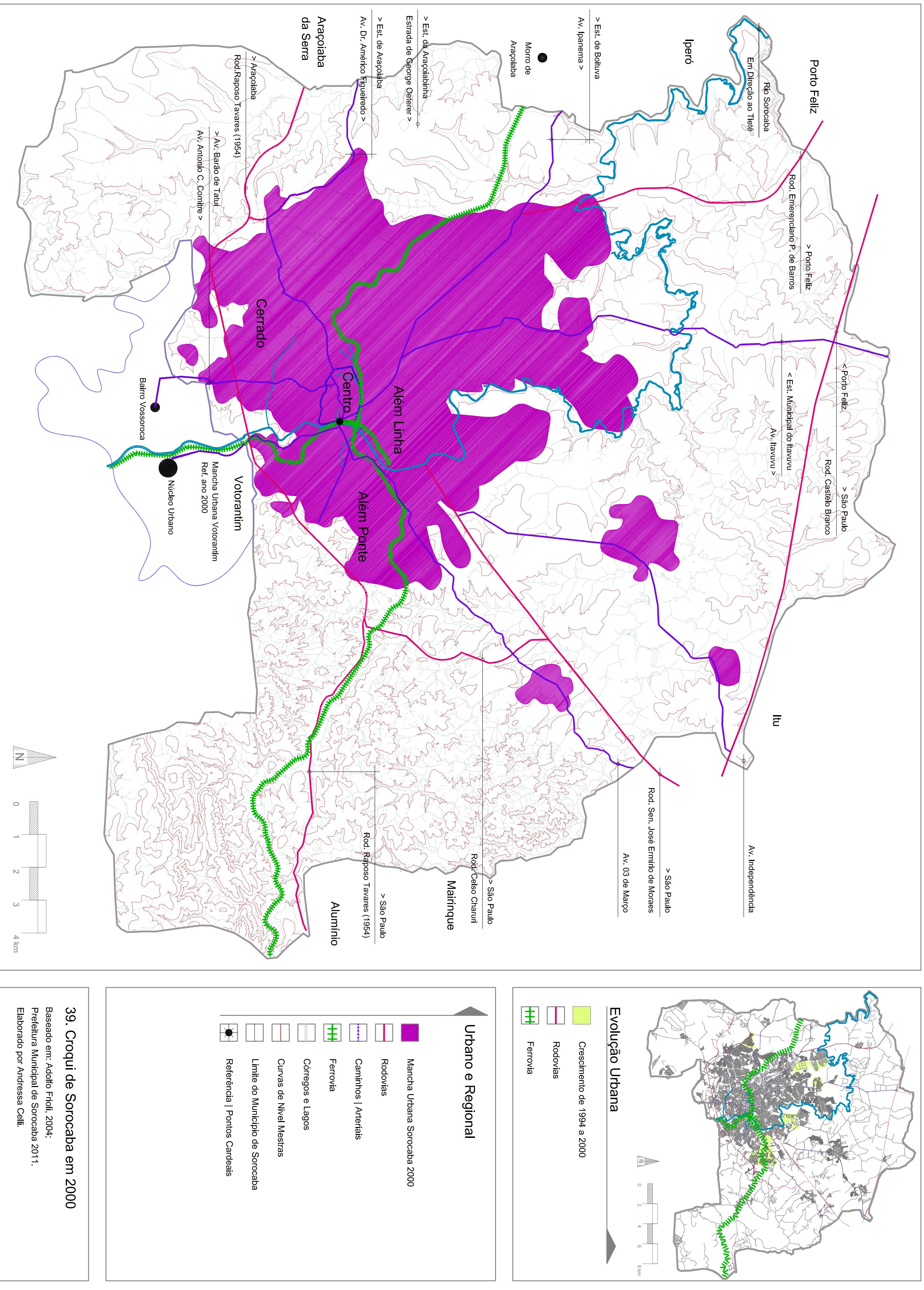


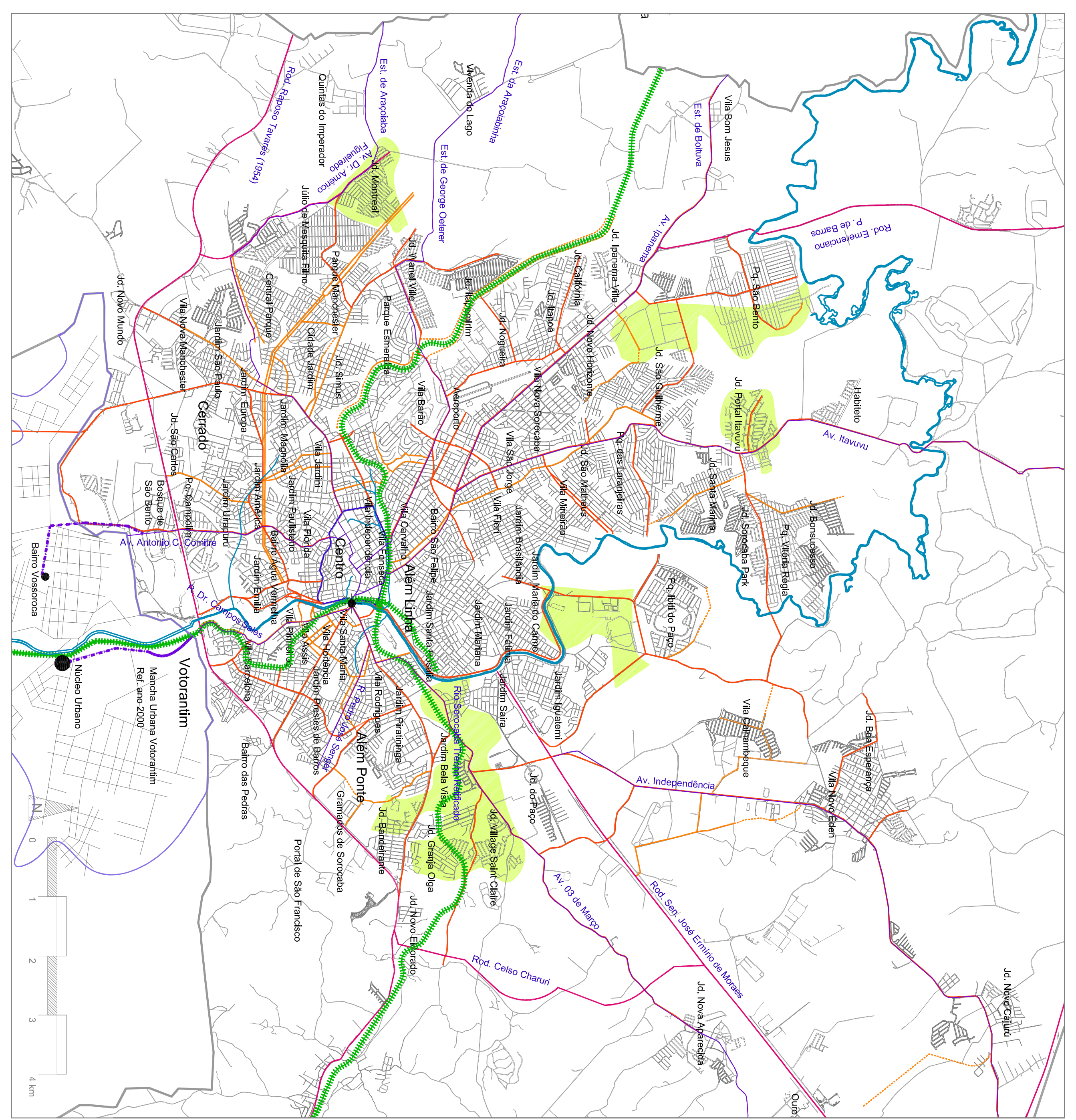

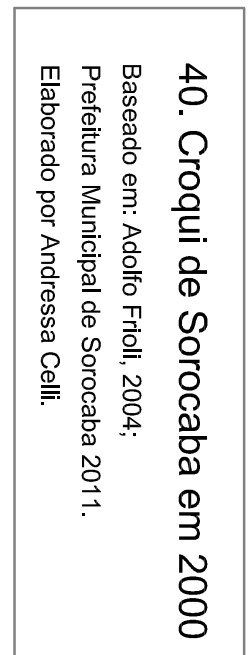
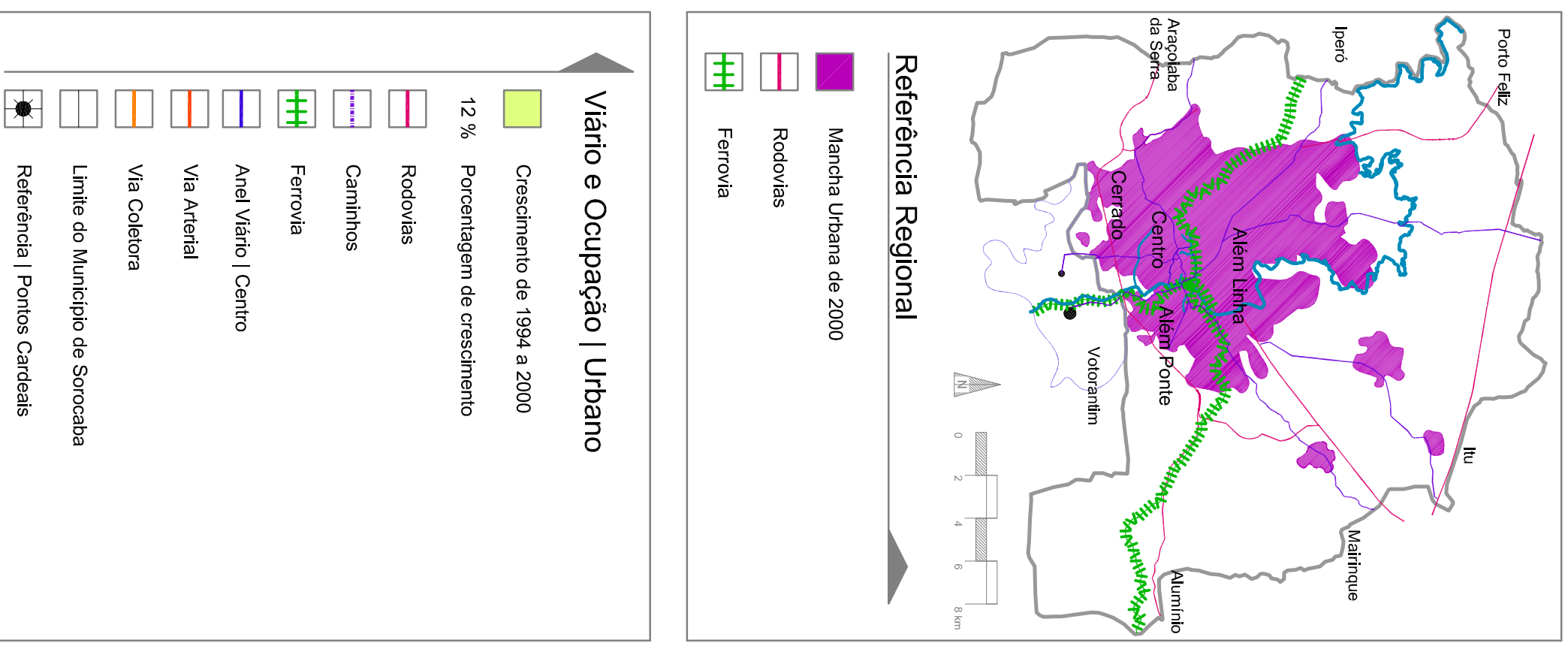

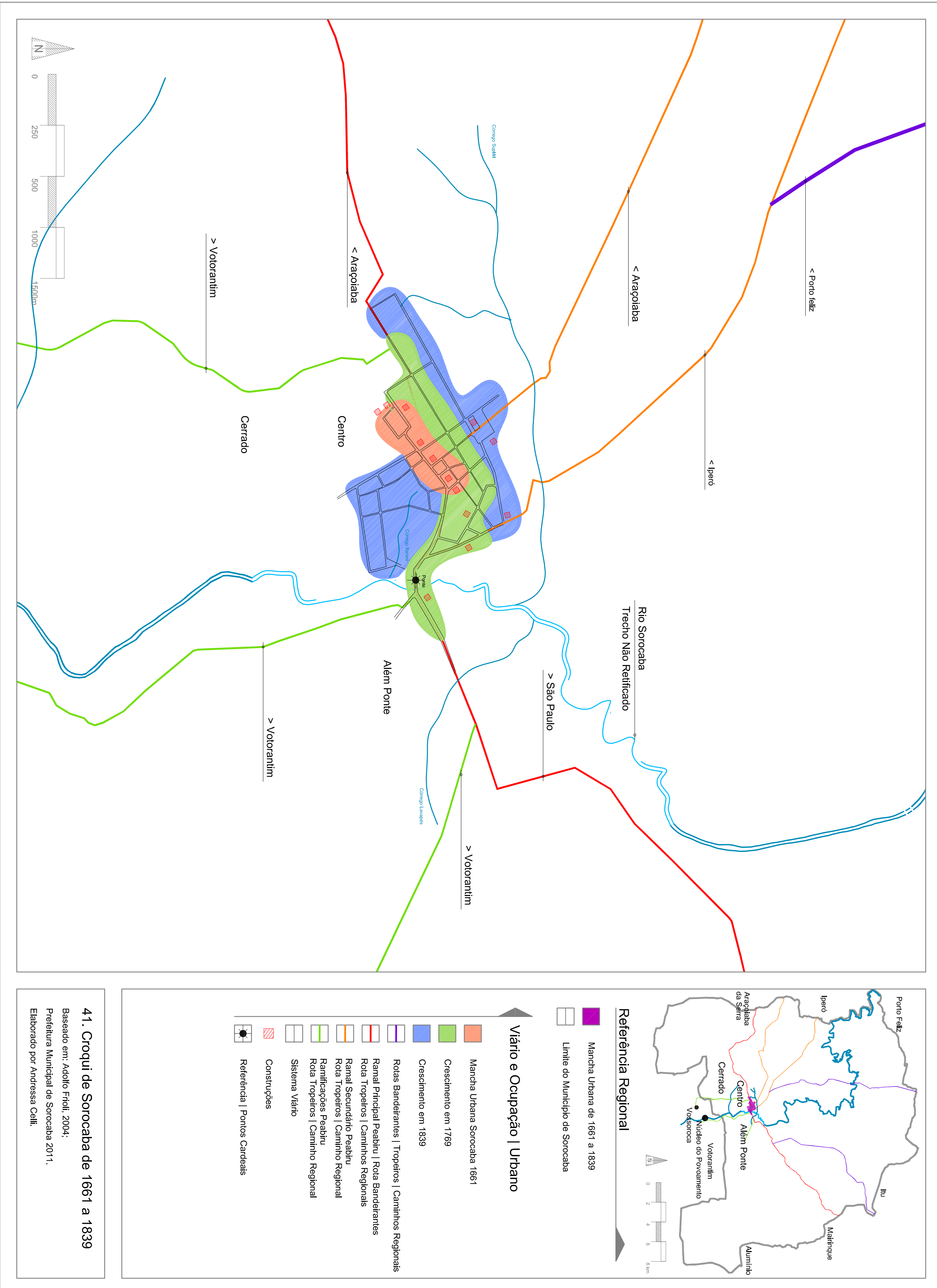

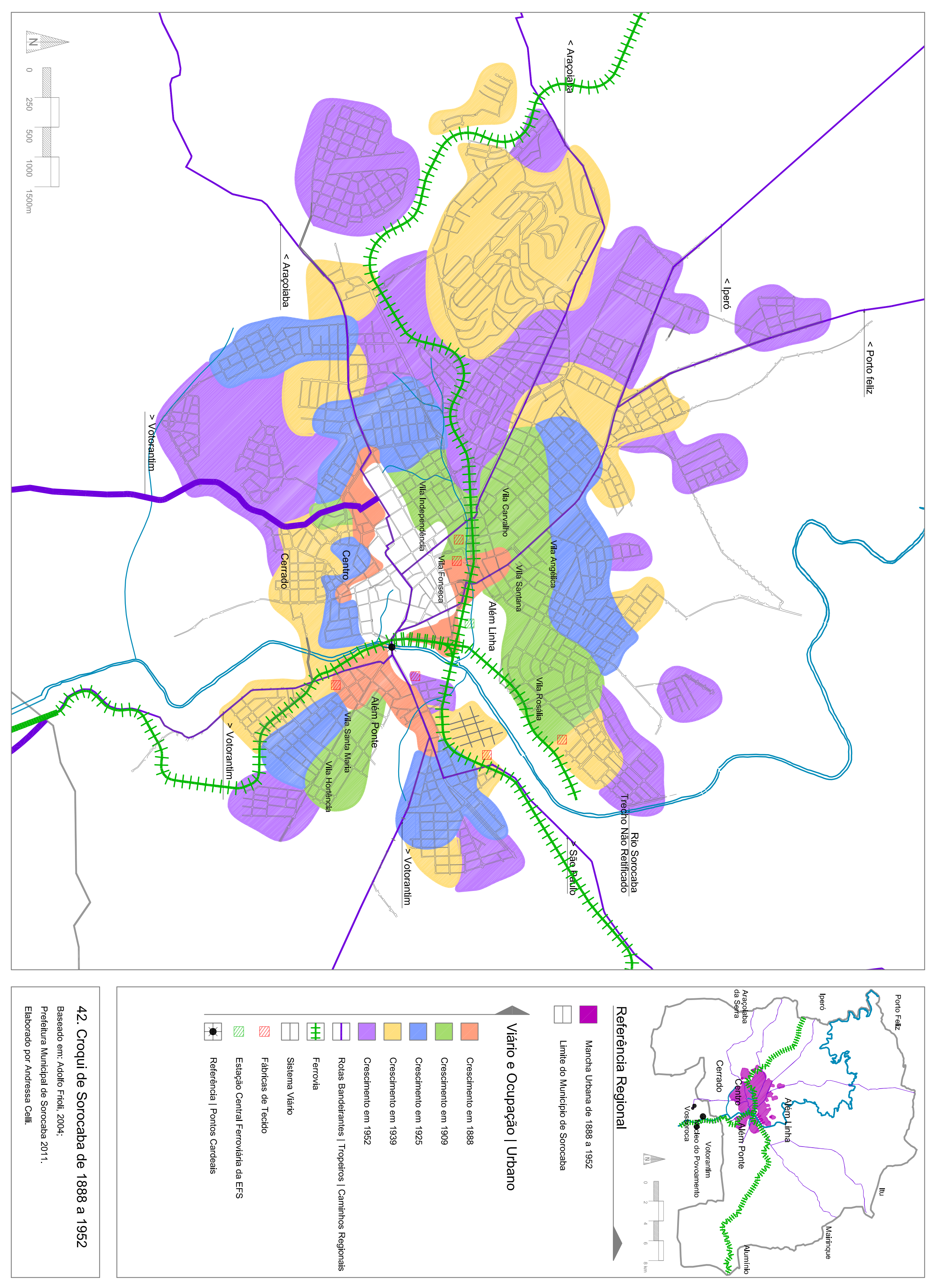

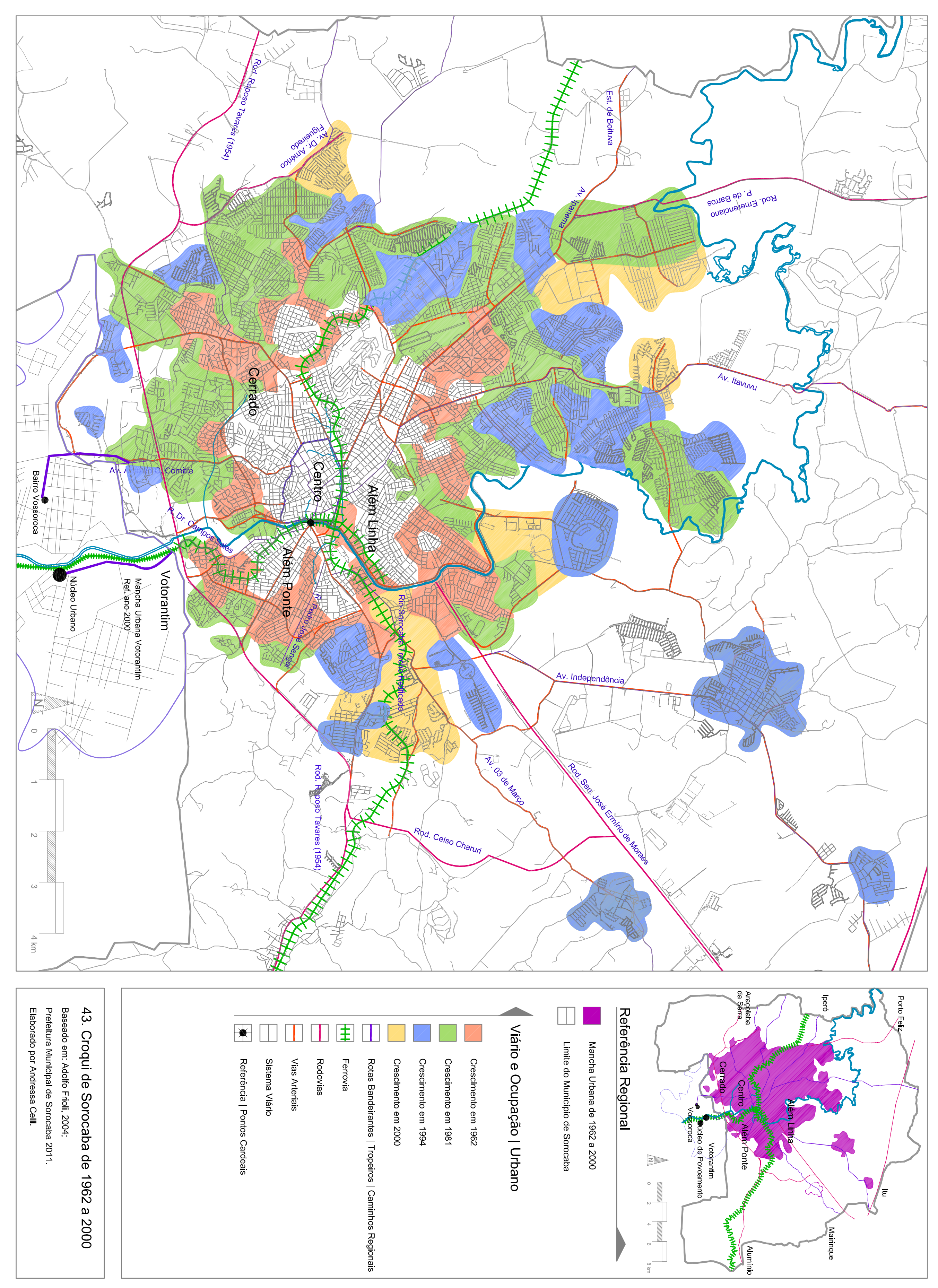


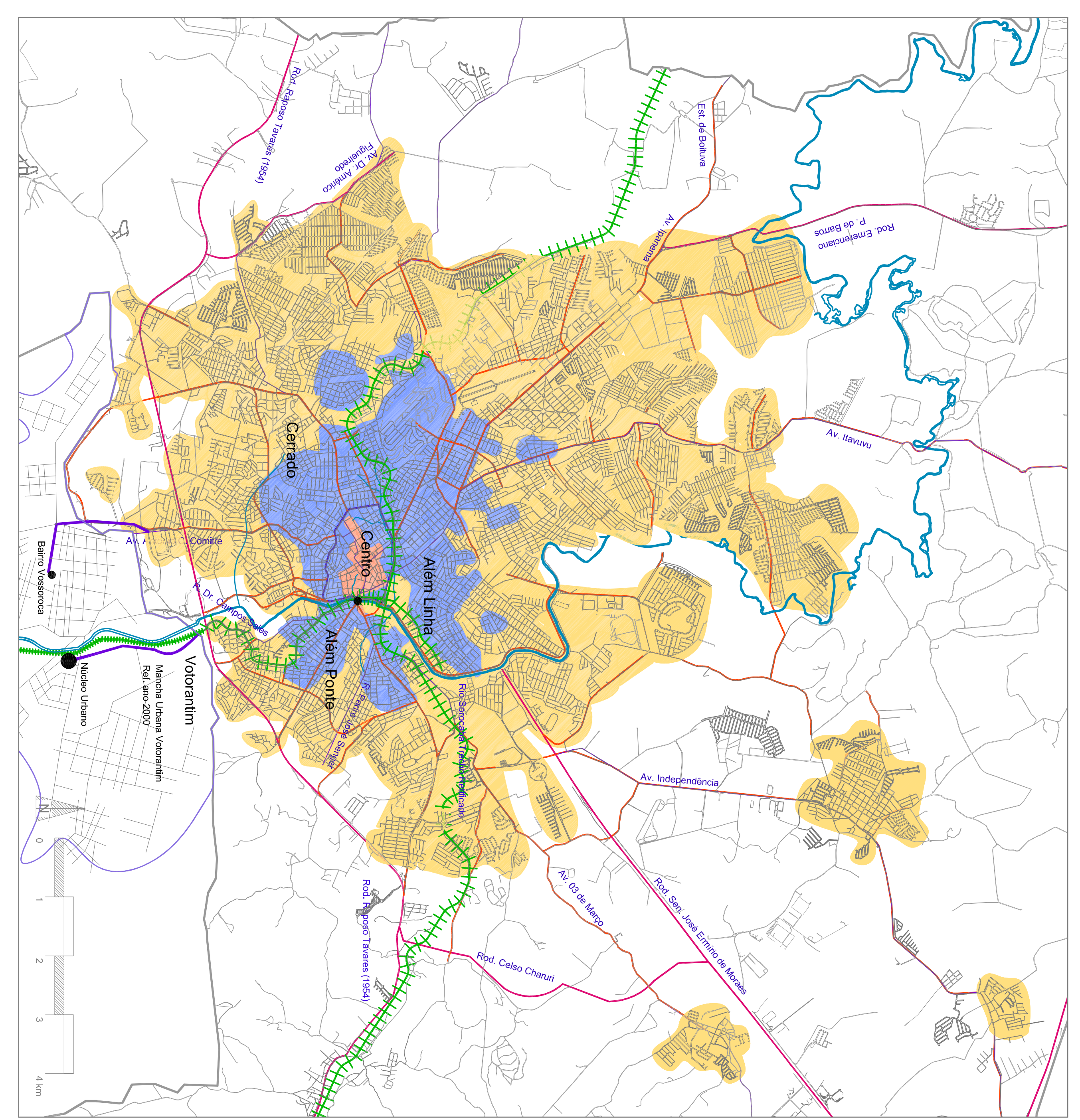

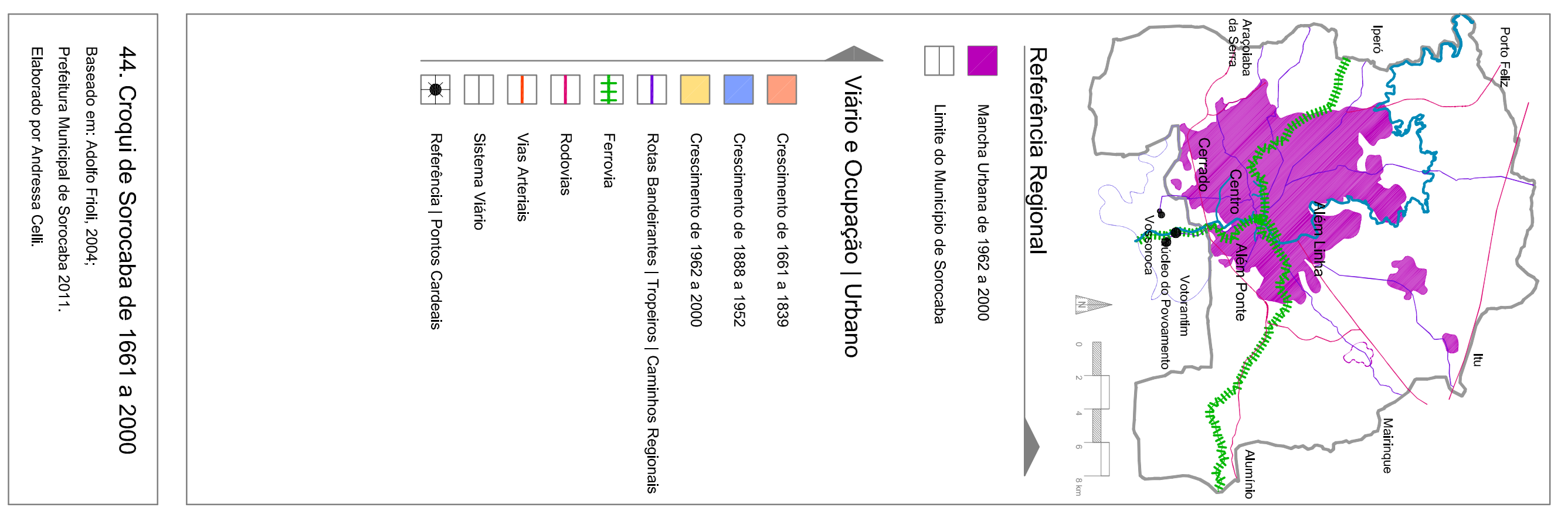




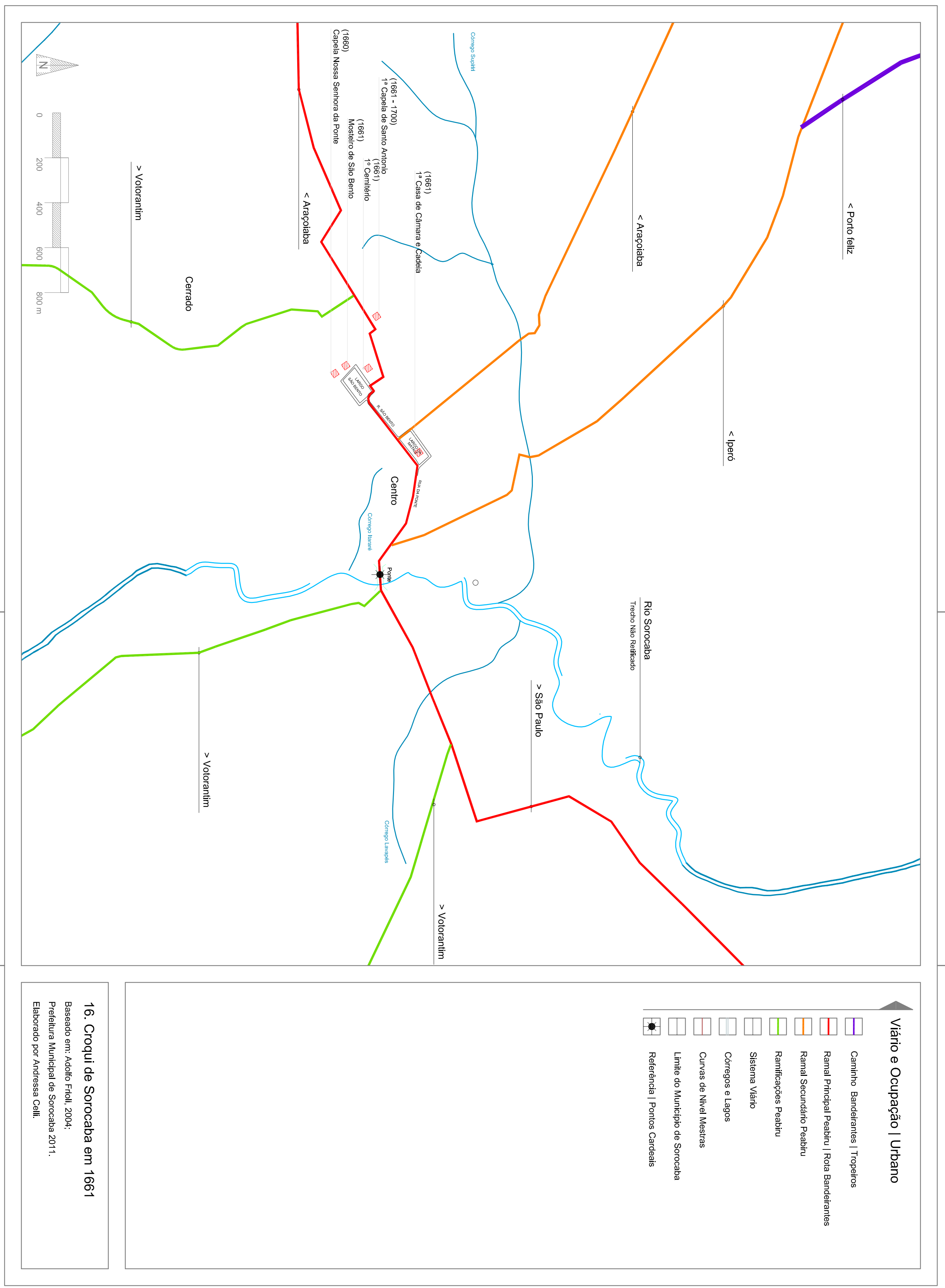



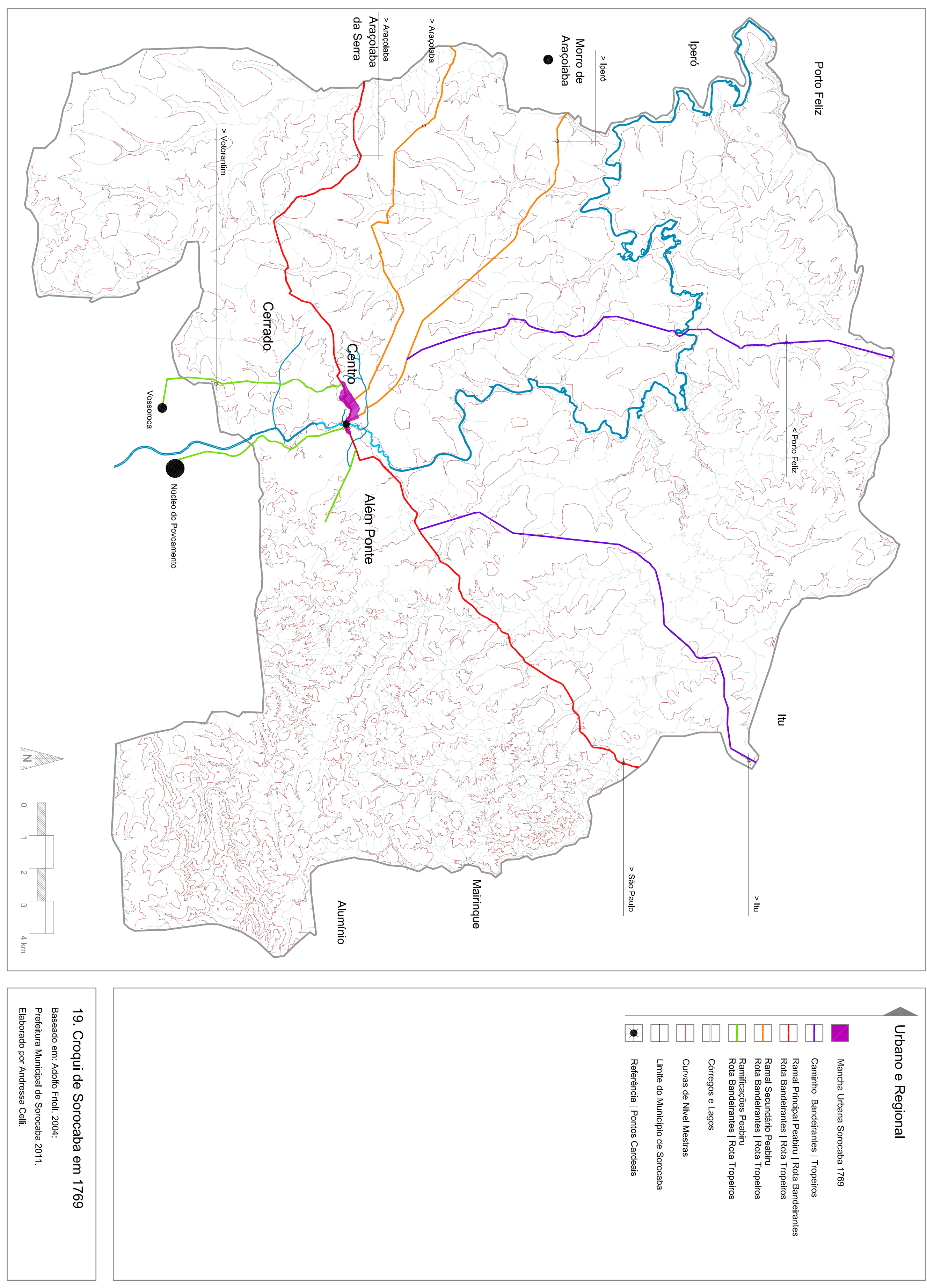


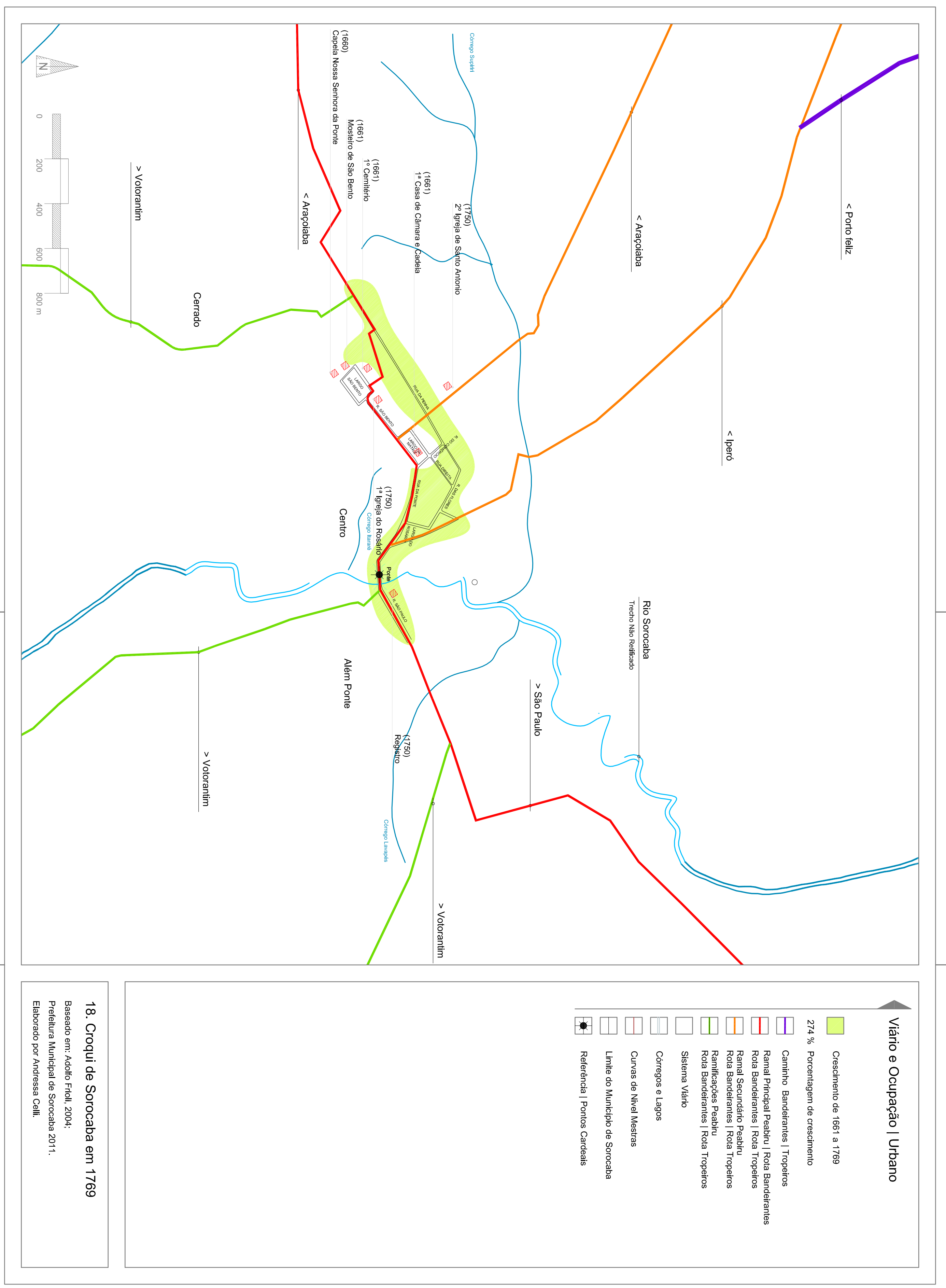



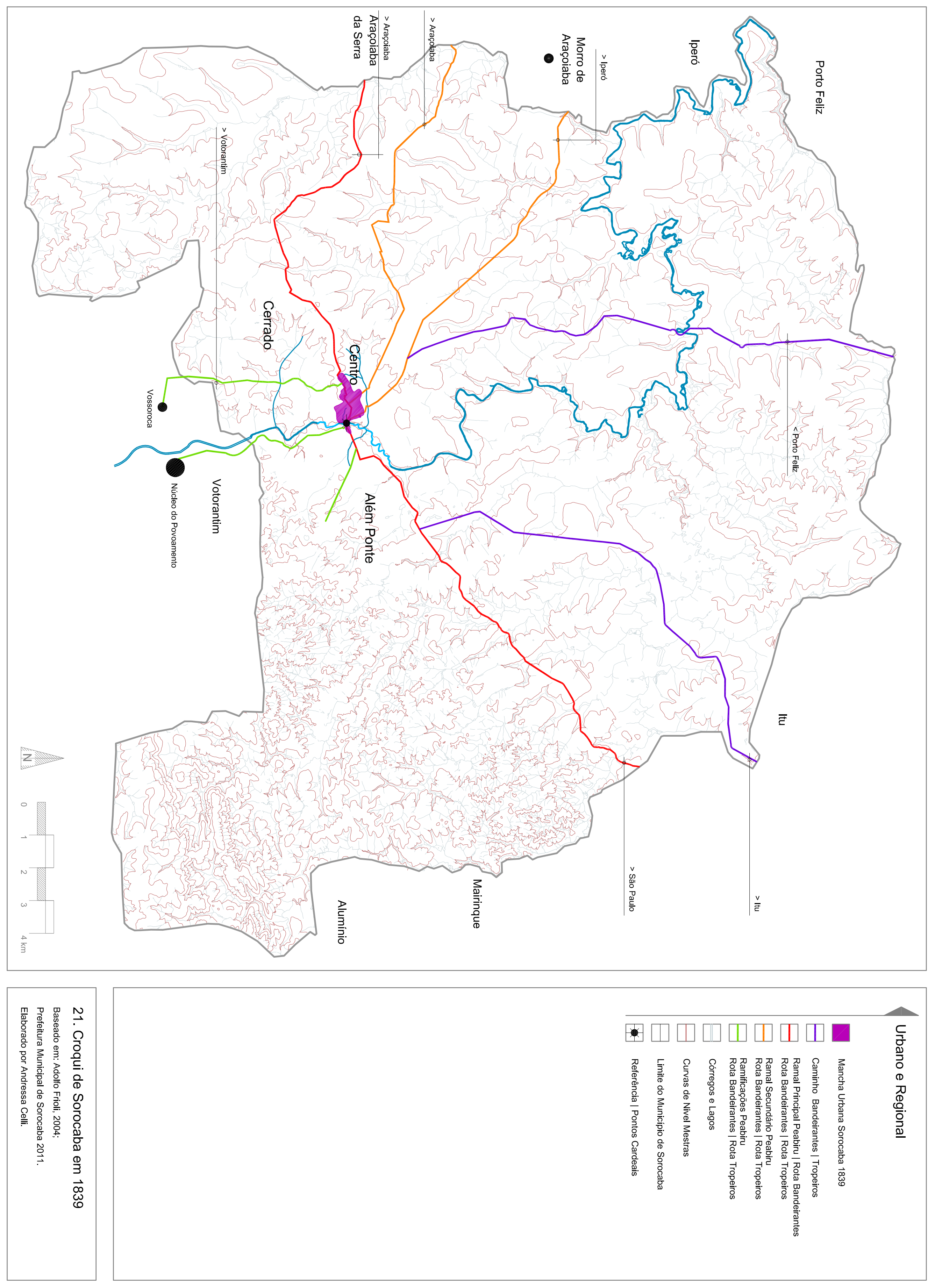


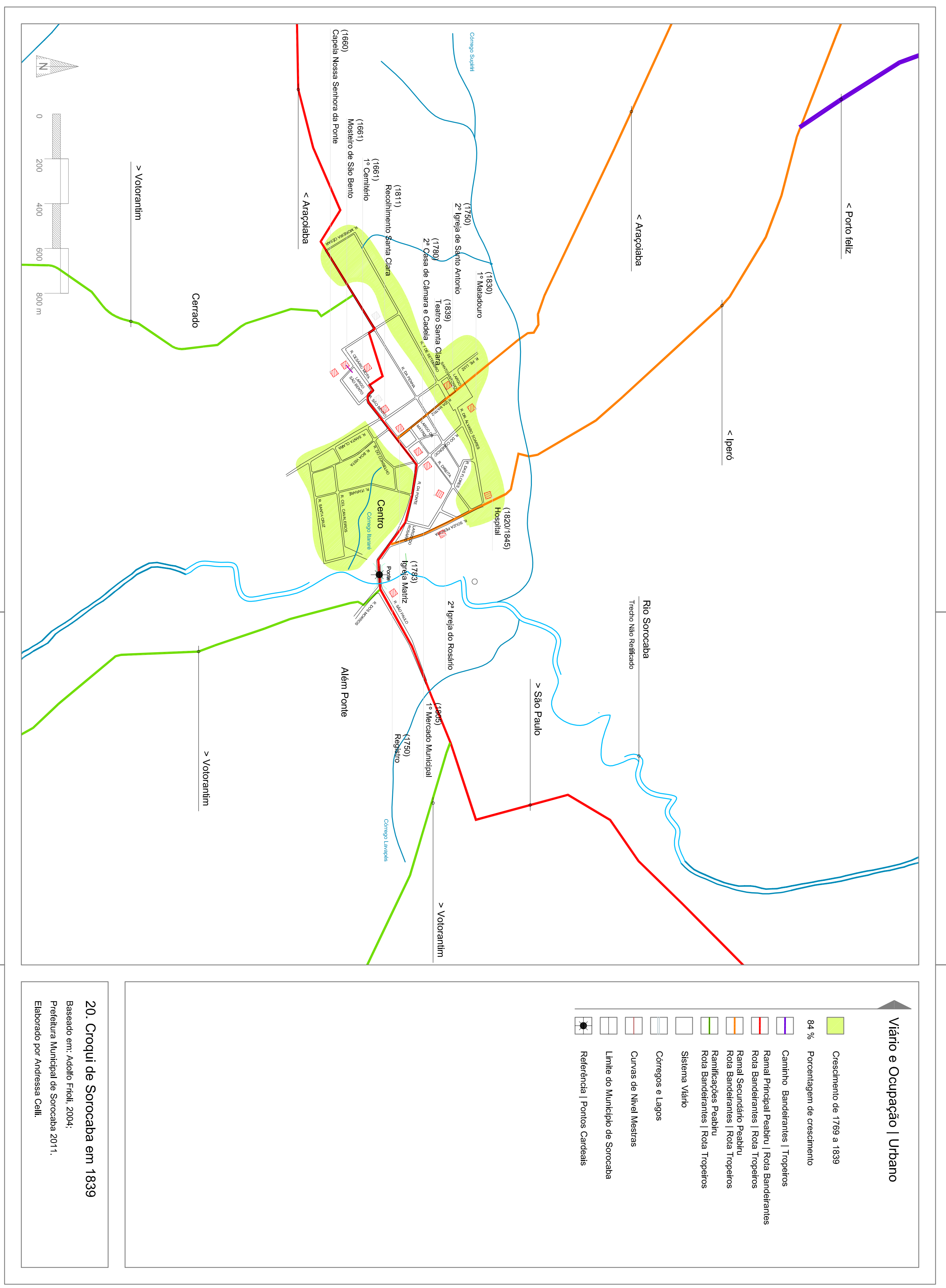



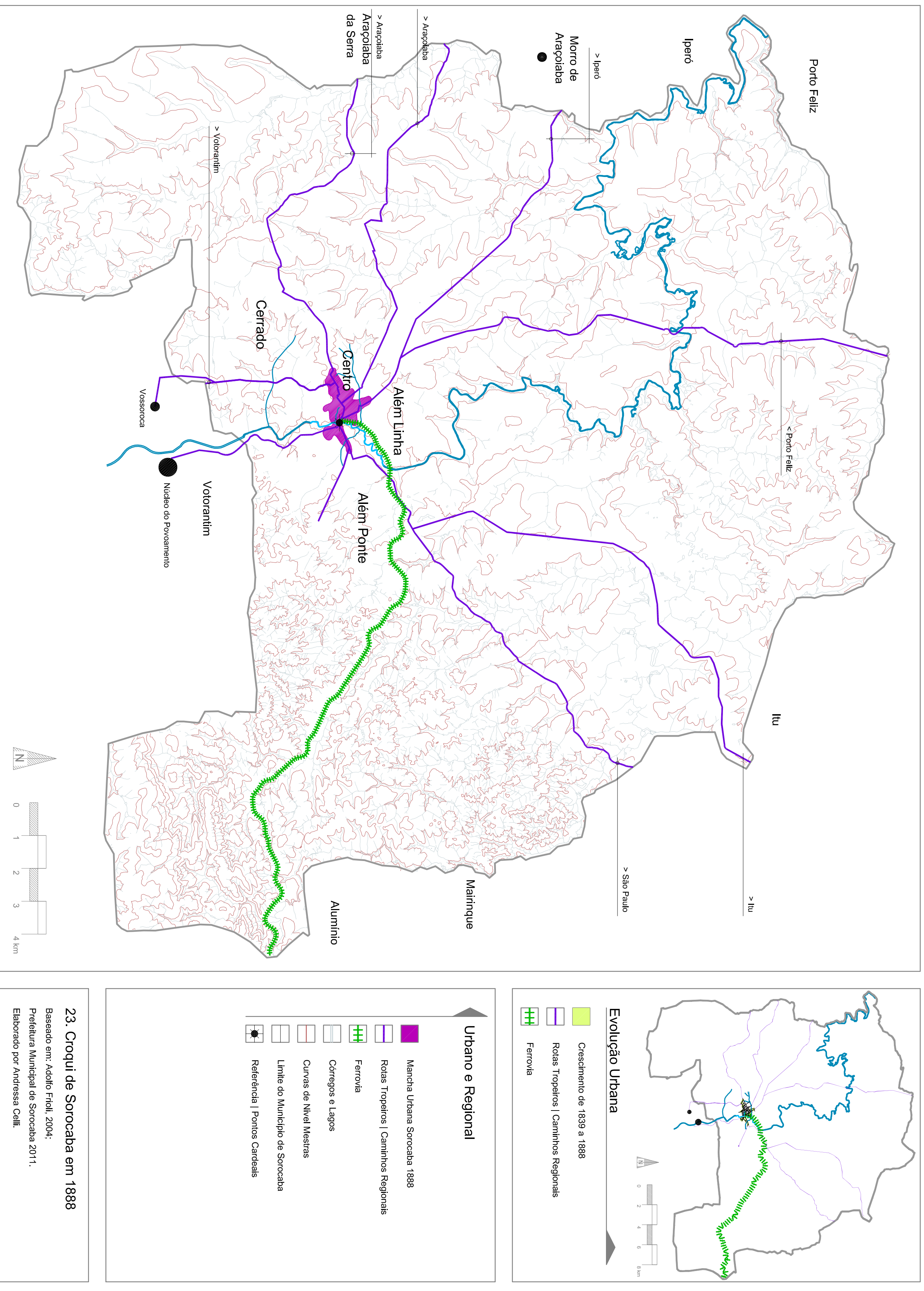


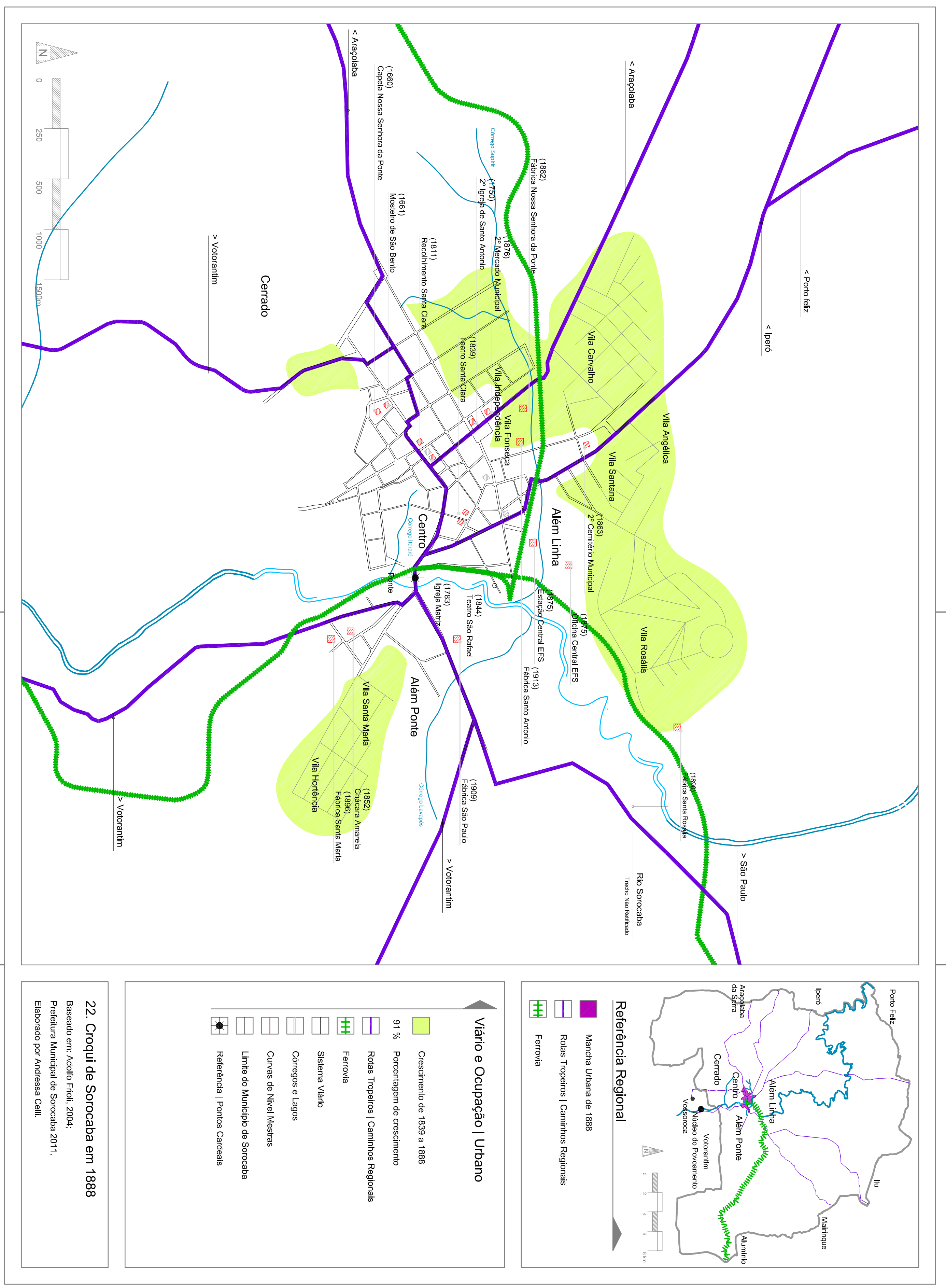



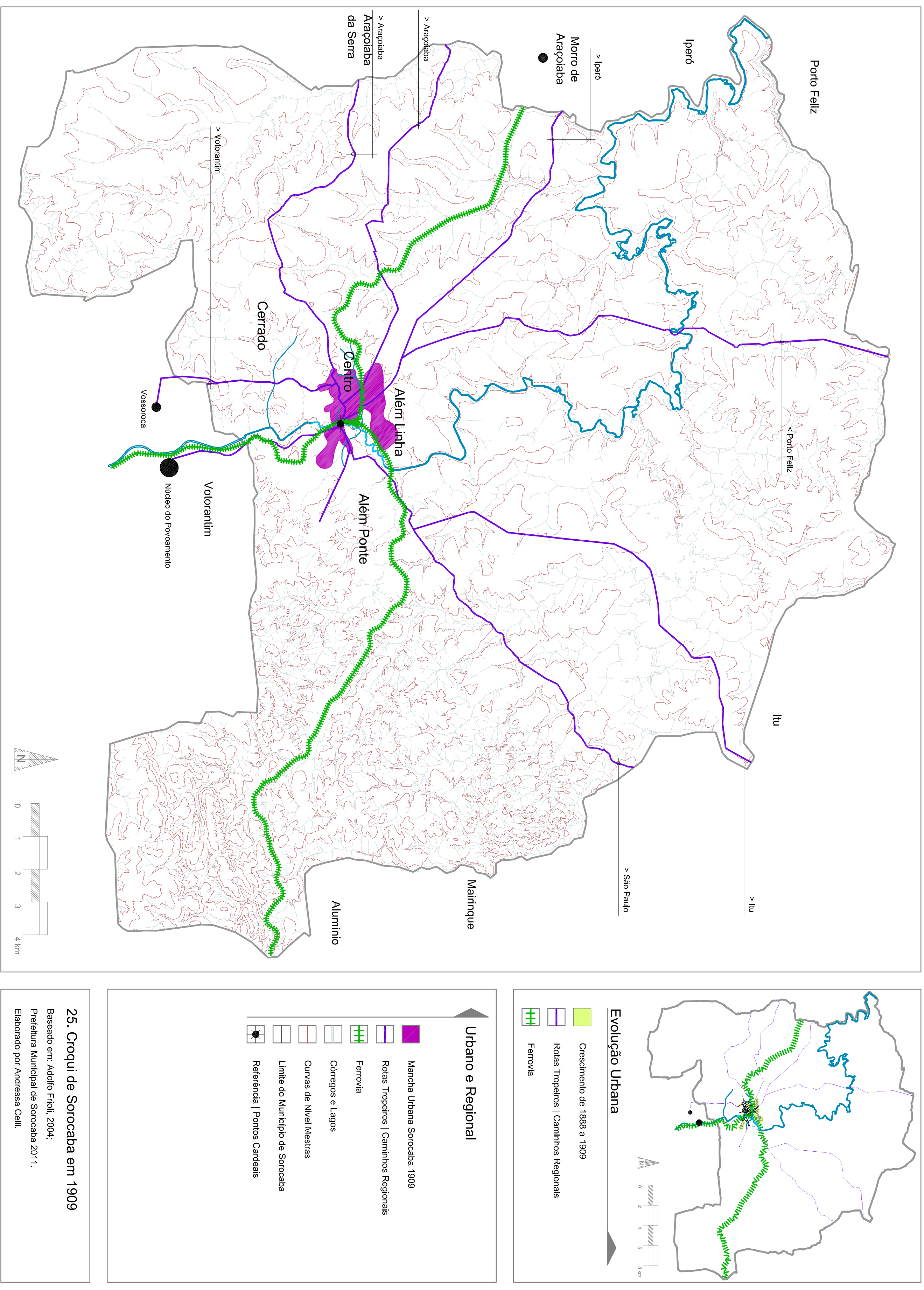


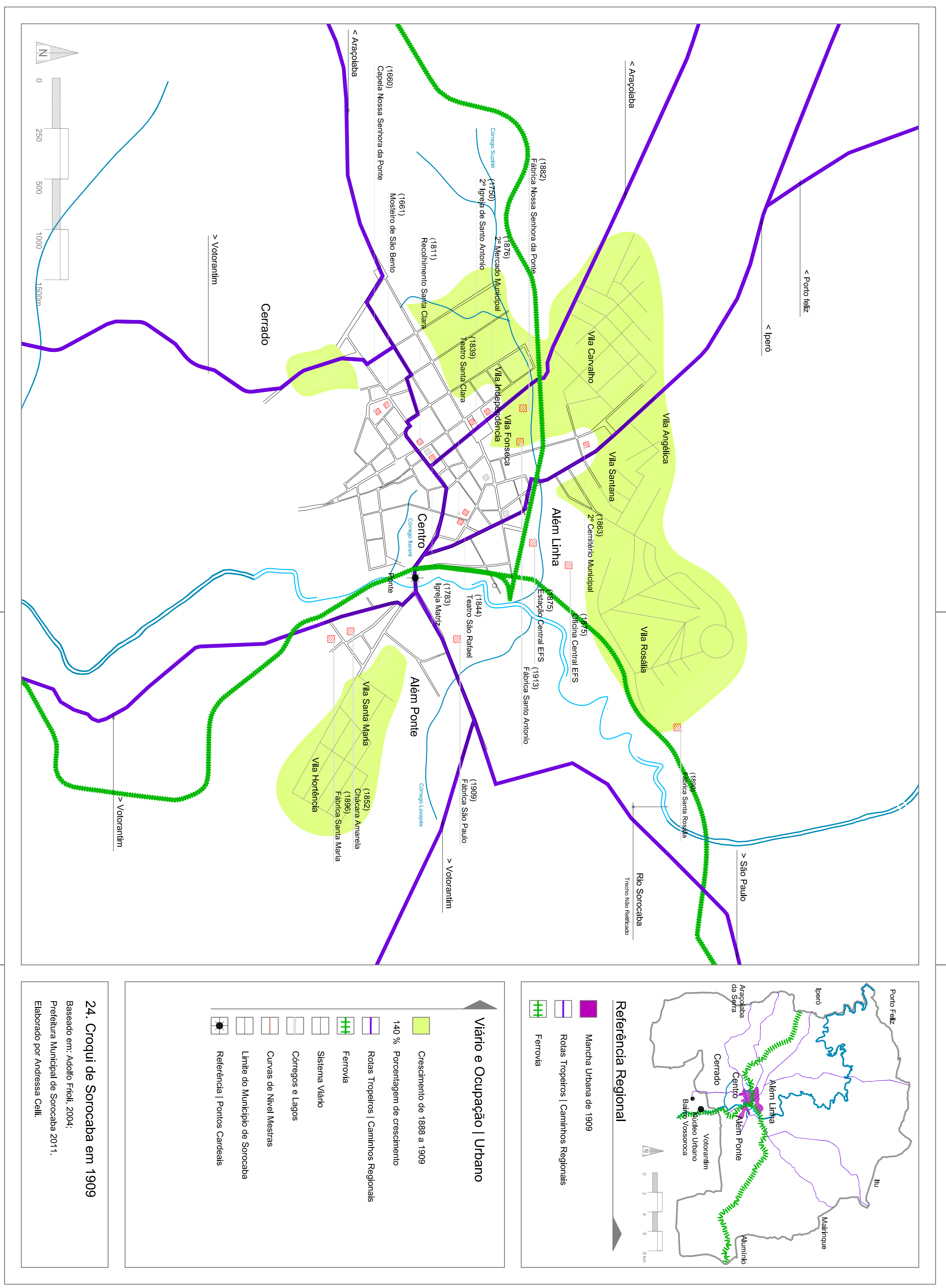



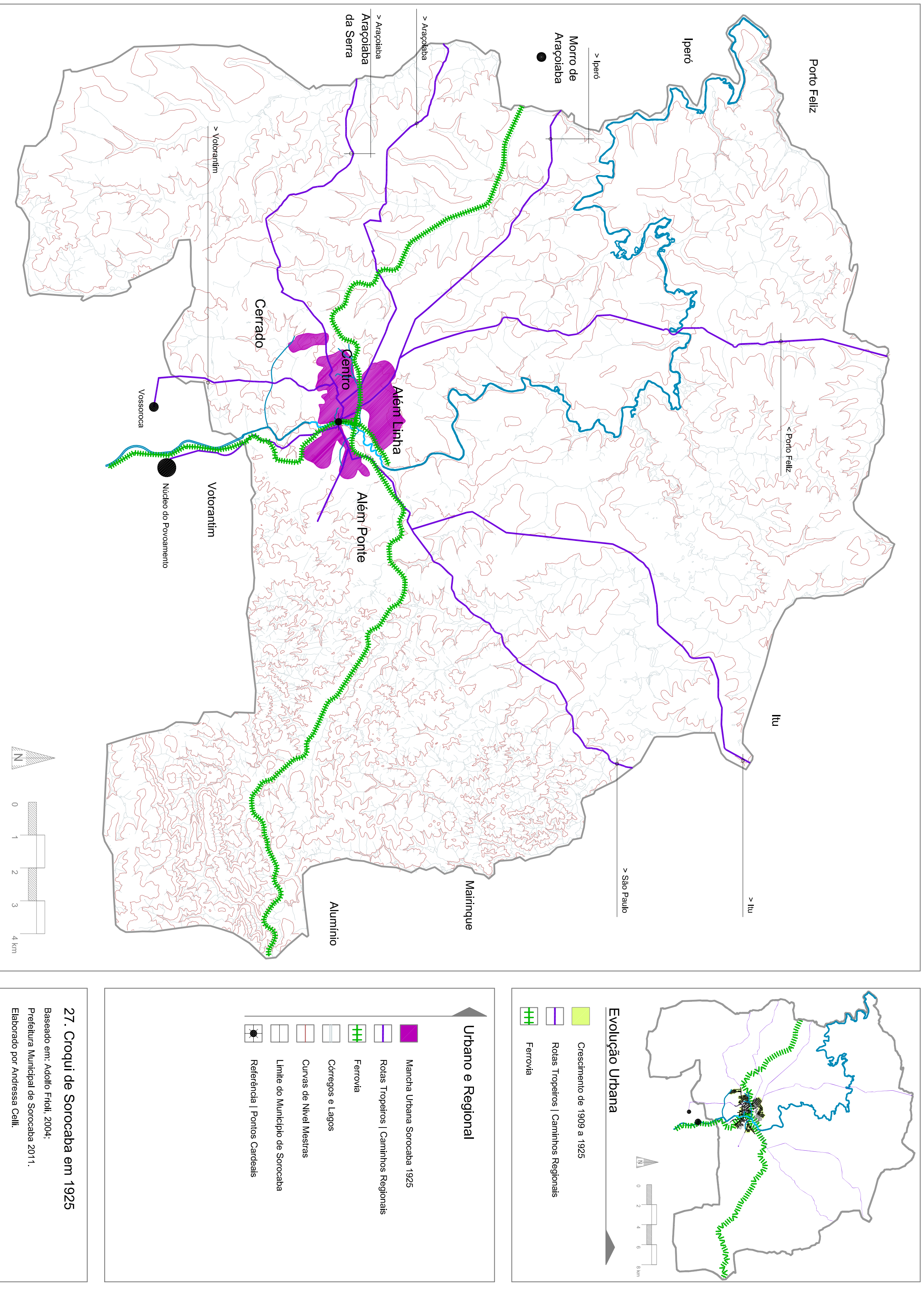


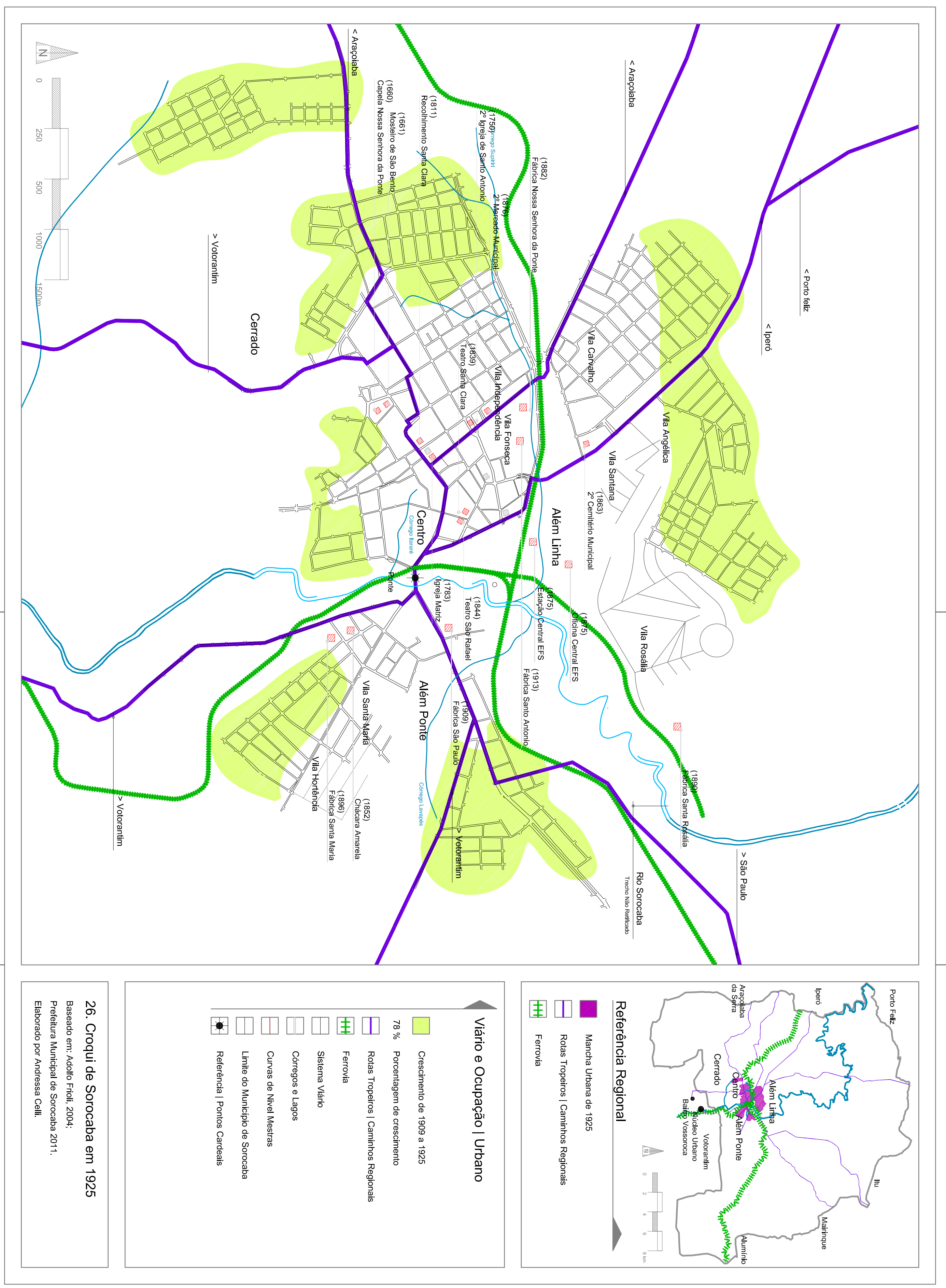



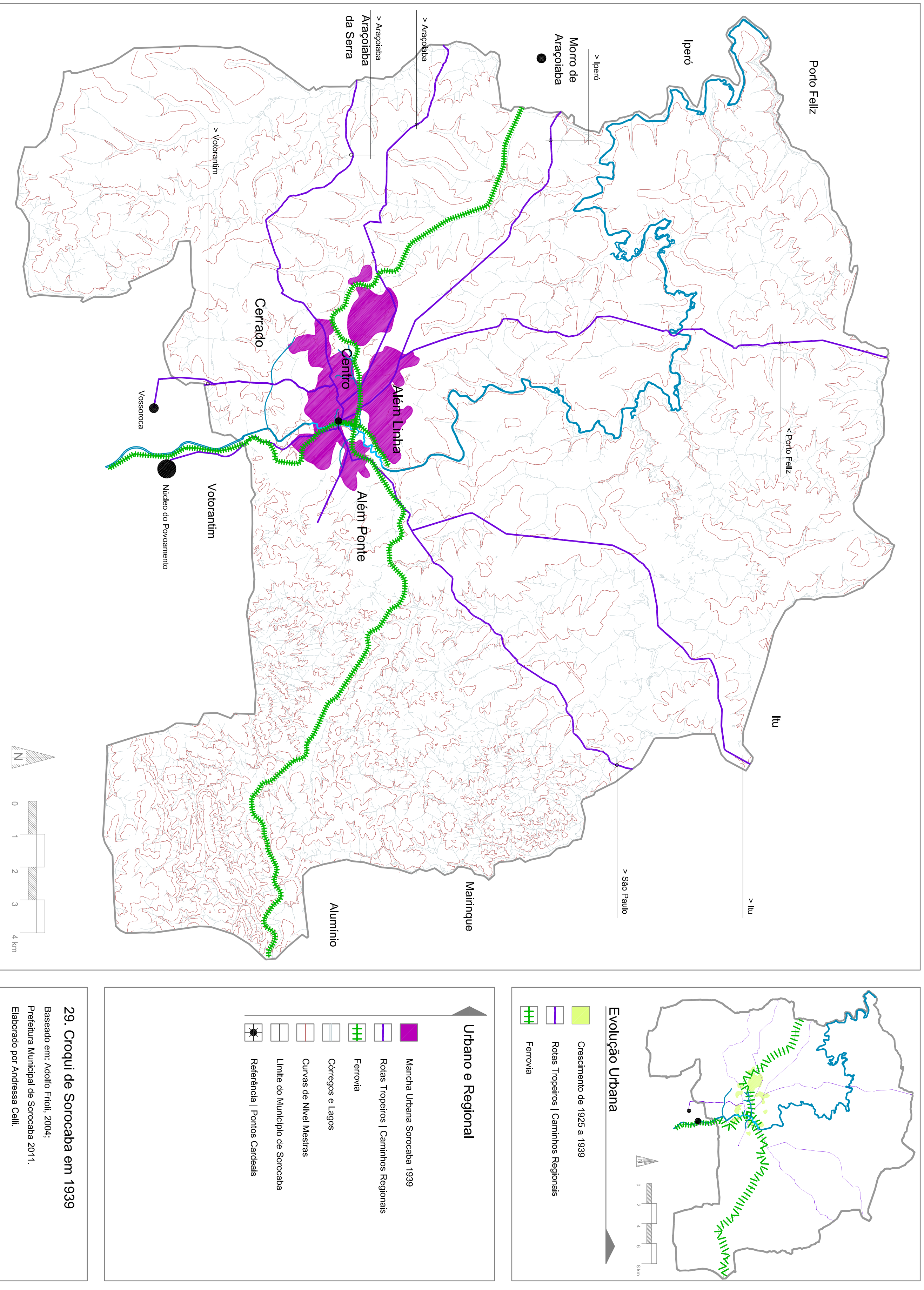

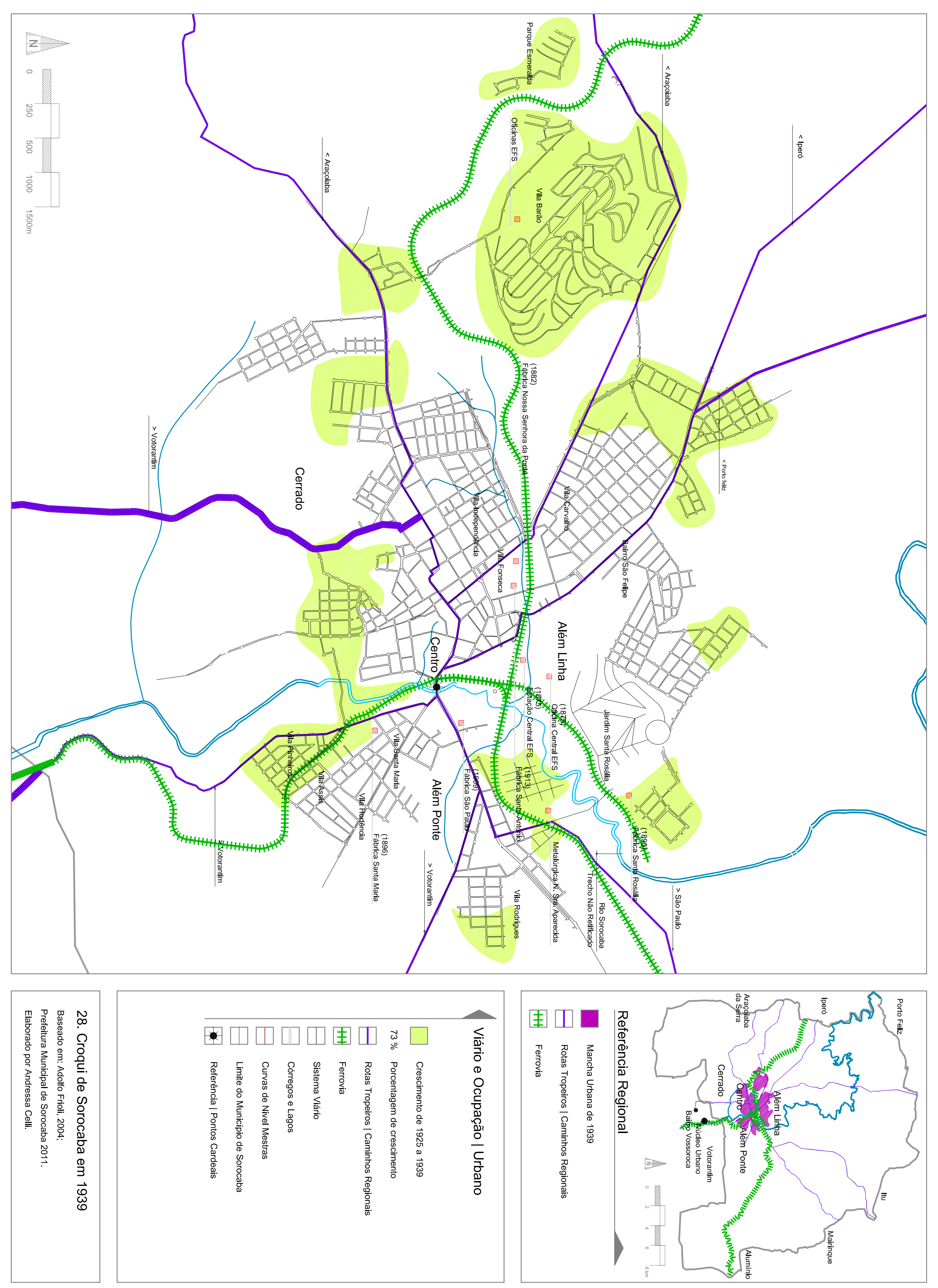

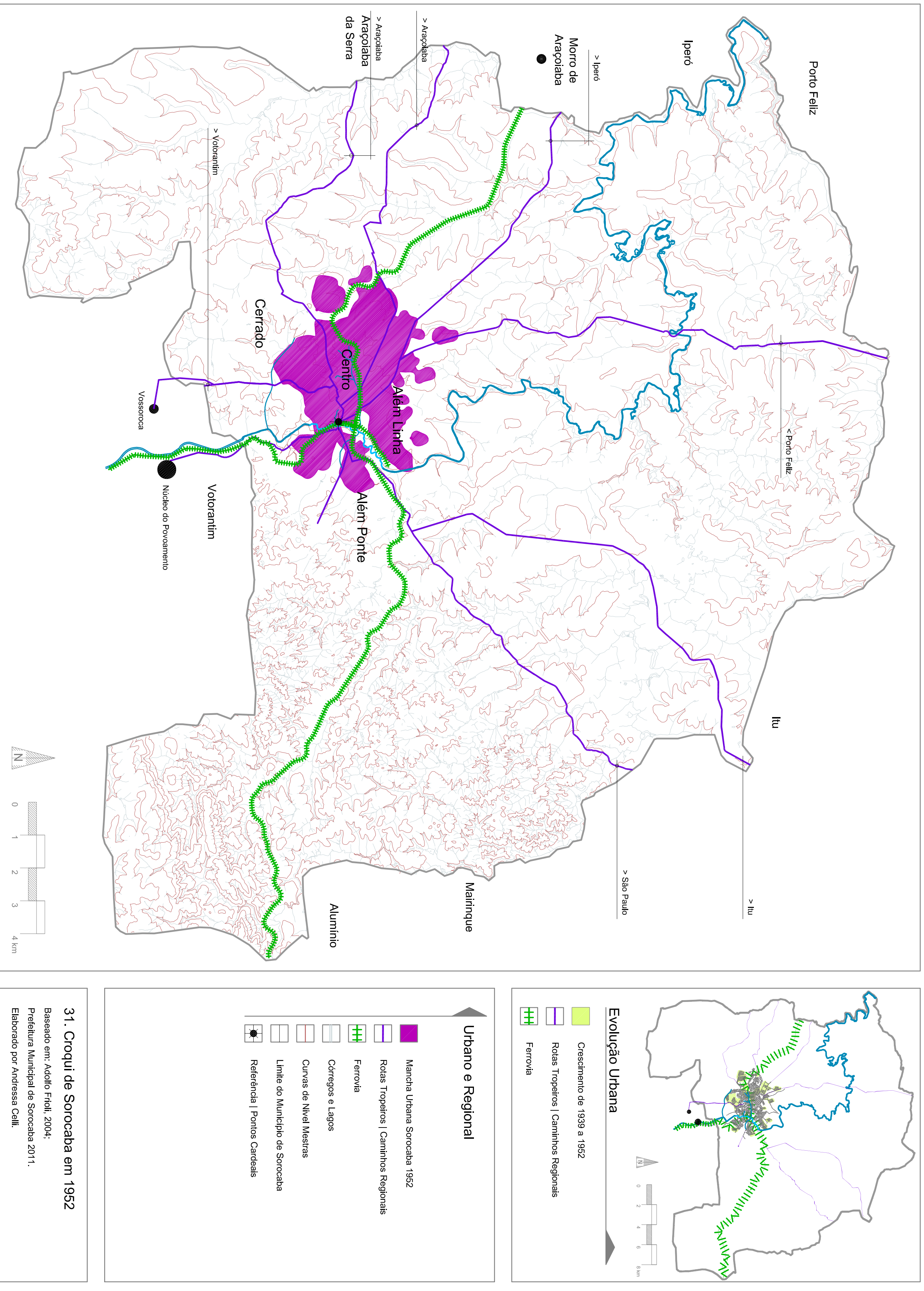

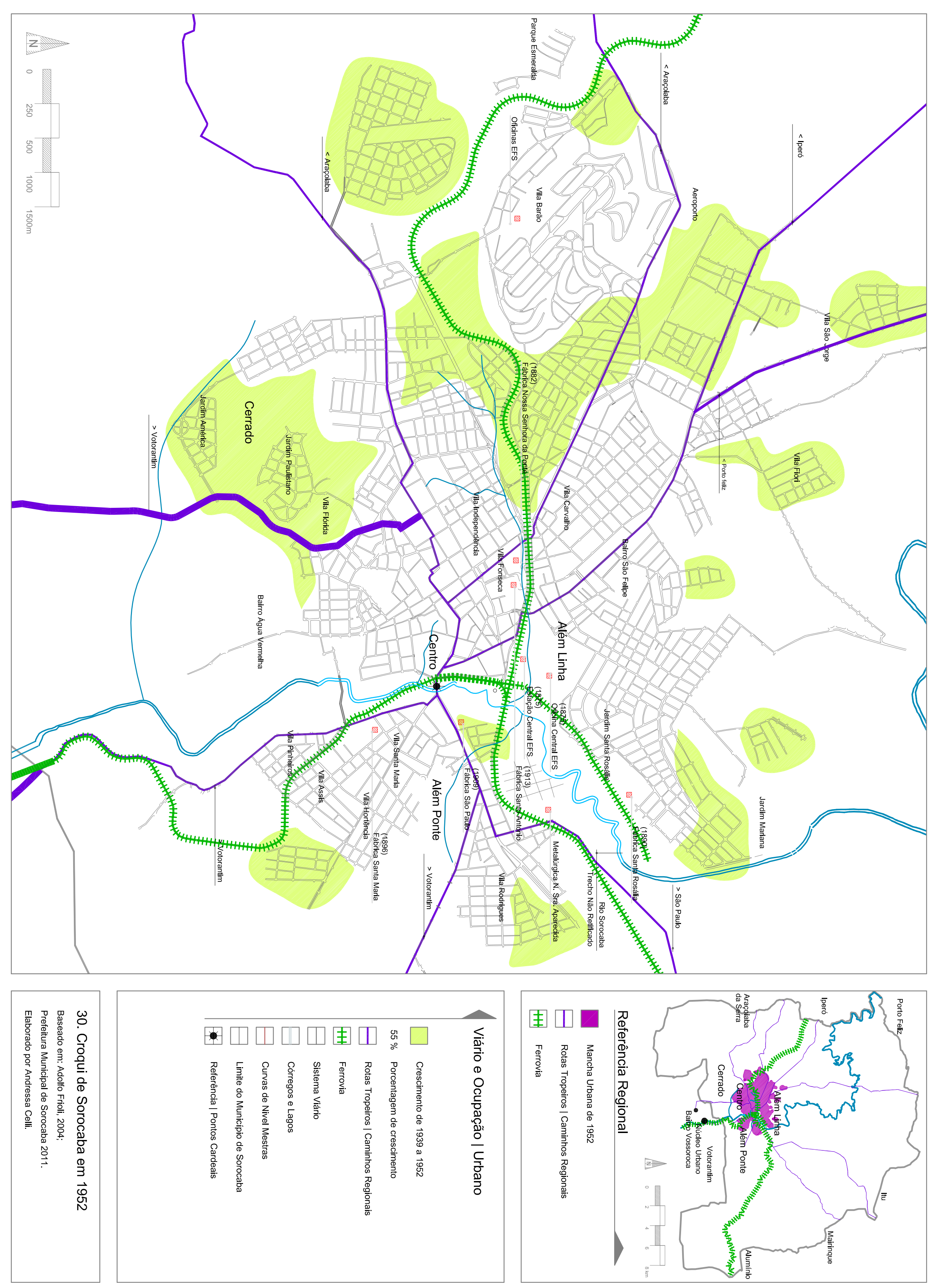

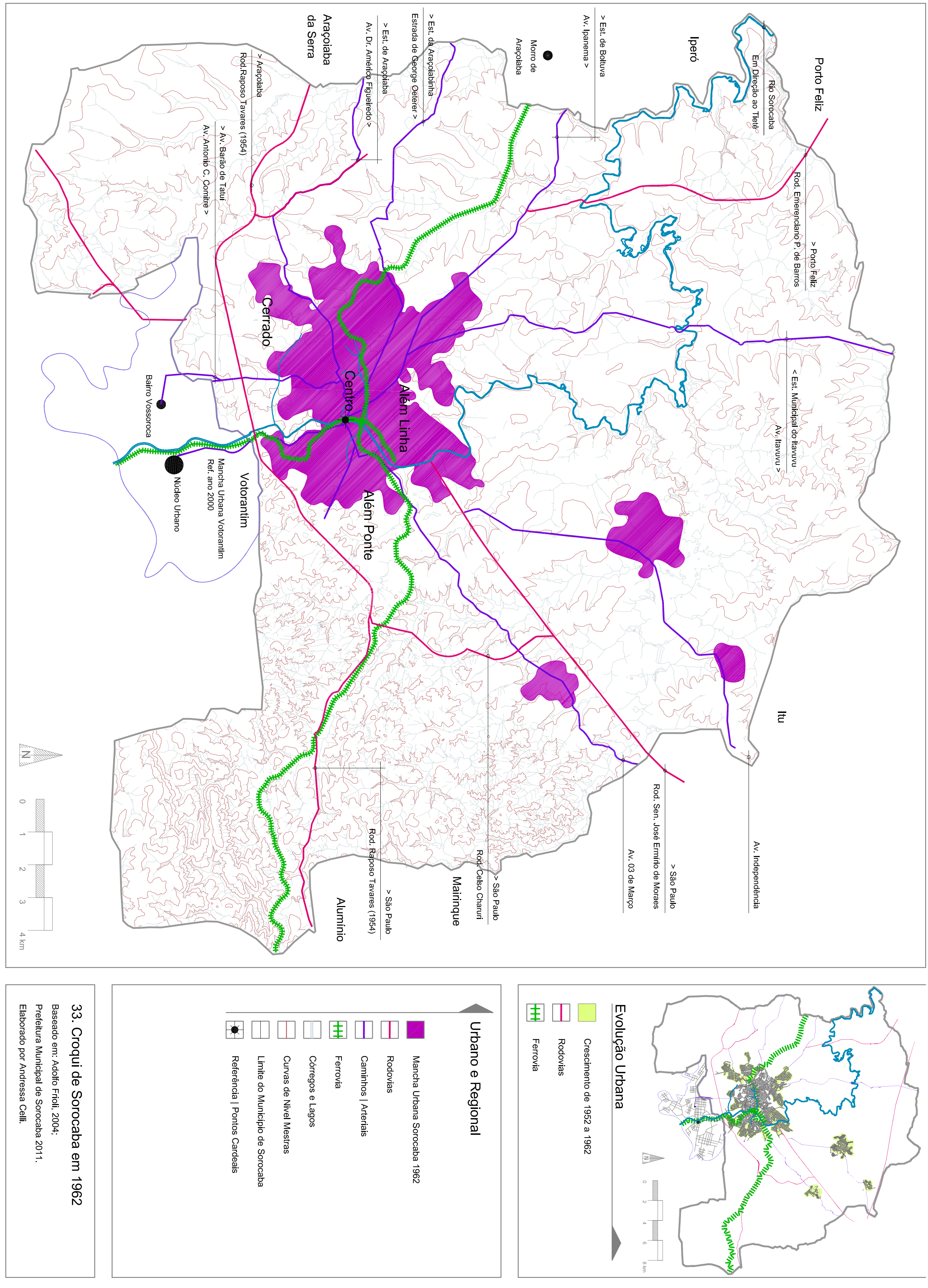


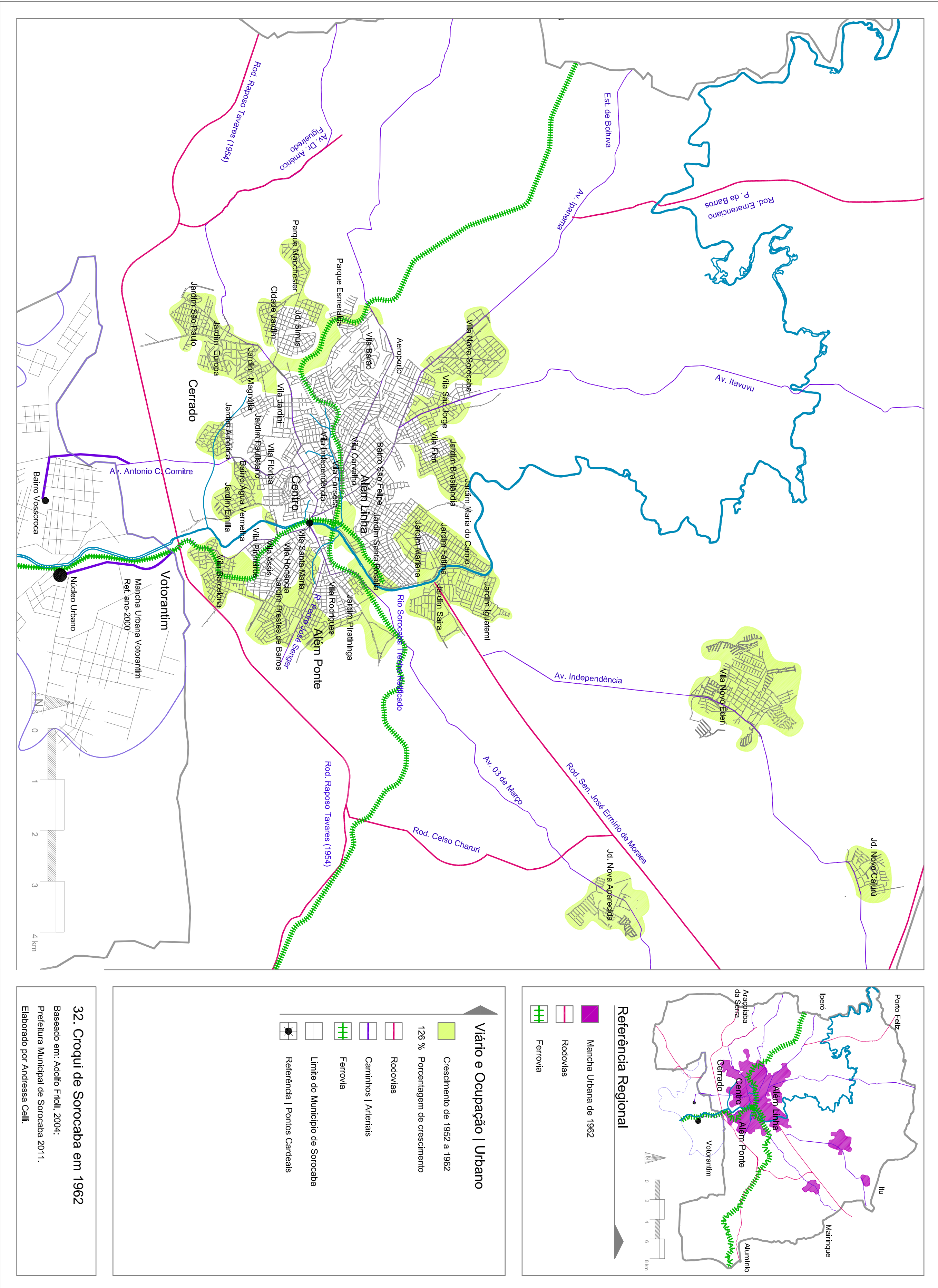



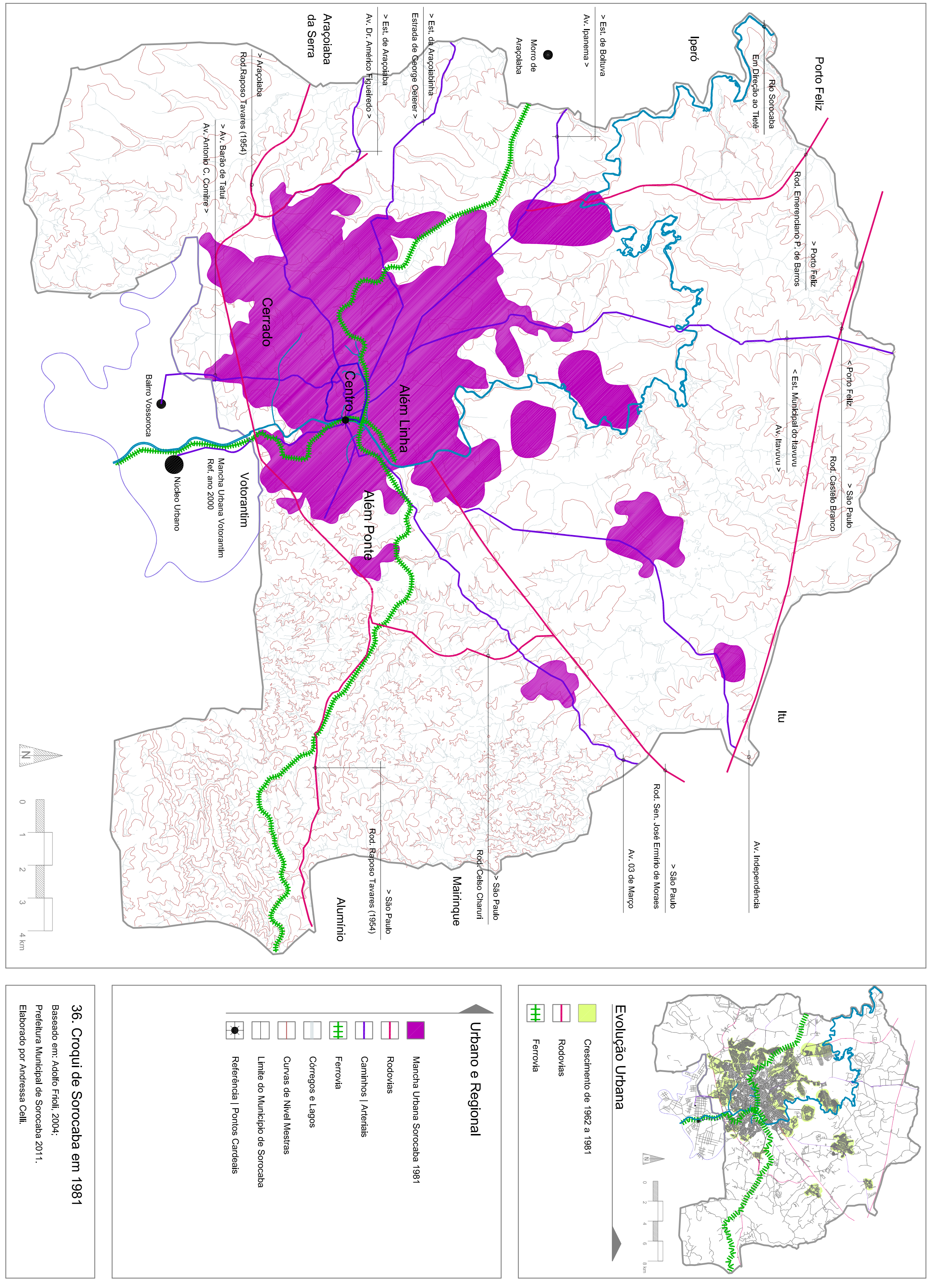


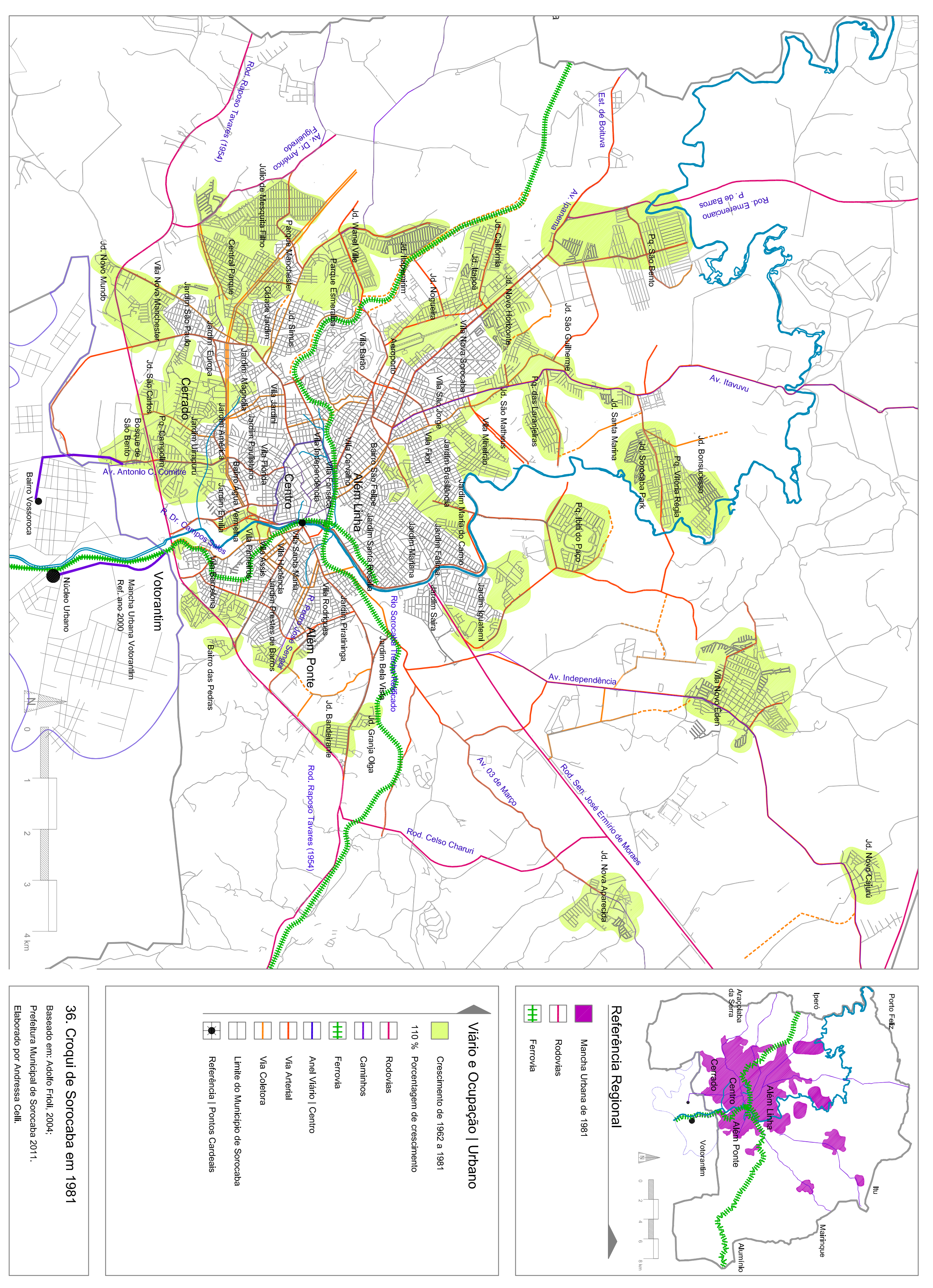



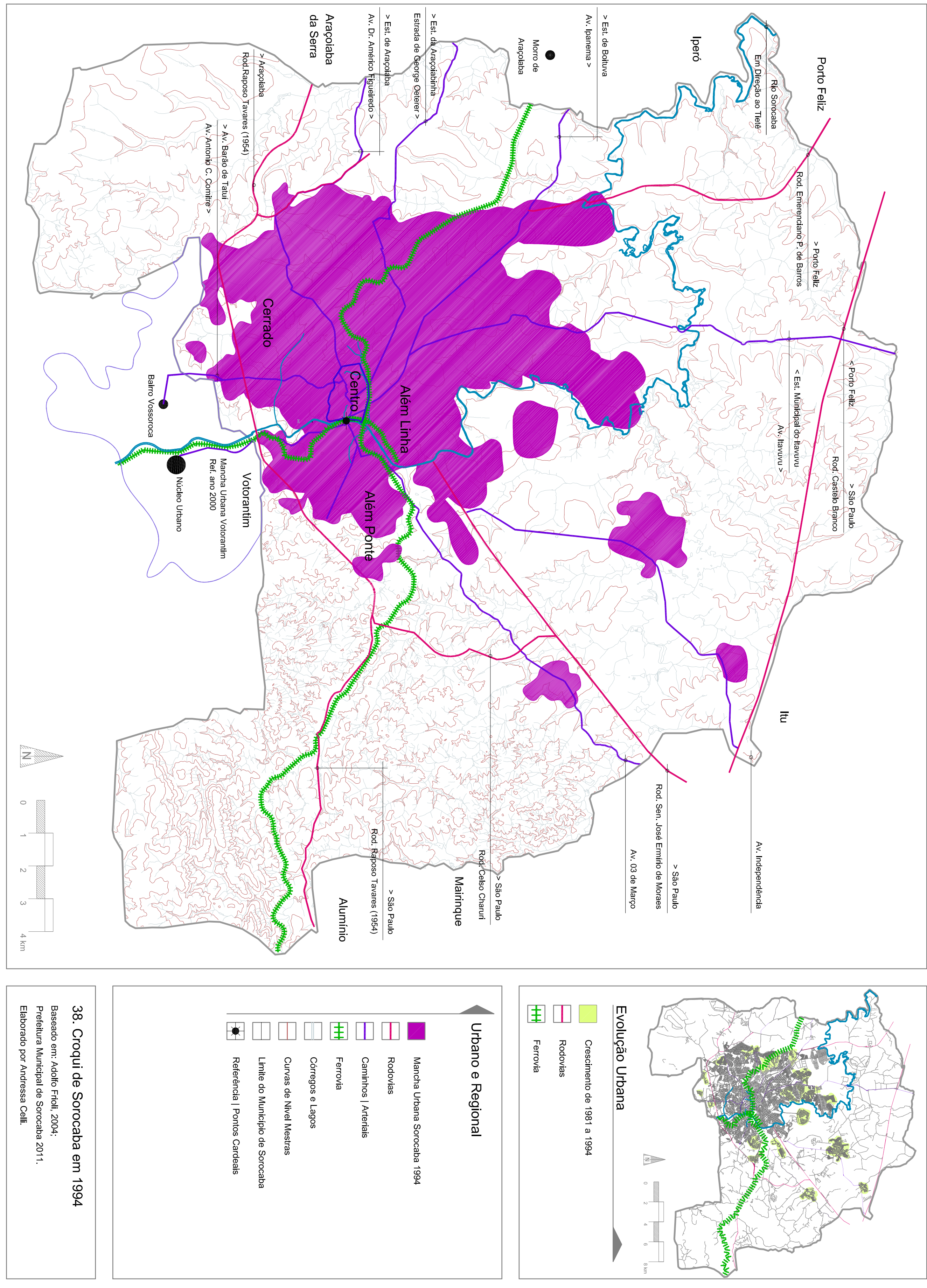


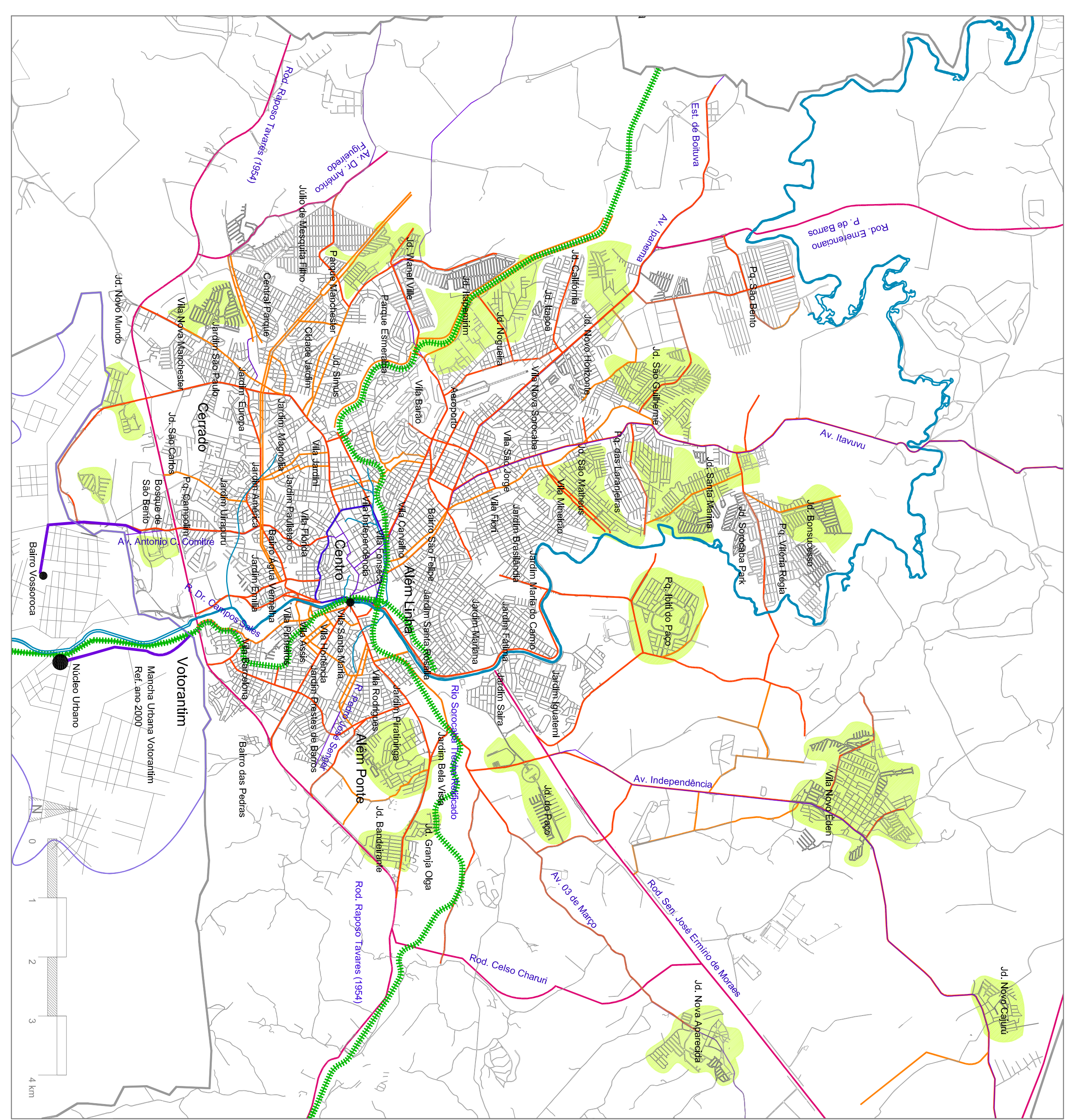

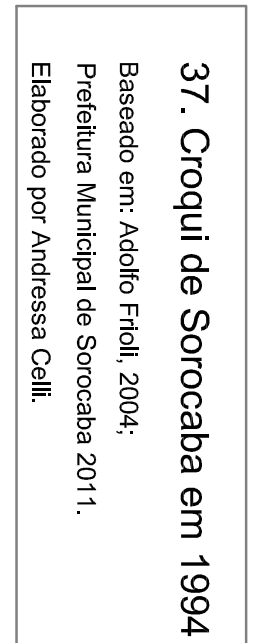
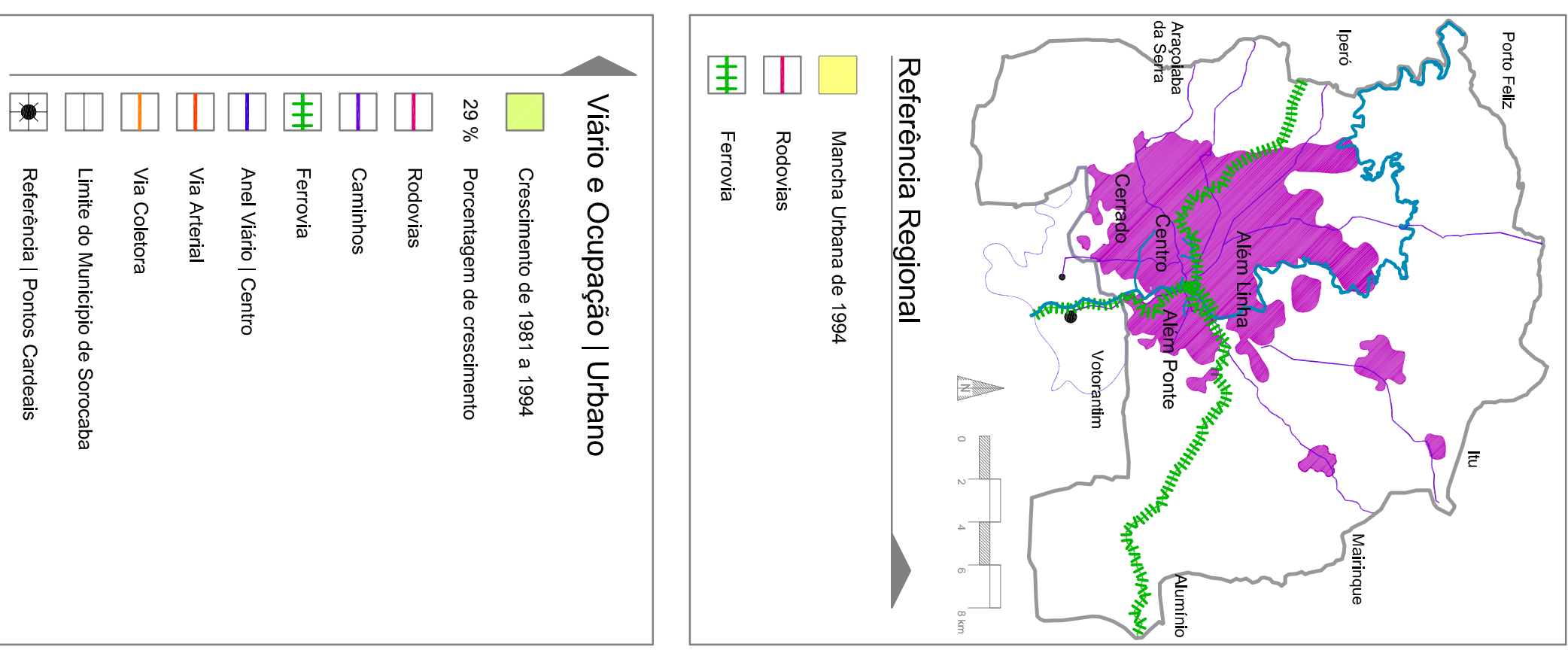

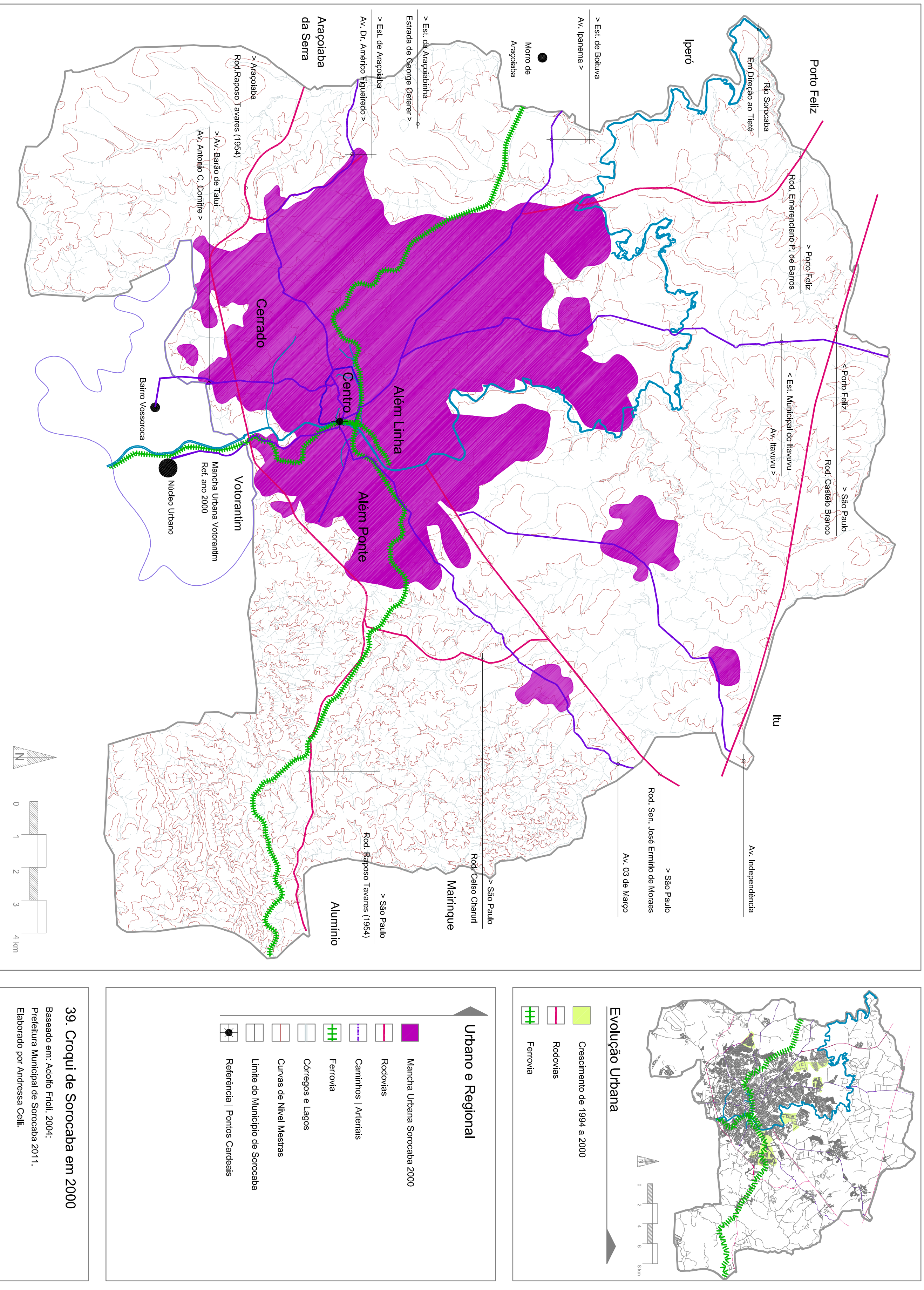


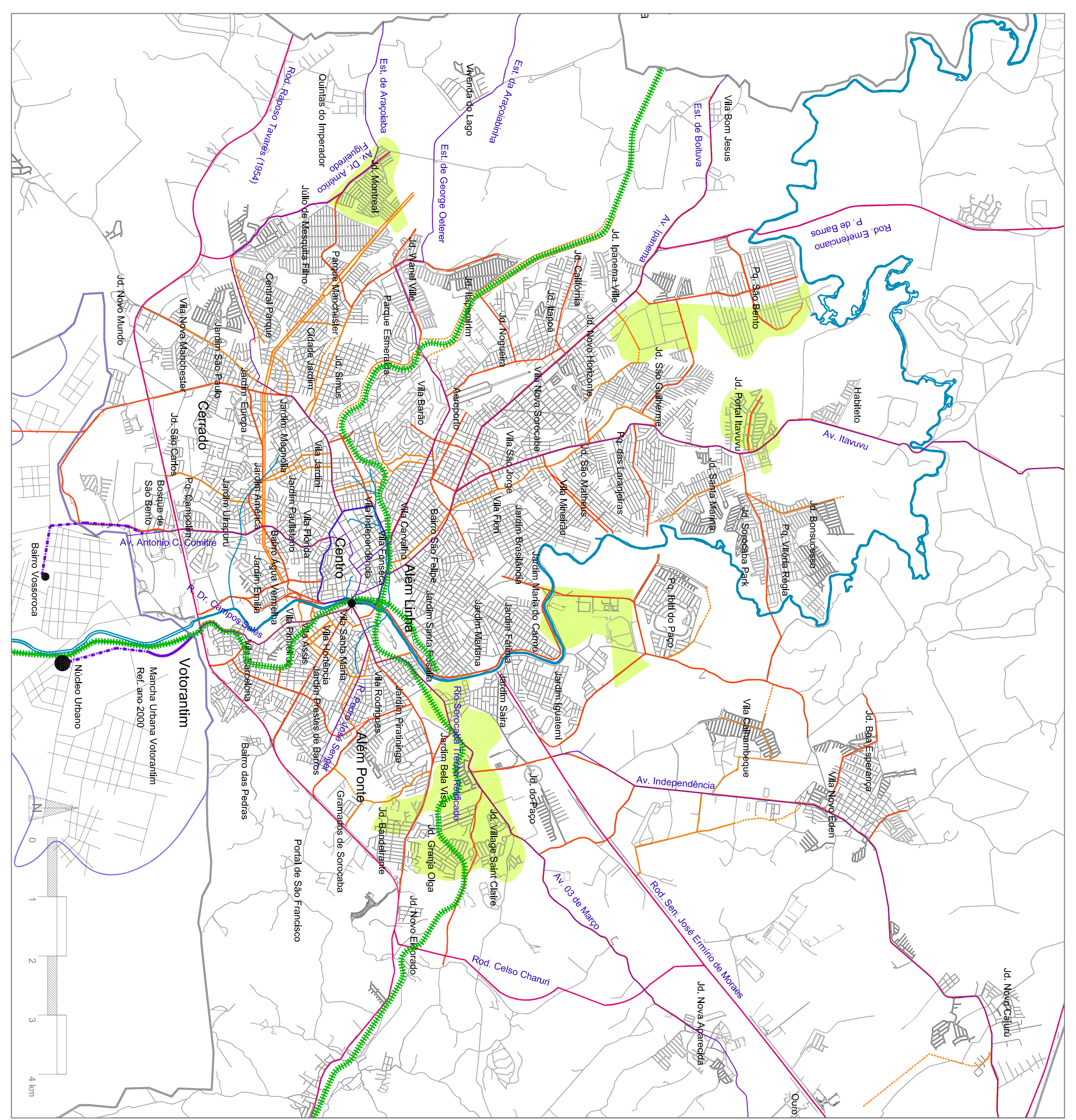

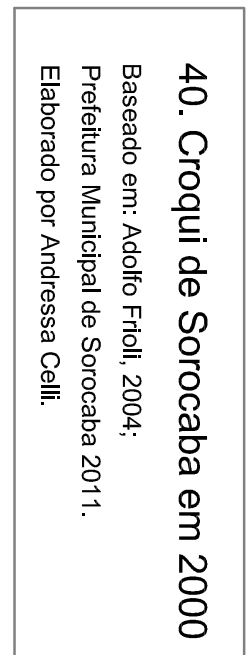
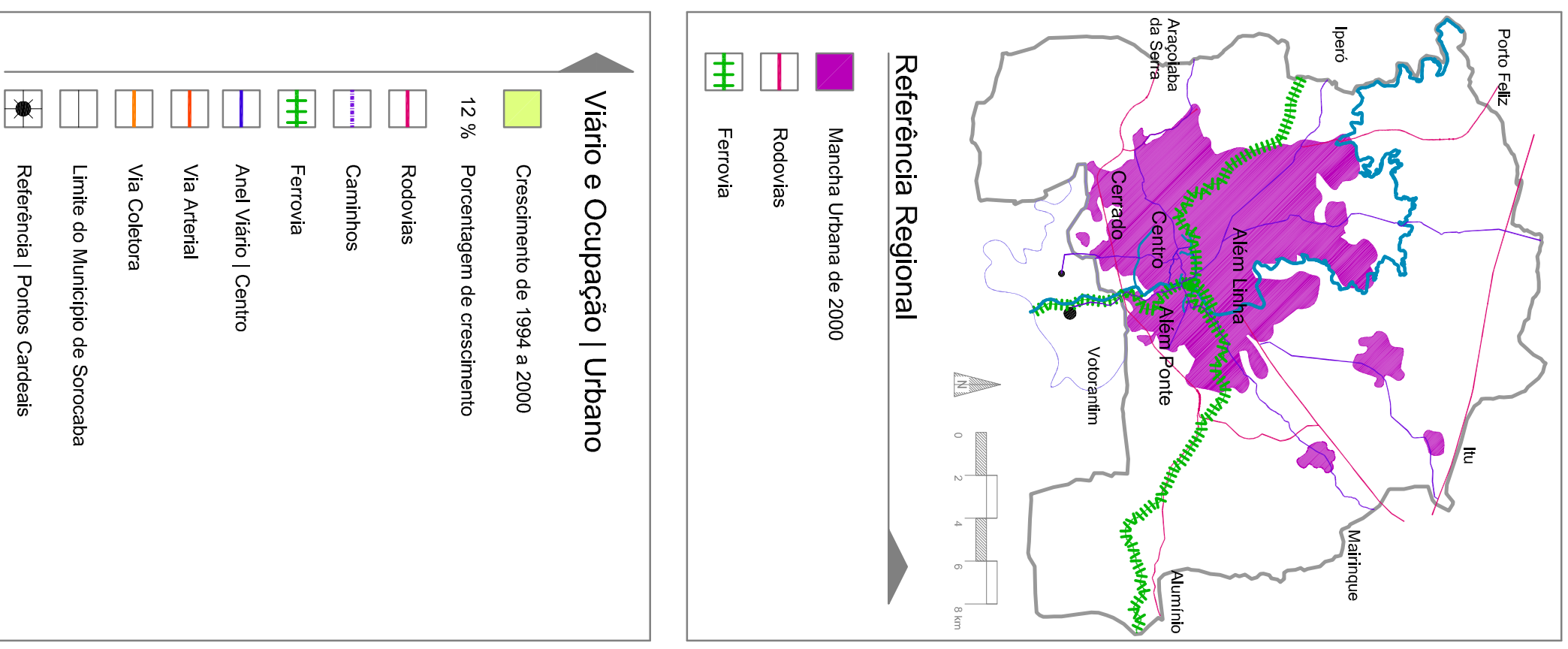

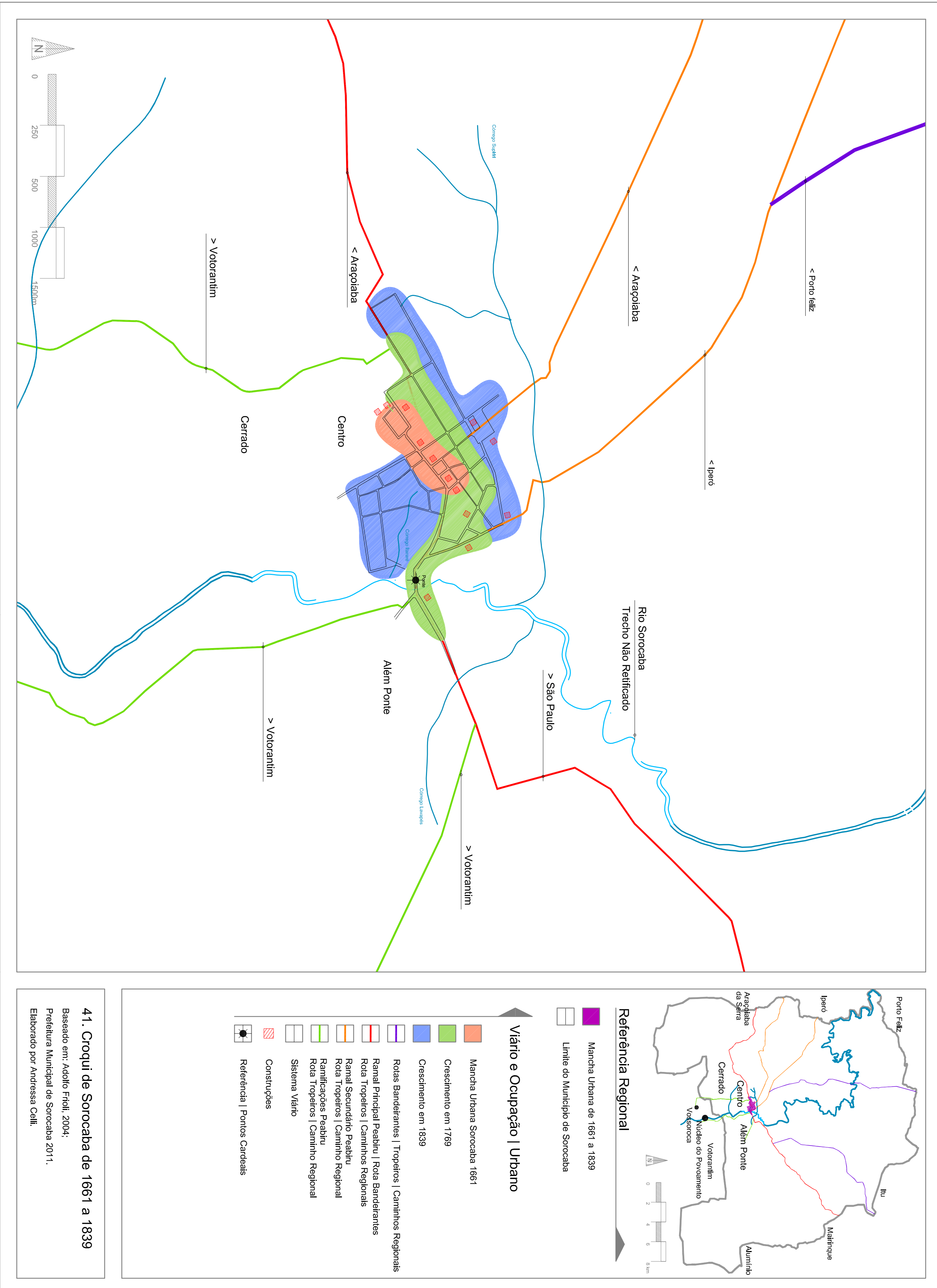

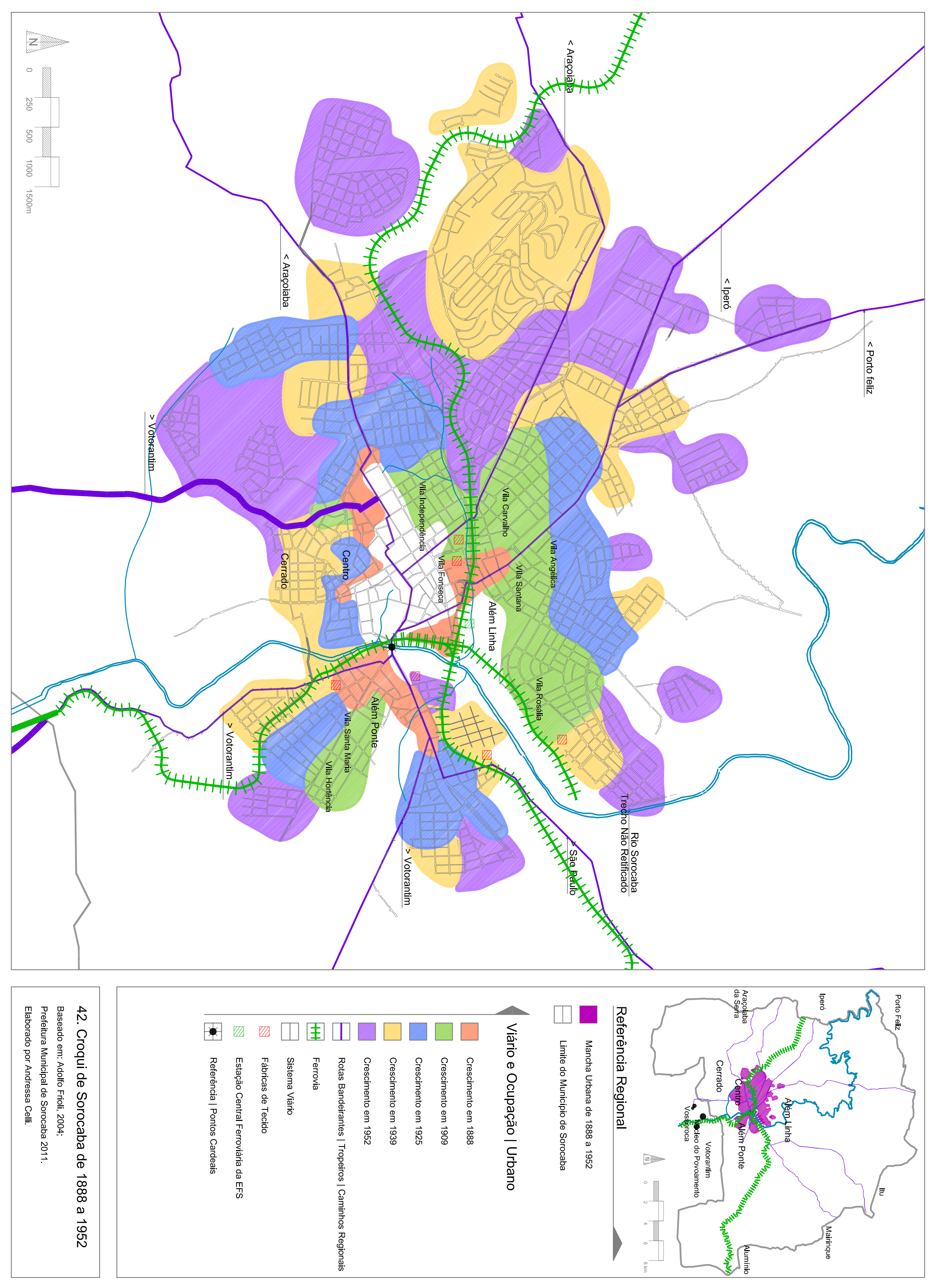

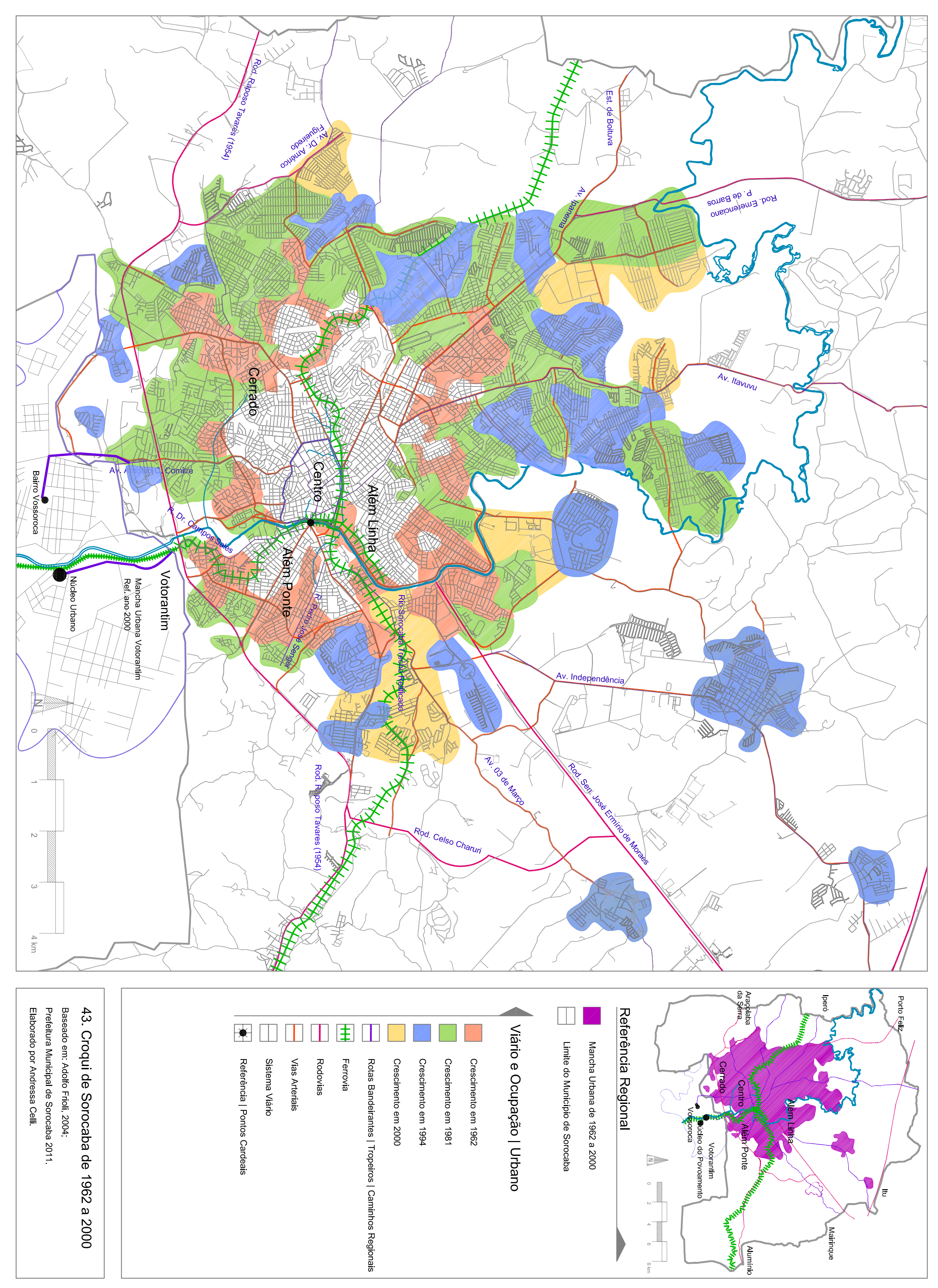


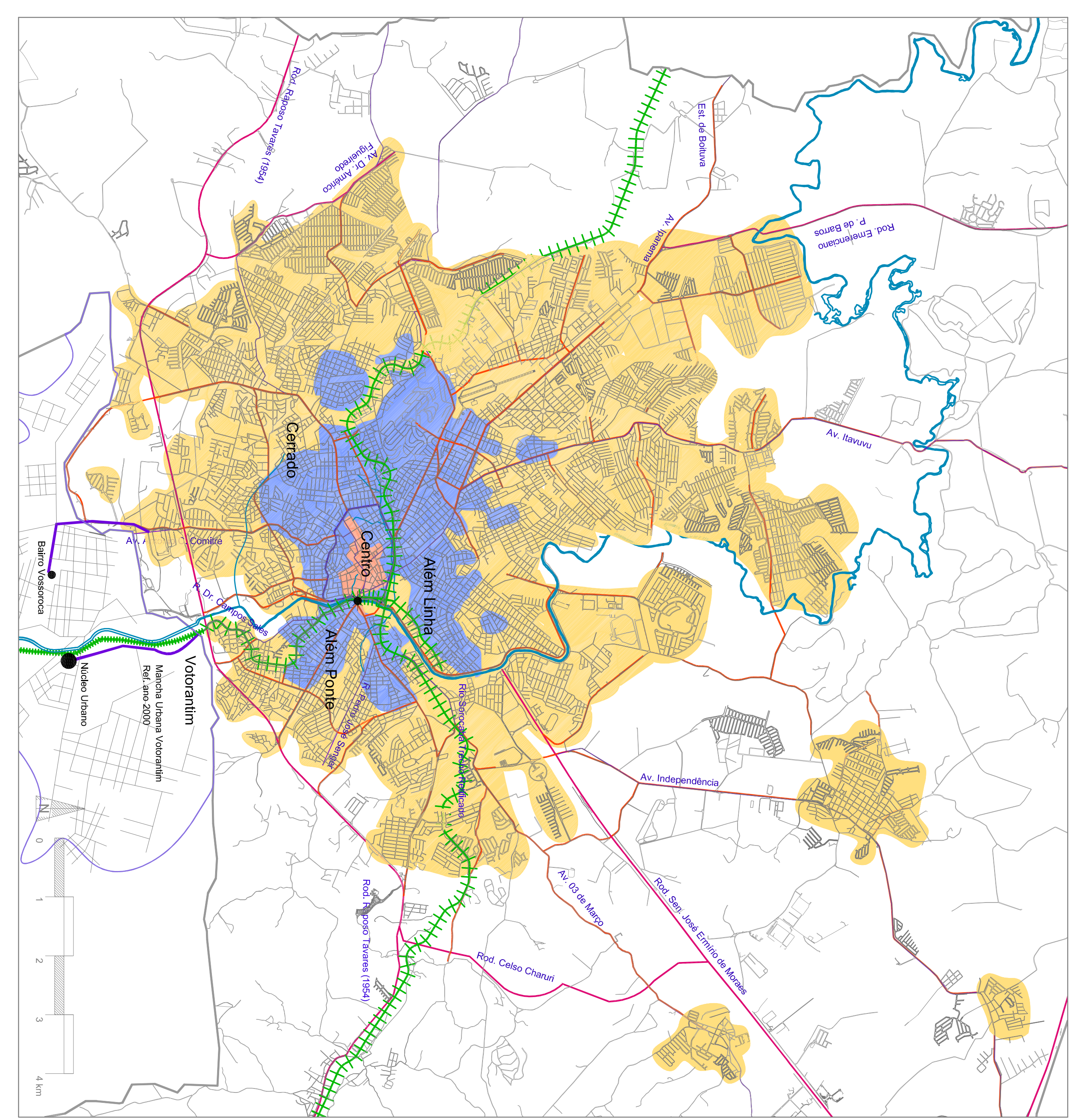

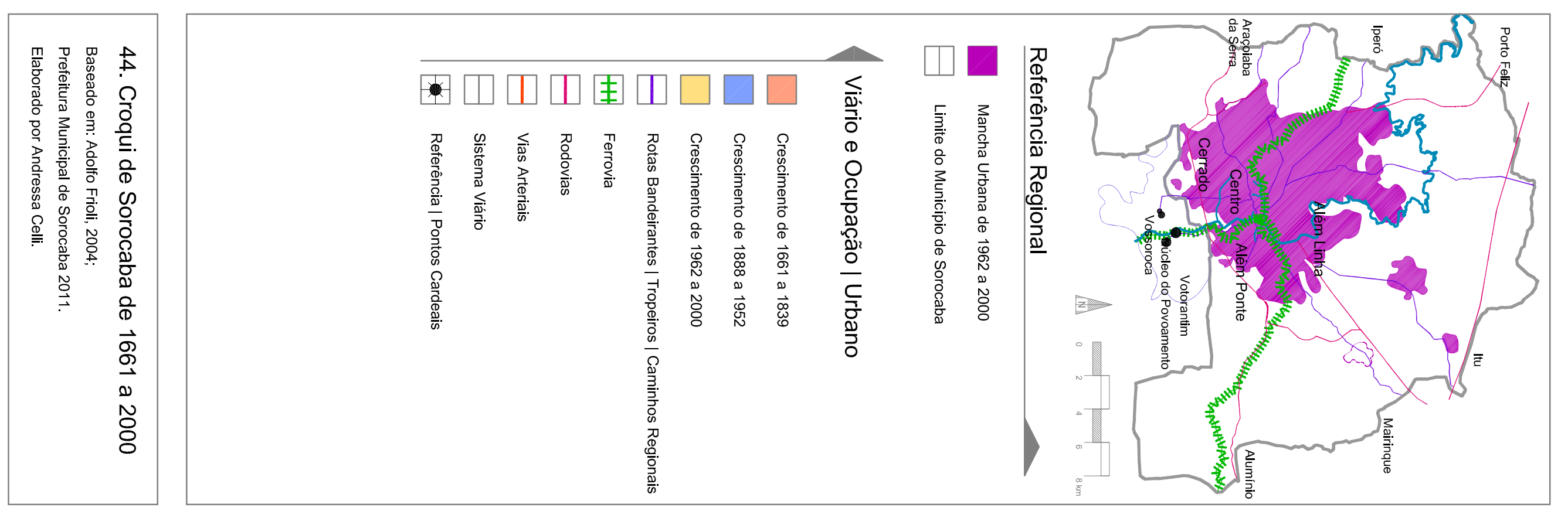

